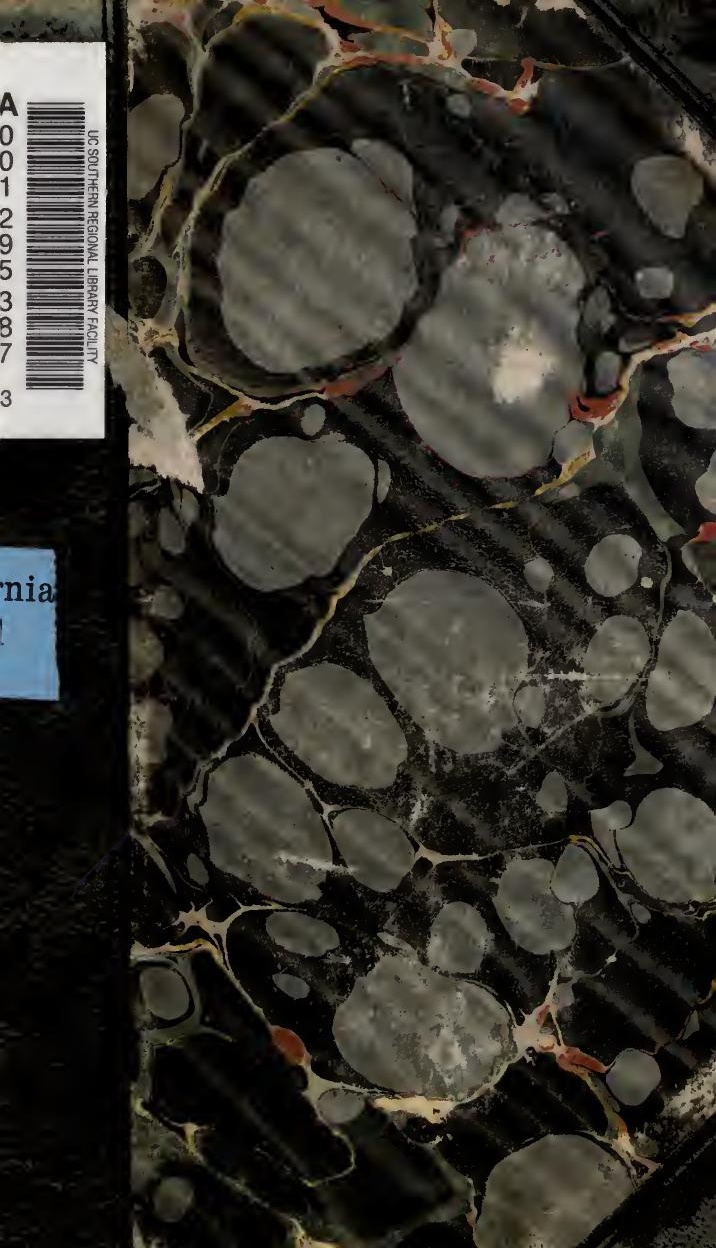




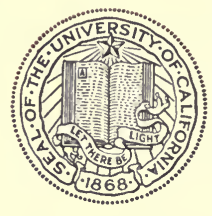

\section{LIBRARY}

THE UNIVERSITY OF CALIFORNIA

SANTA BARBARA FROM THE LIBRARY OF MRS. H. RUSSELL AMORY.

GIFT OF HER CHILDREN R. W. AND NINA PARTRIDGE. 


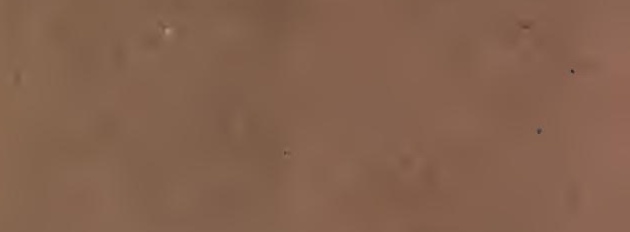

16

- 19 




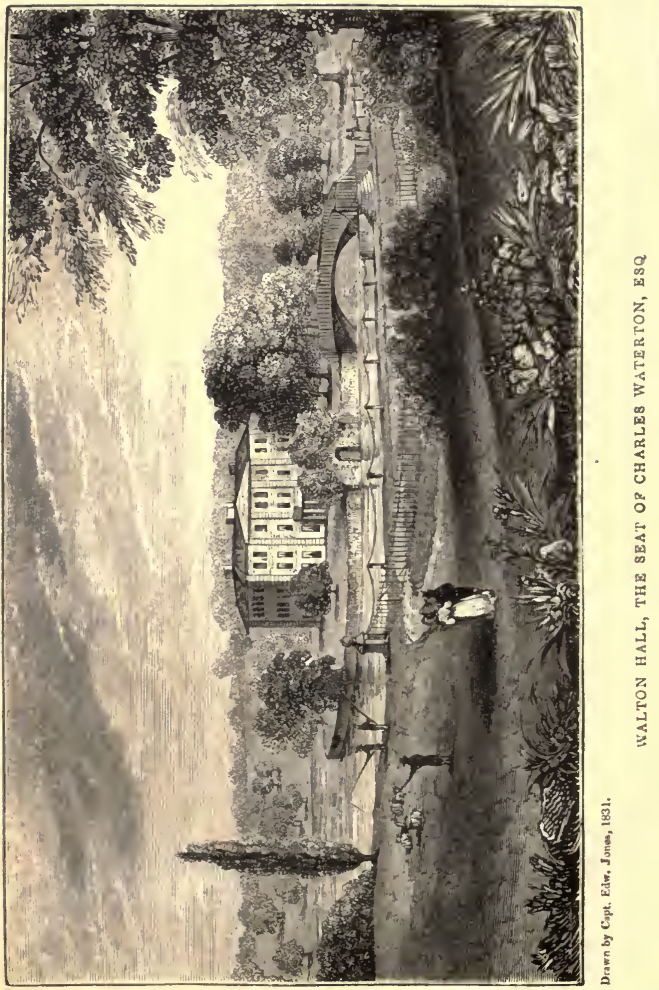




\section{ESSAYS}

ox

\section{N A T U R A L H I S TOR Y,}

CHIEFLY

ORNITHOLOGY.

$>$

BY

CHARLES WATERTON, ESQ. AUTHOR OF " WANDERINGS IN SOUTH AMERICA."

WITH AN AUTOBIOGRAPHY OF THE AUTHOR, AND A VIEW OF WALTON HALL.

\section{LONDON :}

LONGMAN, ORME, BROWN, GREEN, \& LONGMANS, PATERNOSTER-ROW.

1838. 
LoNDON :

Printed by A. Sportiswoove, New-Street-Square. 


\section{PR E F A C E.}

Some few years ago Mr. Loudon wrote to me, in order to draw my attention to his Magazine of Natural History; and he added in his letter, that he would feel obliged to me for any communication that I might send to him from time to time at my convenience.

I was preparing to set out for the Continent at the time that I received Mr. Loudon's letter. On my return home from Franconia, I did not forget his application relative to the Magazine of Natural History. I owe a debt of gratitude to Mr. Loudon, for the very kind manner in which he has always spoken of the Wanderings, and recommended that work to the public.

I had learned, by mere chance, that a professor in $\mathrm{Y}$ ing's College had been applying to 
the Wanderings for information concerning the Humming-Bird; and that, having got what he wanted, he had coupled my name with an epithet* any thing but congenial to my feelings. Upon this, with no other sensation than that which a man experiences when he receives a pinch which he knows that he does not deserve, I took up the new edition of the Ornithological Dictionary, and having given it a few hearty shakes, by way of retaliation, I laid it down again upon the table, and bade it rest in peace. This will account to the reader for the appearance of an extract from the Ornithological Dictionary in the first page of the following Essays.

Having had every possible opportunity of paying attention to the habits of the Vulture, during a long residence in the hotfest parts of South America, where this bird is found in vast abundance, I was convinced, and am still convinced beyond all doubt whatever, that the Vulture possesses the faculty of scent in a most superior degree; and I made mention in the 
Wanderings of this well-known faculty in the Vulture. A foreigner having imported into this country a theory quite at variance with what I had stated in my publication, I deemed it necessary, for the reputation of the Wanderings, to enter more minutely into the subject; wherefore I sent up to Mr. Loudon's Magazine of Natural History a paper on the habits of the Vulture. This gave rise to much contention, I trying to upset the new theory, and my adversaries striving to keep it on its legs. In the meantime, certain philosophers in the United States signed their names to a paper, which contained an account of experiments made upon the living Vulture, in order to prove its deficiency in the power of scent. One of these experiments was so horribly cruel, that the mere reading of it alone makes humanity shudder. These western sages promised that they would dissect the Vulture's nose; but I cannot learn that they have as yet commenced operations. They are fearful, no doubt, that they would discover in the beautifully developed parts of that bird's organ of scent, proof quite sufficient to show to them the inutility of their former experiments. 
Should it be remarked, that I have commented somewhat severely on certain parts of the Biography of Birds, I answer, that I should only have taken as much notice of that work as would have been necessary to prove that the new theory could not be depended upon, had not the partisans of the author given me ample cause of provocation. Had they continued under arms, it was my intention to have reviewed the whole of the Biography of Birds, together with the author's "Introductory Address."

The controversial papers which have appeared on different subjects in Mr. Loudon's Magazine are not included in these Essays. Had mine been introduced, those of my opponents must equally have been admitted, for the sake of perspicuity.

These Essays chiefly treat on the habits of birds. I cannot help observing, that too many of our histories of birds are both defective and erroneous. We can never expect to have a complete history of birds, until he, who undertakes the task of writing it, shall have studied his subject with unceasing attention in the field 
of Nature. When this shall have been done, then there will be no more mention made of owls erecting the feathery tufts on their heads in the moment of surprise; nor of young birds (no matter of what species) being able to fly at six days old. Numberless glaring faults will then be corrected, and the naturalist will experience real pleasure when he opens books which treat of ornithology.

I have carefully omitted the harsh names which have been given to our British birds : let those make use of them who attach importance , to them; I can make nothing of them.

Some of our birds, quadrupeds, and insects, have hitherto been described as particularly injurious to the interests of agriculture; others, as insatiate destroyers of fowls destined for our festive board; whilst others, again, are considered by the lower orders as agents, somehow or other, connected with witches, or with wisemen, as they are called in Yorkshire, who know of things lost, and of deeds done in the dark, and of places where pretty milkmaids may find deserving swains, ready and willing to become 
their lawful husbands, as soon as the bans shall have been duly published in the parish church. Thus they tell you, that rooks destroy young turnips; that carrion crows are always stealing eggs; and that hedgehogs suck the cows. The landlady " of a little inn in the village" knew that poor Lefèvre would not get better, for she had "heard the death-watch all night long." In fine, every body knows that there is to be an immediate wedding in the neighbourhood when he sees three magpies all together.

One of my objects in writing for Mr. Loudon's Magazine has been to try to do away the many accusations which ignorance and prejudice have brought forward to injure the character of our feathered'tribes; and I would fain hope to obtain mercy for my favourites at the hands of those who have hitherto ordered them to be destroyed. The task has by no means been difficult, for I possess the very best opportunities of observing the birds whose habits I have described.

I have only now to add, that Mr. Loudon, at 
his own expense, has ventured to collect and publish these Essays in their present form. I wish I had it in my power to present to his notice some production that would be more worthy of his indefatigable zeal in the cause of science. That he may receive ample patronage from a liberal public, and a remunerating compensation for the trouble which he has been put to, is the ardent wish of his sincere friend,

Charles Waterton.

Walton Hall, Dec. 2. 1837. 



\section{CONTENTS.}

Some Account of the Writer of the following Essays, by himself .

Page

xiii

Remarks on Professor Rennie's Edition of Montagu's

Ornithological Dictionary . . • .

The Habits of the Barn Owl, and the Benefits it confers

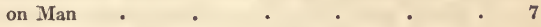

On the Faculty of Scent in the Vulture $\quad$. $\quad 17$

The Means by which the Turkey Buzzard traces its Food 29

The Vulture's Nose . $\quad$. $\quad$. $\quad$. $\quad 44$

Remarks on the Nudity on the Forehead and at the Base of the Bill of the Rook . . . . . 48

On the supposed Pouch under the Bill of the Rook . 54

On Birds using Oil from Glands " for the Purpose of lubricating the Surface of their Plumage " . . 60

On the Preservation of Egg-Shells for Cabinets of Na-

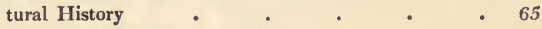

Mode of blowing Eggs $\quad$. $\quad$. $\quad$. 68

The Green Humming-Bird $\quad$ • $\quad$ • 69

The Vampire.$\quad$. $\quad . \quad$. $\quad$. 70

On preserving Insecțs selected for Cabinets $\quad$. 72

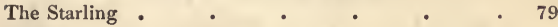

Preserving the Colour of the Legs and Bills of stuffed

Birds

The Habits of the Carrion Crow

Habits of the Pheasant

Habits of the Jackdaw

Defence against Animals of the Feline and Canine Tribes 112

Aerial Encounter of the Eagle and the Vulture . 122

The Humming-Bird . . . . . 125

The Virginian Partridge $\quad$. $\quad$. $\quad$. 128 
On the Habits of the Rook . . . 130 The Passenger Pigeon . . . 141

A description of the Habits of the Ringdove - . 145

Notes of a Visit to the Haunts of the Guillemot, and

Facts on its Habits

Notes of a Visit to the Haunts of the Cormorant, and

Facts on its Habits

Notes on the Habits of the Kingfisher

166

Notes on the Habits of the Tawny Owl a 172

Notes on the Habits of the Wigeon . . 178

Notes on the Habits of the Heron . . 183

The Dipper . . . . . 190

On the IIabits of the Water Ouzel, with a few Remarks on the Oil Glands in Birds . . . 193

Notes on the Habits of the Mallard . . 196

On Snakes, their Fangs, and their mode of procuring Food

Notes on the History and Habits of the Brown, or Grey, Rat

203

Remarks on Trees, with reference to their being perforated by the Titmouse and the Woodpecker 219

Notes on the Habits of the Jay - . . 226

Notes on the Habits of the Magpie . . . 232

Notes on the Habits of the Chegoe of Guiana, better known by the Name of Jigger; and Instances of its Effects on Man and Dogs . . . . 239

Notes on the Habits of the Dovecot Pigeon - 244

Notes on the Habits of the Stormcock, or Mistletoe Thrush

Notes on the Habits of the Windhover Hawk 257

The Rumpless Fowl . . . . . 262

The Raven . $\quad$. $\quad$. $\quad$. $\quad 267$

Apple Trees $\quad$ - . $\quad$. $\quad$. 275

The Chaffinch . . . . . $\quad 277$

A short Remark or two on what is commonly called

Dry Rot

Hints to Ornithologists

On Museums 


\section{SOME ACCOUNT}

or

THE WRITER OF THE FOLLOWING ESSAYS,

BY HIMSELF.

I THINK I have seen in a book, but I forget which just now, that, when we read a work, we generally have a wish to see the author's portrait, or, at least, to know something of him.

Under this impression, I conceive that a short account of myself will not be wholly uninteresting to the reader; who, it is to be hoped, will acquit me of egotism, as I declare, in all truth, that I write these Memoirs with no other object in view, than that of amusing him.

I was born at Walton Hall, near Wakefield, in the county of York, some five and fifty years ago: this tells me that I am no chicken; but, were I asked how I feel with regard to the approaches of old age, I should quote Dryden's translation of the description which the Roman poet has given us of Charon :

" He seem'd in years, yet in his years were seen A vernal vigour and autumnal green."

In fact, I feel as though I were not more than thirty years old. I am quite free from all rheumatic pains; and am so supple in the joints, that I can climb a tree with the utmost facility. I stand 
six feet high, all but half an inch. On looking at myself in the glass, I can see at once that my face is any thing but comely: continual exposure to the sun, and to the rains of the tropics, has furrowed it in places, and given it a tint, which neither Rowland's Kalydor, nor all the cosmetics on Belinda's toilette, would ever be able to remove. My hair, which I wear very short, was once of a shade betwixt brown and black: it has now the appearance as though it had passed the night exposed to a November hoarfrost. I cannot boast of any great strength of arm; but my legs, probably by much walking, and by frequently ascending trees, have acquired vast muscular power : so that, on taking a view of me from top to toe, you would say that the upper part of Tithonus has been placed upon the lower part of Ajax. Or, to speak zoologically, were I exhibited for show at a horse fair, some learned jockey would exclaim, he is half Rosinante, half Bucephalus.

I have preferred to give this short description of myself by the pen, rather than to have a drawing taken by the pencil, as I have a great repugnance to sit to an artist; although $I$ once did sit to the late Mr. Peale of Philadelphia, and he kept my portrait for his museum. Moreover, by giving this description of myself, it will prevent all chance, in future, of the nondescript's * portrait in the Wanderings being taken for my own.

- A late worthy baronet in the North Riding of Yorkshire, having taken up the Wanderings, and examined the representation of the nondescript with minute attention, "Dear ne!" said the, as he showed the engraving to his surrounding company, " what a very extraordinary lookin 
The poet tell us, that the good qualities of man and of cattle descend to their offspring. "Fortes creantur fortibus et bonis." If this holds good, I ought to be pretty well off, as far as breeding goes; for, on the father's side, I come in a direct line from Sir Thomas More, through my grandmother; whilst by the mother's side I am akin to the Bedingfelds of Oxburgh, to the Charltons of Hazleside, and to the Swinburnes of Capheaton.

My family has been at Walton Hall for some centuries. It emigrated into Yorkshire, from Waterton in the island of Axeholme in Lincolnshire, where it had been for a very long time. Indeed, I dare say I could trace it up to Father Adam, if my progenitors had only been as careful in preserving family records, as the Arabs are in recording the pedigree of their horses; for I do most firmly believe that we are all descended from Adam and his wife Eve, notwithstanding what certain selfsufficient philosophers may have advanced to the contrary. Old Matt Prior had probably an opportunity of laying his hands on family papers of the same purport as those which I have not been able to find; for he positively informs us that Adam and Eve were his ancestors :-

" Gentlemen, here, by your leave,

Lie the bones of Mathew Prior,

A son of Adam and of Eve:

Can Bourbon or Nassau go higher?"

Depend upon it, the man under Afric's burning zone, and he from the frozen regions of the north, have both come from the same stem. Their differ- 
ence in colour and in feature may be traced to this; viz., that the first has had too much, and the second too little, sun.

In remote times, some of my ancestors were sufficiently notorious to have had their names handed down to posterity. They fought at Cressy, and at Agincourt, and at Marston Moor. Sir Robert Waterton was Governor of Pontefract Castle, and had charge of King Richard II. Sir Hugh Waterton was executor to his Sovereign's will, and guardian to his daughters. Another ancestor was sent into France by the king, with orders to contract a royal marriage. He was allowed thirteen shillings a day for his trouble and travelling expenses. Another was Lord Chancellor of England, and preferred to lose his head rather than sacrifice his conscience. Another was master of the horse, and was deprived both of his commission and his estate, on the same account as the former. His descendants seemed determined to perpetuate their claim to the soil; for they sent a bailiff once in every seven years to dig up a sod on the territory. I was the first to discontinue this septennial act, seeing law and length of time against us.

Up to the reign of Henry VIII., things had gone on swimmingly for the Watertons; and it does not appear that any of them had ever been in disgrace. "Neque in his quisquam damnatus et exsul."

But, during the sway of that ferocious brute, there was a sad reverse of fortune :-

"Ex illo fluere, ac retro sublapsa referri, Spes Danaum." 
"From thence the tide of fortune left their shore, And ebb'd much faster than it flow'd before."

The cause of our disasters was briefly this:-The king fell scandalously in love with a buxom lass, and he wished to make her his lawful wife, notwithstanding that his most virtuous queen was still alive. Having applied to the head of the Church for a divorce, his request was not complied with; although Martin Luther, the apostate friar and creed-reformer, had allowed the Margrave of Hesse to have two wives at one and the same time. Upon this refusal, our royal goat became exceedingly mischievous: "Audax omnia perpeti ruit per vetitum nefas." Having caused himself to be made head of the church, he suppressed all the monasteries, and squandered their revenues amongst gamesters, harlots, mountebanks, and apostates. The poor, by his villanies, were reduced to great misery, and they took to evil ways in order to keep body and soul together. During this merciless reign, seventy-two thousand of them were hanged for thieving.

In good* Queen Mary's days there was a short tide of flood in our favour; and Thomas Waterton of Walton Hall was High Sheriff of York. This was the last public commission held by our family.

The succeeding reigns brought every species of reproach and indignity upon us. We were declared totally incapable of serving our country; we were held up to the scorn of a deluded multitude, as

- Camden, the Protestant historian, says that Queen Mary was a prin. cess never sufficiently to be commended of all men for pious and religious demeanewr, her commiseration towards the poor, \&c. 
damnable idolaters; and we were unceremoniously ousted out of our tenements : our only crime being a conscientious adherence to the creed of our ancestors, professed by England for nine long centuries before the Reformation. So determined were the new religionists that we should grope our way to heaven along the crooked and gloomy path which they had laid out for us, that they made us pay twenty pounds a month, by way of penalty, for refusing to hear a married parson read prayers in the church of Sandal Magna; which venerable edifice had been stripped of its altar, its crucifix, its chalice, its tabernacle, and all its holy ornaments, not for the love of God, but for the private use and benefit of those who had laid their sacrilegious hands upon them. My ancestors acted wisely. I myself (as I have already told the public in a printed letter,) would rather run the risk of going to hell with St. Edward the Confessor, Venerable Bede, and St. Thomas of Canterbury, than make a dash at heaven in company with Harry VIII., Queen Bess, and Dutch William.

Oliver Cromwell broke down our drawbridge; some of his musket balls remaining in one of the old oaken gates, which are in good repair to this day. Not being able to get in, he carried off every thing in the shape of horses and cattle that his men could lay their hands on.

Dutch William enacted doubly severe penal laws against us : during the reign of that sordid foreigner, some little relaxation was at last made in favour of dissenters; but it was particularly specified, that 
nothing contained in the act should be construed " to give ease to any papist or popish recusant."

My grandfather had the honour of being sent prisoner to York, a short time before the battle of Culloden, on account of his well-known attachment to the hereditary rights of kings, in the person of poor Charley Stuart, who was declared a pretender! On my grandfather's release, he found that his horses had been sent to Wakefield, there to be kept at his own expense. But the magistrates very graciously allowed him to purchase a horse for his own riding, provided the price of it was under five pounds.

My own father paid double taxes for some years after he came to the estate.

Times are better for us now: but I, individually, am not much better for the change; for I will never take Sir Robert Peel's oath. In framing that abominable oath, I don't believe that Sir Robert cared one fig's end whether the soul of a Catholic went up, after death, to the King of Brightness, or descended to the king of brimstone: his only aim seems to have been to secure to the church by law established, the full possession of the loaves and fishes. But, as I have a vehement inclination to make a grab at those loaves and fishes, in order to distribute a large proportion of them to the poor of Great Britain, who have an undoubted claim to it, I do not intend to have my hands tied behind me: hence my positive refusal to swallow Sir Robert Peel's * oath. Still, take it or refuse it,

* "I do hereby disclaim, disavow, and solemnly abjure any intention to subvert the present Church Establishment within this realm." \&c. (See Sir Robert Peel's Oath.) 
the new dynasty may always make sure of my loyalty, even if any of our old line of kings were still in existence; for

" The illustrious house of Hanover,

And Protestant succession,

To these $I$ have allegiance sworn,

While they can keep possession."

But to my life and adventures.

When I was not quite eight years old, I had managed to climb upon the roof of an out-house, and had got to a starling's nest under one of the slates. Had my foot slipped, I should have been in as bad a plight as was poor Ophelia in the willow tree, when the " envious sliver broke." The ancient housekeeper, mentioned in the account of the barnowl, had cast her rambling eye upon me. Seeing the danger I was in, she went and fetched a piece of gingerbread, with which she lured me down, and then she seized me, as though I had been a malefactor.

At nine years old, I was sent to a school in the north of England, where literature had scarcely any effect upon me, although it was duly administered in large doses by a very scientific hand. But I made vast proficiency in the art of finding birds' nests. It was judged necessary by the master of the school to repress this inordinate relish for ornithological architecture, which, in his estimation, could be productive of no good. Accordingly, the birch rod was brought to bear upon me when occasion offered; but the warm application of it, in 
lieu of effacing my ruling passion, did but tend to render it more distinct and clear. Thus are bright colours in crockery-ware made permanent by the action of fire; thus is dough turned into crust by submitting it to the oven's heat.

My first adventure on the water made a lasting impression, on account of the catastrophe which attended it. There was a large horsepond, separated by a hedge from the field which was allotted to the scholars for recreation-ground. An oblong tub, used for holding dough before it is baked, had just been placed by the side of the pond. I thought that I could like to have an excursion on the deep; so taking a couple of stakes out of the hedge, to serve as oars, I got into the tub, and pushed off ; “ Ripæ ulterioris amore."

I had got above half way over, when, behold, the master and the late Sir John Lawson of Brough Hall, suddenly rounded a corner and hove in sight. Terrified at their appearance, I first lost a stake, and then my balance: this caused the tub to roll like a man-of-war in a calm. Down I went to the bottom, and rose again covered with mud and dirt. "Terribili squalore Charon." My good old master looked grave, and I read my destiny in his countenance; but Sir John said that it was a brave adventure, and he saved me from being brought to a court-martial for disobedience of orders, and for having lost my vessel.

On my return home from this school, I was once within an ace of closing all accounts here below for a 3 
ever. About one o'clock in the morning, Monsieur Raquedel, the family chaplain, thought that he heard an unusual noise in the apartment next to his bed-room. He arose, and, on opening the door of the chamber whence the noise had proceeded, he saw me in the act of lifting up the sash; and he was just in time to save me from going out at a window three stories high. I was fast asleep; and, as soon as he caught hold of me, I gave a loud shriek. I thought I was on my way to a neighbouring wood, in which I knew of a crow's nest.

I was now shortly to be conducted to a place where at intervals I could attend to birds, without much risk of neglecting books.

The armies of the French republic having revolutionised some of the finest parts of Europe, and scourged the inhabitants; it was no longer safe for the Fathers of the Society of Jesus to remain in the town of Liège, where they had a celebrated college.

As the American war had caused a relaxation of the penal laws which had been put in execution against us with the most unrelenting severity, these good fathers ventured to revisit their native land, from which they had retired in early youth. The generous Mr. Weld of Lulworth Castle in Dorsetshire, immediately afforded them a resting place. He well knew their worth, and he gladly stepped forward to offer them his hand, in their utmost need. Having succeeded by inheritance to the stately mansion of Stonyhurst, near Clitheroe, in Lancashire, to it he directed their wandering steps, and bade them settle there. My father, who had been 
educated at the Jesuits' college in St. Omers, having learned that these inestimable disciples of St. Ignatius had put things in a proper train for the instruction of youth, took me to Stonyhurst, and placed me under their care.

Voltaire had said repeatedly that he could not subvert Christianity until he had destroyed the Jesuits. Their suppression was at last effected; partly by his own impious writings, and partly by the intrigues of kept mistresses at the different courts, who joined their influence to the already enormous power in the hands of the infidel ministers of the day. The woes unutterable which these poor followers of Jesus Christ had to endure at the hands of the wretches who had caused the breaking up of their order, seemed to have made no alteration in their disposition ; for, on my arrival at Stonyhurst, I found them mild and cheerful, and generous to all around them. During the whole of my stay with them (and I remained at their college till I was nearly twenty years old), I never heard one single expression come from their lips that was not suited to the ear of a gentleman and a Christian. Their watchfulness over the morals of their pupils was so intense, that I am ready to declare, were I on my death-bed, I never once had it in my power to open a book in which there was to be found a single paragraph of an immoral tendency.

My master was Father Clifford, a first cousin of the noble lord of that name. He had left the world, and all its alluring follies, that he might serve Almighty God more perfectly, and work his way with 
more security up to the regions of eternal bliss. After educating those entrusted to his charge with a care and affection truly paternal, he burst a bloodvessel, and retired to Palermo, for the benefit of a warmer climate. There he died the death of the just, in the habit of St. Ignatius.

One day, when I was in the class of poetry, and which was about two years before I left the college for good and all, he called me up to his room. " Charles," said he to me, in a tone of voice perfectly irresistible, "I have long been studying your disposition, and I clearly foresee that nothing will keep you at home. You will journey into far distant countries, where you will be exposed to many dangers. There is only one way for you to escape them. Promise me that, from this day forward, you will never put your lips to wine, or to spirituous liquors. The sacrifice is nothing," added he, "but, in the end, it will prove of incalculable advantage to you." I agreed to his enlightened proposal, and from that hour to this, which is now about nine and thirty years, I have never swallowed one glass of any kind of wine, or of ardent spirits.

At Stonylurst there are boundaries marked out to the students, which they are not allowed to pass; and there are prefects always pacing to and fro within the lines, to prevent any unlucky boy from straying on the other side of them. Notwithstanding the vigilance of these lynx-eyed guardians, I would now and then manage to escape, and would bolt into a very extensive labyrinth of yew and holly trees, close at hand. It was the chosen place for animated 
nature. Birds, in particular, used to frequent the spacious enclosure, both to obtain food and to enjoy security. Many a time have I hunted there, the foumart and the squirrel. I once took a cut through it to a neighbouring wood, where I knew of a carrion crow's nest. The prefect missed me; and, judging that I had gone into the labyrinth, he gave chase without loss of time. After eluding him in cover for nearly half an hour, being hard pressed, I took away down a hedgerow. Here (as I learned afterwards), he got a distant sight of me; but it was not sufficiently distinct for him to know to a certainty that I was the fugitive. I luckily succeeded in reaching the out-buildings which abutted on the college, and lay at a considerable distance from the place where I had first started. I had just time to enter the postern gate of a pigsty, where most opportunely I found old Joe Bowren, the brewer, bringing straw into the sty. He was more attached to me than to any other boy, for I had known him when I was at school in the north, and had made him a present of a very fine terrier. "I've just saved myself, Joe," said I; " cover me up with litter." He had barely complied with my request, when in bounced the prefect, by the same gate through which I had entered. "Have you seen Charles Waterton?" said he, quite out of breath. My trusty guardian answered, in a tone of voice which would have deceived any body, "Sir, I have not spoken a word to Charles Waterton these three days, to the best of my knowledge." Upon this, the prefect, having lost all scent of me, gave up the pursuit, and went his way. When he had dis- 
appeared, I stole out of cover, as strongly perfumed as was old Falstaff when they had turned him out of the buck-basket.

Once I had gone into the labyrinth to look into a magpie's nest, which was in a high holly tree; and, hearing the sound of voices near, I managed to get a resting place in the tree just over the nest, and there I squatted, waiting the event. Immediately, the President, two other Jesuits, and the present Mr. Salvin of Croxdale Hall, passed close under the tree, without perceiving me.

The good fathers were aware of my predominant propensity. Though it was innocent in itself, nevertheless it was productive of harm in its consequences; by causing me to break the college rules, and thus to give bad example to the community at large. Wherefore, with a magnanimity and excellent exercise of judgment, which are only the province of those who have acquired a consummate knowledge of human nature; and who know how to turn to advantage the extraordinary dispositions of those entrusted to their care, they sagaciously managed matters in such a way as to enable me to ride my hobby to a certain extent, and still, at the same time, to prevent me from giving bad example.

As the establishment was very large, and as it contained an abundance of prog; the Hanoverian rat, which fattens so well on English food, and which always contrives to thrust its nose into every man's house, where there is anything to be got, swarmed throughout the vast extent of this anti- 
quated mansion. The abilities which I showed in curtailing the career of this voracious intruder did not fail to bring me into considerable notice. The cook, the baker, the gardener, and my friend old Bowren, could all bear testimony to my progress in this line. By a mutual understanding, I was considered rat-catcher to the establishment, and also foxtaker, foumart-killer, and crossbow-charger, at the time when the young rooks were fledged. Moreover, I fulfilled the duties of organ-blower, and football-maker, with entire satisfaction to the public.

I was now at the height of my ambition.

— "Poteras jam, Cadme, videri

. . felix."

I followed up my calling with great success. The vermin disappeared by the dozen; the books were moderately well thumbed; and, according to $\mathrm{my}$ notion of things, all went on perfectly right.

When I had finished my rhetoric, it was my father's wish that I should return home. The day I left the Jesuits' college was one of heartfelt sorrow to me. Under Almighty God and my parents, I owe every thing to the fathers of the order of St. Ignatius. Their attention to my welfare was unceasing; whilst their solicitude for my advancement in virtue and in literature seemed to know no bounds. The permission which they granted me to work in my favourite vocation, when it did not interfere with the important duties of education, enabled me to commence a career, which, in after times, afforded me a world of pleasure in the far distant regions of Brazil and Guiana. To the latest 
hour of my life I shall acknowledge, with feelings of sincerest gratitude, the many acts of paternal kindness which I so often received at the hands of the learned and generous fathers of Stonyhurst College, "Præsidium et dulce decus meum."

After leaving this "safe retreat of health and peace," I journeyed homewards to join my father; and I spent a year with him, "Gaudens equis canibusque et aprici gramine campi." He was well described by the Roman poet:-

"Beatus ille, qui procul negotiis,

Ut prisca gens mortalium,

Paterna rura, bobus exercet suis

Solutus omni fænore."

He had been a noted hunter in his early days; and, as he still loved in lis heart to hear the mellow tones of the fox hound, he introduced me particularly to Lord Darlington, whose elegant seat on horseback, and cool intrepidity in charging fences, made him the admiration of his surrounding company.

Still my father would every now and then say to me, with a gracious though significant smile on his countenance, "Studium quid inutile tentas?" and, as my mother was very anxious that I should see the world, they took advantage of the short peace of Amiens, and sent me to Spain.

Two of my maternal uncles, who had received brilliant educations, and were endowed with great parts, but who were not considered worthy to serve their country in any genteel or confidential capacity, unless they would apostatize from the faith of their ancestors, had deemed it prudent to leave their 
native land, and retire to foreign climes. A Portuguese gentleman, named Martinez, who, in his travels through England, had received great hospitality from Sir Henry Bedingfeld of Oxburgh, in Norfolk, invited the wanderers to Malaga, where they finally settled, and became naturalised Spaniards.

I sailed from Hull in the month of November, with my younger brother (poor fellow! he died afterwards in Paumaron of the yellow fever), in the brig Industry, bound for Cadiz. The wind becoming adverse, we put into Margate Roads, and lay there for nine days. A breeze having sprung up from the northward, we went to sea again; in company with a Scotch brig, which was going to Vigo, and we were within gun-shot of each other the next morning at daybreak. On the preceding night, I had heard one of our own crew tell his comrade that, when he was ashore at Margate, a sailor from the Scotch brig had told him that their mate was in a conspiracy to murder the captain, and to run away with the vessel. I questioned our tar very particularly the following day, as the brig was not far off; and, finding his account quite consistent, $\mathbf{I}$ went down into the cabin, and committed it to paper. Having enclosed it in a bottle, we ran along side of the brig for Vigo, and hailed the captain. I then threw the bottle on the quarter-deck. The captain immediately took it up, and carried it below. He returned to the deck in a short time, and made us a very low bow ; which, no doubt, was the safest way to express his gratitude for the favour which we had done to him. We parted company in a gale of 
wind at night-fall, and I could never learn any thing afterwards of the brig, or of the fate of her commander.

On our arrival at Cadiz, we found the town illuminated; and there were bull fights in honour of royal nuptials. We accompanied Consul Duff to the amphitheatre. He was dressed in a brilliant scarlet uniform; and, though he had cautioned us not to lose sight of him as soon as the entertainment should be finished, still my eyes wandered upon a thousand objects, and I most unfortunately missed him, just as we were departing from the amphitheatre. As there were hundreds of Spaniards in scarlet cloaks, it was probably on this account that the consul had been particular in requesting us to keep him always in view. I walked up and down Cadiz till nearly midnight, without being able to speak one word of Spanish, and trying in vain to find the British consul's house. At last, in utter despair, I resolved to stand still, and to endeavour to make out some passing Frenchman, or some American, by the light of the moon, which shone brilliantly upon the white houses on each side of the street. The first person whom I accosted luckily turned out to be a French gentleman. I told him that I was a stranger, and that I was benighted, and had lost my way. He most kindly took me to the consul's house, which was a long way off.

After staying a fortnight in Cadiz, we sailed through the Straits of Gibraltar, for Malaga in Andalusia; a province famous for its wine, its pomegranates, its oranges, and its melons. 
My uncles had a pleasant country-house at the foot of the adjacent mountains, and many were the days of rural amusement which I passed at it. The redlegged partridges abounded in the environs, and the vultures were remarkably large; whilst goldfinches appeared to be much more common than sparrows in this country. During the spring, the quails and bee-eaters arrived in vast numbers, from the opposite coast of Africa. Once when I was rambling on the sea shore, a flock of a dozen red flamingoes passed nearly within gun-shot of me.

At my uncles' house, I made the acquaintance of an English gentleman who had been staying with them for some time. He was travelling in Spain to obtain commercial orders, in favour of his Firm in England; which was most respectable. He was a pleasant, laughing, well-made, dapper, little man; and, as he was full of information, which he had collected in the different places through which he had passed, I found his conversation very agreeable; and we made arrangements to go to Cadiz by land, taking Gibraltar in our way.

It is a well-known fact, that apes are found in no part of Europe except in Gibraltar. They inhabit the steepest parts of the mountain, and always prefer to be sheltered from the wind, when it blows hard. I had letters of introduction to the Danish consul, Mr. Glynn. As good luck would have it, the wind changed to the eastward on the very morning on which the consul had arranged to show us over the rock of Gibraltar. He said that the apes were sure to be on the move, as the change 
of wind would force them from their quarters; and actually, on our way up the mountain, we had a fair view of the apes on their passage. I counted from fifty to sixty of them; and an ape or two might be seen in the flock, with a young one on its back. Æneas in his day reversed the thing, and carried an old animal; not a young one.

"Cessi, et sublato montem genitore petivi."

We visited Algesiras, and there I saw the Hannibal seventy-four aground. Colonel Lyon of St. Roque gave us a full account of her misfortune. This brave old Irish gentleman, aware that there would be no promotion for him in his own country, on account of his adherence to the ancient creed, had left it with many others in early life, and entered the Spanish brigade.

\section{"Interque mœrentes amicos, Egregius, properârat exul."}

He told us he was standing in the fort of St. Roque just at the time that the Hannibal ran aground, and was forced to strike her colours to the guns of Algesiras. At that moment, unconquerable love of his deserted country took possession of his soul. He threw down a telescope which he held in his hand, and burst into a flood of tears. After he had told us this, he added that, whilst Sir James Saumarez was hotly engaged with the forts, his son, a boy of only eleven years old, stole away from St. Roque, and ran round the bay to Algesiras. There he mounted the battery, against which Sir James was 
directing his heaviest shot; and he helped to serve the guns till all was over.

"On the boy's safe return lome," said the colonel, "though I admired his bravery, I was obliged to whip him for his rashness in having exposed himself to almost inevitable death."

I thought I could perceive a mark in the colonel's face, as he said this, which led me to understand that there was something more than paternal anxiety for the boy's welfare which had caused him to apply the rod; and, when I called to mind the affair of the telescope, I concluded that, had a French squadron, in lieu of an English one, been bombarding Algesiras, young Lyon would have escaped even without a reprimand.

I left my travelling friend in Cadiz, and returned to Malaga on board a Spaniard, who kept close under Ceuta, as we passed up the Straits of Gibraltar. It grieves me to add that, many years after this, on my return to England from the West Indies, in passing through my former companion's native town, I made inquiries after him, and I was informed by a gentleman who had sat upon the inquest, that my companion had fallen in love, had wooed in vain, and hanged himself in despair.

More than a year of my life had now passed away in Malaga and its vicinity, without misfortune, without care, and without annoyance of any kind. The climate was delicious; and I felt regret in making preparations to leave this old Moorish town on a trip to Malta. But the Spanish proverb infor msus, that man proposes, and God disposes : 
“El hombre pone, y Dios dispone." Many a bright and glorious morning ends in a gloomy setting sun.

There began to be reports spread up and down the city that the black vomit had made its appearance; and every succeeding day brought testimony that things were not as they ought to be. I myself, in an alley near my uncle's house, saw a mattress of most suspicious appearance hung out to dry. A Maltese captain, who had dined with us in good health at one o'clock, lay dead in his cabin before sunrise the next morning. A few days after this, I was seized with vomiting and fever during the night. I lad the most dreadful spasms, and it was supposed that I could not last out till noon the next day. However, strength of constitution got me through it. In three weeks more, multitudes were seen to leave the city, which shortly after was declared to be in a state of pestilence. Some affirmed that the disorder had come from the Levant; others said that it had been imported from the Havanna; but $I$ think it probable that nobody could tell in what quarter it had originated.

We had now all retired to the country house; my eldest uncle returning to Malaga from time to time, according as the pressure of business demanded his presence in the city. He left us one Sunday evening, and said he would be back again some time on Monday; but that was my poor uncle's last day's ride. On arriving at his house in Malaga, there was a messenger waiting to inform him that Father Bustamante had fallen sick, and wished to 
see him. Father Bustamante was an aged priest, who had been particularly kind to my uncle on his first arrival in Malaga. My uncle went immediately to Father Bustamante, gave him every consolation in his power, and then returned to his own house, very unwell, there to die a martyr to his charity. Father Bustamante breathed his last before daylight; my uncle took to his bed, and never rose more. As soon as we had received information of his sickness, I immediately set out on foot for the city. His friend Mr. Power, now of Gibraltar, was already in his room, doing every thing that friendship could suggest, or prudence dictate. My uncle's athletic constitution bore up against the disease much longer than we thought it possible. $\mathrm{He}$ struggled with it for five days, and sank at last about the hour of sunset. He stood six feet four inches high ; and was of so kind and generous a disposition, that he was beloved by all who knew him. Many: a Spanish tear flowed when it was known that he had ceased to be. We got him a kind of coffin made, in which he was conveyed at midnight to the outskirts of the town, there to be put into one of the pits which the galley-slaves had dug, during the day, for the reception of the dead. But they could not spare room for the coffin; so the body was taken out of it, and thrown upon the heap which already occupied the pit. A Spanish marquis lay just below him.

"Divesne prisco natus ab Inacho,

Nil interest, an pauper, et infimâ

De gente."

Thousands died as though they had been seized b 2 
with cholera; others with black vomit, and others of decided yellow fever. There were a few instances of some who departed this life with very little pain, or bad symptoms. They felt unwell; they went to bed; they had an idea that they would not get better, and they expired in a kind of slumber. It was sad in the extreme to see the bodies placed in the streets at the close of day, to be ready for the dead-carts as they passed along.

" Plurima perque vias, sternuntur inertia passim Corpora."

The dogs howled fearfully during the night. All was gloom and horror in every street; and you might see the vultures on the strand, tugging at the bodies which were washed ashore by the eastern wind. It was always said that 50,000 people left the city at the commencement of the pestilence; and that 14,000 of those who remained in it fell victims to the disease.

There was an intrigue going on at court, $f$ or the interest of certain powerful people, to keep the port of Malaga closed, long after the city had been declared free from the disorder; so that none of the vessels in the mole could obtain permission to depart for their destination.

In the mean time, the city was shaken with earthquakes; shock succeeding shock, till we all imagined that a catastrophe awaited us similar to that which had taken place at Lisbon. The pestilence killed you by degrees; and its approaches were sufficiently slow, in general, to enable you to submit to it with firmness and resignation. But the idea of being 
swallowed up alive by the yawning earth, at a moment's notice, made you sick at heart, and rendered you almost fearful of your own shadow.

The first shock took place at six in the evening, with a noise as though a thousand carriages had dashed against each other. This terrified many people to such a degree, that they paced all niglit long up and down the Alameda, or public walk, rather than retire to their homes. I went to bed a little after midnight; but was roused by another shock, about five o'clock in the morning. It gave the bed a motion, which made me fancy that it moved under me from side to side. I sprang up, and, having put on my unmentionables (we wore no trousers in those days), I ran out, in all haste, to the Alameda. There the scene was most distressing: multitudes of both sexes, some nearly in a state of nudity, and others sick at stomach, were huddled together, not knowing which way to turn, or what to do.

\section{"Omnes eodem cogimur."}

However, it pleased Heaven, in its mercy, to spare us. The succeeding shocks became weaker and weaker, till at last we felt no more of them.

I now began to think it high time to fly. I was acquainted with a Swedish captain, by name Bolin; a most excellent man, and of surprising intrepidity and coolness. His brig having been long laden with fruit for London, he was anxious to depart; and he formed a plan to escape from the harbour. There was no getting a regular clearance at the custom-house; 
neither would the Swedish consul afford any assistance; so I went to our own consul, Mr. Laird, with whom I was very intimate, requesting him to give me a certificate to signify that there had not been any sickness in the city for a long time : indeed, it was now in a remarkably healthy state. The consul complied with my request : as he put the certificate into my hand, "My young friend," said he, in a very feeling tone, "I shall either have to see you sunk by the cannon of the fort, or hear of your being sent prisoner for life to the fortress of Ceuta, on the coast of Africa."

I now endeavoured to persuade my remaining uncle to try his fortune with me; but my cntreaties were of no avail. He fell an early victim to the fever, which returned with increased virulence the following spring. A letter which I received from my worthy friend, Mr. Dillon of Alhaurin, some twenty miles from Malaga, informed me that it swept away 36,000 souls.

Our captain had taken the precaution to make out false papers, in case of need, on account of the war betwixt Great Britain and France. My brother was entered as a passenger, myself as a Swedish carpenter. We slept on board for many successive nights, in hopes of a fair wind to carry us through the Straits. At last a real east wind did come, and it blew with great violence. The captain, whose foresight and precautions were truly admirable, had given the strictest orders to the crew that not a word should be spoken whilst we were preparing to escape. We lay in close tier amongst forty sail of 
merchantmen. The harbour-master, having come his usual rounds, and found all right, passed on without making any observations. At one o'clock, post meridiem, just as the governor had gone to the eastward to take an airing in his carriage, as was his custom every day; and the boats of two Spanish brigs of war at anchor in the harbour had landed their officers for the afternoon's amusements, our vessel worked out clear of the rest, and instantly became a cloud of canvass. The captain's countenance, which was very manly, exhibited a portrait of cool intrepidity rarely seen : had I possessed the power, I would have made him an admiral on the spot. The vessel drove through the surge with such a press of sail, that I expected every moment to see her topmasts carried away. Long before the brigs of war had got their officers on board, and had weighed in chase of us, we were far at sea; and when night had set in, we lost sight of them for ever; our vessel passing Gibraltar at the rate of nearly eleven knots an hour.

The wind headed us the following night. After thirty days of cold and stormy weather, we ran the risk of following a fishing boat, for want of a pilot, and anchored off Brownsea Castle, near Poole in Dorsetshire; an adverse wind not permitting us to proceed up Channel. Here we sent our papers, and Consul Laird's certificate up to London. Contrary to my expectations, we received permission in due time to proceed up the Thames. I had often told Captain Bolin, during the voyage, that we should be sent back to the Mediterranean for a regular 
bill of health; but he thought otherwise, and he was right.

I brouglit over with me from Spain a superbly mounted Spanish gun, and a beautiful ivory crucifix : they had been a present from the Duchess of Alva to my deceased uncle. The gun is the identical one which the famous Duke of Alva had with him in the Low Countries: my uncle always intended it for his relative, the late Sir Richard Bedingfeld, Bart., of Oxburgh in Norfolk, to whiclı place I sent it. The crucifix had been taken away from Rome, by a French general, in 1796 : it was a present to my mother, and is now at Walton Hall.

Up to the time of my leaving England for the Mediterranean, I had been accustomed to drink a little beer at dinner; but, finding the taste of it bitter on my return, I put the glass down upon the table without swallowing its contents, and have never since drunk one drop of fermented liquors.

The pestilence at Malaga had shaken me con. siderably. Being but thinly clad, in coming up the Channel I caught a cold, which attacked the lungs, and reduced me to the brink of the grave. I must have sunk, had it not been for the skill of the late celebrated surgeon, Mr. Hey of Leeds : he set me on my legs again; and I again hunted with Lord Darlington. But the bleak and wintry wind of England ill suited a frame naturally chilly, and injured by what had already happened. I longed to bask in a warmer sun.

My paternal uncle having estates in Demerara, and my father having lately made a purchase there, 
for the benefit of his younger children, I petitioned to be allowed to go out and superintend them; seeing that there was no chance of travelling with comfort in Europe on account of the war, which had all the appearance of becoming general.

Our family found its way to the New World in the following manner:- My father's sister was remarkably handsome. As she was one day walking in the streets of Wakefield, a gentleman, by name Daly, from Demerara, met her accidentally, and fell desperately in love with her: they were married in due course of time, although the family was very much averse to the match. Soon after this, my father's younger brother, who had no hopes at home on account of the penal laws, followed his sister to Demerara, and settled there.

All having been arranged for my departure, I proceeded to London, where my maternal uncle, the late intrepid Sir John Bedingfeld, who had saved the king's life in the year 1796, introduced me to Sir Joseph Banks, who ever after took a warm interest in my adventures. He particularly impressed upon my mind his conviction that all low and swampy countries within the tropics are in general very insalubrious, and fatal to European constitutions. "You may stay in them," said he to me, "for three years or so, and not suffer much. After that period, fever and ague, and probably a liver disease, will attack you, and you will die at last, worn out, unless you remove in time to a more favoured climate. Wherefore," continued he, "as you have not your bread to seek, you must come 
home once in three years, at farthest, and then all will go right." I followed this admirable advice with great success : still, I used to think that I ran less risk of perishing in those unwholesome swamps than most other Europeans, as I never found the weather too hot, and I could go bareheaded under a nearly equatorial sun, without experiencing any inconvenience. Too often, however, might others have exclaimed with Admiral Hosier's ghost :-

"Sent in this foul clime to languish,

Think what thousands fall in vain;

Wasted with disease and anguish,

Not in glorious battle slain."

I sailed from Portsmouth in the ship Fame, Captain Brand, on November 29. 1804, and landed at the town of Stabroek, in ci.devant Dutch Guiana, after a passage of about six weeks. I liked the country uncommonly, and administered to the estates till 1812 ; coming home at intervals, agreeably to the excellent and necessary advice which I had received from Sir Joseph Banks. In the month of April, 1812, my father and uncle being dead, I delivered over the estates to those concerned in them, and never more put foot upon them.

In my subsequent visits to Guiana, having no other object in view than that of natural history, I merely staid a day or two in the town of Stabroek (now called George Town), to procure what necessaries I wanted; and then I hastened up into the forests of the interior, as the Wanderings will show.

Whilst I was on the estates, I had the finest 
opportunity in the world of examining the waterfowl of Guiana : they were in vast abundance. all along the sea shore, and in the fresh-water swamps behind the plantations. No country in the world can offer a more extensive and fertile field to the ornithologist, than our celebrated colony of Demerara. . - I had several adventures during the time that the estates were under my charge. Perhaps it will be well to recount them here: they will tend to enliven a little this dull attempt on my part at autobiography ; or, more properly speaking, an attempt to amuse the reader of these Essays at my own cost, should my memoirs fall into the hands of a surly critic. However, be this as it may, let me here inform the reader that there shall not be a single exaggeration in any part of them.

During the war betwixt Spain and England, the privateers from the Orinoco were perpetually scouring the coast of Essequibo, and committing ruinous devastations on the property of the British planters. One morning, five or six English gentlemen, amongst wliom was my friend Mr. Robert. Gordon, afterwards Governor of Berbice, went out in a schooner, with Mr. Hubbard, an Ameriean, to attack a privateer which had appeared in the offing. A person by the name of Lynch (I knew him well) was one of the party. He had a foreboding that all would not go right ; for, just as he was entering the vessel which was to take him out to battle, he gave his, watch to a friend, and he begged it might be sent to his father in Ireland, should he. not return. He was a light little man, apparently 
not cut out for rough or hazardous undertakings. Our adventurers had better staid at home. The Spaniard bore down upon their schooner, and immediately took possession of her.

As these gentlemen had gone out to battle on the high seas without a commission from government, their friends in Demerara had serious apprehensions, and not without reason, that they ran a risk of being tucked up for pirates on their reaching the Spanish settlements in the Orinoco.

Being the only person in Demerara acquainted with the Spanish language, I volunteered my services to go in quest of the unfortunates. Their friends accepted the offer with abundant thanks; and, having engaged a vessel for me, I sailed with a Mr. Charles Gordon (a relative of one of the prisoners), for Barbadoes, to receive letters and instructions from Admiral Sir Alexander Cochrane. My instructions from Colonel Nicholson, the Governor of Demerara, bear date October 24. 1807.

A little before this (that is, on the 11 th of September in the same year), I had received from Colonel Nicholson my commission of lieutenant in the $2 \mathrm{~d}$ regiment of militia. As no declaration had been previously required from me against transubstantiation, nor any promise that I would support the nine and thirty articles of faith by law established, nor any inuendoes thrown out touching the "devil, the Pope, and the Pretender," I was free in conscience to accept of this commission. It was the first commission that any one of the name of Waterton had received from Queen Mary's days. 
During that long interval, not a Waterton could be found vicious enough to regain his lost birthright at the incalculable sacrifice of conscience. It had been the object of those in power to tempt us to deviate into their new road, which they said would lead to heaven, but we were quite satisfied with the old beaten path; so that the threats, and the allurements, and the cruel enactments of our would-be seducers were of no avail; saving that we were brought down from our once high estate, and rendered very small (and are yet very small) in the eyes of our fellow-subjects. But every dog has his day: To-day for thee, to-morrow for me, as Sancho Panza says. And now to Barbadoes.

During our passage, I observed that the sailors were far too often at the pump, which forced up clear sea-water from the vessel's hold; so, without making any remarks on what I had witnessed, I took care to put Daniel's life-preserver under my pillow, in case of need: I had bought it at Portsmouth, on the recommendation of a Captain Baker. The schooner went down at anchor, on the night of the day that we reached Barbadoes.

The Admiral had unfortunately sailed for the Saintes ; but, as he was expected to return immediately, it was judged best to await his arrival in Carlisle Bay.

Some time before this, Captain Rogers, of the Windsor Castle packet, had had lis celebrated engagement with the Jeune Adèle French privateer, from Martinique. Her captain had fallen in the contest ; and her lieutenant, Monsieur Flagelle, was 
a prisoner of war in Bridgetown. I was introduced to him; and, finding him an officer of most amiable manners and superior education, I helped him a little in money matters, and did him other trivial acts of kindness. He told me that he had been brought up for the marine marchande; and that he never thought he should be reduced to the necessity of going on board a privateer; but the English cruisers having nearly put an end to French commerce by sea, there was no other way left open for him to get on in the world. He was sorry he could make me no return, as he was a prisoner in a foreign land; but he would write a letter for me, which possibly might be of service to me on some future day. Next morning, Lieutenant Flagelle presented me with a letter, in which he requested that all captains of French men-of-war and of privateers in the Caribbean Sea would treat me with kindness and attention, should misfortune throw me into their power.

It was at Barbadoes that I made the acquaintance of Captain Beaver, who commanded the Acasta frigate of 44 guns. I was told, some years ago, that this scientific officer died an admiral, whilst at anchor at the Cape of Good Hope. Mr. Maxwell, the navy agent in Barbadoes, had given a large dinner party at his country house near Bridgetown. I sat next Captain Beaver at dinner. During the dessert, he amused the company with a facetious story of an interview which formerly had taken place betwixt Lord Melville and John Bedingfeld 
of the Navy Pay-Office. When he had finished his story, I told him that Mr. Bedingfeld was my uncle.

I was breakfasting one morning on board the Acasta, when I perceived that Captain Beaver seemed to be very particular in having his crest on different articles of furniture in the cabin : his crest was a beaver, and mine is an otter. My uncle Bedingfeld had invented a dagger of curious construction, adapted to the boarding of vessels. I had got one made in London, under his directions. It was silver-mounted, and had my crest upon it; so I begged Captain Beaver to accept it as a keepsake from me. I mention this little anecdote merely in order that his relatives may know whence the dagger came, should it be now in their possession.

Whilst I was waiting in Bridgetown for Admiral Cochrane's return from the Saintes, a letter arrived to inform me that there was no necessity for my proceeding to the Orinoco, as all the English gentlemen were safe. They had risen on the Spanish crew, at the mouth of the Orinoco, and had retaken their vessel. During the scuffle, poor little Lynch got jostled overboard and was drowned, being the only white man who lost his life in the fray. After the retaking of the vessel, our Englishmen steered for Tobago, whither they arrived just in time to save their lives, for they were nearly in a dying state for want of water.

I left Barbadoes with regret. It was head-quarters, during the war, for the navy and the army. Our troops and tars kept it in one perpetual round of gaiety. 
"Nunc est bibendum, nunc pede libero Pulsanća tellus,"

was all the go in Bridgetown.

Notwithstanding the most guarded sobriety and abstinence on my part, the fever and ague would at times assault me with great obstinacy. The attacks could always be traced to my getting wet, and remaining in my wet clothes until the sun had dried them; a custom never to be sufficiently condemned in any country. But, as Fénélon remarks, "La jeunesse est présomptueuse: elle se promet tout d'elle-même; quoique fragile, elle croit pouvoir tout, et n'avoir jamais rien à craindre: elle se confie légèrement, et sans précaution."

When the ague came on to any serious extent, I would go up to Mr. Edmonstone's house, in Mibiri Creek, for change of air. He was the most valued friend I ever had in the world; and I seldom failed to recover my health during the time that I remained with him. His nephew, Mr. Archibald Edmonstone, was all hospitality and kindness. He was very knowing in the woods, and would find out the fruit-bearing trees, where the finest birds in Guiana were to be seen. Nobody was better acquainted with the forest trees than he was. I have by me a catalogue of his, in which he enumerates nearly seventy trees found in that neighbourhood; and he gives the size at which they generally arrive, their Indian names, their qualities, and their uses.

In the year 1808, Admiral Collingwood having sent despatches to Demerara for the Spanish government in the Orinoco, I was requested by Governor Ross to be the bearer of them. 
As my friend Mr. Edmonstone was but in a poor state of health, I thought a change of air would be of service to him. At my earnest entreaty, his name was included in the commission. The governor, at first, intimated a wish for him to go as a private friend; but, on my remarking that the Spanish forts in the lower part of the Oronoquo might refuse assent to his proceeding to Angustura, the capital, unless his name appeared in the commission, there was no farther objection on the part of the governor, and his name was put in the commission.

I rashly procured the same favour for a person who had better have staid at home. He never let me rest one moment until I had got the governor to allow him to accompany us. He was in years, and could not speak one word of Spanish. I only saw my error when it was too late. He ill-requited the favour which I had procured for him.

I now waited on the governor for the last time; and, after he had imparted to me lis private instructions on certain points which he wished me to ascertain during my stay in Angustura, he gave me my commission, together with the dispatches of Admiral Collingwood, for the captain general of the Oronoquo. The commission is dated Aug. 2. 1808.

I sailed from Demerara in the Levina flag of truce. After we had doubled Point Barima, we found the current rushing down with astonishing rapidity, and carrying with it enormous fragments of trees into the Atlantic Ocean. We soon found it necessary to get the vessel into the eddy water, close to the bank; 
and at all the points where the stream met us, we carried out a hawser in the small boat, and lashed it to the branches of the trees which overhung the river. By means of this perpetual warping, we worked our slow and tedious way up to Sacopan, and thence to the fort at Barrancas, where the Spanish officers provided us with a craft of their own. It was a long boat, schooner rigged, and admirably adapted to the service for which it was intended. During the whole of the passage up the river, there was a grand feast for the eyes and ears of an ornithologist. In the swampy parts of the wooded islands, which abound in this mighty river, we saw water fowl innumerable; and when we had reached the higher grounds, it was quite charming to observe the immense quantities of parrots and scarlet aras which passed over our heads. The loud, harsh screams of the bird called the horned-screamer, were heard far and near ; and I could frequently get a sight of this extraordinary bird, as we passed along; but I never managed to bring one down with the gun, on account of the difficulty of approaching it. John Edmonstone, who is now in Edinburgh, will remember well this expedition.

Whilst we were wending our way up the river, an accident happened of a somewhat singular nature. There was a large labarri snake coiled up in a bush, which was close to us. I fired at it, and wounded it so severely that it could not escape. Being wishful to dissect it, I reached over into the bush, with the intention to seize it by the throat, and convey it aboard. The Spaniard at the tiller, on seeing this, 
took the alarm, and immediately put his helm aport. This forced the vessel's head to the stream, and I was left hanging to the bush with the snake close to me, not having been able to recover my balance as the vessel vecred from the land. I kept firm hold of the branch to which I was clinging, and was three times over-head in the water below, presenting an easy prey to any alligator that might have been on the look-out for a meal. Luckily, a man who was standing near the pilot, on seeing what had happened, rushed to the helm, seized hold of it, and put it hard a-starboard, in time to bring the head of the vessel back again. As they were pulling me up, I saw that the snake was evidently too far gone to do mischief; and so I laid hold of it, and brought it aboard with me, to the horror and surprise of the crew. It measured eight feet in length. As soon as I had got a change of clothes, I killed it, and made a dissection of the head.

1 would sometimes go ashore in the swamps to shoot maroudies, which are somewhat related to the pheasant; but they were very shy, and it required considerable address to get within shot of them. In these little excursions, I now and then smarted for my pains. More than once, I got amongst some hungry leeches, which made pretty free with my legs. The morning after I had had the adventure with the labarri snake, a cayman slowly passed our vessel. All on board agreed that this tyrant of the fresh waters, could not be less than thirty feet long.

On arriving at Angustura, the capital of the Oronoquo, we were received with great politeness by the 
governor. Nothing could surpass the hospitality of the principal inhabitants. They never seemed satisfied unless we were partaking of the dainties which their houses afforded. Indeed, we had feasting, dancing, and music, in superabundance. The governor, Don Felipe de Ynciarte, was tall and corpulent. On our first introduction, he told me, that he expected the pleasure of our company to dinner every day during our stay in Angustura. We had certainly every reason to entertain very high notions of the plentiful supply of good things which the Oronoquo afforded; for, at the first aay's dinner, we counted no less than forty dishes of fish and flesh.

The governor was superbly attired in full unifurm of gold and blue; the weight of which alone, in that hot climate, and at such a repast, was enough to have melted him down. He had not got half through his soup, before he began visibly to liquefy. I looked at him, and bethought me of the old saying, "How I sweat ! said the mutton chop to the gridiron." He now became exceedingly uneasy; and I myself had cause for alarm; but our sensations arose from very different causes. He, no doubt, already felt that the tightness of his uniform, and the weight of the ornaments upon it, would never allow him to get through that day's dinner with any d'gree of comfort to himself. I, on the other hand (who would have been amply satisfied with one dish well done), was horrified at the appalling sight of so many meats before me. Good breeding whispered to me, and said, "Try a little of nost of them." Temperance replied, "Do so at your peril : and, for your over-strained courtesy, 
you shall have yellow fever before midnight." At last, the governor said to me in Spanish, "Don Carlos, this is more than man can bear. No puedo sufrir tanto. Pray pull off your coat, and tell your companions to do the same; and I'll show them the example." On saying this, he stripped to the waistcoat; and I and my friends, and every officer at table, did the same. The next day, at dinner-time, we found his Excellency clad in a uniform of blue Salempore, slightly edged with gold lace.

Don Felipe de Ynciarte had been a great explorer of Spanish Guiana in his day. He told me that he, in person, dressed as a common sailor, had surveyed the whole of the sea coast from the Oronoquo to the river Essequibo. He let me look at a superb map of his own drawing. It was beautifully finished, and my lips certainly watered to have a copy taken of it. After my return to Demerara, I sent this courteous governor a fine telescope, which had just arrived from London. I corresponded with him until I sailed to Europe for my health. During his government, beef was so plentiful, that the heads and tongues of the slaughtered oxen were thrown to the vultures. Indeed, beef was only one penny a pound, and the finest fish could be had almost for nothing.

Canning's new republics, which have arisen out of the former Spanish transatlantic empire, may have tended to enrich a few needy adventurers from Europe; but, to the natives in general, they have proved a mighty curse.

Demerara was now shortly to be deprived of the valuable services of Governor Ross. His health had 
already begun to give way; and, after he had battled with his disease for some time, he was obliged to consign his government over to other hands, and to try a voyage to Europe. He got well in his native country. But, alas, we are here to-day, and gone to-morrow. This brave officer, and truly just man, was ordered to Alicante in Spain, where he fell a victim to the prevailing fever.

Governor Ross was beloved to enthusiasm by the inhabitants of Demerara. On the 31st of March, 1809, we sent an address to him, expressive of our warmest gratitude for the many services he liad rendered to us during the time that the colony was under his charge; and we made a subscription of 1500 guineas, which token of public gratitude was presented to him with due form.

I wrote the following tribute, and it appeared in the newspaper the day after the governor had sailed from the river Demerara, on his way to Europe for the recovery of his health.

\section{CARMEN SAPPHICUM.}

Tristis heu nobis, nimiumque durus

Ordo Parcarum est! Demerara damnum

Flet repentinum, lacrymasque fundet,

Tempus in omne.

Ille, qui justis manibus regebat

Lora, jam currum, medio reliquit

Cursu, et invitis pedibus remola

Gramina quærit.

Tempore æstivo, rutilans ut agri

Ros fovet gramen sitientis - Ille,

Sic opem nobis, tulit, et levamen,

Auxiliumque. 
Hâc die pectus, rigidum dolorem

Sentit, et luctum lacrymæ sequuntur,

Dum Ducem nostrum, Demeraræ ab oris

Cedere cerno.

Te, procellosos pelagi tridenti

Qui regis fluctus, precor o secundo

Numine adsis, dum liquido carina

Equore fertur.

General Carmichael was governor of Demerara in 1812, the year in which I took a final leave of the Estates, and went far into the interior of Guiana, in quest of the wourali poison. (See The Wanderings.)

The general had one of the most difficult tempers in the world to manage. His disposition was generous, but at the same time it was exceedingly fiery ; although his ire soon subsided, unless it had received extraordinary and repeated provocation. He had such a profound veneration for royalty, that I do believe he would have sent his own brother out of the house, had he heard him speak with levity of the Prince Regent of England.

In person he was shrivelled and weatherbeaten, and of diminutive stature; but he was wonderfully active, and vigorous in mind, notwithstanding his great age; for he must have been bordering on seventy at the time that he succeeded to the government of Demerara. My intimacy with him had a singular origin.

Krowing that I should spend very little time in the civilised parts of the colony, I had not paid my respects at head quarters after the general had 
succeeded to the government. Prior, however, to my going into the interior, I paid some visits to different friends residing up the river Demerara. About this period, an English gentleman of my acquaintance had been outlawed, on account of a certain bill transaction. It was said that the party who had caused his disgrace had acted fully as much through private pique, as through a love of justice. Indeed, the character of his principal accuser was none so good; and one might have said to him with truth,

"Stamina de nigro vellere facta tibi."

But this man held a high official situation, and it was as the seven-fold shield of Ajax to lim. The unfortunate gentleman (for a gentleman he was in manners and appearance) was skulking up the river Demerara, in order to escape from the colony by the first favourable opportunity. The governor had offered 50()$l$. for his apprehension. To add to his misfortunes, he was sorely afflicted with a liver complaint; and, when he at last fell in with me, he told me that he had gone from place to place for three weeks in quest of me, that I might bleed him, as he dared not entrust himself to a surgeon, on account of the proclamation which was out against him. We were at breakfast, about twenty miles up the river Demerara, at the house of a gentleman who knew how to pity those in distress, when a negro came into the room, and informed us that a tent-boat with four oars was approacling. I looked out of the window, and saw the officers of justice in it. Not a moment was to be lost. I directed our out- 
law to go through the back door into a field of standing canes. But so great was his perturbation, that lie jumped out of the window ; and, in lieu of taking over a bridge close at hand, he ran through a filthy trench, nearly up to the arm-pits in water.

It was not more than half flood tide in the river; and, on this account, the officers could not land at the house without walking up a square $\log$ of wood which had been placed on the mud, and formed part of the stelling, or wharf, for the accommodation of those who land when the water is low. On this log I took my stand, and disputed the passage with the officers of justice. They could not pass without forcing me up to the middle in mud, or making me retrace my steps up the $\log$. When I thought there had been time enough allowed for the fugitive to make his escape, I returned to the house, they following close on my steps, and entering into it immediately after me. Not having succeeded in the object of their search, they returned to the boat, muttering curses in Dutch as they re-crossed the threshold.

The next day a warrant arrived, ordering me to appear immediately at Government House.

Although I did not know the governor personally, I was pretty well acquainted with his character; and I was aware that there was only one way for me to act. So I resolved at once to take him on his weak side, if so it might be called.

On my name being announced he came into the hall. Whilst looking at me full in the face, he exclaimed in a voice too severe to last long: "And so, Sir, you have dared to thwart the law, and to 
put my late proclamation at defiance?" "General," said I, " you have judged rightly ; and I throw myself on your well-known generosity. I had eaten the fugitive's bread of hospitality, when fortune smiled upon him; and I could not find in my heart to refuse him help in his hour of need. Pity to the unfortunate prevailed over obedience to your edict; and had General Carmichael himself stood in the shoes of the deserted outlaw, I would have stepped forward in his defence, and have dealt many a sturdy blow around me, before foreign bloodliounds should have fixed their crooked fangs in the British uniform." "That's brave," said he; and then he advanced to me, and shook me by the hand.

I staid with him about a couple of hours, and told him of my intended expedition, through the forests, to the Portuguese settlements on the Rio Branco; adding that I had already observed the necessary formalities required by law from those who are about to leave the colony. He gave me permission to range through the whole of ci-devant Dutch Guiana for any length of time, and ordered my passport to be made out immediately. It bears his signature, and date of April 16. 1812.

General Carmichael had not been long in his government, before he saw the necessity of striking at the root of numberless corruptions which existed in the different departments, and which his predecessor had not been able to remove, both from want of time and health. Wherefore he set to work in good earnest; and he got the nick.name of Old Hercules, in allusion to that hero's labours in the filthy stable of King Augeus. 
He was very peremptory in his orders. I was one day conversing with him concerning the interior of the country, when an English gentleman came to lodge a complaint against a Dutch lawyer, for detaining in his possession certain monies which he ought to have delivered up. "Are you quite right, Sir, in your story?" said the governor to the English gentleman. "I am, an 't please your Excellency," answered he. "Then go and bring him hither," rejoined the governor. He returned with the lawyer in about half an hour. "Did you recover the money for this gentleman?" asked the governor. "I did," answered the lawyer. "Then why do you not give it to him?" "Because because" - and here he stammered in great agitation; when the governor sternly asked him, "Do you see that lamp-post in front of the window?" "I do." "Then," remarked the governor, "I 'll have you hanged on it, by Saturday night, if you do not refund the money.". The lawyer paid the money on the following day.

But death cut the governor short ere he had half finished his labours. On my return from Europe (whither I had gone for the recovery of my health), I found him buried under the flag-staff at the Fort, in accordance with his own directions.

Whilst I was in the forests, I wrote the following tribute to his memory, and sent it to the editor of the Guiana Chronicle:-

"And what did they call him Old Hercules for? Is not Agamemnon generally the name for a commander-in-chief? I don't know much about these things; but the reason he was surnamed Hercules 
is briefly this:-The public offices emitted a very strong smell: the impositions there had been accumulating for a long time. He had not been a week in the town before the fumes turned him sick at stomach. He vowed he would clear the town of the nuisance, and have all the litter wheeled out, although he should work day and night. This was a second Augean job; and from this he got the name of Hercules.

"Well, and did he set to work in good earnest? He did indeed. He cleared many of the offices to their original pavement; he handled numbers of the tenants in the different departments very roughly; some he hurled neck and crop out of the fattening pen, and others he frightened nearly out of their senses.

"He could not bear the sight of the Dutch lawyers. He told them that their stomachs were as craving as that of the vulture on the liver of Tityus; that they were the scourge of the country; that they were worse to manage than the brazen-footed bulls of old; that they belonged to Celæno; and that, if he only kept his health, he would, ere long, drive them all into Stymphalus.

"Poor, well-intending, much lamented Old Hercules! In the openness of his heart, oftentimes, at table after dinner (which is the very worst place and time for a man to open his mouth on things of consequence), he would talk of his intended plans and operations to those around him. He was too sincere himself to suspect the want of sincerity in some of those who ate his bread and drank his wine. 
They played a double part; and they caused the war which he was carrying on against extortion and corruption to give him more trouble than the besieging of half of the fortified cities in the West Indies would have done.

"However, he still continued to carry on his work for the public good; but his friends could see with concern that his health was declining apace. At length, sickness and anxiety pressed too heavily on his much-enfeebled shoulders. He sunk into the grave, pitied and lamented by every honest man in Demerara."

To General Carmichael, indirectly, I owe one of the best watches that man ever wore. Many of those colonists who held public offices in Demerara had not been over and above scrupulous in their money transactions with the government; and the general had given it out that they should all be summoned, and be made to swear to their accounts. Awongst them was a Dutch gentleman (since dead), in the colonial service, who had still a large slice of conscience left. He told his friends that he was quite aware he could never make out a just balance sheet, but that he would die before he would take a false oath. The affair haunted him day and night, until he could bear it no longer; and he actually proceeded up the river Demerara, to the house of his friend Mr. Edmonstone in Mibiri creek, with the full intention of proceeding through the interior to the far-distant Portuguese or Spanish settlements, as occasion might offer. I was staying with Mr. Edmonstone at the time. As the fugitive 
officer was walking with me in the woods on the following morning, he entered more largely on the plan of his intended escape; and he said he had arranged bis little affairs pretty well before he left the town; but that he had not been able to dispose of his watch, which was nearly new, and which had been made to order by Keating of London, who had charged forty pounds for it. My companion had been very attentive to me formerly, when he was at Government House in the time of Governor Bentinck. Knowing that a friend in need is a friend indeed, I put his watch into my waistcoat pocket, after having returned him his seals, and two rings attached to it, and told him I was his debtor for the sum of sixty guineas.

During the day Mr. Edmonstone received a letter, informing him that the general and his staff would pay him a visit in the course of the week. This information put the already shattered nerves of our friend in a still worse state; for he made no doubt but that the general had got information of his flight. However, I was of a different way of thinking; and I told him to compose himself; that I would look into the affair; and that, worst come to the worst, we could always get him out of the way during the general's visit.

The next afternoon we took a small canoe, and went to Mr. Beaumond's in Waratilla creek, where we passed the night. I had luckily ordered a few troely leaves to be put into the bottom of the canoe in case of rain ; and, as things turned out, they proved of the utmost use; for, actually, as we were 
on our return to Mibiri, just at the mouth of Waratilla creek, we saw the general, and Captains Eyre and Dawson, and Commissary Pittman (three of the best fellows alive), coming up in a tent-boat. I immediately directed my friend to lie flat down in the canoe; and then, like robin redbreast of old, I covered this great babe of the wood with leaves. Having saluted the governor and his company, I ordered the negroes to keep abreast of his boat, in order that we might converse as we went along. Here I had a fine opportunity of pumping him with regard to my friend in the bottom of the canoe. I asked him if he had seen Captain lately. He said, not very lately; and he feared that the captain was sick. I then added, that he was expected at Mr. Edmonstone's; and the general immediately rejoined, that it would give them all exceeding great pleasure to see him, as he was such an excellent fellow. By this I knew that all was right. We accompanied the general's boat up to Mr Edmonstone's ; my friend lying quite still under the troelies, and hearing every word of our conversation. About a couple of hours after our arrival, I left the house for a while, and then returned with my friend, who in the meantime had gone into an out-building. The general shook him cordially by the hand, and asked him when he had left town. He answered that he had been to see an acquaintance in the creek, and had come thus far to pass a day or two with Mr. Edmonstone. Having now proof positive that his plan of self-expatriation was quite unknown to the general, he determined to return 
to Stabroek, where his fears gradually subsided; and after the general's death there was no more talk of bringing the accounts to a public examination.

This was in the spring of 1812 , from which time to the beginning of the year 1825 the Wanderings form a continuation of these memoirs. But as a few interesting occurrences took place in the interval betwixt these dates, I will pen them down in the following pages.

During my expedition for the wourali poison, in the summer of 1812 , General Carmichael had written to Lord Bathurst, to say that $I$ was in the forests; and that, if be wanted a person to conduct an exploring enterprise, he thought that I might be safely recommended to his lordship's notice.

I had returned from the interior broken down with sickness, brought on by being reduced to eat unwholesome food, and by being exposed day and night to the inclemency of the rainy season. The doctors having ordered me to England without loss of time, I took my passage on board the Fame of Liverpool, Captain IVilliams.

During my stay in Stabroek, previous to the vessel's leaving port, the general gave me the colonial dispatches to be delivered to Lord Bathurst, and at the same time he presented me with a warm letter of introduction to his lordship. We had a splendid ball on the eve of our departure. In the ball-room General Carmichael took the opportunity of introducing me to Captain Peake of the Peacock sloop of war, appointed to be our convoy to Barbadoes. 
On the following morning, when we had got up our anchor, Captain Peake came alongside of the Fame, and invited me to stay with him on board the Peacock, until we should reach Barbadoes; adding that, when he had got all the fleet fairly under weigh, he would not fail to send his boat for me.

This, unfortunately, was our last interview. By eleven o'clock it blew a gale of wind; and, as the Fame made a poor hand of it when close hauled, we drifted bodily to leeward, lost sight of the fleet in the evening, and at last barely managed to fetch Grenada, in lieu of making Barbadoes. In the mean time, Captain Peake, having brought his fleet to an anchor in Carlisle Bay, returned to the coast of Guiana, where he fell in with an American man-of-war. She was his superior in men and guns, but not in valour, for our brave captain fought her to the last; and he was cut in two by a cannon ball, just at the time that his own vessel went down. He was held in great esteem by the colonists; and I have heard that they raised a monument to his memory in the church at Stabroek.

The voyage to Europe did not recruit my health. When I had landed in Liverpool, I was unable to proceed to London with the despatches; so I sent them by the mail, and wrote a letter of apology to Lord Bathurst. His lordship returned a very kind answer, and requested that I would repair to London when I had got better of the tertian ague, as he wished me to explore Madagascar.

When I had rallied a little, I proceeded to London, and waited on him. He told me that I should 
have to explore the interior of Madagascar; with permission to visit Monomotapa, and the Sechelles Islands, \&c. ; and that a man-of-war would take me out early in October following. This was in the month of May, 1813. The ague still annoying me cruelly, I wrote to Lord Bathurst, and begged to resign the commission.

Horace once condemned himself for running away, - "relictâ non bene parmulâ." It was for me to have condemned myself too on this occasion; for I never acted so much against my own interest as when I declined to go to Madagascar. I ought to have proceeded thither by all means, and to have let the tertian ague take its chance. My commission was a star of the first magnitude. It appeared after a long night of political darkness, which had prevented the family from journeying onwards for the space of nearly three centuries. I can fancy that it beckoned to me, and that a voice from it said, "Come and serve your country; come and restore your family name to the national calendar, 'from which it has been so long and so unjustly withdrawn; come, and show to the world that conscience, and not crime, has hitherto been the cause of your being kept in the background; come into the national dockyard, and refit your shattered bark, which has been cast on a lee-shore, where merciless wreck-seekers have plundered its stores, and where the patriots of yesterday have looked down upon it with scorn and contempt, and have pronounced it unworthy to bear its country's flag." I ought to have listened to this supposed adviser at 
the time : but I did not; and the star went down below the horizon, to appear no more.

Few people, except those who have been to seek adventures in far distant countries, are aware of the immense advantages of a government commission, especially when the traveller is in our own colonies. With it his way is clear, and his story is already told: every body acknowledges his consequence, and is eager to show him attention. Without it, he is obliged to unfold his object in view at every step: he must fight his own cause, through surrounding difficulties, and lose many a day for want of somebody to take him by the hand. In 1824, I was at St. John's, in the Island of Antigua, and had to attend at a public office prior to $\mathrm{my}$ going on board the mail-boat for Dominica. I had lately arrived from the United States, very much out of health ; and I wore one of those straw hats, with a green riband round it, so common in the republic. The harbour-master, who presided, and outwardly appeared much of a gentleman, eyed me, as I thought, contemptuously on my entering the room. I was right in my conjecture, for he seemed determined to wear out my patience ; and he kept me standing above half an hour, without once asking me to take a seat, although there were plenty of chairs in the room. In returning to the hotel with the captain of the mail-boat, I observed to him how very deficient the harbour-master had been in common courtesy. He replied that, as soon as I had gone out of the door of the office, the harbourmaster stopped him to inquire who I was; and, 
when he had told him that I was an English gentleman, travelling in quest of natural history, he remarked that he had been mistaken in his surmise, for that he had taken me for a damned Yankee.

In the autumn of 1814, as I was shooting with my excellent brother-in-law, Mr. Carr, I had a proof that, although a man may escape with impunity in distant regions, he may stumble on misfortune at home, when he least expects it. My gun went off accidentally. I had just rammed the paper down upon the powder, when the ramrod, which was armed with brass at both ends, passed quite through my fore finger, betwixt the knuckle and the first joint, without breaking the bone; the paper and ignited powder following through the hole, and rendering its appearance as black as soot. I repaired to a tenant's house, and poured warm water plentifully through the wound, until I had washed away the marks of the gunpowder; then collecting the ruptured tendons, which were hanging down, I replaced them carefully, and bound up the wound, not forgetting to give to the finger its original shape as nearly as possible. After this, I opened a vein with the other hand, and took away to the extent of two and twenty ounces of blood. Whilst I am on phlebotomy, I may remark, that I consider inflammation to be the root and origin of almost all diseases. To subdue this at its earliest stage has been my constant care. Since my four and twentieth year, I have been blooded above one hundred and ten times, in eighty of which I have performed the operation on myself with my own 
hand. This, with calomel and jalap mixed together, as a purgative, with the use of rhubarb in occasional cases of dysentery, and with vast and often repeated potations of powdered Peruvian bark, as a restorative, has enabled me to grapple successfully with sickness when I was far away from medical aid. In cases where laudanum was absolutely necessary, I was always extremely cautious, having seen far too many instances in other people of the distressing effects produced by the frequent use of this insidious drug. My severest trials of sickness were those when I had to contend with internal inflammation at the very time that I was labouring under tertian ague. In those cases, the ague had to bear all the burden, for I knew that it was not a mortal complaint; whereas internal inflammation was not to be trifled with for one moment. Under this impression, I would fearlessly open a vein, and would trust to the Peruvian bark, at a later period, to counteract the additional encouragement which I had been forced to give to the ague, through the medium of the lancet. I am now, I think, in as perfect health as man can be. But let me finish the account of my accident. On reaching home, I applied a very large poultice, which was renewed twice every day. The inflammation never extended beyond the knuckles; and I recovered the full use of the finger in due course of time.

Early in the year 1817, an expedition was formed to explore the river Congo, in Africa. I went to London, and requested Sir Joseph Banks to allow me to accompany it as a volunteer. He acceded to 
my wishes. One day, whilst I was in his room, there came a letter to inform him that the steamvessel appointed for the expedition did not answer expectations; for its powers were not considered adequate to make way against the downward stream of the Congo. "Then," exclaimed Sir Joseph, with great emphasis, "the intended expedition will be a total failure;" and, putting his hand upon my shoulder, "My friend," said he, "you shall not go to Africa. There will be nothing but disappointment and misfortune, now that the plan of proceeding by steam cannot be put in execution to the extent which I deem absolutely necessary for the success of the enterprise." He then requested me to prolong my stay in London, and to meet the scientific gentlemen who formed the expedition for a day or two at his house, in order to impart certain instructions to them. I did so; and showed them many things which, I think, could not fail to prove useful* to them in their preparation of specimens for the benefit of natural history. Above all things, I tried to impress upon their minds the absolute necessity of temperance; and I warned them particularly never to sleep in their wet clothes.

I left London for Yorkshire, and from thence went to Liverpool, where I embarked on board the Indian, Captain Balberney, for Pernambuco, in Brazil.

" My dear Sir,

* "Soho Square, Saturday Evening.

"I return your manuscript, with abundant thanks for the very instructive lesson you favoured us with this morning, which far excelled in real utility every thing I have hitherto seen.

"Y Your obliged and faithful 
Whilst I was on the other side of the Atlantic, I read an account in one of the English papers, which stated that the Congo expedition had entirely failed, and that several of the gentlemen whom I had met at the house of Sir Joseph Banks had perished in it.

In the winter of 1817-18, I was in Italy with my friend Captain Alexander of the Navy. During our stay in the eternal city, I fell in with my old friend and schoolfellow, Captain Jones. Many a tree we had climbed together in the last century; and, as our nerves were in excellent trim, we mounted to the top of St. Peter's, ascended the cross, and then climbed thirteen feet higher, where we reached the point of the conductor, and left our gloves on it. After this, we visited the castle of St. Angelo, and contrived to get on to the head of the guardian angel, where we stood on one leg.

As Captain Alexander and myself were returning over Mount Cenis, I fancied that the baggage had broken loose on the top of the carriage ; so I immediately mounted on the wheel to see what was the matter. As bad luck would have it, I came in contact with the window, and smashed the glass: two pieces of the pane, an inch long, penetrated a little above the cap of the left knee, on the inner side, and broke short off. This was at ten o'clock of the night. I put my thumb firmly on the wound, until the captain had brought one of the lamps to bear on it. On seeing the blood flow in a continued stream, and not by jerks, I knew that the artery was safe. Having succeeded in getting out the two pieces of glass with my finger and thumb, I 
bound the wound up with my cravat. Then, cutting off my coat pocket, I gave it to the captain, and directed him to get it filled with poultice, in a house where we saw a light at a distance. The next day a strong fever came on; so we stopped until it had abated, and then we went on again; and stopped again on account of the fever ; and again proceeded, until at last we reached Paris; the wound being in a deplorable state. Here Doctor Marshall, a friend from Demerara, took me under his care until I wa in a state to proceed to England. He showed exquisite skill in his treatment of the wound, and would have done wonders for it had I staid a sufficient length of time with him.

On my arrival in London, Father Scott, of the Society of Jesus, came immediately to my assistance. Having inspected the wound, he took his departure without loss of time, and he brought back with him the celebrated Mr. Carpue; to whose consummate knowledge and incessant attention I owe the preservation of the limb, and probably of life too. The knee continued stiff for nearly two years; but, by constant exercise, and by refusing the aid of a walkingstick, it lost at last all rigidity, and is now as sound as though it had never been injured. I have often thought since, that I should have laid my bones in France, but for the unwearied exertions of my friend Captain Alexander.

In 1824, I caught so severe a cold, by having incautiously taken a hot bath in the city of New York, that all the skill of Doctor Hossack could not have saved me from consumption, had I not, at his 
urgent entreaty, taken myself off to a warmer climate. I was bled eight times, and I lived for six weeks on little more than white bread and tea. It was during my stay in the United States that I was fortunate enough to make the acquaintance of $\mathrm{Mr}$. Ord of Philadelphia, that excellent naturalist, and elegant biographer of poor Wilson the ornithologist. In 1825, the dismally bleak and cold weather which we experienced in the Channel was much against me; and my old foe, an affection of the lungs, made its appearance, and seemed determined to have its own way. The late much lamented Doctor Gilby of Wakefield grappled with it for six months, and at last succeeded in restoring me to perfect health, which I have enjoyed ever since.

In 1829, I became the happiest man in the world; but it pleased Heaven to convince me that all felicity here below is no more than a mere illusive transitory dream; and I bow submissive to its adorable decrees. I am left with one fine little boy, who "looks up to me for light;" and I trust that I shall succeed in imparting it to him; for my sister, Mrs. Carr, and her invaluable husband, together with his aunts, Miss Edmonstone, and Miss Helen Edmonstone, know no bounds in their affection for him, and in their good offices to myself, who stand so much in need of them.

Since the year 1825, I have not been in the transatlantic forests, but have merely sauntered from time to time in Belgium, in Holland, and in Germany, with my above-mentioned sisters-in-law. I -was in Belgium during the revolution for real liberty 
in religious matters; and I wrote a paper for the Examiner, in which I predicted that the game would shortly be up for ever with the Dutch flag. I went into the large square at Bruges to see the Belgians engage their enemies. As the balls whistled on all sides, I thought I might as well live to see the row another day; so, observing a door half open, I felt much inclined to get under cover; but, just as $\mathrm{I}$ arrived at the threshold, a fat old dame shut the door full in my face. Thank you, old lady, said I: "Felix quam faciunt aliena pericula cautam." The reader, I fear, is now pretty well tired with these Memoirs. They will soon be concluded. He cannot fail to have discovered what has been my ruling propensity through life. I crave a little more indulgence, as I am anxious to say a few words relative to the Wanderings.

Wouralia, the ass mentioned in that work, is still alive, and in good health. Supposing that she was in her third year at the time that she was sent to me from London, by the present Duke of Northumberland, then Lord Percy, she must now be seven and twenty years old. She was inoculated with the wourali poison, and restored to health by artificial respiration. Mr. Sewell is satisfied that this Indian poison is capable of curing the dreadful malady caused by the bite of a mad dog. Would it not be well to make the experiment on some person who is just about to sink under the virulence of that disease, and when the case has been declared utterly hopeless by the faculty who surround the bed of the dying man? I have a good supply of the real ori- 
ginal. Not long ago, a gentleman was here, and begged a small portion of it, as he said that the savans of Paris had lately tried some Indian poison, but without effect. I complied with his request; and, on opening the wax in which the poison is enclosed, I found it quite soft, and ready for use; although it had not been looked at for above twenty years. If any farmer should have one of his herd bitten by a mad dog, I would willingly repair to the spot, and try the effect of the poison on the animal.

I am fully aware that certain statements in the Wanderings have procured me the honour of being thought nearly connected with the Munchausen family. Unenviable is the lot of him whose narratives are disbelieved merely for want of sufficient faith in him who reads them. If those who have called my veracity in question would only have the manliness to meet me, and point out any passsage in the book which they consider contradictory or false, I would no longer complain of unfair treatment. If they can show that I have deviated from the line of truth in one single solitary instance, I will consent to be called an impostor; and then may the Wanderings be trodden under foot, and be forgotten for ever.

Some people imagine that $I$ have been guilty of a deception in placing the nondescript as a frontispiece to the book. Let me assure these worthies that they labour under a gross mistake. I never had the slightest intention to act so dishonourable a part. I purposely involved the frontispiece in mystery, on account of the illiberality 
which I experienced from the Treasury* on my return from Guiana.

I had spent many years in trying to improve the very defective process universally followed in preparing specimens for museums. The reader will see by the letter signed Lushington that $I$ was sentenced to pay pretty handsomely for my exertions.

Stung with vexation at the unexpected contents of that peremptory letter, and annoyed at the detention of my collection, I determined not to communicate to the public the discovery which $I$ had made of preparing specimens upon scientific principles; but, in order to show what I had done, I placed the nondescript in the Wanderings; hoping that its appearance would stimulate to investigation those who are interested in museums. Should there be any expression in the Wanderings, by which the reader may be led to imagine that $I$ wish to pass off this extraordinary thing either for the head and shoulders of a man, "os homini sublime ;" or for

\section{"Gentlemen,}

* "Treasury Chambers, May 18th.

"The Lords Commissioners of His Majesty's Treasury, having had under their consideration your report of the 10th, on the application of Mr. Charles Waterton, for the delivery, duty free, of some birds, quadrupeds, reptiles, and insects, collected by him in Guiana, and recently imported from Demerara, I have it in command to acquaint you that my Lords have informed Mr. Waterton that, if he will specify the articles which he intends to. give to public institutions, my Lords will not object to their being delivered duty free; but that, with regard to the specimens intended for bis own or any private collection, they can only be delivered on payment of the ad salorem duty of 20 per cent.; and $I$ am to desire you will give the necessary directions to your officers at Liverpool, in conformity thereto.

"Commissioners of Customs."

$$
\text { "I am, \&c. "Signed) }
$$

J. R. Luenisctos, 
those of an ape, "Simia, - quam similis, turpissima bestia nobis';" it is my earnest desire that the said expression may be considered null and void. I have no wish whatever that the nondescript should pass for any other thing than that which the reader himself should wish it to pass for. Not considering myself pledged to tell its story, I leave it to the reader to say what it is, or what it is not.

Some of my encounters with wild beasts may appear hair-breadth escapes, and very alarming things, to readers at their own fireside; but to me, in the forest, they appeared not so.

We are told that death itself is not heeded when the battle rages. This I believe; for, when honour, fame, or duty, urge a determined man forwards, I apprehend that he knows not what it is to fear. Thus, the soldier marches boldly on, even to the cannon's mouth ; the fox-hunter, in conscious pride, flies over the five-barred gate; and half way down Dover's cliff "hangs one that gathers samphire." But, I ask, would a "pampered menial" storm the deadly breach? would a gouty alderman descend the rock of Ailsa, based by the roaring ocean, in quest of sea-fowls' eggs? No. Their habits, and their ailments, would disable or prevent them; and, probably, nothing could induce them to face the apparent danger. Now, as for myself, I was well fitted out for adventures. I went expressly to look for wild beasts ; and, having found them, it would have been impossible for me to have refrained from coming in actual contact with them.

I have only to repeat, that I particularly request 
those readers of the Wanderings who may still doubt my word to meet me in person, and then show me any passage in the book which they may suspect to deviate from the truth. It will give me pleasure to enter fully into the point in question; and I shall not have the slightest doubt of being able to convince them that they are wrong in their surmises. If they should refuse to comply with this my reasonable and just request, and still determine to consider me a disciple of the celebrated baron, then to them I say, "Gentlemen, fare ye well. In my conscience, I have laboured hard to please you, and to consult your taste; but I find that I have lost my time, and, I may add, my patience too. I humbly crave your forgiveness for having offered you food, which has proved so very unpalatable to your stomachs. I will learn wisdom for the time to come; and I promise you that I will not throw my jewels to the sty a second time."

So far for the Wanderings. Most part of the work was written in the depth of the forest, without the help of books, or the aid of any naturalist. I could not refrain from making a few observations on it ere I concluded these Memoirs, - Memoirs, by the way, from the pen of a private rover. Had our religion not interfered with our politics, my early days would probably have been spent in the service of my country. Then, no doubt, there would have been matter in these Memoirs much more interesting to the reader than that which is now submitted to his perusal.

I could never comprehend how a government, 
which professes to be the most tolerant of all governments in things appertaining to religion, should have visited millions of its subjects with the severest penalties, for two long centuries and a half, merely because they refused to abandon the creed of their ancestors. Neither can I comprehend how a government can have the consummate assurance to enforce payment to the church by law established, when it is a well-known fact in history (see the act of parliament 1st \& $2 \mathrm{~d}$ of Mary, chap. 8.) that the very founders of this law-church did confess, in full and open parliament, that they had declined from the unity of Christ's church, and had a long while wandered and strayed abroad; and that they acknowledged their own errors, and declared themselves very sorry and repentant of the schism and disobedience committed by them in this realm against the See Apostolic. Again, can anything be more unjust and despicable than the custom of preaching an annual sermon against us on the 5th of November? This year, it fell on a Sunday; and, upon that sacred day, many were the persons who put charity behind the pulpit, and then, in front of it, held up the bugbear popery, in so terrific a point of view, that numbers of old women were nearly frightened into hysterics. However, I think I may venture to assure their reverences that $I$, for one, will never use gunpowder in an unlawful way. I had much rather see them walk soberly along, and keep possession of their usurped pulpits for a little while longer, than hear of them being blown up sky-high by the unjustifiable application of prepared charcoal and saltpetre. 
I beg to draw the attention of their reverences to the following ode, which I composed some few years ago, expressly for the 5 th of November; most appropriately termed Cecil's Holiday. In it their reverences cannot fail to observe that my mode of dealing with our adversaries differs very widely from that adopted by their old friend Guy the detonator.

\section{ODE.}

Pro his oro, qui elegerunt

Falsam fidem, et fregerunt

Quam Majores docuerunt.

Et qui, fracto Dei altare.

Ausi loco ejus dare

* Mensam quæ non potest stare.

Qui, et oves occidebant, Atque collo suspendebant

Duces gregis qui manebant.

Caput fidei qui fecerunt Regem; opes et dederunt Illis, qui nil meruerunt.

A nimabus, qui suorum

Preces negant defunctorum;

Neque coetus Angelorum

Colunt. Pro his oro quoque,

Qui Calvino, Lutheroque

Credunt, Joan-Southcotoque.

Habeant hi claram lucem,

Ut amissam cernant crucem,

Et agnoscant Papam ducem.

* The creed-reformers had hot disputes amongst themselves, for many years, concerning the altar. At last they determined that it should be called a table, and not an altar. 
Tum pax undique florebit,

Neque erit qui lugebit,

Aut Guy-fauxi vim timebit.

TRANSLATroN.

I PRAY for those who now have got

A creed infected with the rot, And wickedly have set at nought

That which our ancestors had taught.

I pray for those who, having thrust

Our boly altars in the dust,

Defiled the places where they stood

With crazy tables formed of wood.

I pray for those who, having slain

Our flocks that grazed the peaceful plain,

Did force their pastoral defenders

Into Jack Ketch's hemp suspenders.

I also pray for those who made

A tyrant king the Church's head;

And let bim waste our sacred treasures,

'Mid rogues and knaves, in filthy pleasures.

I pray for those who have a dread

Of supplications for the dead,

And never offer up a prayer

For their good Angel-guardian's care.

Again, for those I often pray,

Who tread in Luther's crooked way;

Or Calvin trust, or seek salvation

In Mrs. Southcote's proclamation.

May these a steady light obtain,

To find the long-lost cross again ;

And place their faith, and future hope,

Under the guidance of the Pope. 
Then peace will flourish all around, And none in sorrow shall be found;

Nor need we fear a repetition

Of Guy's unlucky expedition.

When I reflect that the faith of my ancestors has been most cruelly assailed for centuries, by every man in power, from the Prime Minister of England down to the county magistrate; when I see it rising again triumphant in every part of the empire; and when I observe multitudes, in every rank of life, returning to its consoling communion, I call to mind, with infinite delight, those beautiful verses of Dryden :-

"A milk-white hind, immortal and unchanged, Fed on the lawns, and in the forests ranged. Without unspotted, innocent within, She fear'd no danger, for she knew no sin. Yet had she oft been chased with horns and hounds, And Scythian shafts, and many-winged wounds Aim'd at her heart; was often forced to fly, And doom'd to death, though fated not to die."

I have made no mention of my political feelings in these Memoirs. My politics, indeed, claim little notice. Being disabled by Sir Robert Peel's Bill from holding even a commission of the peace, I am like a stricken deer, walking apart from the rest of the herd. Still I cannot help casting a compassionate eye on poor Britannia, as she lies on her bed of sickness. A debt of eight hundred millions of pounds sterling (commenced by Dutch William of glorious memory) is evidently the real cause of her distressing malady. It is a fever of the worst 
kind : it is a disorder of terrible aspect. It is a cancer, so virulent, so fetid, and so deeply rooted withal, that neither Doctor Whig, nor Doctor Tory, nor even the scientific hand of Mr. Surgeon Radical, can give any permanent relief to the suffering patient. Alas, poor Britannia! it grieves my heart to see so fine a personage reduced to such a state. Thank Heaven! we Catholics have had no hand in thy misfortunes. They have come from another quarter, where thy real enemies have had all their own way, and have played the game so sadly to thy cost.

Here I terminate these Memoirs; and I put away the pen, not to be used again, except in self-defence. Thus a musician of old (tired, no doubt, with scraping) hung his fiddle on the wall, and said, -

"Barbiton, hic paries habebit."

Charles Waterton.

Walton Hall, December 30. 1837. 



\section{ESSAYS, \&c.}

ON

\section{N A T URAL HISTORY.}

REMARKS ON PROFESSOR RENNIE'S EDITION OF MONTAGU'S ORNITHOLOGICAL DICTIONARY.

"IT is admitted by all the naturalists already quoted, that the nest in question (grebe's) is built on moist ground, if not actually touching the water, and that part at least of the materials consist of moist water plants. Now, it is indispensable to hatching, that the eggs be kept at a high temperature, and not be suffered to cool for a moment. The natural heat of the bird itself is sufficient for this purpose, without the heat of fermentation, erroneously supposed by Pennant; but if she quits them for a moment, to go in pursuit of food, or to withdraw the attention of an intruding water-spaniel, or a prying naturalist, their near vicinity to moist plants, or to water, would certainly prove fatal to the embryo chicks. In order, then, to prevent the brood from being destroyed by cold, the careful bird covers the eggs with a quantity of dry hay, to keep them warm till her return."

When the worthy professor wrote the abovequoted passage, I am sure that he had not the least doubt but that it was correct. Nine tenths of his readers would be of the same opinion with him. 
The errors it contains can only be accounted for on the score that our professor, like many other naturalists of ligh note and consideration, has spent more of his time in books than in bogs. His deficiency in bog-education is to be lamented; for such an education would have been a great help to him in his ornithological writings. For my own part, I must own, that I have been more in bogs than amongst books; and have for years wandered "per loca senta situ," where, it is easy for the reader to imagine, that I must have had many corporal misadventures, and at the same time acquired some mental improvement.

After this statement, I trust that the professor will not take it amiss if I do not agree with him in all his notions on waterfowl incubation. Many writers on natural history, on account of their situation in life, can only attempt to clear up doubts by means of theory. Others, again, who have had practice, have it in their power to adduce facts. Truth is the great object which all strive to reach. "Omnes eodem cogimur."

Let us now go to the marsh, and find a waterfowl's nest, with the old bird sitting on eggs containing embryo chicks. We will drive the bird gently off the nest, and we will stay full two hours near the place, to prevent the return of the bird. At the end of the two hours we will go away, and I will engage that the old bird will come back to her nest, and hatch the eggs which have been left uncovered all this time. This being the case, how stands the professor's speculation, that the vicinity 
of the nest to moist plants, or to water, would certainly prove fatal to the embryo chicks, were the bird to quit the eggs for a moment unless she covered them with dry hay?

In 1826, I was helping a man to stub some large willows near the water's edge. There was a waterlien's nest at the root of one of them. It had seven eggs in it. I broke two of them, and saw that they contained embryo chicks. The labourer took up part of the nest, with the remaining five eggs in it, and placed it on the ground, about three yards from the spot where we had found it. We continued in the same place for some hours afterwards, working at the willows. In the evening, when we went away, the old waterhen came back to the nest. Having no more occasion for the labourer in that place, ${ }^{\circ}$ took the boat myself the next morning, and saw the waterhen sitting on the nest. On approaching the place, I observed that she had collected a considerable quantity of grass and weeds; and that she had put them all around the nest. A week after this I went to watch her, and saw she had hatched; and, as I drew nearer to her, she went into the water, with the five little ones along with her.

Birds which, on voluntarily leaving their nest, cover all their eggs containing embryo chicks, equally cover those eggs before they contain an embryo chick, that is, before they begin to sit. Now, during the period of laying, the old bird seldom returns to the nest above once in twenty-four hours; and then only to lay an egg, and go away 
again. Are the eggs, then, covered these four and twenty hours to keep them warm? Put your hand upon them, and you will find them "cold as any stone." Nay, more, you shall take one of these eggs, which you find covered before the bird begins to sit, and you shall immerse it for four and twenty hours in water; and if you put it back into the nest before the bird begins to sit, you will find that she will hatch it at the same time with the rest of the eggs.

If, then, this egg will produce a bird after being four and twenty hours in the water; and if the other eggs (in the case of the waterhen) containing embryo chicks will produce birds after being left uncovered some hours by the mother, may we not venture to hazard a conjecture that the professor, somehow or other, has not exactly entered into the real notions of waterfowl for covering their eggs with dry hay when they leave the nest, both before and after they begin to sit?

I will here add an observation. "The Dabchick," says our professor, " covers its eggs to keep them warm; for the vicinity of the nest to moist plants, or to water, would certainly prove fatal to the embryo chicks, were she to leave the eggs for a moment without covering them." But the wagtail will build her nest within a foot of the water, and yet she never covers the eggs when she leaves her nest. Now, the shell of the wagtail's egg being much thinner than that of the dabchick, might one not be apt to infer that the egg of the wagtail would suffer sooner from cold than the egg of the dabchick? 
One is rather at a loss to know how the professor discovered that the eggs of the dabchick are affected by their near vicinity to moist plants or to water, unless they are covered either by the old bird, or with dry hay. The dabchicks raise their nests upon a superstructure far above watermark. Now, the height of the nest from the water, and the thickness of the materials with which it is lined, will effectually secure it from damp. Put your hand into the nest of the next dabchick which you discover, and you will find that it is quite dry.

The waterhen is another bird which generally builds its nest upon the sedges and rushes; and it carefully covers its eggs, both before and after it begins to sit: but sometimes this bird makes its nest in a place warm and comfortable.

In 1828, I formed a little structure, about a foot square, on a dry island. It was intended for a duck; and it was built of brick and mortar. The top was well secured with a flag; and there was a hole left in the side, just large enough to let in a duck. Some dry hay was put into the place, to serve as a nest for the duck. But it so happened that the duck had to go somewhere else to lay her eggs; for a waterhen took possession of this little structure; and I found her eggs covered with hay, both before and after she began to sit. Did she do this to keep the eggs warm, lest their vicinity to the water should prove fatal to the embryo chicks?

In 1826, a wild duck made its nest within two yards of the water's edge, and upon ground not more B 3 
than three inches above watermark. She covered her eggs, both before and after she began to sit.

Another wild duck, in this same year, made her nest in the thick ivy, upon the top of an old ruin, full $18 \mathrm{ft}$. from the water; and she regularly did the same thing with regard to her eggs. Did the last duck do this to preserve the eggs from the fatal influence of the vicinity to water, full $18 \mathrm{ft}$. below her, with a thick wall intervening?

While this duck on the ruin carefully covered her eggs every time she voluntarily left the nest, a chaffinch, a wagtail, and a ringdove, building in the ivy of the same ruin, never covered their eggs at all on leaving the nest; while in deep holes of the same ruin, a barn owl, a jackdaw, a starling, a house sparrow, and a redstart, had their eggs safely sheltered from wind, and cold, and rain.

I offer these facts and observations to young naturalists as a kind of Ariadne clew, to help them through the labyrinth of waterfowl incubation. Should they not suffice, all I can do is, to recommend the bewildered ornithologist to go to that far eastern country where the vizier of Sultan Mahmoud understands the language of birds. Though, possibly, the vizier may now be dead, still his surprising knowledge has, no doubt, descended to his offspring; just in the same way as a hereditary knack at legislation goes down from father to son in our Fnglish peerage. We are told that -

"Fortes creantur fortibus et bonis;

Est in juvencis, est in equis patrum.

Virtus." 
THE HABITS OF THE BARN OWL, AND THE BENEFITS IT CONFERS ON MAN.

THIs pretty aerial wanderer of the night often comes into my room; and after flitting to and fro, on wing so soft and silent that he is scarcely heard, he takes his departure from the same window at which he had entered.

I own I have a great liking for this bird; and I have offered it hospitality and protection on account of its persecutions, and for its many services to me, - I say services, as you will see in the sequel. I wish that any little thing I could write or say might cause, it to stand better with the world at large than it has hitherto done: but I have slender hopes on this score; because old and deep-rooted prejudices are seldom overcome; and when I look back into the annals of remote antiquity, I see too clearly that defamation has done its worst to ruin the whole family, in all its branches, of this poor, harmless, useful friend of mine.

Ovid, nearly two thousand years ago, was extremely severe against the owl. In his Metamorphoses, he says : -

"Fœdaque fit volucris, venturi nuncia luctus,

Ignavus bubo, dirum mortalibus omen."

In his Fasti he openly accuses it of felony :-

"Nocte volant, puerosque petunt nutricis egentes." 
Lucan, too, has hit it hard :-

“Et lætæ jurantur aves, bubone sinistro :"

and the Englishman who continued the Pharsalia says -

"Tristia mille locis Stygius dedit omina bubo."

Horace tells us, that the old witch Canidia used part of the plumage of the owl in her dealings with the devil :

"Plumamque nocturnæ strigis."

Virgil, in fine, joined in the hue and cry against this injured family : -

"Solaque culminibus ferali carmine bubo

Sæpe queri, et longas in fletum ducere voces."

In our own times we find that the village maid cannot return home from seeing her dying swain, without a doleful salutation from the owl :-

"Thus homeward as she hopeless went, .

The churchyard path along,

The blast grew cold, the dark owl scream'd

Her lover's funeral song."

Amongst the numberless verses which might be quoted against the family of the owl, I think I only know of one little ode which expresses any pity for it. Our nursery maid used to sing it to the tune of the Storm, "Cease rude Boreas, blust'ring railer." I remember the first two stanzas of it : -

" Once I was a monarch's daughter,

And sat on a lady's knee ;

But am now a nightly rover,

Banish'd to the ivy tree. 
"Crying, hoo, hoo, hoo, hoo, hoo, hoo,

Hoo, hoo, hoo, my feet are cold!

Pity me, for here you see me,

Persecuted, poor, and old."

I beg the reader's pardon for this exordium. I have introduced it, in order to show how little chance there has been, from days long passed and gone to the present time, of studying the haunts and economy of the owl, because its unmerited bad name has created it a host of foes, and doomed it to destruction from all quarters. Some few, certainly, from time to time, have been kept in cages and in aviaries. But nature rarely thrives in captivity, and very seldom appears in her true character when she is encumbered with chains, or is to be looked at by the passing crowd through bars of iron. However, the scene is now going to change; and I trust that the reader will contemplate the owl with more friendly feelings, and quite under different circumstances. Here, no rude schoolboy ever approaches its retreat; and those who once dreaded its diabolical doings are now fully satisfied that it no longer meddles with their destinies, or has any thing to do with the repose of their departed friends. Indeed, human wretches, in the shape of body-snatchers, seem here in England to have usurped the office of the owl in our churchyards; " et vendunt tumulis corpora rapta suis."

Up to the year 1813, the barn owl had a sad time of it at Walton Hall. Its supposed mourn- 
ful notes alarmed the aged housekeeper. She knew full well what sorrow it had brought into other houses when she was a young woman; and there was enough of mischief in the midnight wintry blast, without having it increased by the dismal screams of something which people knew very little about, and which every body said was far too busy in the churchyard at night-time. Nay, it was a well-known fact, that if any person were sick in the neighbourbood, it would be for ever looking in at the window, and holding a conversation outside with somebody, they did not know whom. The gamekeeper agreed with her in everything she said on this important subject; and he always stood better in her books when he had managed to shoot a bird of this bad and mischievous family. However, in 1813, on my return from the wilds of Guiana, having suffered myself, and learned mercy, I broke in pieces the code of penal laws which the knavery of the gamekeeper and the lamentable ignorance of the other servants had hitherto put in force, far too successfully, to thin the numbers of this poor, harmless, unsuspecting tribe. On the ruin of the old gateway, against which, tradition says, the waves of the lake have dashed for the better part of a thousand years, I made a place with stone and mortar, about $4 \mathrm{ft}$. square, and fixed a thick oaken stick firmly into it. Huge masses of ivy now quite cover it. In about a month or so after it was finished, a pair of barn owls came and took up their abode in it. I threatened to strangle the keeper if ever, after 
this, he molested either the old birds or their young ones; and I assured the housekeeper that I would take upon myself the whole responsibility of all the sickness, woe, and sorrow that the new tenants might bring into the Hall. She made a low courtesy; as much as to say, "Sir, I fall into your will and pleasure:" but I saw in her eye that she had made up her mind to have to do with things of fearful and portentous shape, and to hear many a midnight wailing in the surrounding woods. I do not think that, up to the day of this old lady's death, which took place in her eighty-fourth year, she ever looked with pleasure or contentment on the barn owl, as it flew round the large sycamore trees which grow near the old ruined gateway.

When I found that this first settlement on the gateway had succeeded so well, I set about forming other establishments. This year I have had four broods, and I trust that next season I can calculate on having nine. This will be a pretty increase, and it will help to supply the place of those which in this neighbourhood are still unfortunately doomed to death, by the hand of cruelty or superstition. We can now always have a peep at the owls, in their habitation on the old ruined gateway, whenever we choose. Confident of protection, these pretty birds betray no fear when the stranger mounts up to their place of abode. would here venture a surmise, that the barn owl sleeps standing. Whenever we go to look at it, we invariably see it upon the perch, bolt upright; and often with its eyes closed, apparently 
fast asleep. Buffon and Bewick err (no doubt, unintentionally) when they say, that the barn owl snores during its repose. What they took for snoring was the cry of the young birds for food. I had fully satisfied myself on this score some years ago. However, in December 1823, I was much astonished to hear this same snoring kind of noise, which had been so common in the month of July. On ascending the ruin, I found a brood of young owls in the apartment.

Upon this ruin is placed a perch, about a foot from the hole at which the owls enter. Sometimes, at mid-day, when the weather is gloomy, you may see an owl upon it, apparently enjoying the refreshing diurnal breeze. This year (1831) a pair of barn owls hatched their young, on the 7 th of September, in a sycamore tree, near the old ruined gateway.

If this useful bird caught its food by day*, instead of hunting for it by night, mankind would have ocular demonstration of its utility in thinning the country of mice; and it would be protected, and encouraged, everywhere. It would be with us what the ibis was with the Egyptians. When it has young, it will bring a mouse to the nest about every twelve or fifteen minutes. But, in order to have a proper idea of the enormous quantity of mice which this bird destroys, we must examine the pellets which it ejects from its stomach in

* Though the barn owl usually hunts during the night, still $I$ have repeatedly seen it catching mice in the daytime, even when the sun shone bright.-C. W. 
the place of its retreat. Every pellet contains from four to seven skeletons of mice. In sixteen months from the time that the apartment of the owl on the old gateway was cleaned out, there has been a deposit of above a bushel of pellets.

The barn owl sometimes carries off rats. One evening I was sitting under a shed, and killed a very large rat, as it was coming out of a hole, about ten yards from where I was watching it. I did not go to take it up, hoping to get another shot. As it lay there, a barn owl pounced upon it, and flew away with it.

This bird has been known to catch fish. Some years ago, on a fine evening, in the month of July, long before it was dark, as I was standing on the middle of the bridge, and minuting the owl by my watch, as she brought mice into her nest, all on a sudden she dropped perpendicularly into the water. Thinking that she had fallen down in epilepsy, my first thoughts were to go and fetch the boat; but before I had well got to the end of the bridge, I saw the owl rise out of the water with a fish in her claws, and take it to the nest. This fact is mentioned by the late much revered and lamented Mr. Atkinson of Leeds, in his Compendium, in a note, under the signature of W., a friend of his, to whom I had communicated it a few days after I had witnessed it.

I cannot make up my mind to pay any attention to the description of the amours of the owl by a modern writer; at least the barn owl plays off no buffaoneries here, such as those which he describes: 
An owl is an owl all the world over, whether under the influence of Momus, Venus, or Diana.

When farmers complain, that the barn owl destroys the eggs of their pigeons, they lay the saddle on the wrong horse. They ought to put it on the rat. Formerly I could get very few young pigeons till the rats were excluded effectually from the dovecot. Since that took place, it has produced a great abundance every year, though the barn owls frequent it, and are encouraged all around it. The barn owl merely resorts to it for repose and concealment. If it were really an enemy to the dovecot, we should see the pigeons in commotion as soon as it begins its evening flight; but the pigeons heed it not: whereas, if the sparrow hawk or hobby should make its appearance, the whole community would be up at once; proof sufficient that the barn owl is not looked upon as a bad, or even a suspicious, character by the inhabitants of the dovecot.

Till lately, a great and well-known distinction has always been made betwixt the screeching and the hooting of owls. The tawny owl is the only owl which hoots; and when I am in the woods after poachers, about an hour before daybreak, I hear with extreme delight its loud, clear, and sonorous notes, resounding far and near through hill and dale. Very different from these notes is the screech of the barn owl. But Sir William Jardine informs us, that this owl hoots; and that he has shot it in the act of hooting. This is stiff authority; and I believe it because it comes from the 
pen of Sir William Jardine. Still, however, methinks that it ought to be taken in a somewhat diluted state; we know full well that most extraordinary examples of splendid talent do, from time to time, make their appearance on the world's wide stage. Thus, Franklin brought down fire from the skies:- "Eripuit fulmen cœlo, sceptrumque tyrannis." Paganini has led all London captive, by a single piece of twisted catgut:- "Tu potes reges comitesque stultos ducere." Leibnitz tells us of a dog in Germany that could pronounce distinctly thirty words. Goldsmith informs us that he once heard a raven whistle the tune of the "Shamrock," with great distinctness, truth, and humour. With these splendid examples before our eyes, may we not be inclined to suppose that the barn owl which Sir William shot, in the absolute act of hooting, may have been a gifted bird, of superior parts and knowledge (una de multis, as Horace said of Miss Danaus), endowed, perhaps, from its early days with the faculty of hooting, or else skilled in the art by having been taught it by its neighbour, the tawny owl? I beg to remark, that though I unhesitatingly grant the faculty of hooting to this one particular individual owl, still I flatly refuse to believe that hooting is common to barn owls in general. Ovid, in his sixth book Fastorum, pointedly says that it screeched in his day :-

"Est illis strigibus nomen; sed nominis hujus Causa, quod horrendâ stridere nocte solent." 
The barn owl may be heard shrieking here perpetually on the portico, and in the large sycamore trees near the house. It shrieks equally when the moon shines and when the night is rough and cloudy; and he who takes an interest in it may here see the barn owl the night through when there is a moon; and he may hear it shriek when perching on the trees, or when it is on wing. He may see it and hear it shriek, within a few yards of him, long before dark; and again, often after daybreak, before it takes its final departure to its wonted restingplace.

I am amply repaid for the pains I have taken to protect and encourage the barn owl; it pays me a hundred-fold by the enormous quantity of mice which it destroys throughout the year. The servants now no longer wish to persecute it. Often, on a fine summer's evening, with delight I see the villagers loitering under the sycamore trees longer than they would otherwise do, to have a peep at the barn owl, as it leaves the ivy-mantled tower: fortunate for it, if, in lieu of exposing itself to danger, by mixing with the world at large, it only knew the advantage of passing its nights at home; for here

"No birds that haunt my valley free

To slaughter I condemn;

Taught by the Power that pities me,

I learn to pity them." 


\section{ON THE FACULTY OF SCENT IN THE} VULTURE.

"Et truncas inhonesto vulnere nares." FEneid. lib. vi.

I NEvER thought that I should have lived to see this bird deprived of its nose. But in the third number of Jameson's Journal, a modern writer has actually given "An account of the habits of the Turkey Buzzard (Vultur Aura), with a view of exploding the opinion generally entertained of its extraordinary power of smelling;" and I see that a gentleman in the Magazine of Natural History, vol. iii. p. 449. gives to this writer the honour of being the first man who, by his " interesting treatise," caused the explosion to take place.

I grieve from my heart that the vulture's nose has received such a tremendous blow; because the world at large will sustain a great loss by this sudden and unexpected attack upon it. Moreover, I have a kind of fellow-feeling, if I may say so, for this noble bird. We have been for years together in the same country; we have passed many nights amongst the same trees; and though we did not frequent the same mess, (for "de gustibus non est disputandum," - and I could not eat rotten venison, as our Englisl epicures do,) still we saw a great deal of each other's company.

Sancho Panza remarks, that there is a remedy for every thing but death. Now, as the vulture has not been killed by the artillery of this modern writer in Jameson's Journal, but has only had its nose carried 
away by an explosion, I will carefully gather up the shattered olfactory parts, and do my best to restore them to their original shape and beautiful proportions. In repairing the vulture's nose, I shall not imitate old Taliacotius, who, in times long past and gone, did

"from

The brawny part of porter's bum

Cut supplemental noses, which

Would last as long as parent breech!"

but I will set to work upon my own resources, and then the reader shall decide whether the vulture is to have a nose or to remain without one.

We all know what innumerable instances there are, in every country, of the astonishing powers of scent in quadrupeds. Thus, the bloodhound will follow the line of the deer-stealer hours after he has left the park; and a common dog will ferret out his master in a room, be it ever so crowded. He is enabled to do this by means of the well-known effluvium which, proceeding from his master's person, comes in contact with his olfactory nerves. A man even, whose powers of scent are by no means remarkable, will sometimes smell you a putrid carcass at a great distance. Now, as the air produced by putrefaction is lighter than common air, it will ascend in the atmosphere, and be carried to and fro through the expanse of heaven by every gust of wind. The vulture, soaring above, and coming in contact with this tainted current, will instinctively follow it down to its source, and there find that which 
is destined by an all-wise Providence to be its support and nourishment.

I will here bring forward the common vulture of the West Indies, the Vultur Aura of Guiana, the king of the vultures of Terra firma, and the vulture which is found in European Andalusia. I am intimately acquainted with all these useful scavengers; and $I$ have never known any of them to kill the food upon which they feed; or when they are in a complete state of nature, free from the restraint or allurements of man, ever feed upon that which was not putrid. Having slain the large serpent mentioned in the Wanderings, though I wished to preserve the skeleton, still I preferred to forego the opportunity, rather than not get the king of the vultures. I called Daddy Quasshi, and another negro, and we carried the body into the forest. The foliage of the trees where we laid it was impervious to the sun's rays, and had any vultures passed over that part of the forest, I think I may say with safety that they could not have seen the remains of the serpent through the shade. For the first two days not a vulture made its appearance at the spot, though I could see here and there, as usual, a Vultur Aura gliding, on apparently immovable pinion, at a moderate height, over the tops of the forest trees. But during the afternoon of the third day, when the carcass of the serpent had got into a state of putrefaction, more than twenty of the common vultures came and perched upon the neighbouring trees, and the next morning, a little after six o'clock, I saw a magnificent king of the vultures. 'There was a stu- 
pendous Mora tree* close by, whose topmost branch had either been dried by time or blasted by the thunder-storm. Upon this branch I killed the king of the vultures, before he had descended to partake of the savoury food which had attracted him to the place. Soon after this another king of the vultures came, and after he had stuffed himself almost to suffocation, the rest pounced down upon the remains of the serpent, and stayed there till they had devoured the last morsel.

I think I mentioned in the Wanderings, that I do not consider the Vultur Aura gregarious, properly so speaking; and that I could never see it feeding upon that which was not putrid. Often when I had thrown aside the useless remains of birds and quadrupeds after dissection, though the Vultur Aura would be soaring up and down all day long, still it would never descend to feed upon them, or to carry them off, till they were in a state of putrefaction.

Let us here examine the actions of this vulture a little more minutely. If the Vultur Aura, which, as I have said above, I have never seen to prey upon living animals, be directed by its eye alone to the object of its food, by what means can it distinguish a dead animal from an animal asleep? or how is it

* "The Mora, in Guiana, is a lofty timber tree, the topmost branch of which, when naked with age, or drled by accident, is the favourite resort of the toucan. It also frequently happens that a wild fig tree, as large as a common English apple tree, rears itself from one of the thick branches of the top of the Mora, and that numerous climbing epiphytes grow upon the fig tree. The fig tree, in time, kills the Mora, and the epiphytes the fig tree. The birds are the agents that convey the seeds to the rotten hollow stump or decaying bark of the Mora and fig." (Waterton's Wanaerings in South America, \&c.) 
to know a newly dead lizard or a snake, from a lizard or a snake basking quite motionless in the sun? If its eye be the director to its food, what blunders must it not make in the negro-yards in Demerara, where broods of ducks and fowls are always to be found the day through, either sleeping or basking in the open air. Still the negro, whom habit has taught to know the Vultur Aura from a hawk, does not consider him an enemy. But let a hawk approach the negro-yard, all will be in commotion, and the yells of the old women will be tremendous. Were you to kill a fowl and place it in the yard with the live ones, it would remain there unnoticed by the vulture as long as it was sweet; but, as soon as it became offensive, you would see the Vultur Aura approach it, and begin to feed upon it, or carry it away, without showing any inclination to molest the other fowls which might be basking in the neighbourhood. When I carried Lord Collingwood's despatches up the Orinoco, to the city of Angustura, I there saw the common vultures of Guiana nearly as tame as turkeys. The Spaniards protected them, and considered them in the light of useful scavengers. Though they were flying about the city in all directions, and at times perching upon the tops of the houses, still many of the people, young and old, took their siesta in the open air, "their custom always of the afternoon," and had no fear of being ripped up and devoured by the surrounding vultures. If the vulture has no extraordinary powers of smelling, which faculty, I am 
told, is now supposed to be exploded since the appearance of the article in Jameson's Journal, I marvel to learn how these birds in Angustura got their information, that the seemingly lifeless bodies of the Spaniards were merely asleep, -

"Dulcis et alta quies, placidæque simillima morti,"

and were by no means proper food for them.

Some years after this, being alongside of a wood, I saw a negro on the ground; and, as I looked at him from a distance, it struck me that all was not right with him. On going up to him I found him apparently dead. Life was barely within him, and that was all. He was a total stranger to me, and I conjectured that he had probably been seized with sickness as he was journeying on, and that he had fallen down there to rise no more. He must have lain in that forlorn, and I hope insensible state, for many hours; because, upon a nearer inspection, I saw swarms of red ants* near lim, and they had eaten deeply into his flesh. I could see no marks that the vultures had been upon him. Indeed, their not being here caused me no surprise, as I had long been satisfied, from the innumerable observations which I had made, that the vulture is attracted to its food

* "The Red Ant of Guiana marches in millions through the country, in compact order, like a regiment of soldiers. They eat up every insect in their march ; and if a house obstruct their rout, they do not turn out of the way, but go quite through it. Though they sting cruelly when molested, the planter is not sorry to see them in his house; for it is but a passing visit, and they destroy every kind of insect vermin that had taken shelter under his roof." (Waterton's Wanderings in South America, \&c.) 
by the putrid exhalations which arise from it, when it has arrived at that state of decomposition which renders it fit, and no doubt delicious, food for this interesting tribe of birds. While I was standing near the negro, I could see here and there a Vultur Aura sweeping majestically through the ethereal expanse, in alternate rises and falls, as these birds are wont to do when in search of carrion; but they showed no inclination to come and perch on the trees, near the prostrate body of this poor unknown sable son of Africa.

The terrible pestilence which visited Malaga at the beginning of the present century, swept off thousands upon thousands in the short space of four months. The victims were buried by the convicts. So great was the daily havoc of death, that no private burials could be allowed; and many a corpse lay exposed in the open air, till the dead carts made their rounds at nightfall to take them away to their last resting place, which was a large pit, prepared for them by the convicts in the daytime. During this long-continued scene of woe and sorrow, which I saw and felt, I could never learn that the vultures preyed upon the dead bodies which had not had time enough to putrefy. But when the wind blew in from the Mediterranean, and washed ashore the corrupted bodies of those who had died of the pestilence, and had been thrown overboard from the shipping, then indeed, "de montibus adsunt Harpyiæ," then it was that the vultures came from the neiglibouring hills to satisfy their hunger; then, one 
might have said of these unfortunate victims of the pestilence,-

"Their limbs, unburied on the naked shore, Devouring dogs and hungry vultures tore."

In Andalusia, one day in particular, I stood to watch the vultures feeding on the putrid remains of a mule, some ten miles from the pleasant village of Alhaurin. Both kids and lambs were reposing and browsing up and down in the neighbourhood, still the vultures touched them not; neither did the goatherds seem to consider their flocks as being in bad or dangerous company, otherwise they might have despatched the vultures with very little trouble, for they were so gorged with carrion that they appeared unwilling to move from the place. Now, seeing some of the kids and lambs lying on the ground quite motionless, and observing that the vultures paid no attention to them, I came to the following conclusion, viz. that the vulture is directed to its food by means of its olfactory nerves coming in contact with tainted effluvium floating in the atmosphere; and this being the case, we may safely infer that the vulture cannot possibly mistake a sleeping animal for one in which life is extinct, and which has begun to putrefy.

If the vulture were directed to its food solely by its eye, there would be a necessity for it to soar to an immense height in the sky; and even then it would be often at a loss to perceive its food on account of intervening objects. But I could never see 
the vulture rise to any very astonishing height in the heavens, as is the custom with the eagle, the glede, and some other birds of prey; and I am even fully of opinion, that when these last-mentioned birds soar so high, they are not upon the look-out for food. When looking at the vultures aloft, I could always distinguish the king of the vultures from the common vulture, and the common vulture from the Vultur Aura. Sometimes an inexperienced observer in Guiana, may mistake for vultures a flock of birds soaring to a prodigious height in the sky; but, upon a steady examination, he will find that they are Nandapoas.

I conceive that we are in error when we suppose that birds of prey rise to such an astonishing lieight as we see them do, in order to have a better opportunity of observing their food on the ground below them. I have watched gledes and hawks intensely, when they have been so high that they appeared a mere speck in the azure vault; still, when at such a great height, I have never been able, in one single instance, to see them descend upon their prey, during the many years in which $I$ have observed them. But, on the other hand, when birds of prey are in quest of food, I have always seen them fly at a very moderate height over the woods and meads, and strike their victim with the rapidity of lightning. Thus, the kestrel hovers at so comparatively short a distance from the earth, that he is enabled to drop down upon a mouse, and secure it as quick as thought. Thus the merlin and sparrowhawk, a little before 
dark, shoot past you when you are watching behind a tree, with inconceivable velocity, and snatch away the unsuspecting bunting from the hedge. But when food seems not to be the object, especially about the breeding season, you may observe the windhovers rising in majestic evolutions to a vast altitude; but, if you watch till your eyes ache, you will never see them descend upon their prey from this immense height: indeed, the great distance to which they rise would operate much against them in their descent to seize their food. For example, suppose a mouse to be on the ground, exactly under a hawk, which hawk is so high up that its appearance to the observer's eye is not larger than that of a lark, how is the hawk to take the mouse? If it descend slowly, the wary mouse would have time to get into its hole ; if the hawk came down rapidly, the noise it causes in darting through the expanse would be a sufficient warning for the mouse to get out of the way. In order to have a proper idea of the noise which the descent of the bird would cause, we have only to listen to a rook in the act of what the peasants call shooting, and which, by the by, they always consider as a sign of coming wind; though, in fact, it can easily be accounted for without any aid from conjecture. It might here be asked, for wliat object, then, do many birds of prey rise to such an amazing height in the sky? I answer, I know not. Why does the lark mount so high, and sing all the time? His female and other listeners on the ground would hear him more distinctly and clearly, were he to 
pour forth his sweet and vernal notes nearer to them.

But to return to the vulture. After the repeated observations I have made in the country where it abounds, I am quite satisfied that it is directed to its food by means of its olfactory nerves coming in contact with putrid effluvium, which rises from corrupted substances through the heavier air. Those are deceived who imagine that this effluvium would always be driven to one quarter in the tropics, where the trade-winds prevail. Often, at the very time that the clouds are driving from the north-east up above, there is a lower current of air coming from the quarter directly opposite. This takes place most frequently during the night-time, in or near the woods; and it often occurs early in the morning, from sunrise till near ten o'clock, when the regular trade-wind begins to blow. Sometimes it is noticed in the evening, after sunset ; and, now and then during the best part of the day, in the rainy season. In Guiana there is a tree called hayawa : it produces a deliciously smelling resin, fit for incense. When the Indians stop on the banks of a river for the night, they are much in the habit of burning this resin for its fine and wholesome scent. It is found in a hardened lumpy state, all down the side of the tree out of which it has oozed. It is also seen on the ground, at the foot of the tree, in. corporated with the sand. When we had taken up our nightly quarters on the bank of the Essequibo, many a time we perceived this delightful fragrance of the hayawa, which came down the bed of the 
river to the place where we were, in a direction quite opposite to the trade-wind. My Indians knew by this that other Indians were encamped for the night on the river-side above us.

When the eruption took place in the Island of St. Vincent, in the Caribbean Sea, in 1812, cinders and other minor particles of matter were carried nearly, if not fully, 200 miles to windward, and were said to have fallen at or near Barbadoes. Had there been a carcass, in a state of decomposition, at the place during the time of the eruption, no doubt the effluvium arising from it would have been taken to windward by a temporary counter-aërial current; and a vulture in Barbadoes might probably have had pretty certain information, through his olfactory nerves, that there was something good for him in the Island of St. Vincent.

Vultures, as far as I have been able to observe, do not keep together in a large flock, when they are soaring up and down apparently in quest of a tainted current. Now, suppose a mule has just expired behind a high wall, under the dense foliage of evergreen tropical trees; fifty vultures, we will say, roost on a tree a mile from this dead mule : when morning comes, off they go in quest of food. Ten fly by mere chance to the wood where the mule lies, and manage to spy it out through the trees; the rest go quite in a different direction. How are the lastmentioned birds to find the mule? Every minute carries them farther from it. Now, reverse the statement; and, instead of a mule newly dead, let us suppose a mule in an offensive state of decomposi- 
tion. I would stake my life upon it, that not only the fifty vultures would be at the carcass next morning, but also that every vulture in the adjacent forest would manage to get there in time to partake of the repast.

Here I will stop, fearing that I have already drawn too largely on the reader's patience; but really I could not bear to see the vulture deprived of the most interesting feature in its physionomy with impunity. These are notable times for ornithology : one author gravely tells us that the water-ousel walks on the bottom of streams; another describes an eagle as lubricating its plumage from an oil-gland; a third renews in print the absurdity that the rook loses the feathers at the base of the bill by seeking in the earth for.its food; while a fourth, lamenting that the old name, Caprimulgus, serves to propagate an absurd vulgar error, gives to the bird the new name of night-swallow.

"In nova fert animus."

THE MEANS BY WHICH THE TURKEY BUZZARD TRACES ITS FOOD.

IN answer to the remark of Mr. Percival Hunter, in the Magazine of Natural History, vol. iv. p. 83., that my account of the habits of the Vultur Aura is at variance with the observations of Wilson, Humboldt, and Azara, I beg to inform him, that I pronounced the Vultur Aura of Guiana to be not gre- 
garious, after the closest attention to its habits, for a long series of years; and I am still of decided opinion that this bird ought not to be considered gregarious.

Wilson was never in Guiana. As for Humboldt, I cannot think of submitting to his testimony, in in matters of ornithology, for one single moment. The avocations of this traveller were of too multiplied a nature to enable him to be a correct practical ornithologist. Azara is totally unknown to me.

I have read Mr. Audubon's paper very attentively, " and upon taking the length, breadth, height, and depth of it, and trying them at home, upon an exact scale," ' $t$ is out, my lord, in every one of its dimensions.

In the paper in Jameson's Journal, after some preliminary observations, the author says, "When I visited the Southern States, and had lived, as it were, amongst these vultures for several years, and discovered, thousands of times, that they did not smell me when I approached them covered by a tree, until within a few feet; and that, when, so near, or at a greater distance, I showed myself to them, they instantly flew away much frightened, the idea evaporated, and I assiduously engaged in a series of experiments to prove, to myself at least, how far the acuteness of smell existed, if it existed at all."

Here the author wishes to prove to us, tlirough the medium of his own immediate person, that the vulture is but poorly off for nose; but he has left the matter short, on two essential points. First, he has told us nothing of the absolute state of his own 
person, at the actual time he approached the vultures; and, secondly, he is silent as to the precise position of his own person, with regard to the wind. This neglect renders his experiment unsatisfactory. If, on his drawing near to the birds, no particular effluvium or strong smell proceeded from his person, it is not to be expected that they could smell him. De nihilo nihilum, in nihilum nil posse reverti, as the old saying is. If, again, he had a smell about him, and he happened to be to leeward as he approached the vultures, their olfactory nerves could not possibly have been roused to action by it, although he had been Gorgonius himself (Gorgonius hircum), for every particle of smell from his person would have been carried down the gale, in a contrary direction to the birds.

I will'now proceed to examine the author's first experiment. "I procured," says he, "a skin of our common deer, entire to the hoofs, and stuffed it carefully with dried grass until filled, rather above the natural size, - suffered the whole to become perfectly dry, and hard as leather, - took it to the middle of a large open field, laid it down on its back, with its legs up and apart, as if the animal was dead and putrid. I then retired about a few hundred yards; and in the lapse of some minutes a vulture, coursing round the field, tolerably high, espied the skin, sailed directly towards it, and alighted within a few yards of it. I ran immediately, covered by a large tree, until within about forty yards; and from that place could spy the bird with ease. He approached the skin, looked at it without apparent suspicion, jumped on it, \&c. - then, approaching 
the eyes, that were here solid globes of hard dried and painted clay, attacked first one and then the other, with, however, no further advantage than that of disarranging them. This part was abandoned; the bird walked to the other extremity of the pretended animal, and there, with much exertion, tore the stitches apart, until much fodder and dry hay was pulled out, but no flesh could the bird find or smell; he was intent on discovering some where none existed; and, after reiterated efforts, all useless, he took flight, coursed about the field, when, suddenly rounding and falling, I saw him kill a small garter snake, and swallow it in an instant. The vulture rose again, sailed about, and passed several times quite low over my stuffed deerskin, as if loth to abandon so good-looking a prey." The author continues : - "Judge of my feelings when I plainly saw that the vulture, which could not discover, through its extraordinary sense of smell, that no flesh, either fresh or putrid, existed about the skin, could, at a glance, see a snake, scarcely as large as a man's finger, alive, and destitute of odour, hundreds of yards distant."

In this first experiment, we are left in such uncertainty, with regard to the actual distance of the vulture from the author, at the time the vulture killed the snake, that I cannot, for the life of me, come to any satisfactory conclusion. It appears, that there was a tree about forty yards from the stuffed deerskin. Under covert of the tree, the author watched the predatory attack of the vulture on the skin. The disappointed bird took flight, and coursed about the field, which the author tells 
us is large and open. While coursing round this field, the vulture, suddenly rounding and falling, killed a garter snake, scarcely as large as a man's finger. The author tells us, he plainly saw that the vulture could see this snake hundreds of yards distant. I am not surprised that the vulture saw the snake hundreds of yards distant, as I am fully aware of the keen sight of all birds; but what really astonishes me is, that the author could see the snake, and know it to be a garter snake; for, upon the face of the statement, I am led to conclude that he himself, as well as the vulture, was hundreds of yards distant from the snake. It were much to be wished that the author had said something positive with regard to the actual distance of the snake from the tree under which he had taken his stand. Again, the author tells us, in the beginning of this experiment, that he retired about a few hundred yards from the spot where he had placed the deerskin, in the middle of the large open field; and that a vulture, in the lapse of some minutes, alighted within a few yards of the skin. The author ran immediately, covered by a large tree, till within about forty yards of the skin. Now, quickness of sight in the vulture being the very essence of our author's paper in Jameson's Journal, I am at a loss to conceive how our author contrived to run over the few hundred yards unseen by the vulture. To be sure, a large tree intervened; but then the vulture happened to be about forty yards on the other side of it; and this distance of the vulture from the tree would be all in its favour for descry- 
ing a man coming up, in an opposite direction, through the open space of a few hundred yards, which, to judge by this vague expression, might be a quarter of a mile, more or less. Had the bird seen him, there is no doubt but that it would have flown away; because the author tells us, in the beginning of his paper, that "when he showed himself to the vultures, they instantly flew away frightened."

"In one part of this experiment, at least, our author proves, beyond the shadow of a doubt, that his vulture was totally deficient in scent; and he has the very best of all reasons, - no smell existed in his deerskin. "No flesh could the bird find, or smell. He was intent on discovering some, where none existed." Still, methinks, the vulture was right in ripping up the pretended animal ; and there was method in his prosecuting his excavation through the regions of dried hay. No lapse of time could have completely subdued the smell which would arise from the ears, the hoofs, the lips, and the very skin itself of the deer. This smell must have been the thing that instigated the bird to look narrowly into the skin, and detained him so long at the place. I have a better opinion of the vulture's sagacity, than to suppose that he would have spent so much of his precious time upon the rudely stuffed mockery of an animal, unless his nose had given him information that some nutriment existed in that which his keen and piercing eye would soon have told him was an absolute cheat. 
- Second Experiment.-The author says, "I had a large dead hog hauled some distance from the house, and put into a ravine, about twenty feet deeper than the surface of the earth around it, narrow and winding, much filled with briars and high cane. In this I made the negroes conceal the hog, by binding cane over it, until I thought it would puzzle either the buzzards, carrion crows, or any other birds to see it, and left it for two days. This was early in the month of July, when in this latitude it becomes putrid and extremely fetid in a short time. I saw, from time to time, many vultures in search of food sail over the field and ravine in all directions, but none discovered the carcass, although during this time several dogs had visited it, and fed plentifully on it. I tried to go near it, but the smell was so insufferable, when within thirty yards, that I abandoned it; and the remains were entirely destroyed at last, through natural decay."

Here the author positively and distinctly tells us, that he saw many vultures, in search of food, sail over the field and ravine, in all directions, but none discovered the carcass; although, during this time, several dogs had visited it, and fed plentifully on it.

Pray, when the dogs were at dinner on the carcass, and the vultures at the same time were flying over the ravine where the hog lay, what prevented these keen-eyed birds from seeing the hog? The author positively says that none discovered the carcass. Could, then, several dogs 
devour the hams of swine, and riot on pig's liver, in such amazing secrecy and silence as not to be observed in the act by the lynx-eyed vultures above? Were there no squabbles amongst the dogs for possession of the pig's cheeks? no snarling for the flitch? no pulling the body this way, or that way? no displacing the materials with which the negroes had covered the hog? In a word, was there no movement on the part of the dogs, by which the passing vultures might receive a hint that there was something in the ravine below "calculated to glut their voracious appetite?" Fear, certainly, could not have kept them away; because the author tells us, in another part of his account, that he has seen vultures feeding at one extremity of a carcass, and dogs at another.

This second experiment, like the story of the "bear and fiddle," was broken off in the middle. The author tried to go near the carcass, but the smell was so insufferable that he abandoned it when he had got within thirty yards of it. He tells us, the remains were entirely destroyed, at last, through natural decay. How did he learn this? At the time that he abandoned the carcass to its fate, the insufferable smell clearly proved that there was plenty of carrion still on the bones; but, as the author's own olfactory nerves prevented him from watching it any longer, I will take upon myself to make up the hiatus valde deflendus, which his sudden retreat occasioned, by a conjecture of my own; namely, that the dogs and vultures, like the devil and the king, in "Sir Balaam," divided the prize. It 
would have taken a lapse of weeks to have destroyed the smell putrescent which came from the remains of so large an animal; and even granted that the vultures had been too dull of nose to have smelled it, still it could not have failed to have attracted other dogs, or the same dogs when their stomachs had become enuty; and they themselves would have gnawed off all the flesh, and squandered the bones, without allowing "natural decay" to consume that which was so palatable to them. Be this as it may, the author immediately returned, and commenced a new operation about the same place. This fortifies me in my conjecture that the carcass must have had some greedy customers after the author's departure, otherwise the insufferable smell must have been still there; and then the author, by his own account, would have been ill able to stand the attack on his nasal feelings during the new operation.

He says, "I then took a young pig, put a knife through its neck, and made it bleed on the earth and grass about the same place, and, having covered it closely with leaves, also watched the result. The vultures saw the fresh blood, alighted about it, followed it down into the ravine, discovered by the blood, the pig, and devoured it when yet quite fresh, within my sight." I must here own I am astonished that the vultures could see this, and still have seen nothing of the large hog while several dogs were feeding on it. However, I request the reader to ruminate for a while on these two experiments with 
the large hog and the little pig; and then he will be able to draw his own conclusion as to the blindness of the vultures during the first experiment, and their keenness of vision during the second.

I will now take a peep at the vultures marshalled in aerial columns.

The author tells us, "a flock of twenty may easily survey an area of two miles, as they go turning in large circles, often intersecting each other in their lines, as if forming a vast chain of rounded links; some are high, whilst others are low; not a spot is passed over unseen; and, consequently, the moment a prey is discovered, the favoured bird rounds to, and, by the impetuosity of its movements, gives notice to its nearest companion, who immediately follows him, and is successively attended by all the rest. Thus the farthest from the discoverer, being at a considerable distance, sails in a direct line towards the spot indicated to him by the flight of the others, who have all gone in a straight course before him, with the appearance of being impelled by this extraordinary power of smelling, so erroneously granted them." Here I break the quotation, to ask the question, how are the hindermost vultures, which are successively attending to the notice given by the favoured bird, in order to profit by it, to know whether the favoured bird has alighted upon some large carrion, or a diminutive garter snake? The leader vulture, according to our author's former experiment, would be equally liable to fall down upon the one as upon the other; and though he might get a mouthful, the rest would be sorely 
disappointed. Again, suppose the leader were to round to and fall upon a stuffed deerskin, and dilly dally his time away in reconnoitring it, would not the rest, on coming up, have just reason to be much out of temper? Our author continues, "If the object discovered is large, lately dead, and covered with a skin too tough to be ate and torn asunder" (cart before the horse), " and afford free scope to their appetite, they remain about it, and in the neighbourhood. Perched on high dead limbs, in such conspicuous positions, they are easily seen by other vultures, who through habit know the meaning of such stoppages, and join the first flock, going also directly, and affording further evidence, to those who are satisfied with appearances only. In this manner I have seen several hundreds of vultures and carrion crows assembled near a dead ox, at the dusk of evening, that had only two or three in the morning; when some of the latter comers had probably travelled hundreds of miles, searching diligently themselves for food, and probably would have had to go much farther had they not espied this association." A little after this, having described the manner in which the "famished cannibals" satisfied their hunger, the author says, "The repast finished, each bird gradually rises to the highest branches of the nearest trees, and remains there, until the digestion of all the food they" (instead of it) "have" (has) "swallowed is completed."

Here we have, perched on high trees, flocks of vultures waiting till their dinner be sufficiently tender; and also flocks of vultures waiting on the D 4 
highest branches of trees till their dinner be sufficiently digested. The author tells us that the first "are easily seen by other vultures, who, through habit, know the meaning of such stoppages." I wish theautlior had told us how he becameinformed of this knowledge, which the " other vultures"' had acquired of these stoppages. Let us suppose for an instant that the latter comers, after travelling "hundreds of miles," had unluckily mistaken the group of vultures perched on high trees; and, in lieu of arriving at the tree under which dinner was waiting for them, they had got to the tree under which all the dinner had been eaten up. Pray, what were the hungry scavengers to do? Were they to proceed, "hundreds of miles" farther, upon an empty stomach, in quest of more stoppages? or were they to wait in patience, with the vultures perched on high dead limbs of trees, till those stomach-filled birds should have digested their food, and were ready to start afresh? The author assures us that "vultures perched on high dead limbs, in sach conspicuous positions, are easily seen by other vultures, who through habit know the meaning of such stoppages :" but then we have only his bare word for this extraordinary circumstance; and, notwithstanding what he has said, my opinion is, that the coming-up vultures would just as often have the bad luck to find themselves arrived at the tree under which the dinner had been all eaten up, as the good luck to get to the tree under which dinner was to be found too tough to be eaten immediately.

Towards the end of the account, our author tells 
us, that " the power given to them (the vultures) by nature of discerning the approaching death of a wounded animal is truly remarkable." By way of exemplification, he continues, " a poor emaciated horse, or $\mathrm{ox}$, the deer mired in the margin of the lake, where the timid animal had resorted to escape flies and musquitoes, so fatiguing in summer, is seen in distress with exultation by the buzzard. He immediately alights, and, if the animal does not extricate itself, waits, and gorges in peace on as much of the flesh as the nature of the spot will allow."

Here the author at once invalidates his assertion of the remarkable power given by nature to the vulture, by the insertion of the unfortunate little remark, if it does not extricate itself. The vulture alights, ready to feed on the flesh of the deer, if it does not extricate itself. Now the expression, if it does not extricate itself, gives us to suppose that it may extricate itself; and, if it does extricate itself, then off it goes, and of course escapes from the vulture. Wherefore, in this instance, nature would have given false information to the vulture.

In closing his account, our author says, "what I have said of their killing and devouring young animals are" (instead of is) "sufficient proofs" (proof) " of this; but it frequently happens that these birds are forced to wait until the hide of their prey will give way to their bills."

In order to substantiate this, our author produces an alligator. " I have seen," says he, " a large dead alligator, surrounded by vultures and carrion crows, of which nearly the whole of the flesh was so com- 
pletely decomposed, before these birds could perforate the tough skin of the monster, that, when at last it took place," (what took place?) " their disappointment was apparent, and the matter, in an almost fluid state, abandoned by the vultures."

Here we have the singular phenomenon of vultures surrounding their own dinner, without being able to touch it, for want, I may say, of suitable carving knives; and at last they are forced to depart on an empty stomach, bearing marks on their countenances of apparent disappointment. I ask, what became of the enormous mass of flesh in the alligator's tail? was it, too, in an almost fluid state, similar to that of the contents of the abdomen? $\mathrm{Had}$, then, the first stage of putrefaction done nothing towards the softening of the skin, which, in the tail of this animal, is by no means so thick as in the dorsal and abdominal regions? Were his vultures so green in the art of perforation as not to have learned that, as soon as putrefaction takes place, the skin of the tail may be easily perforated at the different joints? If the vultures, only for a minute, had but bethouglit themselves of applying their "very powerful bills" to the skin at these joints, it would undoubtedly have yielded to their efforts; and then they could easily have worked their way forward to the other parts of the alligator. Had but our little carrion crow been there, he could soon have taught them how to carve, and shown the lubberly birds where lay the soft parts. Again, I ask, were the vultures, whose daily occupation ought to give them a pretty correct notion of the general 
structure of animals, ignorant that there are certain parts in those animals admirably adapted for contraction and expansion? and, of course, that those parts are invariably softer than the other parts of the bodies of scaly quadrupeds. Did his birds not know, or had they forgot on that occasion, that these parts are to be found, on each side of the alligator, betwixt the nearly impenetrable scaly armour on the back, and the equally impenetrable armour of the under parts? In a word, I am positive, if his vultures had but been well versed in the nature of the parts without, they would soon have introduced themselves to the delicious banquet within, in lieu of surrounding the carcass from day to day, in hope deferred; till at last solids were almost turned into fluids, and the disappointed boobies found themselves under the heart-rending necessity of abandoning the alligator without breaking their fast, and of going in quest of firmer carrion in some other quarter.

If our author's statement be correct, viz. that the skin of a large alligator is too tough to be perforated by the bills of vultures, until time shall have rendered the carcass of the dead animal too fluid to be of any use to them in the way of food; then it follows that no large dead alligator can ever become the food of vultures. The birds may certainly see it at a great distance and wing their way to it, and stop at it; and other vultures, miles behind them, may even fancy " that they know the meaning of such stoppages:" still, I am prone to opine that their labours would be ill requited. In lieu of dropping 
down upon a good dinner, disappointment would be their lot; and they would be regaled with nothing of a more solid nature than transient puffs of highly tainted vapour. But here I will stop: I have been too long on carrion,-

\author{
"Neque enin tolerare vaporem \\ Ulterius potui," \\ Ovid. Met., ii. $s 01$.
}

\title{
THE VULTURE'S NOSE.
}

The American philosophers have signed a solemn certificate that they feel assured that the two species of vultures which inhabit the United States "are guided to their food altogether through their sense of sight, and not that of smell;" I, on the contrary, assert that all vultures can find their food through the medium of their olfactory nerves, though it be imperceptible to their eye.

I cannot consent to deprive the vultures of their noses merely on the strength of experiments which, from circumstances, may prove fallacious, notwithstanding every possible precaution; and, in the cases before us, I find myself constrained to dispute the legitimacy of the deductions at which these gentlemen calculate they have arrived. The effluvium from the dead hare and the offal which they had procured, might have been prevented from ascending by the covering of brushwood; or it might have been depressed to the earth by humidity, or 
by a current of wind. Either of these suggestions may be adopted in the present instance, because the dogs, which had no tainted footsteps to guide them, still found that which insured their discovery of the carrion.

The sad experiment of putting out the poor vulture's eyes fills me with distressing emotions. The supposed fact of the tortured captive not smelling his favourite food, wher placed within an inch of his nostrils, forces us to conclude, either that nature had not intended that his beautifully developed organs of scent should be of the least service to him, or that the intensity of pain totally incapacitated the lone prisoner from touching food. I am of the latter opinion. Unquestionably the pain caused by the dreadful operation rendered the miserable sufferer indifferent to all kind of sustenance. I myself have been unable to eat when in the gripes; and I once knew an old owl which died of sheer want, rather than swallow any thing in captivity. What would the American philosophers think of me, had I got this owl's demise well authenticated by the signatures of divers scientific men, and then despatched it across the Atlantic, in order to prove that owls do not secure their prey by means of their feet, because, forsooth, the incarcerated owl in question never once struck her talons into the food which had been placed within an inch of them.

Nothing can show more forcibly the utter fallacy of the American experiments, than the attack of the vultures on the coarse painting which represented a "sheep skinned and cut up." Till I had read the 
account of it, I had always imagined that the vulture had a remarkably keen and penetrating eye. I must now alter my opinion. If the American gentlemen do not mind what they are about, they will ultimately prove too much (" quod nimitum probat, nihil probat"), and at last compel us Englishmen to conclude that the vultures of the United States can neither see nor smell. They assure us that these birds are not guided to their food by their scent, but by their sight alone; and then, to give us a clear idea how defective that sight is, they show us that their vultures cannot distinguish the coarsely painted carcass of a sheep on canvass from that of a real sheep. They "commenced tugging at the painting," and "seemed much disappointed and surprised" that they had mistaken canvass for mutton. Sad blunder! Pitiable, indeed, is the lot of the American vulture! - His nose is declared useless in procuring food, at the same time that his eyesight is proved to be lamentably defective. Unless something be done for him, $t$ is ten to one but that he'll come to the parish at last, pellis et ossa, a bag of bones.

The American philosophers having fully established the fact, that their vultures are prone to mistake a piece of coarsely painted canvass for the carcass of a real sheep "skinned and cut up," I am now quite prepared to receive accounts from Charleston of vultures attacking every shoulder-ofmutton sign in the streets, or attempting to gobble down the painted sausages over the shop doors, or 
tugging with might and main at the dim and faded eyes in some decaying portrait of the immortal Doctor Franklin.

The absurdity of all this must be evident to every body.

I, in my turn, hope to prove satisfactorily, by inference, that which the American philosophers have failed to demonstrate by EXPERIM ENTs. I state that effluvium from putrid matter, being lighter than common air, necessarily ascends in the atmosphere, unless artificially impeded (as probably was the case in the first experiment of the American philosophers), or prevented from mounting by superincumbent humidity. Now, the organ of scent, which is strongly developed in the vulture, coming in contact with this effluvium, when it is allowed to float in the atmosphere, enables the bird to trace the carrion down to its source. Hence $I$ infer that vultures can find their food through the medium of their olfactory nerves: and, this being the case, I am of opinion that there ought to be no great mystery attached to the act of the vulture's finding putrid bodies, when those bodies are out of sight, either on account of distance, or of interfering objects.

When the American philosophers shall have proved to me, that effluvium from putrid substances does not ascend in the air, and that the organisation of the vulture's nose is imperfect, then I will con. sider myself vanquished; "efficaci do manus scientiæ." After those gentlemen shall have accom- 
plished this, should their vultures pine in famine, by continuing to mistake canvass for carcass, why, rot 'em, they may die, for aught I care to the contrary.

REMARKS ON THE NUDITY ON THE FOREHEAD AND AT THE BASE OF THE BILL OF THE ROOK.

Fœda vit vultus, aut cur hæc nuda patescunt?"

I HAVE more than once nearly made up my mind to sit me down, some dismal winter's evening, and put together a few remarks on the habits of the rook. His regular flight, in congregated numbers, over my house, in the morning to the west, and his return at eve to the east, without the intermission of one single day, from the autumnal to the vernal equinox, would be a novel anecdote in the page of his biography. To this might be added an explanation of the cause of his sudden descent from a vast altitude in the heavens, which takes place with such amazing rapidity that it creates a noise similar to that of a rushing wind. His mischief and his usefulness to mankind might be narrowly looked into, and placed in so clear a light, that nobody could afterwards have a doubt whether this bird ought to be protected as a friend to a cultivated country, or banished from it as a depredating enemy.

I remember, some fifteen years ago, when I was very anxious to divert a footpath which had become 
an intolerable nuisance, the farmers in the district said that I should freely have their good-will to do so, provided I would only destroy a large rookery in a neighbouring wood. On the other hand, the villagers deplored this proposed destruction, as it would deprive them of their annual supply of about two thousand young rooks. Now the gardener abominated them. He called them a devouring set; said that they spoiled all the tops of the trees; and that, for his part, he hoped they would all of them get their necks broken. I myself, for divers reasons, was extremely averse to sign their death-warrant. Were I not fearful of being rebuked by grave and solemn critics, I would here hazard a small quotation :-

"Mulciber in Trojam, pro Troja stabat Apollo; Equa Venus Teucris, Pallas iniqua fuit."

However, at present, it is not my intention to write the life of the rook, or even to inquire incidentally into its vices or its virtues. I merely take up the pen to-day, to show that the nudity on the forehead of the rook, and at the base of both mandibles, cannot be caused by the bird's thrusting its bill into the ground.

Bewick is the only one in Professor Rennie's long and fanciful list of "rudimental naturalists," "literary naturalists," and "philosophic naturalists, and original observers," who gives us any thing satisfactory concerning this nudity. He, sensible naturalist, cuts the knot through at one stroke, by telling us that it is an " original peculiarity." Mon- 
tagu says, that it is acquired by the bird's "habit of thrusting its bill into the ground after worms and various insects." From the study of Professor Rennie, this error is renewed to the public, in the second edition of the Ornithological Dictionary. Let us look into this error.

Every observer of birds must know that when the young rook leaves its nest for good and all, there is no part of its head deficient in feathers. Before winter, this young bird loses the feathers on the forehead, under the bill, and at the base of both mandibles. The skin where these feathors grew puts on a white scurfy appearance. Now, if these feathers have been worn down to the stumps by means of the bird thrusting its bill into the ground, these stumps would fall out at the regular moulting time, and new feathers would soon make their appearance. If, again, these feathers have been loosened at their roots by the process of thrusting the bill into the ground (which I consider next to impossible), and in consequence of this have fallen out from their places, new feathers would be observed in a few weeks; for when once a feather is eradicated, nature instantly sets to work to repair the loss by producing another; nor do we know of any process that can be applied with success, to counteract this admirable provision of nature. Again, these new feathers being full of blood at the roots, any application tending to grind them down, or to eradicate them, would be so painful to the rook, that it would not be able to thrust its bill deep into the ground. 
I request the reader to bear in mind, that these arguments are brought forward only under the accepted supposition of naturalists, that the feathers are removed by the process of the bird thrusting its bill into the ground. But he who examines the subject with attention will at once see that the process itself could not destroy the feathers on the head of the rook; because, if they were destroyed by this process, the carrion crow, the jackdaw, tlie jay, the magpie, and the starling would all exhibit a similar nudity on the forehead, and at the base of the bill; for they all thrust their bills into the ground proportionably as deep as the rooks do theirs, when in quest of worms and grubs. Moreover, if the feathers are eradicated by the act of thrusting the bill into the ground, they would be succeeded by new ones, during the time in which that act could not be put in execution; for example, during a very dry summer, or during a very hard winter; and at these periods, as no action on the part of the rook would operate to destroy the coming feathers, an evident change would soon be observed about the head of the bird. In 1814, the ground was so very hard frozen, and covered with snow for some months, that the rooks could not by any means have an opportunity of thrusting their bills into it. Still, during this protracted period of frost, I could not see a solitary instance of renewal of the feathers on the forehead, or at the base of the bill, in the many birds which I examined.

I deny that the rook does, in general, thrust his 
bill deep into the ground. Look at this bird in the pasture, through a good glass (this puts me in mind of the Professor's suggestion of a thermometer and a stop-watch), and you will see that he merely pulls up the tuft of grass with the point of his bill. When on arable land, he will be observed to thrust his bill comparatively deeper into the mould, to get at the corn, which having just put up its narrow greenish white leaf, the searcher is directed by it to the sprouted grain. But he cannot be at this work above a fortnight: the progress of vegetation then interferes to stop the petty plunderer.

The quao of South America, a bird of the ordier of Pie, has a still greater portion of the forehead bare; and it must have put on this uncouth and naked appearance in early youth, for, on inspecting the head, you will see that feathers have olice been there.

I could never, by any chance, find this bird in the cultivated parts of the country. It inhabits the thick and gloomy forests, and feeds chiefly upon the fruits and seeds which grow upon the stately trees in those never-ending solitudes. In fine, I consider the accepted notion, that the rook loses the feathers of its forehead, and those at the base of each mandible, together with the bristles, by the act of thrusting its bill into the ground, as a pretty little bit of specious theory, fit for the closet; but which, in the field, "shows much amiss."

For my own part I cannot account for the nudity 
in question. He who is clever enough to assign the true cause why the feathers and bristles fall off, will, no doubt, be able to tell us why there is a bare warty spot on each leg of the horse; and why some cows have horns, and some have none. He will possibly show us how it came to happen that the woman mentioned by Dr. Charles Leigh, had horns on her head; which horns she shed, and new ones came in their place. Perhaps he will account for the turkey's putting out a long tuft of hair, amid the surrounding feathers of the breast. Peradventure he may demonstrate to us why the bird camichi, of Guiana, has a long slender horn on its head, and two spurs in each wing, in lieu of having them on its legs. By the way, who knows but that some scientific closet naturalist may account for these alar spurs, of the camichi, through the medium of that very useful and important discovery, the quinary system. Thus, for example's sake, suppose these said spurs were once normal or typical on the legs; but, by some rather obscure process having become aberrant, they made an approach or passage to the wings; while the bird itself was progressing in the circle, or leading round, in order to inosculate with the posteriors of its antecedent. $\mathrm{He}$ who clearly comprehends the quinary system will readily understand this.

If I had time just now, I would call in question the propriety of the assertion that the rook " is furnished with a small pouch at the root of the tongue;' and I would finish by showing the reader that the 
author of the second edition of Montagu was dozing when he deprived the rook (Corvus) of the good old sensible epithet frugilegus, and put that of prædatorius in its place.

ON THE SUPPOSED POUCH UNDER THE BILL OF THE ROOK.

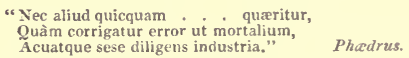

WE read in Rennie's Montagu's Omithological Dictionary, that "the rook is furnished with a small pouch at the root of the tongue." If the carrion crow were as useful to man, as the rook is known to be ; if the jay and the magpie had less to answer for, on the score of petty plunder; and if the jackdaw did not expose itself to persecution, by its prying and suspicious habits, they would all be allowed by man to range at large without molestation; and then the naturalist would have that opportunity of examining their economy, which at present is denied him.

Amongst many peculiarities in these birds, scarcely known, or even noticed, he would observe that at a certain time of the year, and only then, they all have, at intervals, an appearance of 
a pouch under the bill, quite as well defined as that which is seen in the rook. The idea would then occur to him, that ornithologists have either said too much, in stating that the rook is furnished with a small pouch at the root of the tongue; or too little, in not telling us that the carrion crow, the jay, the magpie, and the jackdaw are supplied with a similar convenience.

The real matter of fact is this, that naturalists err when they ascribe a pouch to the rook. Though at times there is an actual appearance of a pouch under the bill of the rook, and also under the bills of the other birds just enumerated, still, upon a close inspection, it will be seen that there is no pouch at all in any of them. The young of all birds, from the size of the thrush to that of the wren, are satisfied with a single worm at one feeding, or with two at the most. Thus, in fields and gardens, we see an old bird catch an insect, and fly away immediately with it to the nest. But food of this scanty measure would not be enough for the larger kind of insectivorous birds. The progeny would undoubtedly require more at each feeding; and, add to this, supposing the bird only carried one insect at each turn, too much time would be lost in passing to and from the nest. To obviate this, as birds of the pie tribe have no power, in health, to eject food which has descended into the stomach (saving the indigestible remnants of aliment, which are thrown up in the form of pellets), they collect a considerable quantity of E 4 
insects into their mouth, and they confine them there, without letting them go down the throat.

By this process, a rook is enabled to pick up a sufficient supply of food, some miles from the nest; and when its mouth will hold no more insects, the bird takes flight, and carries them to its expecting brood. The carrion crow, the jay, the magpie, and the jackdaw do the same thing precisely. Now, the gathered insects, being prevented from descending into the stomach, and at the same time not being able to escape at the bill, must necessarily form a lump under the lower mandible, where the skin, in all birds, is admirably formed for distension. This lump is what has given rise to the notion among naturalists, that the rook is furnished with a pouch at the root of the tongue. If this pouch be allowed in the rook, then it must be admitted that all birds are furnished with a pouch; and it must also be admitted that our tars are furnished with a pouch betwixt the mouth and the ear, because, for convenience sake, they stow away their quid in that quarter.

It may be easily accounted for, why ornithologists make no mention of a pouch under the tongue of the jay, the jackdaw, the magpie, and the carrion crow, while they describe, with such plausibility, a pouch at the root of the tongue of the rook. The reason is this,-the rook, in general, is the friend of man, and, in the breeding season, he becomes so tame that he may be approached within a few yards. This gives you a fine opportunity of observing the 
lump under the bill, when the skin in that part is distended with a supply of food. Indeed, you can observe it at a considerable distance, either while the bird is on the ground, or when it is flying across you, on account of its white appearance, contrasted with the sable plumage. On the other hand, the carrion crow, the magpie, the jay, and even the jackdaw, are all birds of ruined character. Their misfortunes make them shy; and thus you are prevented from having much intercourse with them. The gardener and the henwife can never be brought to look upon them with the least appearance of kind feeling; while the gamekeeper, that cholera morbus to the feathered race, foolishly imagines that he proves his attention to his master's interests, by producing a disgusting exhibition of impaled birds on the kennel walls. Nay, show me, if you can, a young squire, idling from college, who does not try to persuade the keeper that it is his bounden duty to exterminate all manner of owls, ravens, carrion crows, hawks, herons, magpies, jays, daws, woodpeckers, ringdoves, and such like vermin, from his father's estate. With this destroying force to contend with, in the shape of keeper, squire, and henwife, it is not to be wondered at, that naturalists have so few opportunities of watching individuals of the pie tribe through the entire course of their incubation; which individuals, if persecution did not exist, would be seen in the breeding season, perpetually passing to and fro, with their mouths full of food for their young. 
In my little peaceful valley, where the report of the keeper's gun is never heard, and where the birds are safe from the depredations of man, the ornithologist has free access to pursue his favourite study. 'Towards the middle of May, he can see here the carrion crow, the jay, the magpie, and the jackdaw, filling their mouths with grubs and worms, the weight of which forces the pliant skin under the bill into the shape of a little round ball, just of the same appearance as that which is observed in the rook, with this trifling difference, that the lump is feathered in the first, and bare of feathers in the last.

While I am writing this, there may be seen here a wild duck hatching her eggs in a nest upon a sloping wooded bank; while a carrion crow is hatching hers in a fir tree ten yards from the spot, and a windhover hawk is performing the same function in a fir tree about six yards on the other side of the duck. Forty yards from where the carrion crow is hatching, may be seen a barn owl sitting on her eggs in the hollow of an oak tree; and, at twenty yards' distance from the windhover, another white or barn owl has formed her nest in the decayed recesses of a tremendous oak. Though all these families keep the peace, I do not wish it to be understood that they are upon visiting terms. In another part, a long-eared owl is rearing her young in the last year's nest of a carrion crow. When the parent bird is asleep, you can see very distinctly the erect feathers on the head: but the moment she gets a sight of you, down go the erect feathers, and 
lie close to the head; so that an inexperienced observer might take the bird to be a tawny owl. This year, a wild duck has chosen her place of incubation twelve feet from the ground, in an oak tree, near the water; while, in the immediate vicinity, several magpies are hatching in undisturbed repose.

I am sometimes questioned by country gentlemen (who have a keen eye for jugged hare and roasted partridges) on the propriety of befriending, what they consider, feathered vermin. I tell them that Professor Rennie has remarked, in the Magazine of Natural History (vol. v. p. 102.), "that I have hitherto published nothing, respecting the economy or faculties of animals, of the least use to natural history." This being the case, I am trying to make up my deficiency in pen and ink, by establishing a sylvan enclosure, which any ornithologist is allowed to enter; and where he will have an opportunity of correcting, by actual observation, some of those errors which appear in the second edition of Montagu, by James Rennie, A.M. A.L.S. Moreover, sometimes, in a jocose kind of a way, I tell them I like to have all kinds of birds around me; and that I cannot find in my heart to kill a poor jay for sucking an egg, when I know

" That I myself, carnivorous sinner, Had pullets yesterday for dinner." 
ON BIRDS USING OIL FROM GLANDS "FOR THE PURPOSE OF LUBRICATING THE SURFACE OF THEIR PLUMAGE."

" Nardo perunctus,"

Hor. Epod.

Birds, in general, are much troubled with vermin. After applying the solution of corrosive sublimate in alcohol to the fresh skin of a bird, you will see an amazing quantity of insects coming out from all parts of the plumage, but especially from the head. They linger for a few hours on the extremities of the feathers, and then fall off and die : they are of all sizes, from the full-grown insect down to the minutest little creature which has just entered into life and motion. No part of the body of the bird is exempt from their annoyance; and we may judge how much the birds suffer from it, by their perpetual attempts to free themselves from the tormenting attacks of the insects.

People are apt to suppose that a bird is preening, or rectifying, its feathers, when they see it applying its bill to the plumage, and running it down a feather, from the root to the extremity: but a man well versed in the habits of birds knows, when he sees the bird do this (except after it has got wet), that it is trying to dislodge the vermin, which cling with an astonishing pertinacity to the feathers. Now, while the bird is thus employed on that part of its body just above the tail, where there is a gland, some people imagine that the bird is pro- 
curing a liquor from the gland, by means of its beak, in order to apply it to the feathers. But, at best, this can be only mere conjecture on the part of the observer, because the feathers on the rump completely preclude the possibility of his having a distinct view of what the bird is doing.

Will any naturalist declare that he has actually seen a bird procure liquor, or oil, or whatever else you choose to call it, from the gland with its bill, and then apply that liquor or oil to the plumage? The gland has somewhat the appearance of a nipple upon its upper extremity; an oily liquor may be obtained from this nipple by applying our fingers to it; but I marvel how it can be procured by the sharpedged bill of a bird. When the nature of the gland and the form of the bill are duly considered, it is rational to conclude that the application of the hard bill to the soft gland would be very painful to the bird. Let us here suppose that the bird has succeeded in getting some of the liquor into its bill : how is the liquor to be applied to the feathers? It cannot be rubbed upon them, because it is within the bill; and if the bird should apply its bill to the feathers, they would merely come in contact with the edges of the bill, while the liquor would have sunk into the cavity of the lower mandible. Granting that the liquor were removed to the feathers by means of the tongue, then the under part of the feathers would receive more than the upper part. Here let us keep in mind what a large body of feathers there is to be lubricated, and how small the supply of liquor for the purpose of lubrication. 
Moreover, the nipple, in general, is crowned with a circle of feathers; and in all waterfowl which I have examined in the duck tribe, from the swan downwards, the whole of the gland itself is covered with a very thick downy plumage, which would totally prevent the bird from procuring any liquid from that quarter.

I will now show that this oily liquor would injure the feathers. The feathers of birds, when in a perfectly dry state, have a beautiful and downy appearance; in a wet state, the downy appearance is lost, but returns when all the moisture is gone: if, however, any greasy substance or oily liquor has come in contact with them, I do not know what could be employed to restore the downy appearance to its pristine beauty. Let any body apply the oil from the gland in question to a feather, and he will produce a fixed stain.

Suppose, for sake of argument, that the bird does actually employ oil from the gland to lubricate the plumage (which, by the by, I flatly deny), how is the head and part of the neck to be supplied with oil? Why, the truth is, they never can be supplied; and if you examine, with the nicest scrutiny, the feathers of the body which come within the range of the bill, and the feathers of the head, which are out of the range of the bill, and then compare them, you will not observe the smallest difference in their downy appearance: proof positive that the plumage of the body has not been lubricated with oil from the gland.

In the Magazine of Natural History, vol. i. p. 119., 
there is the following account of the lubricating of featliers :-

"The glands containing the oil used for the purpose of lubricating the surface of the plumage were, in the specimen here represented (speaking of the eagle), [" sea-eagle of America, or bird of Washington "], extremely large. The contents had the appearance of hog's fat which had been melted and become rancid. This bird makes more copious use of that substance than the white-headed eagle, or any of the Falco genus, except the fish-hawk; the whole plumage looking, upon close examination, as if it had received a general coating of a thin clear solution of gum arabic, and presenting less of the downy gloss exhibited on the upper part of the bald-beaded eagle's plumage."

Here we have had an abundant flow of oil. If the surface got so much, the under parts of the plumage must have got still more; notwithstanding which, we are told that the glands were extremely large: they ought to have been empty after such a discharge. .Again, if the whole plumage looked " as if it had received a general coating of a thin clear solution of gum arabic," by what process was that general coating applied to the head of the eagle, and to part of the neck, which, we know, cannot possibly be touched by the bill? If it had not been applied to the head and part of the neck, then the bird would have afforded a singular appearance : just as far as the beak could reach, there would have been a distinct coat of what the writer of the article took for oil from the gland; beyond the reach of the beak (that is, on the head, and down part of the neck) there would have been no coating at all.

If that which appeared like a general coating of a thin solution of gum arabic had really been oil from 
the gland, the feathers would have appeared as if they were in a sweat, the oil would have penetrated down their shafts, the fingers of the dissector would have come in contact with grease or oil at every touch, and the whole plumage would have been completely spoiled.

Much safer would it have been for the writer to have had recourse to conjecture, in this affair of a general coating on the whole plumage of the eagle. The bird might have received on its plumage a coat of slime from a fish, struggling and flouncing at its capture, or in the pangs of death; the eagle, after bringing his prey ashore, might have rolled upon it, as we know dogs do upon carrion. In either of these cases there would have been a coating on the plumage, somewhat resembling a solution of gum arabic, while wet; and, when dry, it would have fallen into dust at the touch of the hand; and the feathers would have recovered their downy appearance. In fine, oil or grease on the plumage ought never to have been mixed up in the strange account of the eagle; which would come but poorly off if handled by a severe critic. 
ON THE PRESERVATION OF EGG-SHELLS FOR CABINETS OF NATURAL HISTORY.

"Si sumas ovum, molle sit, atque novum." Schola Salernitana.

I HAVE been blundering at this work for some years ; "seeking for something I could not find," and always dissatisfied with myself on account of the failure. The object of my search was, to try to find out how I could properly dispose of the thin white membrane next the shell of the egg. When left in, it is apt to corrupt; in which case, the colour of the shell will sometimes fade, and an offensive smell is produced, which a lapse of years will not subdue. Last spring I thought I had succeeded; but it turned out to be a very partial success. I, first, by blowing, discharged the contents of five swans' eggs, and then immersed the shells in a tub of water for a month. This enabled me to pull out the thin membrane, by means of a piece of wire bent at the end. But I found that the colour of the shell had faded considerably. Moreover, the process required too much time; and I saw that there would be great difficulty in doing small eggs.

About three weeks ago, a bright thought (a rara avis with me) struck me, just as I was in the act of climbing up to a liawk's nest. I felt certain that every difficulty had vanished, and I began to blame myself on the score of former dulness.

In selecting eggs for your cabinet, always choose those which are newly laid. Make a moderately sized hole at the sharp end, with a pointed instru- 
ment proportioned to the egg. Thus, for a swan's egg, use the point of your penknife; for a robin's, take a small pin. Having made the hole at the sharp end, make one at the blunt end; and let this last hole be as small as possible. This done, apply your mouth to the blunt end, and blow the contents of the egg through the sharpend, where the hole is larger. If the yolk will not come out freely, run a pin or a wire up into the egg, and stir the yolk well about. Now get a cupful of water; and, immersing the sharp end of the shell into it, apply your mouth to the blunt end, and suck up some of the water into the empty shell. Then put your finger and thumb upon the two holes, shake the water well within, and, after this, blow it out. The water will clear your egg of any remains of yolk or of white which might stay in after the blowing. If one sucking up of water will not suffice, make a second or a third.

An egg, immediately after it is produced, is very clean and pure; but by staying in the nest, and by coming in contact with the feet of the bird, it soon assumes a soiled appearance. To remedy this, wash it well in soap and water; and use a nail-brush to get the dirt off. Your egg-shell is now as it ought to be ; and nothing remains to be done but to prevent the thin white membrane (which is still inside) from corrupting.

Take a wine-glass, and fill it with the solution of corrosive sublimate in alcohol. Then immerse the sharp end of the egg-shell into it, keeping your finger and thumb, as you hold it, just clear of the solution. Apply your mouth to the littie hole at the blunt end, and suck up some of the solution into the 
shell. You need not be fearful of getting the liquor into your mouth ; for, as soon as it rises in the shell, the cold will strike your finger and thumb, and then you cease sucking. Shake the shell just as you did when the water was in it, and then blow the solution back into the glass. Your egg-shell is now beyond the reach of corruption; the membrane retains for ever its pristine whiteness; and no insect, for the time to come, will ever venture to prey upon it. If you wish your egg to appear extremely brilliant, give it a coat of mastic varnish, put on very sparingly with a camel-hair pencil. Green or blue eggs must be done with gum arabic, because the mastic varnish is apt to injure the colour.

This is all. How dull I have been, not to have found out this simple process long ago! I have used the solution to preserve skins, furs, and feathers from putrefaction and the moth, for nearly twenty years; still the idea never struck me, till three weeks ago, that it could be so serviceable in preventing all tendency to putrefaction in the membrane of the shell, which had given me so much trouble, and caused so many useless experiments. I trust that the kind-hearted naturalist will not turn this little process of preparing eggs into affliction to poor birds. One egg out of each nest (with a few exceptions) will not be missed by the owner; but to take them all away would be hard indeed. Such an act would make the parent bird as sad and sorrowful as Niobe. You know Niobe's story: Apollo slew her every child.

My friend, George Walker of Killingbeck Lodge, 
thinks that copal varnish is better than mastic varnish for eggs.

I have made an improvement in blowing larger kinds of eggs. I find that one hole is sufficient. When that hole is made, introduce a straight wire, with a little piece of dry cotton or thread tied round the end introduced. Then, holding the egg with the hole downwards, you use the wire, which acts as a piston, and forces a sufficient quantity of the contents of the egg out, to enable you to get out the rest by sudden jerks. This is a much longer process than blowing ; but you have the advantage of having only one hole in your egg, instead of two.

\section{MODE OF BLOWING EGGS.}

When I was at Bridlington last year, in order to acquire some certain knowledge of the water-fowl and their incubation, I made a discovery in the blowing of eggs which I think will please you, and which can be applied with great facility to eggs not smaller than those of the thrush. I made one small hole in the side of the egg, and then sucked out a little of the contents to create a vacuum, or discharged that little by means of a small stick; then, taking the egg in my hand, I plunged my hand in the water to the wrist, and, by shaking the egg while it was immersed in the water, I very soon emptied it of its yolk and white. I have shown this process to many people, and they approve of it highly. 


\section{THE GREEN HUMMING-BIRD.}

\section{" Rursus in arma feror." Virg. Eneid.}

Professor Rennie says, in his "Plan of Study," that "in tropical climates where the heat is great, such domed nests are very common; and are probably intended to protect the mother bird, while hatching, from the intense heat of a perpendicular sun." How well this theory suits the study! how ill it accords with facts in the field of nature! Should the Professor ever go to Guiana, he will see, in the vast wet savannas of that far-extending region, that the little green humming-bird, not much larger than an humble bee, always makes its nest upon the dried twig of a small, straggling, ill-thriving bush. There is not one solitary leaf near the dried twig, to screen the bird from the rising, the noonday, or the setting sun. Nevertheless, this little delicate creature sits on its hemispherical nest, exposed to the downward rays of the fiery luminary, without the least apparent inconvenience. If, then, the tender little green humming-bird can sit all day long exposed to such an intense heat, surely the larger birds, such as the bunya or cassique, surpassing our magpie in size, cannot be supposed to make a dome to their nests, in order to protect their tough and hardy bodies from the rays of a tropical sun. I think this fact of the incubation of the green humming-bird tends to place the Professor's theory of domed nests amongst his "little errors." 


\section{THE VAMPIRE.}

\footnotetext{
"Non missura cutem, nisi plena cruoris hirudo." Hor.

This leech will suck the vein, until

From your heart's blood he gets his fill.
}

THE vampire of India and that of South America I consider distinct species. I have never yet seen a bat from India with a membrane rising perpendicularly from the end of its nose ; nor have I ever been able to learn that bats in India suck animals, though I have questioned many people on this subject. I could only find two species of bats in Guiana with a membrane rising from the nose. Both these kinds suck animals and eat fruit; while those bats without a membrane on the nose seem to live entirely upon fruit and insects, but chiefly insects. A gentleman, by name Walcott, from Barbadoes, lived high up the River Demerara. While I was passing a day or two at his house, the vampires sucked his son (a boy of about ten or eleven years old), some of his fowls, and his jackass. The youth showed me his forehead at daybreak: the wound was still bleeding apace, and I examined it with minute attention. The poor ass was doomed to be a prey to these sanguinary imps of night; he looked like misery steeped in vinegar. I saw, by the numerous sores on his body, and by his apparent debility, that he would soon sink under his afflictions. Mr. Walcott told me that it was with the greatest difficulty he could keep a few fowls, 
on account of the smaller vampire; and that the larger kind were killing his poor ass by inches. It was the only quadruped he had brought up with him into the forest.

Although I was so long in Dutch Guiana, and visited the Orinoco and Cayenne, and ranged through part of the interior of Portuguese Guiana, still I could never find out how the vampires actually draw the blood; and, at this day, I am as ignorant of the real process as though I had never been in the vampire's country. I should not feel so mortified at my total failure in attempting the discovery, had I not made such diligent search after the vampire, and examined its haunts. Europeans may consider as fabulous the stories related of the vampire; but, for my own part, I must believe in its powers of sucking blood from living animals, as I have repeatedly seen both men and beasts which had been sucked, and, moreover, $I$ have examined very minutely their bleeding wounds.

Wishful of having it in my power to say that I had been sucked by the vampire, and not caring for the loss of ten or twelve ounces of blood, I frequently and designedly put myself in the way of trial. But the vampire seemed to take a personal dislike to me; and the provoking brute would refuse to give my claret one solitary trial, though he would tap the more favoured Indian's toe, in a hammock within a few yards of mine. For the space of eleven months, I slept alone in the loft of a woodcutter's abandoned house in the forest; and though the vampire came in and out every night, and I had the finest oppor- 
tunity of seeing him, as the moon shone through apertures where windows had once been, I never could be certain that I saw him make a positive attempt to quench his thirst from my veins, though he often hovered over the hammock.

ON PRESERVING INSECTS SELECTED FOR CABINETS.

I oNLY know of two methods to guard prepared insects from the depredations of living ones. The first is, by poisoning the atmosphere; the second is, by poisoning the preserved specimens themselves, so effectually, that they are no longer food for the depredator. But there are some objections to both these modes. A poisoned atmospliere will evaporate in time, if not attended to, or if neglected to be renewed; and there is great difficulty in poisoning some specimens, on account of their delicacy and minuteness. If you keep spirits of turpentine in the boxes which contain your preserved specimens, I am of opinion that those specimens will be safe as long as the odour of turpentine remains in the box; for it is said to be the most pernicious of all scents to insects. But it requires attention to keep up an atmosphere of spirit of turpentine. If it be allowed to evaporate entirely, then there is a clear and undisputed path open to the inroads of the enemy: he will take advantage of your absence or neglect; and, when you return to view your treasure you will find 
it in ruins. Spirits of turpentine, poured into a common glass inkstand in which there is a piece of sponge, and placed in a corner of your box, will create a poisoned atmosphere, and kill every insect there. The poisoning of your specimens by means of corrosive sublimate in alcohol is a most effectual method. As soon as the operation is properly performed, the depredating insect perceives that the prepared specimen is no longer food for it, and will for ever cease to attack it. But, then, every part must have received the poison; otherwise those parts where the poison has not reached will still be exposed to the enemy; and he will pass unhurt over the poisoned parts, till he arrive at that part of your specimen which is still wholesome food for him. Now, the difficulty lies in applying the solution to very minute specimens, without injuring their appearance; and all that can be said is, to recommend unwearied exertion, which is sure to be attended with great skill ; and great skill will insure surprising success. I myself have attended to the preservation of insects with the assiduity which Horace recommends to poets:- " Nocturnâ versate manu, versate diurnâ." The result has been astonishing success, and a perfect conviction that there is no absolute and lasting safety for prepared specimens, in zoology, from the depredations of insects, except by poisoning every part of them with a solution of corrosive sublimate in alcohol. I put a good large teaspoonful of well pounded corrosive sublimate into a wine bottle full of alcohol. I let it stand over night, and the next morning draw it off into a clean bottle. When 
I apply it to black substances, and perceive that it leaves little white particles on them, I then make it weaker by adding alcohol. A black feather, dipped into the solution, and then dried, will be a very good test of the state of the solution. If it be too strong, it will leave a whiteness upon the feather.

A preparation of arsenic is frequently used; but it is very dangerous, and sometimes attended with lamentable consequences. I knew a naturalist, by name Howe, in Cayenne, in French Guiana, who had lost sixteen of his teeth. He kept them in a box, and showed them to me. On opening the lid _- "These fine teeth," said he, "once belonged to my jaws: they all dropped out by my making use of the savon arsenetique for preserving the skins of animals." I take this opportunity of remarking that it is my firm conviction, that the arsenetical soap can never be used with any success, if you wish to restore the true form and figure to a skin.

I fear that your correspondent may make use of tight boxes and aromatic atmospheres, and still, in the end, not be completely successful in preserving his specimens from the depredation of insects. The tight box and aromatic atmosphere will certainly do a great deal for him; but they are liable to fail, for this obvious reason, viz. that they do not render, for ever, absolutely baneful and abliorrent to the depredator, that which in itself is nutritious and grateful to him. In an evil hour, through neglect in keeping up a poisoned atmosphere, the specimens collected by your correspondent's industry, and prepared by his art, and which ought to live, as it were, for the 
admiration of future ages, may fall a prey to an intruding and almost invisible enemy; so that, unless he apply the solution of corrosive sublimate in alcohol, he is never perfectly safe from a surprise. I have tried a decoction of aloes, wormwood, and walnut leaves, thinking they would be of service, on account of their bitterness: the trial completely failed. Wherefore, in conclusion, I venture to recommend the preserver of insects not to put much trust in simples.

" Contra vim mortis, non est medicamen in hortis."

Against the deadly moth, can I, From herbs, no remedy supply.

It having been stated that the solution I have recommended above, "cannot be applied to the outside of most insects (especially Libellulæ), without, in course of time, injuring their colours," I request attention to the few following observations:- There are two grand distinctions to be made in the colours of insects. Those colours which originate from without, as in the moths and butterflies, remain unimpaired in pristine splendour after death, until they are destroyed by force or by accident. On the other hand, those colours which have their source from within, and proceed from moist substances, gradually fade after the death of the insect; and, in some cases, even totally disappear, when the substances from which they drew their origin have become dry and hard. By long experience, I know that the colours of insects which are produced internally, as in the red dragon fly of 
Guiana, cannot be made permanent, by any process, after the death of the insect; but those colours can be renewed with great and durable effect. Suppose your correspondent were to take an English dragon fly (which, I must inform him, I have never dissected), and sever the head from the thorax, the thorax from the abdomen, and then subdivide the abdomen at every third ring: this would enable him to clear away all the moist internal parts, from whence the colours draw their source. A nearly transparent shell would remain; and he would only have to introduce into it colours similar to those which the insect exhibited in life, after having washed it well with the solution. The joining again of the dissected parts would complete the process. All this appears difficult: still it may be effected. I have read somewhere of a Frenchman who could harness a flea: I, myself, have dissected the Cayenne grasshopper, and renewed its colours with great success. In 1808, after dissecting the bill of the toucan, I completely succeeded in renewing the blue, which had been removed by the knife; and, I believe, the specimen which I produced was the first ever exhibited in its renewed colours since the discovery of America. In the Wanderings, is a full account of this.

With regard to using the spirit of turpentine in preserving insects, I can only say, that I have long and successfully made use of the spirit of turpentine. In 1808, having tried many useless experiments to expel living insects from dead ones, and from other preparations in natural history, on open- 
ing one day an old magazine (I forget now of what denomination) in a planter's house in Essequibo, I read the following remark: - "Spirit of turpentine is known to be the most fatal poison to insects." Taking it for granted that the spirit was fatal through an atmosphere, as I was sure no insect would drink it voluntarily, and I did not see how it could be forced down their throats, I put some spirit of turpentine into a trunk of preserved skins of birds, and into which the moth had found its way. The next morning, I saw that the spirit of turpentine had killed all the moths. In the course of time, the use of the corrosive sublimate in alcohol succeeded to this, and rendered the spirit of turpentine wholly unnecessary, wherever the sublimate could be applied to every part of the preserved specimen. But as on some occasions I only washed the inside of the skins, and, in this case, the feathers themselves, not having received the poison, were still liable to injury from insects, especially in tropical climates, I always took the precaution to have spirit of turpentine in the box. In order to make myself clearly understood, I will describe exactly what I did. I bought common hair trunks which are sent out with goods from Europe to South America; I strewed the bottom of the trunks with cotton, upon which I placed the preserved birdskins, and the different insects which I had collected. Both birds and insects were placed promiscuously in the same trunk. I then saturated a piece of sponge with spirit of turpentine, and hung it up in a corner of the trunk: I renewed this spirit from 
time to time. From that period to this, no living insect lias been detected in the trunks. The plumage of the birds is as vivid as it was at the time I shot them; and the moths and butterflies as splendid as when in life; but most of the other insects, except some of the beetles, have faded. Thus I am enabled to say, by actual experiment, that the atmosphere of spirit of turpentine will allow neither acarus nor any insect to live in it ; and, moreover, that it does not injure the colour of preserved birds, and furs, and insects, provided they do not come in contact with the spirit of turpentine.

I have used corrosive sublimate in paste for years; I have applied the solution to my hat, and to the long Indian arrows (which are very subject to be eaten by the worm), with complete success; and here, in Europe, with equal success, I have applied it to ladies' ostrich feathers, to camel-hair brushes, and to the lining of my carriage. The solution has been the remote cause of my discovering an entirely new method of preserving specimens in natural history; and which method at once shows upon what erroneous principles the old method has been, and is still conducted. To conclude, the solution has proved my best support; without it, I could have done nothing.

"Hoc solamen erat, sylvis hoc victor abibam." 
THE STARLING.

"I CAN'T get out, - I can't get out, said the starling." I know not any thing, except Gay's " Hare and many Friends," that made so much impression on me, when a boy, as Sterne's description of the captive starling in its cage. His attempt to relieve the prisoner bird, - its pressing its breast against the wires, - its teiling every body who came down the passage that it could not get out, its remaining in hopeless captivity, - all tended to make this pretty bird particularly interesting to me; and, in days long past, I have spent many an hour in listening to its morning warblings, and in admiring its aerial evolutions towards the close of day.

I wish I could do it a friendly turn, for the pleasure it has so often afforded me; but, in taking up the pen to clear its character, my heart misgives me, on account of the strong public prejudice against it.

There is not a bird in all Great Britain more harmless than the starling: still it has to suffer persecution, and is too often doomed to see its numbers thinned by the hand of wantonness or error. The farmer complains that it sucks his pigeons' eggs ; and, when the gunner and his assembled party wish to try their new percussion locks, the keeper is ordered to close the holes of entrance into the dovecot overnight; and the next morning three or four dozen of starlings are captured to be shot: while 
the keeper, that slave of Nimrod, receives thanks, and often a boon, from the surrounding sportsmen, for having freed the dovecot from such a pest. Alas ! these poor starlings had merely resorted to it for shelter and protection, and were in no way responsible for the fragments of egg-shells which were strewed upon the floor. These fragments were the work of deep-designing knaves, and not of the harmless starling.

The rat and the weasel were the real destroyers; but they had done the deed of mischief in the dark, unseen and unsuspected; while the stranger starlings were taken, condemned, and executed, for having been found in a place built for other tenants of a more profitable description.

After the closest examination of the form and economy of the starling, you will be at a loss to produce any proof of its being an egg-sucker. If it really sucks the eggs of pigeons, it would equally suck the eggs of other birds; and, those eggs not being concealed in the dark recesses of the pigeoncot, but exposed in open nests on the ground, and often in the leafless bushes of the edge, this fact would afford to the inquisitive naturalist innumerable opportunities of detecting the bird in its depredations. Now, who has ever seen the starling in the absolute act of plundering a nest? It builds its nest here, in company with the ringdove, the robin, the greenfinch, the wagtail, the jackdaw, the chaffinch, and the owl, but it never touches their eggs. Indeed, if it were in the habit of annoying its immediate neighbours, upon so tender a point as 
that of sucking their eggs, there would soon be hue and cry against it; nor would the uproar cease until the victor had driven away the vanquished. So certain am I that the starling never sucks the eggs of other birds, that, when I see him approach the dovecot, I often say to him, "Go in, poor bird, and take thy rest in peace. Not a servant of mine shall surprise thee, or hurt a feather of thy head. Thou dost not come for eggs, but for protection; and this most freely I will give to thee. I will be thy friend in spite of all the world has said against thee; and here, at least, thou shalt find a place of safety for thyself and little ones. Thy innocence and usefulness demand this at my hands."

The starling is gregarious; and I am satisfied in my own mind that the congregated masses of this bird are only dissolved at the vernal equinox, because they have not sufficient opportunities afforded them of places wherein to build their nests. If those opportunities were offered them, we should see them breeding here in multitudes as numerous as the rook. They require a place for their nest, well protected from the external air. The inside of the roof of a house, a deep hole in a tower, or in the decayed trunk or branch of a tree, are places admirably adapted for the incubation of the starling; and he will always resort to them, provided he be unmolested. The same may be said of the jackdaw.

Attentive observation led me to believe that the great bulk of starlings left our neighbourhood in the spring, solely for want of proper accommodation for their nests. For many years, two pairs of starlings 
only remained on my island. One of them regularly built its nest in the roof of the house, having found entrance through a neglected aperture; the other reared its young, high up, in the deep hole of an aged sycamore tree. Two or three pairs frequented the dovecot; but I observed that they built their nests in the crannies, and not in the holes made for the pigeons. These poor birds, together with the owl, had to suffer persecution from wanton ignorant servants, until I proclaimed perpetual peace in their favour, and ordered, I may say, the Temple of Janus to be shut, never more to be opened during my time.

Having been successful in establishing the owl in the old ivy tower over the gateway, I conjectured, from what I had observed of the habits of the starling, that I could be equally successful in persuading a greater number of these pretty lively birds to pass the summer with me. I made twentyfour holes in the old ruin; and in the spring of this year I had twenty-four starlings' nests. There seemed to be a good deal of squabbling about the possession of the holes; till, at last, might overcame right. The congregated numbers suddenly disappeared, no doubt with the intention of finding breeding quarters elsewhere; and the remaining four and twenty pairs hatched and reared their young; causing, I fear, the barn owls, their nextdoor neighbours in the tower, many a sleepless day, by their unwelcome and incessant chatterings.

On the one hand, when we consider how careful the starling is in selecting a place for its incubation, 
sheltered from the storm; and, on the other, when we look around us, and see how many old houses have been pulled down, where these birds found a refuge; and when we reflect how modern luxury, and the still more baneful turf, have forced many a country squire to fell his aged oaks, his ash trees, and his sycamores, which afforded the starling a retreat; it will not require the eyes of Argus to enable naturalists to discern the true cause why such numbers of assembled starlings take their leave of us in early spring.

This year, seven pairs of jackdaws, twenty-four pairs of starlings, four pairs of ringdoves, the barn owl, the blackbird, the robin, the redstart, the house sparrow, and chaffinch, have had their nests in the old ivy tower. The barn owl has had two broods; and, while I am writing this, there are halffledged young ones in the nest. As far as I can learn, there has been no plunderings of the eggs of this community, on the part of the starlings.

Now that autumn has set in, the movements of this delightful assemblage of birds already warn us to prepare for winter's chilling blasts. The redstart is gone to Africa: the chaffinch has retired to the hawthorn hedges: the ringdoves, having lost half of their notes by the first week in October, became mute about ten days ago; and have left the ivy tower, to join their congregated associates, which now cliefly feed in the turnip fields; and will re. turn no more to the ivy tower until the middle of February. The jackdaws are here, morning and evening, and often at noon; and at nightfall they 
never fail to join the passing flocks of rooks in their evening flight to their eastern roosting-place at Nostell Priory, and return with them after daybreak. The starlings retire to a dense plantation of spruce fir and beech trees, and in the morning come to the ivy tower to warble their wild notes, even when the frosts set in. These birds are now in their winter garb, which they assumed at the autumnal equinox, much duller, and of a more greyish white appearance, than that which they had in the summer. I cannot find that naturalists have noticed this change.

The starling seems to be well aware of the peaceful and inoffensive manners of the windhover. This hawk rcars its young in a crow's old nest, within two hundred yards of the ivy tower. Still, the starlings betray no fears when the windhover passes to and fro; but they become terribly agitated on the approach of the sparrowhawk. I often see this bold destroyer glide in lowly flight across the lake, and strike a starling and carry it off, amid the shrieks and uproar of the inhabitants of the tower and sycamore trees.

The starling shall always have a friend in me. I admire it for its fine shape and lovely plumage; I protect it for its wild and varied song; and I defend it for its innocence. 
PRESERVING THE COLOUR OF THE LEGS AND BILLS OF STUFFED BIRDS.

I coxsIDER it impossible to preserve the colours unimpaired in the legs of stuffed birds. I have. seen the lake-coloured leg of the beautiful yawarraciri of Guiana lose every particle of the red; and I have found that no external application can preserve the fine colours in the legs of the scarlet curlew, the trunpeter, the water-hen of Guiana, and many other birds too numerous to mention.

Under the outward scale of the leg, in the living bird, are substances from which the leg derives its colour. They fade in time after the death of the bird, and then the whole complexion of the leg is changed. Perhaps you might partially succeed in renewing the faded colours of the leg, by means of paint mixed up with water: at best it is a bad business. The legs of birds stuffed on the old system are so shrunk and hideous to the eye, that, in my opinion, their colour is a mere secondary consideration. In the bills of birds, the colours are either produced from internal substances, as in the base of the lower mandible of the toucan; or inherent in the horn or bone itself, as in the cassique. In either case, dissection is absolutely necessary, if you wish to have the beauty of the bill retained or renewed. 


\section{THE HABITS OF THE CARRION CROW.}

"Inter aves albas, vetuit consistere corvum."

Ovid. Met.

The crow was order'd not to hold a place

'Mid whiter favourites of the feather'd race.

This warrior bird is always held up to public execration. The very word carrion, attached to his name, carries something disgusting with it; and no one evcr shows him any kindness. Though he certainly has his vices, still he luas his virtues too; and it would be a pity if the general odium in which he is held should be the means, one day or other, of blotting out his name from the page of our British ornithology. With great propriety he might be styled the lesser raven in our catalogue of native birds; for, to all appearance, he is a raven; and I should wish to see his name changed, were I not devoutly attached to the nomenclature established by the wisdom of our ancestors.

The carrion crow is a very early riser; and, long before the rook is on the wing, your hear this bird announcing the approach of morn, with his loud hollow croaking, from the oak to which he had resorted the night before. He retires to rest later than tlie rook: indeed, as far as I liave been able to observe his motions, I consider him the first bird on wing in the morning, and the last at night, of all our non-migrating diurnal British birds.

When the genial voice of spring calls upon him to prepare for the continuation of his species, the carrion crow, which, up to this period, has been 
wary, shy, and cautious, now, all of a sudden, seems to lose these qualities; and, regardless of personal danger, sometimes makes his nest within a lıundred yards of the habitation of man, upon a tree, at once the most conspicuous and exposed. To us, who know so little of the economy of birds, this seems a strange phenomenon; nor can any penetration of which we may be possessed enable us to comprehend the true meaning of this change from timidity to boldness, from distance to proximity, from wariness to heedlessness, in so many different species of birds. One would suppose that they would be more shy and distant at this interesting period; and, in imitation of the cat, the rabbit, and the fox, conceal as mucl as possible the place of their retirement. The rook will sometimes build a poor and slovenly nest, but this is never the case with the carrion crow; this bird invariably makes its nest firm and compact. A writer, who signs himself A. B. C., in the Magazine of Natural History (vol. i. p. 590.), tells us that "some of the nests have such deep beds of wool, moss, and cows' hair, that the eggs seemed quite lost; and might have given the professor his erroneous idea of their being covered with those substances to keep them warm." $O$, fie! How is it possible that the eggs should seem quite lost, when the lining on which they lie is so perfectly smooth that they appear as though they were in a basin. Not a single particle of the lining of the nest is ever seen betwixt the eggs and the eye of him who has ascended the tree to take a view of them. I challenge any naturalist to bring proof G 4 
positive which can invalidate this assertion. Verily when the Professor climbs up to crows' nests this ensuing spring, he will agree with Ovid, that "Causa patrocinio, non bona, pejor erit."

The carrion crow never covers its eggs on leaving the nest; they are generally from three to five, and sometimes even six, in number; wonderfully irregular in size and shape and colour. This irregularity is so very apparent, that on examining the nests of some carrion crows with eggs in them, you might fancy to yourself that the rook had been there, to add one of hers to those already laid by the original owner.

This bird never builds its nest in hedges, but will construct it in any of our forest trees; and, with me, it seems to give the preference, in general, to the cak, the spruce fir, and the Scotch pine. The young are hatched naked and blind, and remain blind for some days.

Our ancestors, no doubt, bestowed the epithet "carrion" upon this bird, in order to make a clear and decided distinction between it (whose flesh, they prob:ibly supposed, was rank and bad) and the rook, the flesh of which was well known to be good and wholesome food. Perhaps, too, in those days of plenty, and of less trade, the carrion crow had more opportunities of tasting flesh than it has in these our enviable times of divers kinds of improvement. Were a carrion crow of the present day to depend upon the finding of a dead cow or horse for its dinner, would soon become an adept in the art of fasting by actual experiment; for, no sooner is one of these animals, in our neighbourhood, struck by the hand 
of death, than its hide is sent to the tan-pit, and its remains are either made into soup for the hunt, or carefully buried in the dunghill, to increase the farmer's tillage. The poor crow, in the mean time, despised and persecuted for having an inclination to feed upon that of which, by the by, the occupier of the soil takes good care that he shall scarcely have a transient view, is obliged to look out for other kinds of food. Hence you see it regularly examining the meadows, the pastures, and the corn fields, with an assiduity nor even surpassed by that of the rook itself.

We labour under a mistake in supposing that the flesh of the young carrion crow is rank and unpalatable. It is fully as good as that of the rook; and I believe that nobody who is accustomed to eat rook-pie will deny that rook-pie is nearly, if not quite, as good as pigeon-pie. Having fully satisfied myself of the delicacy of the flesh of young carrion crows, I once caused a pie of these birds to be served up to two convalescent friends. whose stomach would have yearned spasmodically had they known the nature of the dish. I had the satisfaction of seeing them make a hearty meal upon what they considered pigeon-pie.

The carrion crow will feed voraciously on ripe cherries; and, in the autumn, he will be seen in the walnut trees, carrying off, from time to time, a few of the nuts. With the exception of these two petty acts of depredation, he does very little injury to man during nine or ten months of the year; and if, in this period, he is to be called over the coals for occasionally throttling an unprotected leveret or a stray partridge, he may fairly meet the accusation 
by a set-off against it in his account of millions of noxious insects destroyed by him. However, in the spring of the year, when he has a nest full of young to provide for, and when those young begin to give him broad hints that their stomachs would like something of a more solid and substantial nature than mere worms and caterpillars, his attention to game and poultry is enough to alarm the stoutest-hearted squire and henwife. These personages have long sworn an eternal enmity to him; and he now, in his turn, visits, to their sorrow, the rising hopes of the manor with ominous aspect; and he assaults the broods of the duck-pond, in revenge, as it were, for the many attempts which both squire and henwife have made to rob and strangle him.

In 1815, I fully satisfied myself of his inordinate partiality for young aquatic poultry. The cook had in her custody a brood of ten ducklings, which had been hatched about a fortnight. Unobserved by any body, I put the old duck and her young ones in a pond, nearly three hundred yards from a high fir tree in which a carrion crow had built its nest: it contained five young ones almost fledged. I took my station on the bridge, about one hundred yards from the tree. Nine times the parent crows flew to the pond, and brought back a duckling each time to their young. I saved a tenth victim by timely interference. When a young brood is attacked by an enemy, the old duck does nothing to defend it. In lieu of putting herself betwixt it and danger, as the dunghill fowl would do, she opens her mouth, and shoots obliquely through the water, beating it with 
her wings. During these useless movements, the invader secures his prey with impunity.

I would reconmend all henwives, in early spring, to place their ducks' eggs under a hen. At that time of the year there are no weeds on ponds sufficiently high to afford slielter to the young, when they are led on to the water by their real mother. If the first sitting of eggs be taken from a duck, she will generally lay a second time; and that will be at a period when the water abounds with weeds, amongst which the young brood can skulk, and screen itself from the watchful eye of an enemy.

From what I have written, the reader may be able to form a pretty correct idea of the habits of the carrion crow ; and he will perceive that, for nearly ten months of the year, this bird, far from being considered an enemy, ought to be pronounced the friend of man.

Let us now examine if the attacks of this hird on domestic poultry cannot be easily counteracted; and whether its assiduous attention to the nests of pheasants and of partridges is of so alarming and so important a nature as to call for itsutter externination from the land. For my own part, I acknowledge that I should lament his final absence from our neadows and our woods. His loud and varied notes at early dawn, and again at latest eve, are extremely grateful to me; and many an hour of delight do I experience, when, having mounted up to the top of a favourite aged oak which grows on the border of a swamp, I see him chasing the heron and the windhover through the liquid void, till they are lost in 
the distance. Then, again, how eager is his pursuit ! - how loud his croaking! - how inveterate his hostility!-when he has espied a fox stealing away from the hounds, under the covert of some friendly hedge. His compact and well-built figure, too, and the fine jet black of his plumage, are, in my eye, beautifully ornamental to the surrounding sylvan scenery.

A very small share of precaution, on the part of the henwife, would effectually preserve her chickens and her ducklings from the dreaded grasp of the carrion crow. Let her but attend to the suggestion of setting her early ducks' eggs under a hen, and let her keep that hen from rambling, and she will find her best hopes realised. As for the game, I verily believe that, in most cases, the main cause of the destruction of its eggs may be brought home to the gamekeeper himself. This unrelenting butcher of our finest and rarest British birds goes, forsooth, and makes a boast to his master that he has a matter of five hen pheasants hatching in such a wood, and as many partridges in the adjacent meadows. This man probably never reflects that, in his rambles to find the nests of these birds, he has made a track, which will often be followed up by the cat, the fox, and the weasel, to the dircful cost of the sitting birds; and, moreover, that by his own obtrusive and unexpected presence in a place which ought to be free from every kind of inspection, whether of man or beast, he has driven the bird precipitately from her nest, by which means the eggs 
are left uncovered. Now, the carrion crow, sweeping up and down in quest of food, takes advantage of this forced absence of the bird from her uncovered eggs, and pounces down upon them. He carries them off, not in his bill, but on the point of it, having thrust his upper mandible through the shell. Had there been no officious prying on the part of the keeper, it is very probable that the game would have hatched its brood in safety, even in the immediate vicinity of the carrion crow's nest ; for instinct. never fails to teach the sitting bird what to do. Thus, in the wild state, when wearied nature calls for relaxation, the pheasant first covers her eggs, and then takes wing directly, without running from the nest. I once witnessed this, and concluded that it was a general thing. From my sitting-room, in the attic story of the house, I saw a pheasant fly from her nest in the grass; and, on her return, she kept on wing till she dropped down upon it. By this instinctive precaution of rising immediately from the nest on the bird's departure, and its dropping on it at its return, there is neither scent produced, not track made, in the immediate neighbourhood, by which an enemy might have a clew to find it out, and rob it of its treasure. These little wiles are the very safety of the nest; and I suspect that they are put in practice by most birds which have their nest on the ground. To these wiles, in part (before gangs of forty or fifty nocturnal poachers desolated this district), I attributed the great increase of $\mathrm{my}$ pheasants, though they were surrounded by liawks, 
jays, crows, and magpies, which had all large families to maintain and bring up in the immediate neiglıbourhood.

Keepers may boast of their prowess in setting traps (and, in testimony of their success, they may nail up the mutilated bodies of carrion crows against the kennel wall); but I am of opinion, that, if the squire could ever get to know the real number of pheasants and hares, which have been killed or mutilated in those traps, he would soon perceive that he had been duped by the gamekeeper; and that henceforth he would forbid him to enter the covers in the breeding season, for the purpose of destroying the carrion crows. The frequent discharge, too, of the keeper's gun, though it may now and then kill or wound a carrion crow, still will infallibly drive away the game in the end, and oblige it to seek some more favoured and sequestered spot. As to the setting of poison, - a practice so common with these worthless destroyers of crows, hawks, rnagpies, jays, and ravens, which they are pleased to style feathered vermin, it is a well known fact that foxes, ducks, dogs, hogs, and pheasants are all liable to fall a prey to the noxious bait. Often has the disappointed vulpine sportsman to mark down a blank day in his calendar, on account of his quarry having supped upon what was laid to kill the carrion crow ; and I have reason to believe that the fox sometimes loses his life, by feeding on carrion crows which have died by poison.

If we were to sum up, on one side, the probable number of pheasants and partridges destroyed during one season by the carrion crow; and, on the other, 
reckon up how many times the keeper has disturbed the game by going in search of this bird, and thus exposed the nests of partridges and pheasants to certain destruction by vermin of all kinds; and then, if we take into the account the many heads of game which the keeper has killed in his steel traps and rabbit-snares, we should conclude, I think, that, in the long run, the game actually suffers more from the keeper, in his attempts to destroy the crow, than it really does from the crow itself, while catering for its young. Indeed, I have made out the account myself; and, finding the balance to be against the keeper, I have renewed the order which I gave to his predecessor, never, upon any score, to persecute what is commonly called flying vermin. Thus, the partridges and pheasants here, during the time of incubation, are abandoned to their own discretion: and I judge, from what I liave seen, that old Dame Nature, without any interference on my part, will kindly continue to point out to these birds proper places where to lay their eggs and rear their young; and, moreover, I am conficlent she will teach them, by her own admirable and secret process, how to elude the prying scrutiny of the carrion crow. Should, however, the country squire, whose eye is seldom quite closed to the advantages derived from a well-stored autumnal larder; should he, I say, not have sufficient faith in the dame's protecting care, it will be some consolation to him to be informed that, when birds of the game species lose their first eggs, they seldom fail to have a second hatch, which will be sure to find ample security from its enemies, 
in the abundant growth of summer grass and corn.

The carrion crow is evidently gregarious at times, in the autumnal and winter months: I have sometimes counted fifty of them together. Unlike the rook, these birds never become bare of feathers at the base of the bill.

The vulgar remark, that a carrion crow can smell gunpowder, ought to be received with explanation. The natural wariness of this bird at most seasons of the year, and the perpetual persecution it has to undergo from man, are the causes of its keeping a very sharp look-out; and it takes flight at the earliest approach of the gunner; hence the surmise that it smells the powder (which might certainly be smelled after the discharge of the gun, provided the crow were to leeward); but then the loud report would cause it to take instant flight, and it would be far away long before the scent from the burnt gunpowder could have any chance of reaching its olfactory nerves, though they were (and, for aught I know, they are) as sensible as those of the vulture.

I turn loose on the public, from my park, about threescore carrion crows per annum; which no, doubt, are considered as a dangerous lot of rascals by the good folks of this neighbourbood.

I beg to say that I have written this paper ex. pressly to calm the fears of sportsmen, who may imagine that $I$ do an evil deed in befriending a tribe of birds hitherto considered, by common consent, in no other light than that of plundering rogues and vagabonds. If they will do me the honour to 
read this little history of my warrior bird, I trust they will be satisfied that he is not such a desperate thief as he is generally imagined to be; and, furthermore, upon due consideration, they will agree with me that, when the keeper is abroad with his gun, his poison, and his traps, their game may be said, with great truth, to be exposed to much worse company than that of the carrion crow.

\section{HABITS OF THE PHEASANT.}

THIs splendid well-known inhabitant of our woods and plains is generally supposed to have come from Asia, though the time of its arrival in this cold and cloudy climate seems to be quite unknown.

A variety of this bird, sometimes spotted and sometimes milk-white, appears among the other pheasants, and breeds with them. I have never yet been able to perceive that it continues its white or varied plumage to the offspring. The plumage of the white or pied pheasant seems purely accidental, and is produced by a male and female of ordinary colours. The ring-neck pheasant, so common in the more northern parts of the kingdom, is never seen in this immediate neighbourhood.

By the laws of England, the pheasant is considered game; and the sportsman is under the necessity of taking out a licence from government, in order to qualify himself to shoot it. When we consider the 
habits of this bird, we are apt to doubt of the propriety of placing it under the denomination of fere natura ; and $I$ am one of those who think that it would be a better plan to put it on the same footing with the barn-door fowl, by making it private property ; that is, by considering it the property of the person in whose field or wood it may be found. The pheasant is a more than half-reclaimed bird. While the hare and the partridge wander in wildest freedom through the land, hecdless of the fostering care of man; the bird in question will come to us, at all hours of the day, to be fed. It will even sometimes associate with the poultry on the farm; and, where it is not disturbed, it will roost in trees, close to our habitations.

Its produce with the barn-door fowl is unprolific, and seems to have nothing to recommend it to our notice on the score of brilliancy of plumage, or of fineness of shape.

The pheasant crows at all seasons, on retiring to roost. It repeats the call, often during the night, and again at early dawn; and frequently in the daytime, on the appearance of an enemy, or at the report of a gun, or during a thunder storm. I am of opinion that it does not pair. The female lays from seven to eighteen eggs; but in general the nest contains about twelve.

Notwithstanding the proximity of the pheasant to the nature of the barn-door fowl, still it has that within it which baffles every attempt on our part to render its domestication complete. What I allude to is, a most singular innate timidity, which never 
fails to show itself on the sudden and abrupt appearance of an object. I spent some months in trying to overcome this timorous propensity in the pheasant; but I failed completely in the attempt. The young birds, which had been hatched under a domestic hen, soon became very tame, and would even receive food from the hand, when it was offered cautiously to them. They would fly up to the window, and would feed in company with the common poultry. But, if any body approached them unawares, off they went to the nearest cover with surprising velocity. They remained in it till all was quiet, and then returned with their usual confidence. Two of them lost their lives in the water by the unexpected appearance of a pointer, while the barn-door fowls seemed scarcely to notice the presence of the intruder. The rest took finally to the woods at the commencement of the breeding season. This particular kind of timidity, which does not appear in our domestic fowls, seems to me to oppose the only, though at the same time an insurmountable, bar to our final triumph over the pheasant. After attentive observation, I can perceive nothing else in the habits of the bird, to serve as a clue by which we may be enabled to trace the cause of failure in the many attempts which have been made to invite it to breed in our yards, and retire to rest with the barn-door fowl and turkey.

Though a preserve of pheasants is an unpopular thing, still I am satisfied in my own mind that the bird cannot exist in this country without one; at the same time, I am aware that a preserve may be 
overdone. Thus, when pheasants are reserved for a day of slaughter, under the appellation of a battu, the regular supply of the market is endangered, the diversion has the appearance of cruelty, and no good end seems to be answered. It exposes the preservers of pheasants in general to the animadversions of an angry press, which are greedily read, and long remembered, by those whose situation in life precludes them from joining in the supposed diversion. However ardently I may wish to protect the pheasant in an ornithological point of view, - I say ornithological, for its flesh I heed not, - still, I am fully aware, that the danger to be incurred and the odium to be borne are mighty objections. We read, that the ancients sacrificed a cock to Æsculapius: perhaps the day is at no great distance, when it will be considered an indispensable act of prudence for the country gentleman to offer up his last hecatomb of pheasants at the shrine of public opinion.

The more we look into the habits of the pheasant, the more we must be persuaded that much greater attention ought to be paid to it than is generally paid to other kinds of game. The never-failing morning and evening notice which it gives of its place of retreat, together with its superior size, cause it to be soon detected and easily killed. The tax, too, which government has put upon it, enliances its value as an indispensable delicacy at the tables of those who give good cheer. In fact, few are the autumnal and winter dinners of the wealthy, where a roasted pheasant does not grace the second course. The 
fowling-piece of the nocturnal poacher is the most fatal weapon used for its destruction. The report of a gun or a clap of thunder, during the night, will often cause the pheasants to begin to crow, as I have already stated; and this greatly endangers their safety. When once they are frightened from their roost, they never perch again during the remainder of the night, but take refuge among the grass and underneath the hedges, where they fall an easy prey to the cat, the fox, and the stoat. A poacher armed with a gun finds a cloudy night fully as good for slaughter as one in which the moon shines; and, if larch trees grow in the wood, to these he resorts; knowing, by experience, that the pheasant prefers this kind of tree to any other. The larch suits pheasants admirably, on account of its branches growing nearly at right angles from the stem. This renders the sitting position of the birds very easy. I consider the smoking of pheasants, while they are roosting in the tree, as a mere idle story. I myself ought to be a pretty good hand at poaching ; still, I am obliged to confess that I have never been successful, in one single instance, in the many attempts I have made to bring down the pleasant from his roost by the application of a smoking apparatus. Indeed, when we reflect that the mouth of the bird is always shut during sleep, and that both it and the nostrils are buried in the dorsal feathers, we are at a loss to conceive how the smoke can enter them, and cause the bird to fall in stupefaction. If smoking were a successful method, depend upon it the poachers would never be such noodles as to use 
a gun; the report of which is sure to bring an attentive keeper to the scene of their niglit's diversion.

To the illegal possession of the pleasant, alone, may be traced the cause of all the sanguinary nocturnal conflicts between the poachers and those who are appointed to watch for its safety. The poacher is well aware that he cannot procure pheasants without the aid of a gun; and he knows, at the same time, that the report of that gun will betray him, and bring up the watchers, against whom he would have no chance, single-handed. Wherefore, in order that he may come off victorious, he musters an overwhelming force of tinkers, cobblers, masons, smiths, and labourers, armed with bludgeons, and, perhaps, here and there a rusty gun. Taking the precaution to get well primed with beer, off they go, fully bent on having every thing their own way. The pheasants fall; the watchers come up; oaths and curses are poured out, and a desperate fray commences. Here are furnished, work important for the nearest magistrate, profit to his clerk, expense to the county, and practice for Mr. Ketch. Let it be also observed, that the unlawful capture of the hare and the partridge (which are really ferce naturâ) does not produce similar work of mischief. These are taken with nets and snares. The fewer poachers employed, the more certain is their success. A number of men would only do harm, and mar the plan of capture. So silently is this mode of poaching carried on, that the owner of the soil is not aware of the loss he is about to 
sustain in the plunder of his game. When his hares and partridges are actually on their way to the dealer's shop, he, "good easy man," may fancy that they are merely on a visit to his neighbour's manor, or that the fox and the polecat may have made free with them. Not so with regard to the capture of the pheasant. The mansion is sometimes beset; guns are fired close to the windows; females are frightened into hysterics; and, if the owner sallies forth to repel the marauders, his reception is often the most untoward and disagreeable that can well be imagined.

Having now treated of the pheasant, and the mode which is adopted for its destruction, I will draw upon the reader's time a little longer, by proposing a plan for its propagation and protection.

Pheasants would certainly be delightful ornaments to the lawn of the country gentleman, were it not for the annoying idea that, any night, from November to May, he runs the risk of getting a broken head, if he ventures out to disturb the sport of those who have assembled to destroy them. There must be something radically wrong in the game laws. How or when those laws are to be amended, is an affair of the legislature. The ornithologist can do no more than point out the grievance which they inflict upon society, and hope that there will soon be a change in them for the better. But to the point. Food and a quiet retreat are the two best offers that man can make to the feathered race, to induce them to take up their abode on his domain; and they are absolutely necessary 
to the successful propagation of the pheasant. This bird has a capacious stomach, and requires much nutriment; while its timidity soon causes it to abandon those places which are disturbed. It is fond of acorns, beech mast, the berries of the hawthorn, the seeds of the wild rose, and the tubers of the Jerusalem artichoke. As long as these, and the corn dropped in the harvest, can be procured, the pheasant will do very well. In the spring it finds abundance of nourishment in the sprouting leaves of young clover; but, from the commencement of the new year till the vernal period, their wild food affords a very scanty supply; and the bird will be exposed to all the evils of the vagrant act, unless you can contrive to keep it at home by an artificial supply of food. Boiled potatoes (which the pheasant prefers much to those in the raw state) and beans are, perhaps, the two most nourishing things that can be offered in the depth of winter. Beans, in the end, are cheaper than all the smaller kinds of grain; because the little birds, which usually swarm at the place where pheasants are fed, cannot swallow them; and, if you conceal the beans under yew or holly bushes, or under the lower branches of the spruce fir tree, they will be out of the way of the rooks and ringdoves. About two roods of the thousand-headed cabbage are a most valuable acquisition to the pheasant preserve. You sow a few ounces of seed in April, and transplant the young plants, two feet asunder, in the month of June. By the time that the harvest is all in, these cabbages will afford a most excellent aliment to the 
pheasants, and are particularly serviceable when the ground is deeply covered with snow. I often think that pheasants are unintentionally destroyed by farmers during the autumnal seedtime. They have a custom of steeping the wheat in arsenic water. This must be injurious to birds which pick up the corn remaining on the surface of the mould. I sometimes find pheasants, at this period, dead in the plantations, and now and then take them up, weak and languid, and quite unable to fly.

I will mention, here, a little robbery by the pheasants, which has entirely deprived me of a gratification I used formerly to experience in an evenings' saunter down the vale. They have completely exterminated the grasshoppers. For these last fourteen years $I$ have not once heard the voice of this merry summer charmer in the park.

In order to render useless all attempts of the nocturnal poacher to destroy the pheasants, it is absolutely necessary that a place of security should be formed. I know of no position more appropriate than a piece of level ground, at the bottom of a hill, bordered by a gentle stream. About three acres of this, sowed with whins, and surrounded by a holly fence, to keep the cattle out, would be the very thing. In the centre of it, for the space of one acre, there ought to be planted spruce fir trees, about fourteen feet asunder. Next to the larch, this species of tree is generally preferred by the pheasants for their roosting place; and it is quite impossible that the poachers can shoot them in these trees. Moreover, magpies and jays will al- 
ways resort to them at nightfall; and they never fail to give the alarm, on the first appearance of an enemy. Many a time has the magpie been of essential service to me, in a night excursion after poachers. If there be no park wall, an eye ought to be kept, from time to time, on the neighbouring hedges. Poachers are apt to set horse-hair snares in them; and these villanous nooses give the pheasants apoplexy. Six or seven dozen of wooden pheasants, nailed on the branches of trees, in the surrounding woods, cause unutterable vexation and loss of ammunition to these amateurs of nocturnal plunder. Small clumps of hollies, and yew trees with holly hedges round them, are of infinite service, when planted at intervals of 150 yards. To these the pheasants fly, on the sudden approach of danger during the day, and skulk there till the alarm is over. When incubation is going on, the diurnal poachers make great havoc among the pheasants' eggs. They sell sittings of them for five shillings (and sometimes for ten, if the risk in procuring them be great), to gentlemen in towns, who place them under bantam hens. If to these arrangements for protecting pheasants there could be added a park wall from nine to ten feet high, and including about 250 acres, consisting of wood, meadow, pasture, and arable land, the naturalist might put all enemies at defiance, and revel in the enchanting scene afforded by the different evolutions of single pairs, and congregated groups, of animated nature. Unmolested by packs of liounds, unbroken in upon by idle boys, and unannoyed by stray cattle, 
and by those going in search of them, his wildfowl would never desert the pool till their day of migration arrived; and his pheasants (except for the purpose of incubation, and then in no great quantities) would seldom rove beyond the protected enclosure.

The teal and wigeons stay with me till the last week in April; long after the pochards and the main flocks of mallards have winged their flight to northern polar regions; and a white male pheasant has taken up his abode here, for seven years, without having been once seen to wander half a mile from the house.

Birds thus protected have very different habits from those which are exposed to the caprice and persecutions of man. When the ornithologist pays attention to them, in their safe retreat, where they can follow, without molestation, the impulse of that instinct which has been so bountifully given to them, he will have great cause to suspect that there is many an error, and many a false conclusion, in the works which we have at present, on the habits and economy of the feathered race. These errors are, no doubt, quite unintentional on the part of the writers on British ornithology; and can only be corrected by great care, and a frequent personal attendance at those places where birds are encouraged and befriended. 


\section{HABITS OF THE JACKDAW.}

THIs lively bird is the constant friend and companion of the rook, in our part of Yorkshire, for nine months out of twelve; and, I think, there is no doubt but that it would remain with the rook for the other three if it only had that particular kind of convenience for incubation which its nature, for reasons totally unknown to us, seems to require.

Though the jackdaw makes use of the same kind of materials for building as those which are found in the nest of the rook; though it is, to all appearance, quite as hardy a bird; and though it passes the night, exposed to the chilling cold and rains of winter, on the leafless branches of the lofty elm; still, when the period for incubation arrives, it bids farewell to those exposed heights where the rook remains to hatch its young, and betakes itself to the shelter which is afforded in the holes of steeples, towers, and trees. Perhaps there is no instance in the annals of ornithology which tells of the jackdaw ever building its nest in the open air. Wishing to try whether these two congeners could not be induced to continue the year throughout in that bond of society which, I had observed, was only broken during incubation, I made a commodious cavity in an aged elm, just at the place where it had lost a mighty limb, some forty years ago, in a tremendous gale of wind wlich laid prostrate 
some of the finest trees in this part of Yorkshire. At the approach of breeding-time, a pair of jackdaws took possession of it, and reared their young in shelter; while the rooks performed a similar duty on the top of the same tree, exposed to all the rigours of an English spring. This success induced me to appropriate other conveniences for the incubation of the jackdaw: and I have now the satisfaction to see an uninterrupted fellowship exist, the year throughout, between the jackdaw and the rook.

Those who are of opinion that birds are gifted with a certain portion of reasoning, superior to that which is usually denominated instinct, will have cause for reflection, should they ever examine the materials of a jackdaw's nest, or pay any attention to the mode by which the bird tries to introduce those materials into the hole. The jackdaw invariably carries into it a certain quantity of sticks, fully as thick as those which are made use of by the rook. Now, it always occurs to us that the rook conveys sticks up to the branches of a tree in order to make a kind of frame which may support the inner parts of the nest. But why should the jackdaw deposit a large heap of strong sticks in the hole which is already calculated to support every kind of material proper for a nest? Then, again : how the act itself of introducing those apparently useless sticks causes us to suspend our judgment, before we finally conclude that the bird is endowed with any sort of reasoning superior to what is commonly denominated the instinct of brutes! You 
may see the jackdaw trying, for a quarter of an hour, to get a stick into the hole; while every attempt will be futile, because, the bird having laid hold of it by the middle, it is necessarily thrown at right angles with the body; and the daw cannot possibly perceive that the stick ought to be nearly parallel with its body, before it can be conveyed into the hole. Fatigued at length with repeated efforts, and completely foiled in its numberless attempts to introduce the stick, it lets it fall to the ground; and immediately goes in quest of another, probably to experience another disappointment on its return. When time and chance have enabled it to place a quantity of sticks at the bottom of the hole, it then goes to seek for materials of a more pliant and a softer nature.

The shrill and quickly repeated notes of the jackdaw, especially during incubation, are far from being unpleasant to the ear which is accustomed to rural sounds ; but very few people have an opportunity of paying attention to them, as this bird is by no means a general favourite with man. It is commonly accused of sucking eggs : but eggs form no part of its diet, otherwise it would be a bad neighbour here; and ringdoves, house-doves, wagtails, fowls, and ducks would wish it far away. It is vastly fond of peas and cherries. When these are done, the jackdaw repairs to the pastures, where it devours an incredible number of insects.

After the young have left the nest, they join the rooks, and roost with them in the surrounding woods till near the autumnal equinox; when both 
rooks and jackdaws regularly retire at nightfall to the eastward of this place, in immense flocks, and return to the westward every morning for the ensuing half year.

The jackdaw lays from four to six eggs, varying very much in colour, and often in size and shape. When protected, it will build its nest in holes not above six feet from the ground, where people are passing and repassing every hour of the day. If you take away the eggs, and substitute those of magpies, the bird will hatch them, and rear the young ones with great care and affection.

The plumage of the jackdaw is black, with shining silvery grey behind the head, changing when exposed to the different rays of light. A jackdaw once appeared here with a remarkable portion of white in one of the wings; it tarried with us for two years, and then disappeared for ever. Probably the singularity of its wing had attracted the fatal notice of some experienced gunner, in its peregrinations beyond this vale of safety.

The jackdaw, like the rook, collects insects in its mouth, to feed its young; and this gives it the appearance of a pouch under the lower mandible.

I know not how far naturalists will agree with me in the speculation that these birds remain in pairs the year througliout. When November's winds have stripped the sycamore of its every leaf, I see the daws sitting in pairs, side by side, upon the naked branches. They seem fond of preening 
each other's heads; and, as they mostly leave the trees in pairs, and in pairs return, I am led to conjecture that their union is not dissolved at the period when the young no longer need parental aid.

He who is fond of rural scenes, and loves to rove

" On a mountain's lonely van, Beyond the noise of busy man. Painting fair the form of things, While the yellow linnet sings, Or the tuneful nightingale Charms the forest with her tale,"

will never bring his mind to drive away this playful merry bird, or allow his gardener to take its life, for the value of a handful of cherries.

DEFENCE AGAINST ANIMALS OF THE FELINE AND CANINE TRIBES.

A MAN, at some period or other of his life, may have the misfortune to come in contact with the larger individuals of these two desperate and sanguinary races of quadrupeds. Perhaps a few hints of a precautionary nature, in case of collision, may not be altogether unacceptable to the reader.

The dog and the lion are both most formidable foes to an unarmed man; and it is singular enough that the very resistance which he would be forced to make, in order to escape being worried by the 
former, would inevitably expose him to certain destruction from the claws and teeth of the latter.

All arimals of the dog tribe must be combated with might and main, and with unceasing exertion, in their attacks upon man: for, from the moment they obtain the mastery, they worry and tear their victim as long as life remains in it. On the contrary, animals of the cat tribe having once overcome their prey, they cease for a certain time to inflict further injury on it. 'Thus, during the momentous interval from the stroke which has laid a man beneath a lion, to the time when the lion shall begin to devour him, the man may have it in his power to rise again, either by his own exertions, or by the fortuitous intervention of an armed friend. But then all depends upon quiet, extreme quiet, on the part of the man, until he plunges his dagger into the heart of the animal ; for if he tries to resist, he is sure to feel the force of his adversary's claws and teeth with redoubled rengeance. Many years ago, Colonel Duff, in India, was laid low by the stroke of a Bengal tiger. On coming to himself he found the animal standing over him. Recollecting that he had his dirk by his side, he drew it out of the case in the most cautious manner possible, and by one happy thrust quite through the heart, he laid the tiger dead at his side.

I will here mention a trivial row I once had with two dogs. It will tend to prove the advantage of standing up manfully when attacked by animals of the canine tribe ; and I will conclude with recount- 
ing an adventure with a lion, perhaps unparalleled in the annals of hunting.

Towards the close of the year 1823, in passing over a common, I accidentally came upon two dogs. One of them was a stout, ill-looking, uncouth brute, apparently of that genealogy which dog-fanciers term half bull and half terrier; the other was an insignificant female cur. The dog immediately bristled up, and I had just time to take off my hat, and hold it shieldwise in self-defence, when he came on and made directly at it. I gave him a hearty kick under the breast, which caused him to desist for a moment. But he stoutly renewed the attack, which was continued for above five minutes; he always flying at the hat, and I regularly repeating my kicks, sometimes slightly, sometimes heavily, according to our relative situations. In the mean time the female cur was assailing me from behind, and it was with difficulty that I succeeded in keeping her clear of me, by means of swinging my foot backwards at her. At last, a lucky blow on her muzzle from the heel of my shoe caused her to run away howling, and the dog immediately followed her, just at the moment when two masons were coming up to assist me. Thus, by a resolute oppo. sition I escaped laceration. But this little affair is scarcely worth relating, except that it affords a proof of the advantage to be derived from resisting the attack of a dog to the utmost.

And now for the feline tribe. The story which I am about to recount, will show that nonresistance was the only plan to be pursued when escape from 
death seemed utterly hopeless. The principals in this affair were a brave young British officer and a full-grown lion of India. I was at Frankfort on the Mayne in August last, and I heard the account from the officer's own mouth. I shall never forget the affable and unassuming manner in which he related it to me. I repeatedly urged him to allow me to put it on record, and at the same time to make use of his name; but I plainly saw that his feelings were against his complying with my request; and I think I should not have succeeded, had I not luckily brought to my assistance the plea of benefit to natural history. With this I conquered the objections of the young soldier; and I only wish that it had fallen to an abler pen than mine to relate the following adventure.

In the month of July, 1831, two fine lions made their appearance in a jungle some twenty miles distant from the cantonment of Rajcoté, in thè East Indies, where Captain Woodhouse, and his two friends, Lieutenants Delamain and Lang, were stationed. An elephant was despatched to the place in the evening on which the information arrived; and on the morrow, at the break of day, the three gentlemen set off on horseback, full of glee, and elated with the hope of a speedy engagement. On arriving at the edge of the jungle, people were ordered to ascend the neighbouring trees, that they might be able to trace the route of the lions in case they left the cover. After beating about in the jungle for some time, the hunters started the two 
lordly strangers. The cfficers fired immediately, and one of the lions fell to rise no more. His companion broke cover, and took off across the country. The officers now pursued him on horseback as fast as the nature of the ground would allow, until they learned from the men who were stationed in the trees, and who held up flags by way of signal, that the lion had gone back into the thicket. Upon this the three officers returned to the edge of the jungle, and having dismounted from their horses, they got upon the elephant; Captain Woodhouse placing himsclf in the hindermost seat. They now proceeded towards the heart of the jungle, in the expectation of rousing the royal fugitive a second time. They found him standing under a large bush, with his face directly towards them. The lion allowed them to approach within range of his spring, and then he made a sudden dart at the elephant, clung on his trunk with a tremendous roar, and wounded him just above the eye. While he was in the act of doing this, the two lieutenants fired at him, but without success. The elephant now shook him off; but the fierce and sudden attack on the part of the lion seemed to have thrown him into the greatest consternation. This was the first time he had ever come in contact with so formidable an animal; and much exertion was used before his riders succeeded in urging him on again in quest of the lion. At last he became somewhat more tractable; but as he was advancing through the jungle, all of a sudden the lion, which had lain concealed in the high grass, made at him with redoubled fury. 
The officers now lost all hopes of keeping their elephant in order. He turned round abruptly, and was going away quite ungovernable, when the lion again sprang at him, seized his hinder parts with his teeth, and hung on them until the affrighted animal managed to shake him off by incessant kicking.

The lion retreated farther into the thicket ; Captain Woodhouse in the meantime firing a random shot at him, which proved of no avail, as the jolting of the elephant and the uproar of the moment prevented him from taking a steady aim. No exertions on the part of the officers could now force the terrified elephant to face his fierce foe, and they found themselves reduced to the necessity of dismounting. Determined, however, to come to still closer quarters with the formidable king of quadrupeds, Capt. Woodhouse took the desperate resolution to proceed on foot in quest of him; and after searching about for some time, he observed the lion indistinctly through the bushes, and discharged his rifle at him; but he was pretty well convinced that he had not hit him, for he saw the lion retire with the utmost composure into the thicker parts of the brake. The two lieutenants, who had remained at the outside of the jungle, joined their companion on hearing the report of his gun.

The weather was intolerably sultry. After vainly spending a considerable time in creeping through the grass and bushes, with the hope of discovering the place of the lion's retreat, they concluded that he had passed quite through the jungle, and gone 
off in an opposite direction. Resolved not to let their game escape, the lieutenants returned to the elephant, and immediately proceeded round the jungle, expecting to discover the route which they conjectured the lion had taken. Captain Woodhouse, however, remained in the thicket; and as he could discern the print of the animal's feet on the ground, he boldly resolved to follow up the track at all hazards. The Indian gamefinder, who continued with his commander, at last espied the lion in the cover, and pointed him out to the captain, who fired, but unfortunately missed his mark. There was now no alternative left but to retreat and load his rifle. Having retired to a distance, he was joined by Lieutenant Delamain, who had dismounted from his elephant on hearing the report of the gun. This unexpected meeting inereased the captain's hopes of ultimate success. He lost no time in pointing out to the lieutenant the place where he would probably find the lion, and said he would be up with him in a moment or two.

Lieutenant Delamain, on going eight or ten paces down a sheep track, got a sight of the lion, and instantly discharged his rifle at him.

"Impetus est fulvis, et vasta leonibus ira!"

This irritated the mighty lord of the woods, and he rushed towards him, breaking through the bushes (to use the captain's own words) " in most magnificent style." Captain Woodhouse now found himself placed in a awkward situation. He was aware that if he retraced his steps in order to put himself 
in a better position for attack, he would just get to the point from which the lieutenant had fired, and to which the lion was making; wherefore he instantly resolved to stand still, in the hopes that the lion would pass by, at a distance of four yards or so, without perceiving him, as the intervening cover was thick and strong. In this, however, he was most unfortunately deceived; for the enraged lion saw him in passing, and flew at him with a dreadful roar. In an instant, as though it had been done by a stroke of lightning, the rifle was broken and thrown out of the captain's hand, his left arm at the same moment being seized by the claws, and his right by the teeth, of his desperate antagonist. While these two brave and sturdy combatants, "whose courage none could stain," were yet standing in mortal conflict, Lieutenant Delamain ran up, and discharged his piece full at the lion. This caused the lion and the captain to come to the ground together, while Lieutenant Delamain hastened out of the jungle to reload his gun. The lion now began to craunch the captain's arm; but as the brave fellow, notwithstanding the pain which this horrid process caused, had the cool determined resolution to lie still, the lordly savage let the arm drop out of his mouth, and quietly placed himself in a couching position, with both his paws upon the thigh of his fallen foe. While things were in this untoward situation, the captain unthinkingly raised his hand to support his head, which had got placed ill at ease in the fall. No sooner, however, had he moved it, than the lion seized the lacerated arm a 
second time, craunched it as before, and fractured the bone still higher up. This additional memento mori from the lion was not lost upon Captain Woodhouse; it immediately put him in mind that he had committed an act of imprudence in stirring. The motionless state in which he persevered after this broad hint, showed that he had learned to profit by the painful lesson.

He now lay bleeding and disabled under the foot of a mighty and an irritated enemy. Death was close upon him, armed with every terror calculated to appal the heart of a prostrate and defenceless man. Just as this world, with all its flitting honours, was on the point of vanishing for ever, he heard two faint reports of a gun, which he thought sounded from a distance; but he was totally at a loss to account for them. He learned, after the affair was over, that the reports were caused by his friend at the outside of the jungle, who had flashed off some powder in order to be quite sure that the nipples of his rifle were clean.

The two lieutenants were now hastening to his assistance, and he heard the welcome sound of feet approaching; but, unfortunately, they were in a wrong direction, as the lion was betwixt them and him. Aware that if his friends fired, the balls would hit him, after they had passed through the lion's body, Captain Woodhouse quietly pronounced, in a low and subdued tone, "to the other side! to the other side!" Hearing the voice, they looked in the direction from whence it proceeded, and to their horror saw their brave comrade in his utmost 
need. Having made a circuit, they cautiously came up on the other side, and Lieutenant Delamain, whose coolness in encounters with wild beasts had always been conspicuous, from a distance of about a dozen yards, fired at the lion over the person of the prostrate warrior.

The lion merely quivered; his head dropped upon the ground, and in an instant he lay dead on his side close to his intended victim. The lieutenant's aim was so good and true, that it puts one in mind of what happened at Chevy Chase;

"Against Sir Hugh Montgomery

So right the shaft was set,

The grey goose wing that was thereon

In bis heart's blood was wet!"

Thus endêd this ever-memorable homo-leonine encounter. I beg to return my thanks to Captain Woodhouse for allowing me to avail myself of it. From what has been related, a proof may be drawn of the utility of lying quite still when we have the misfortune to be struck to the ground by an animal of the cat tribe.

I bade a long farewell to Captain Woodhouse and his two friends, Messrs. Kavanagh and Pontardent, at Frankfort on the Mayne. They were on their way to India, through. Vienna and Constantinople. May honours, health, and wealth attend them! 
AERIAL ENCOUNTER OF THE EAGLE AND THE VULTURE.

Next to the adventure of the rattlesnake and squirrel, in which Audubon informs us that he saw a rattlesnake swallow a large American squirrel, tail foremost, I am of opinion that this presents the toughest morsel ever offered to the proverbially widle gullet of John Bull. Audubon says :- "Many vultures were engaged in devouring the body and entrails of a dead horse, when a white-headed eagle accidentally passing by, the vultures all took to wing, one, amongst the rest, with a portion of the entrails, partly swallowed, and the remaining part, about a yard in length, dargling in the air. The eagle instantly marked him, and gave chase. The poor vulture tried, in vain, to disgorge, when the eagle, coming up, seized the loose end of the gut, and dragged the bird along for twenty or thirty yards, much against its will, till both fell to the ground; when the eagle struck the vulture, and in a tew moments killed it, after which he swallowed the delicious norsel." In lis strange paper on the habits of the turkey buzzard, Mr. Audubon tells us "that if the object discovered is large, lately dead, and covered with a skin too tough to be ate and torn asunder (cart before the horse), and afford free scope to their appetites, they remain about it and in the neighbourlood." Now, reader, observe, 
that, the dead horse being a large animal, its skin, according to this quotation, must have been too tough to be torn asunder by the vultures, until putrefaction took place. If, then, these vultures really commenced devouring the dead animal while it was yet fresh, Mr. Audubon's theory, just quoted, is worth nothing. If, on the contrary, the horse in question had become sufficiently putrid to allow the vultures to commence operations, then I will show that the aërial account of the eagle and the vulture is eitlıer a mere imaginary effusion of the author's fancy, or a hoax played off upon his ignorance by some designing wag.

The entrails of a dead animal are invariably the first part to be affected by putrefaction. Now, we are told that a piece of gut had been torn from the rest, and swallowed by the vulture; a portion of the said gut, about a yard in length, hanging out of his mouth. The vulture, pressed hard by the eagle, tried in vain to disgorge the gut. This is at variance with a former statement, in which Mr. Audubon assures us that an eagle will force a vulture to disgorge its food in a moment: so that the validity of this former statement must be thrown overboard, in order to insure the safety of the present adventure; or, vice versâ, the present adventure must. inevitably sink, if the former statement is to be preserved. Be this as it may, the eagle, out of all manner of patience at the clumsiness of the vulture, in his attempt to restore to daylight that part of the gut which was lying at the bottom of his stomach, laid hold of the end which was still hanging 
out of the unfortunate rascal's mouth, and actually dragged him along through the air, for a space of twenty or thirty yards, much against the vulture's will. Now, though the eagle pulled, and the vulture resisted, still the yard of gut, which we must suppose was in a putrid state, for reasons already mentioned, remained fixed and firm in the vulture's bill. With such a force, applied to each extremity, the gut ought either to have given way in the middle, or to have been cut in two at those places where the sharp bills of the birds held it fast. - But stop, reader, I pray you: speculation might be allowed here, provided this uncommon encounter had taken place on terra firma; but, in order that our astonishment may be wound up to the highest pitch, we are positively informed that the contention took place, not on the ground, or in a tree, but in the circumambient air!

Pray, how was it possible for the eagle to progress through the air, and to have dragged along a resisting vulture, by means of a piece of gut acting as a rope, about a yard in length? Birds cannot fly backwards; and the very act of the eagle turning round to progress after it had seized the end of the gut, would have shortened the connecting medium so much, that the long wings of both birds must have immediately come in contact; their progress would have been prevented by the collision; and, in lieu of the eagle dragging the resisting vulture through the air, for a space of twenty or thirty yards, both birds would have come to the ground, or the gut would have given way. 
I have never read any thing in the annals of ornithology that bcars any similarity to this aquilavulturian exhibition progressing through the vault of heaven. Verily, "there is a freshness in it."

When we reflect that $\mathrm{Mr}$ Audubon is an American; that he has lived the best part of his life in America; that the two birds themselves were American, and that their wonderful encounter took place in America, we Englishmen marvel much that Mr. Audubon did not allow the press of his own country to have the honour to impart to the world so astonishing an adventure.

\section{THE HUMMING-BIRD.}

Mr. Audubon tells us, that in one week the young of the ruby-throated humming-bird are ready to fly. One would suppose, by this, that they must be hatched with a good coating of feathers to begin with. Old Dame Nature sometimes performs odd pranks. We are informed that our crooked-back Dicky the Third was born with teeth; and Ovid mentions the astonishingly quick growth of certain men. He says, in his account of the adventures of Captain Cadmus, who built Thebes, that the captain employed some men as masons who had just sprung up out of the earth.

I have read Mr. Audubon's account of the growth 
of the humming-bird, and I have read Mr. Ovid's account of the growth of Captain Cadmus's masons, and both very attentively. I think the veracity of the one is as apparent as the veracity of the other. What, in the name of skin and feathers, I ask, has Mr. Audubon found in the economy of the rubythroated humming-bird to enable him to inform Englishmen that its young can fly in so short a space of time? The young of no other bird that we are acquainted with, from the condor to the wren, can fly when only a week old.

The humming-bird, in every part of its body and plumage, is quite as perfect as the eagle itself; neither is it known to differ in the duration of its life from any of the smaller birds of the forest which it inhabits. Like them, it bursts the shell in a state of nudity; like them, it is blind for some days; and, like them, it has to undergo the gradual process of fledging, which is so slow in its operation, that I affirm, without fear of refutation, it cannot possibly produce, in the space of one short week, a series of feathers capable of supporting the bird through the air.

Again, the precocious flying of the young birds, argues precocity of feathers; and this would authorise us to look for precocity of lustre in the male. But Mr. Audubon informs us that the male does not receive its full brilliancy of colour until the succeeding spring; and I myself can affirm, from actual observation, that the additional plumage which adorns some humming-birds does not make its appearance till towards the middle of the second year. 
Were it necessary, I could show to naturalists their error, in sometimes mistaking a male hummingbird of the first year for a full-plumaged female. I am fully satisfied in my own mind that the internal anatomy of all humming-birds is precisely the same, except in size; having found it the same in every humming-bird which I dissected in Guiana and Brazil. Now, as the young of the humming-birds in these countries require more than a week to enable them to $\mathrm{fly}$, and as Mr. Audubon's humming-bird differs not in internal anatomy from them, I see no reason why the young of his species should receive earlier powers of flying than the young of the humming-birds in the countries just mentioned.

A word on the cradle. Mr. Audubon tells us, that the little pieces of lichen, used in forming the nest of the humming-bird, "are glued together with the saliva of the bird." Fiddle! The saliva of all birds immediately mixes with water. A single shower of rain would undo all the saliva-glued work on the nest of Mr. Audubon's humming-bird. When our great master in ornithology (whose writings, according to Swainson, will be read when our favourite theories shall have sunk into oblivion) saw his humming-bird fix the lichen to the nest, pray what instrument did it make use of, in order to detach the lichen from the point of its own clammy bill and tongue; to which it would be apt to adhere just as firmly as to the place where it was intended that it should permanently remain? 


\section{THE VIRGINIAN PARTRIDGE.}

"Nantes in gurgite vasto." Virgil.

" LIKE the turkeys, many of the weaker partridges often fall into the water while thus attempting to cross, and generally perish; for, although they swim surprisingly, they lave not muscular power sufficient to keep up a protracted struggle." (See Biography of Birds, p. 388.)

Birds which can "swim surprisingly" will never "perish" by the act of swimming; neither would they be under the necessity of having recourse to " a protracted struggle" in a movement which requires no struggle at all. A bird struggling in the act of swimming, in order to save itself from drowning, is about the same as if we were to struggle in our usual act of walking, lest we perish therein. The very mention of "a protracted struggle" argues that the partridge cannot swim. A partridge on the water is nearly in as great a scrape as a shark on shore. The latter, by floundering, may, perchance, get into the water again; still we cannot say that a shark moves surprisingly on land: and the former, by help of its feet, may possibly reach the river's bank, through an element as fatal to it as the shore is to the shark. All birds, whether alive or dead, must naturally float on the surface of the water; but all birds cannot swim: otherwise those birds which we commonly call land birds would have to be new-modelled in form, and would require a very different kind of plumage.

We startle at the novel information of a partridge "swimming surprisingly," and we are anxious to 
know what sudden change has taken place amongst the birds in the western hemisphere, whilst our eastern birds remain in statu quo. For example's sake, let us examine a waterhen, which, like the partridge, is not web-footed; still it swims remarkably well. Its body is nearly similar in shape to a boat; the arrangement of its feathers is most admirably calculated to resist the entrance of the water; while its every motion, when in the act of swimming, is full of gracefulness and confidence. It moves to and fro by a very gentle action of the feet, and it may be seen, for hours together, enjoying itself on the deep; in perfect security. This bird may be truly said to swim surprisingly; but it is never doomed to keep up a protracted struggle by means of muscular power, in order to save its life, on an element where it runs no risk of perishing.

Now let us look at a partridge floating on the river. The form of its body is very unlike that of the waterhen, and though it cannot possibly sink, still it is in the utmost fear of death, and tries to reach the shore by an evident and vehement struggle. Its feathers immediately become saturated with water, whilst the cold strikes deeply into its body. Death is fast approaching; the wings are soaked with flapping on the water, and at last appear extended quite motionless on the surface of the stream; the legs are cramped and stiffened; the mouth is open; the head falls, and, after a few convulsive efforts to support itself, down it drops for the last time into the water, and the bird dies. This is the fate of the partridge, which Mr. Audubon assures 
us can "swim surprisingly." The mere motion of its legs, to propel its floating body towards land, in order to escape from certain death on an element where it was never intended by Nature to exist, even for the space of one short hour, has been magnified by Mr. Audubon into an important act of "swimming surprisingly."

If the admirers of Mr. Audubon should try to force us to agree with their great naturalist, that partridges can "swim surprisingly," then it behoves us to call upon them to declare that every bird in the creation can swim. Our little tomtit, till now a land bird, must be proclaimed to swim surprisingly, and have a place amongst the waterfowl; because, on tumbling accidentally into a washing-tub, he has " muscular power sufficient to keep up a protracted struggle" till he reaches the side.

\section{ON THE HABITS OF THE ROOK.}

LAST year I partly promised that, on some dismal winter's evening, I would sit me down, and write the history of the rook. The period has now arrived. Nothing can be more gloomy and tempestuous than the present aspect of the heavens. The wind is roaring through the naked branches of the sycamores, the rain beats fiercely on the eastern windows, and the dashing of the waves against the walls of the island, warns us that one of November's dark and stormy nights is close at hand; such a night, probably, as that in which 
Tam O'Shanter unfortunately peeped into Kirk Alloway. Foreigners tell us that on these nights Englishmen are prone to use the knife, or a piece of twisted hemp, to calm their agitated spirits. For my own part, I must say that I have an insuperable repugnance to such anodynes; and, were a host of blue devils, conjured up by November's fogs, just now to assail me, I would prefer combating the phantoms with the weapons of ornithology, rather than run any risk of disturbing the economy of my jugular vein, by a process productive of very unpleasant sensations, before it lulls one to rest.

According to my promise, I will now pen down a few remarks on the habits of the rook, which bird, in good old sensible times, was styled frugilegus. It is now pronounced to be pradatorius. Who knows but that our Great Ones in Ornithology, may ultimately determine to call it up to the house of hawks?

If this useful bird were not so closely allied to the carrion crow in colour and in shape, we should see it sent up to the tables of the rich, as often as we see the pigeon. But prejudice forbids the appearance of broiled rook in the lordly mansion. If we wish to partake of it, we must repair to the cottage of the lowly swain, or, here and there, to the hall of the homely country squire, whose kitchen has never been blessed by the presence of a first-rate cook, and whose yearnings for a good and wholesome dish, are not stifled by the fear of what a too highly polished world will say.

There is no wild bird in England so completely gregarious as the rook; or so regular in its daily 
movements. The ringdoves will assemble in countless multitudes, the finches will unite in vast assemblies, and waterfowl will flock in thousands to the protected lake, during the dreary months of winter: but, when the returning sun spreads joy and consolation over the face of nature, their congregated numbers are dissolved, and the individuals retire in pairs to propagate their respective species. The rook, however, remains in society the year throughout. In flocks it builds its nest, in flocks it seeks for food, and in flocks it retires to roost.

About two miles to the eastward of this place are the woods of Nostell Priory, where, from time immemorial, the rooks have retired to pass the night. I suspect, by the observations which I have been able to make on the morning and evening transit of these birds, that there is not another roosting-place for, at least, thirty miles to the westward of Nostell Priory. Every morning, from within a few days of the autummal, to about a week before the vernal equinox, the rooks, in congregated thousands upon thousands, fly over this valley in a westerly direction, and return, in undiminished numbers, to the east, an hour or so before the night sets in. In their morning passage, some stop here; others, in other favourite places, farther and farther on; now repairing to the trees for pastime, now resorting to the fields for food, till the declining sun warns those which have gone farthest to the westward that it is time they should return. They rise in a mass, receiving additions to their numbers from every intervening place, till they reach this neighbourhood in 
an amazing flock. Sometimes they pass on without stopping, and are joined by those which have spent the day here. At other times they make my park their place of rendezvous, and cover the ground in vast profusion, or perch upon the surrounding trees. After tarrying here for a certain time, every rook takes wing. They linger in the air for a while, in slow revolving circles, and then they all proceed to Nostell Priory, which is their last resting-place for the night. In their morning and evening passage, the loftiness or lowliness of their flight, seems to be regulated by the state of the weather. When it blows a hard gale of wind, they descend the valley with astonishing rapidity, and just skim over the tops of the intervening hills, a few feet above the trees: but, when the sky is calm and clear, they pass through the heavens at a great height, in regular and easy flight.

Sometimes these birds perform an evolution, which is, in this part of the country, usually called the shooting of the rooks. Farmers tell you, that this shooting portends a coming wind. He who pays attention to the flight of birds has, no doubt, observed this downward movement. When rooks have risen to an immense height in the air, so that, in appearance, they are scarcely larger than the lark, they suddenly descend to the ground, or to the tops of trees exactly under them. To effect this, they come headlong down, on pinion a little raised, but not expanded, in a zig-zag direction (presenting, alternately their back and breast to you), through the resisting air, which causes a noise similar to that of a rushing 
wind. This is a magnificent and beautiful sight to the eye of an ornithologist. It is idle to suppose for a moment that it portends wind. It is merely the ordinary descent of the birds to an inviting spot beneath them, where, in general, some of their associates are already assembled, or where there is food to be procured. When we consider the prodigious height of the rooks at the time they begin to descend, we conclude that they cannot effect their arrival at a spot perpendicular under them, by any other process so short and rapid.

Rooks remain with us the year throughout. If there were a deficiency of food, this would not be the case ; for, when birds can no longer support themselves in the place which they have chosen for their residence, they leave it, and go in quest of nutriment elsewhere. Thus, for want of food, myriads of wild fowl leave the frozen north, and repair to milder climates; and in this immediate district, when there is but a scanty sprinkling of seeds on the whitethorn bush, our flocks of fieldfares and of redwings bear no proportion to those in times of a plentiful supply of their favourite food, But the number of rooks never visibly diminishes; and on this account we may safely conclude that, one way or other, they always find a sufficiency of food. Now, if we bring, as a charge against them, their feeding upon the industry of man, as, for example, during the time of a hard frost, or at seedtime, or at harvest, at which periods they will commit depredations, if not narrowly watched; we ought, in justice, to put down in their favour the rest of the year, when they feed entirely upon in- 
sects. Should we wish to know the amount of noxious insects destroyed by rooks, we have only to refer to a most valuable and interesting Paper on the Services of the Rook, signed T. G. Clitheroe, Lancashire, which is given in the Mag. of Nat. Hist., vol. vi. p. 142. I wish every farmer in England would read it: they would then be convinced how much the rook befriends them.

Some author (I think, Goldsmith) informs us, that the North American colonists got the notion into their heads that the purple grakle was a great consumer of their maize; and these wise men of the west actually offered a reward of threepence for the killed dozen of the plunderers. This tempting boon soon caused the country to be thinned of grakles, and then myriads of insects appeared, to put the good people in mind of the former plagues of Egypt. They damaged the grass to such a fearful extent, that, in 1749 , the rash colonists were obliged to procure hay from Pennsylvania, and even from England. Buffon mentions, that grakles were brought from India to Bourbon, in order to exterminate the grasshoppers. The colonists, seeing these birds busy in the new-sown fields, fancied that they were searching for grain, and instantly gave the alarm. The poor grakles were proscribed by Government, and in two hours after the sentence was passed, not a grakle remained in the island. The grasshoppers again got the ascendency, and then the deluded islanders began to mourn for the loss of their grakles. The governor procured four of these birds from India, about eight years after their proscription, and 
the state took charge of their preservation. Laws were immediately framed for their protection; and, lest the people should have a hankering for grakle pie, the physicians were instructed to proclaim the flesh of the grakle very unwholesome food. Whenever I see a flock of rooks at work in a turnip-field, which, in dry weather, is often the case, I know that they have not assembled there to eat either the turnips or the tops, but that they are employed in picking out a grub, which has already made a lodgment in the turnip.

Last spring, I paid a visit, once a day, to a carrion crow's nest on the top of a fir tree. In the course of the morning in which she had laid her fifth egg, I took all the eggs out of the nest, and in their place I put two rooks' eggs, which were within six days of being hatched. The carrion crow attended on the stranger eggs, just as though they had been her own, and she raised the young of them with parental care. When they had become sufficiently large, I took them out of the nest, and carried them home. One of them was sent up to the gamekeeper's house, with proper instructions; the other remained with me. Just at this time an old woman had made me a present of a barn-door hen. "Take it, sir," said she, "and welcome; for, if it stays here any longer, we shall be obliged to kill it. When we get up to wash in the morning, it crows like a cock. All its feathers are getting like those of a cock; it is high time that it was put out of the way, for when hens turn cocks people say that they are known to be very unlucky; and, if this thing is 
allowed to live, we don't know what may happen. It has great spurs on its legs, and last summer it laid four eggs. If I had had my own way, it would have been killed when it first began to crow." I received the hen with abundant thanks; and, in return, I sent the old woman a full-bred Malay fowl. On examining the hen, I found her comb very large; the feathers on the neck and rump much elongated; the spurs curved, and about $1 \frac{1}{4}$ inch long; the two largest feathers in her tail arched, and four or five smaller arched ones, of a beautiful and glossy colour, hanging down on each side of the tail. In a word, this hen had so masculine an appearance, that, when strangers looked at her, they all took her to be a cock, and it was with difficulty I persuaded them that she was a hen. We allowed her the range of a sheltered grass-plot, flanked on one side by holly trees, and open to the lake on the other. Here, also, was placed, in a cage, the young rook which I had taken from the nest of the carrion crow. The hen showed such an antipathy to it, that, whenever I held it to her, she would immediately fly at it. When visiters came to inspect her, I had only to take the rook out of the cage, and pit it against her, when she would stand upright, raise the long feathers on her neck, and begin to cackle, cluck, and crow. One morning the rook had managed to push aside a bar in front of its cage. A servant, in passing by, looked into it, and missed the bird. The hen had also disappeared. On search being made, they were both found floating side by side, dead, in the lake below. We conjectured that the hen had 
pursued the rook after its escape from the cage, and that the wind, which blew very strong that morning, had forced them both into a watery grave. I had still one rook left at the gamekeeper's. It was kept in a cage, which was placed on a little stand in his garden; and I had given orders that upon no account was it to be allowed to go at large. The feathers remained firm at the base of the bill till the 15th of August; on which day the keeper perceived that a few feathers had dropped from the lower mandible, and were lying at the bottom of the cage. In a couple of weeks more, the lower mandible had begun to put on a white scurfy appearance, while here and there a few feathers had fallen from the upper one. This is the purport of the keeper's information to me, on my return home from Bavaria. On the 31st of the same month, a terrible storm set in. By what the keeper told me, the night must have been as dark and dismal as that in which poor King Lear stood in lamentation, and exposed his hoary locks to the four rude winds of heaven. A standard white-heart cherry tree, perhaps the finest in Yorkshire, and which, for many generations, had been the pride and ornament of this place, lost two large branches during the gale; and in the morning, when the keeper rose, he found the cage shattered and upset, and driven to the farthest corner of his garden. The rook was quite dead. It had lost its life, either through the inclemency of that stormy night, or through bruises received in the fall of the cage. Thus both the rooks were unlucky. The old woman, no doubt, could clearly 
trace their misfortunes to her crowing hen. However, the experiment with the two young rooks, though not perfect, has nevertheless been of some use. It has shown us that the carrion crow makes no distinction betwixt its own eggs and those of the rook; that it can know nothing of the actual time required to sit upon eggs in order to produce the young; that the young of the rook will thrive under the care of the carrion crow, just as well as under that of its own parents; and finally, that the feathers fall off from the root of the rook's bill, by the order of nature, as was surmised by the intelligent Bewick, and not by the process of the bird's thrusting its bill into the earth, in search of food, as is the opinion of some naturalists.

The rook advances through the heavens with a very regular and a somewhat tardy beat of wing; but it is capable of proceeding with great velocity when it chooses : witness its pursuit and attack on the sparrowhawk and kestrel. It is apt to injure, in the course of time, the elm trees on which it builds its nest, by nipping off the uppermost twigs. But this, after all, is mere conjecture. The damage may be caused by an accumulation of nests, or by the constant resort of such a number of birds to one tree. Certain, however, it is, that, when rooks have taken possession of an elm tree for the purpose of incubation, the uppermost branches of that tree are often subject to premature decay.

Though the flocks of rooks appear to have no objection to keep company, from time to time, with the carrion crows, in a winter's evening, before they 
retire to roost, still I can never see a carrion crow build its nest in a rookery. There was always a carrion crow's nest here, in a clump of high Scotch pines, near the stables, till the rooks got possession of the trees; the carrion couple then forsook the place: the rooks were dislodged from this clump of trees; and then a pair of carrion crows (the same, for aught I know to the contrary) came and built their nest in it.

The rook lays from three to five eggs, varying much, like those of the carrion crow, in colour, shape, and size. After the rooks have built, and even lined their nests, they leave them, on the approach of night, to repair to the general rendezvous at Nostell Priory; but, as soon as they begin to lay, they then no longer quit the trees at night, until they have reared their young. When this has been effected, we see large flocks of them resorting to the different woods of the neighbourhood to pass the night. This they continue to do, till a few days before the autumnal equinox, when, for reasons which baffle all conjecture, they begin to pass over this valley every morning in a westerly direction, and return in the evening to their eastern roostingplace in the woods of Nostell Priory.

Rooks are observed to keep up a very close and friendly intercourse with starlings and jackdaws; but, on looking at them in the fields, the observer will perceive, that, while the jackdaws mix promiscuously with the rooks, both in their flight and in searching for food, the starlings always keep in their own flock. This circumstance has long engaged 
my attention; but I am no farther advanced in the investigation than I was on the first day on which I set out. It is one of the many secrets in the habits of birds, which will, perhaps, be for ever concealed from our view.

\section{THE PASSENGER PIGEON.}

"Towards the approach of day, the noise in some measure subsided; long before objects were distinguishable, the pigeons began to move off in a direction quite different from that in which they had arrived the evening before; and, at sunrise, all that were able to fly had disappeared. The howlings of the wolves now reached our ears, and the foxes, lynxes, cougars, bears, raccoons, opossums, and polecats were seen sneaking off." (Biography of Birds, by Audubon, p. 325.)

“Variarum monstra ferarum!" Virgil.

Mr. Audubon may boast of a sight never before seen by mortal eyes under similar circumstances. Great indeed must have been the yearning for pigeon flesh, to have caused such a variety of wild animals to assemble there; and irresistible the flavour which induced them to tarry so long beyond their wonted time of prowling. Their very nature seems to have been changed. Their remaining at the pigeon-slaughter till the time of sunrise is a most wonderful circumstance, which demands investigation on the part of naturalists; for, hitherto, all these wild beasts which Mr. Audubon 
has introduced into his description, have only been known as animals of nocturnal movements, and of very skulking and suspecting liabits. In general, the flash of a gun, the crackling of a flame, or the shout of a huntsman, will scare any one of them, even when concealed in the lonely retreat; but, on this ever-memorable occasion, the nerves of the animals, both large and small, were strung up to an astonishing degree of intensity. The day had already dawned, unheeded by them; and it was only at sunrise that they seemed aware of being in dangerous company, and found that it was high time to sneak off from a place where, Mr. Audubon tells us "there was little underwood;" where " the uproar continued the whole of the night;" where men had assembled "with iron pots, containing sulphur;" and "with torches of pine-knots, with poles and with guns;" where "fires were lighted, and a magnificent as well as wonderful and almost terrifying sight presented itself; "where, in fine, the auditory faculties of Mr. Audubon himself became so completely useless, on account of the stunning noise, that, absolutely, he was "only aware of the firing by seeing the shooters reloading." " $O$ judgment ! thou art fled to brutish beasts, and men have lost their reason," if they can bring themselves to believe that into this sulphureous, torch-lighted, detonating, yelling, roaring, and terrific attack on the passenger pigeons, there came up a motley herd of wolves, foxes, cougars, lynxes, bears, raccoons, opossums, and polecats, to share the plun- 
der, and actually tarried there till the rising of the sun;" at which time, Mr. Audubon informs us, they were seen sneaking off. He himself saw what he relates.

But let us pass on. "The pigeons," continues Mr. Audubon, "arriving by thousands, alighted everywhere, one above another, until solid masses as large as hogsheads were formed on the branches all around." Solid masses! Our European pigeons, in a similar situation, would have been all smothered in less than three minutes. Mr. Audubon informs us, towards the end of his narrative, that the feathers of this pigeon "fall off at the least touch." From this, we may infer to a certainty that every pigeon which was unlucky enough to be undermost in the solid masses would lose every feather from its uppermost parts, through the pressure of the feet of those above it. Now, I would fain believe that instinct taught these pigeons to resort to a certain part of the forest, solely for the purpose of repose, and not to undergo a process of inevitable suffocation; and, at the same time, to have their backs deprived of every feather, while they were voluntarily submitting to this self-inflicted method of ending their days.

"Many trees," says Mr. Audubon, "two feet in diameter, I observed, were broken off at no great distance from the ground; and the branches of many of the largest and tallest had given way, as if the forest had been swept by a tornado. Every thing proved to me that the number of birds resorting to this part of the forest must be 
immense beyond conception." I know that the force of a tornado will break the trunk of a tree two feet in diameter, because its force acts horizontally against the upright stem; but how is it possible that a multitude of pigeons, alighting upon a tree, could cause its upright bole, two feet in diameter, to break off at no great distance from the ground? The branches of the tree, which took their lead diagonally from the bole, might possibly have given way under a heavy pressure, because they were inclined more or less from their perpendicular; but the upright bole itself would stand uninjured, and defy for ever any weight that could be brought to bear upon it from above.

I now leave the assemblage of wild beasts, the solid masses of pigeons as large as hogsheads, and the broken trunk of the tree two feet in diameter, to the consideration of those British naturalists who have volunteered to support a foreigner in his exertions to teach Mr. Bull ornithology in the nineteenth century.

The passages upon which I have just commented form part of "the facts" on which R. B., in the Magazine of Natural History (vol. vi. p. 273.), tells us that the value of Mr. Audubon's Biography of Birds solely rests. No wonder that, ruit alto a culmine. By the way, I observe, at the end of that Biography, a most laudatory notice by Mr. Swainson. He tells us that Audubon contemplated Nature as she really is, not as she is represented in books: he sought her in her sanctuaries. Well, be it so; I do not dispute his 
word: still I suspect, that, during the search and contemplation, either the dame herself was in liquor, or her wooer in hallucination.

\section{A DESCRIPtion OF THE HABITS OF THE RINGDOVE.}

The supposed purity of the dove is a common topic with many writers; and their readers are apt to imagine that this bird has been more favoured by nature than the rest of the feathered tribe. What may be allowed to romantic and sentimental composers, cannot by any means be conceded to writers on natural history. Genuine Ornithology would be offended at the attempt to introduce unwarrantable matter into her pages; while her true votaries would always grieve on seeing it admitted into them.

All wild birds which go in pairs are invariably attached to each other by Nature's strongest ties; and they can experience no feelings of what may be called mistrust or suspicions of unfaithfulness; otherwise we should witness scenes of ornithological assault and battery in every hedge and wood, during the entire process of their incubation. The soot-black crow is just as chaste, affectionate, and constant as the snow-white dove itself. The movements of both these birds, at a certain time of the year, tend exactly to the same point. They are 
inherent and unalterable in them, and, of course, are not to be repressed or changed. At the interesting period of incubation, Nature knows no distinction betwixt the cooing of the dove and the cackling of the goose. Both sounds express the same emotions, and are perfectly understood by the parties. They have only one plain and obvious meaning. Audubon's description of his love-sick turtle-dove, which listened with delight to her mate's "assurances of devoted affection," and was "still coy and undetermined, and seemed fearful of the truth of her lover," and, "virgin-like, resolved to put his sincerity to the test," is lovesome nonsense, as far as regards the feathered tribe; and is a burlesque upon the undeviating tenor of Nature's course. Those who approve of such absurd aberrations from the line of instinct allotted to birds, would do well to confine their studies to the romances on their drawing-room tables. Let us hope that better days are in store for ornithology; and that when the ardent novice shall turn over the pages which may be really intended for his improvement in this fascinating study, he will find their contents in unison with what he will observe afterwards in Nature's boundless range.

If size and beauty give a claim to priority, the ringdove will hold the first place in the scanty catalogue of the wild pigeons of Europe. It stays witl us in Yorkshire the whole of the year; and, in the winter months, it resorts chiefly to the turnip fields for sustenance, where it feeds voraciously on the leaves, and not on the body, of the turnip. The 
leaves are said to impart a rank and disagreeable taste to the flesh of the bird; but this is easily prevented by cutting open the crop, as soon as the pigeon is killed, and discharging the contents. White of Selborne recommends this process. Towards evening the form of the ringdove becomes considerably changed. Having fed on the turnip tops during the course of the day, its crop gets so distended with food, that it gives to the fore part of the pigeon's body a very full appearance; and this is easily discerned as the bird passes over your head to its evening retreat. The contents of the stomach having been digested during the night, we observe that the body has regained its ordinary proportions at the break of day.

There has been a great increase of ringdoves during the winter season, in this part of the country, since the farmers have paid so much attention to the cultivation of turnips. On seeing the congregated numbers of these birds, one is led to imagine that there must be an annual influx of them, at the close of autumn, from some far distant part. As the ringdove is an unprotected bird, and much sought after on account of the delicacy of its flesh, I have strong doubts whether our breeding season can produce a sufficient supply to make up the flocks which are seen here in winter. At all events, in this quarter of Yorkshire, very few young ringdoves are allowed to escape. Farmers and gamekeepers are ever on the look-out to transfer them from the nest to the kitchen. These marauders are so perpetually upon the watch, that it has never yet 
been my lot to find a ringdove's nest in our neighbouring woods with full-fledged young ones in it; although I am continually in the habit of straying into them, and looking for the nests with a careful and unwearied eye. Wherefore, I conclude that our winter flocks receive migratory individuals from distant regions.

The ringdove, by not feeding on insects, renders no service to man while visiting his fields. On the contrary, it is known to injure him considerably in his crop of rising clover. As soon as this plant begins, under the influence of the vernal sun, to expand its leaves, the ringdove attacks the heartshoot with fatal severity; and much address is required on the part of the farmer to scare the birds from their favourite food. Leaving, however, the sons of Ceres to fight their own battles, I will merely add, that this handsome bird is protected here. I love to listen to its soothing murmurs, and take intense pleasure in observing its habits during the breeding season, when it becomes fully as tame as the domestic pigeon. The housekeeper often hints to me that a couple of them would look extremely well on the table; and the farmer calls them devouring vermin. I receive the opinions of these respectable personages with perfect indifference; and I sometimes soothe them by observing that where the ringdove has one friend, it has a thousand enemies, ready to prepare it for the spit, or to prevent for ever its return to the clover field.

The ringdove lays two snow-white eggs on a nest which may be termed a platform of sticks, so spar- 
ingly put together, that the eggs are easily seen through it by an eye habituated to look for them. On inspecting this apparent commencement or remnant of a nest, one is led to surmise, at the first glance, that the young are necessarily exposed to many a cold and bitter blast during the spring of this ever-changing climate. "But God tempers the wind," said Maria, "to the shorn lamb;" and in the case before us, instinct teaches the parent bird to sit upon its offspring for a longer period after they are hatched than, perhaps, any other of the feathered tribe. In the mean time, the droppings of the young, which the old birds of some species carefully convey away, are allowed to remain in the nest of the ringdove. They soon form a kind of plaster strong and scentless. This adds consistency to the nest, producing, at the same time, a defence against the cold. The ornithologist, while going his autumnal beats, in quest of knowledge, on seeing this, will know immediately that the nest has contained young: should this be wanting, he may conclude that the nest has been abandoned at an early period. As he will find but very few nests with this species of plaster in them, he may conclude, to a certainty, that the ringdove has a host of enemies in this country, and that it is seldom fortunate enough to rear its young to that state in which the faculty of flying saves them from destruction.

No bird in the British dominions seems to resort to so many trees and shrubs for the purpose of incubation as the ringdove. Not a tree, from the towering pine to the lowly thorn, ever comes amiss to 
it. There is something, too, peculiarly singular in the locality of some of the nests. While one is seen placed nearly on the topmost branches of the lofty sycamore, another may be found within four feet of the ground, in the humble shelter of the hedge-row bush. Last year, I found a ringdove sitting on one egg, in a magpie's nest of the year gone by ; and I observed another ringdove, rearing two young ones in a spruce fir tree, below that of a magpie, out of which I had taken seven eggs, and substituted five of a jackdaw in their place. It was interesting to see these two species of birds, one so calm and gentle, the other so pert and roguish, thus close to each other, at so critical a juncture. While I was observing them, I felt convinced that there are certain times in which birds are not so bent on plunder as we would fain suppose they are; and, moreover that they can frequent each other's company in perfect peace and quiet. In this instance it appears that instinct showed the ringdove how to preserve her eggs from being plundered by her crafty neighbour, who, according to our own short-sighted view of ornithological economy, would have been apt to make free with them at the earliest call of hunger. The ringdove had settled there with her eyes open to her supposed danger; for the magpie was the first to get possession of the tree.

I had but a faint idea of the habits of the ringdove until I had offered it an undisturbed asylum in this "valley free." Its movements are remarkably periodical. In mild winters, or, more properly speaking, in winters of short continuance, it makes 
its first appearance on the island where my house stands, early in February. This year it came for the first time, on the second of the month, and cooed in full note. From this period, it may be seen here, every day till October, either in the sycamore trees, or in the ivy on the old ruined tower, or on the lawn, picking up the tender sprouts of grass. Provided you approach with "cautious step and slow," you may get within seven yards of different pairs of these birds; and when the window-sash is down, they will come within a few paces of the place where you are standing, and allow you to gaze at them for any length of time. After the first week in October, they take their final leave of my island for the winter; and never, by any chance, pay us even one single solitary visit till February sets in; though they may be seen every day in congregated numbers in other parts of the park, where they roost in the elm and fir trees. During the winter months, they are exceedingly shy and timorous, seeking for safety in lofty flight, the moment they see you approach. They become quite silent towards the last week in October, and their notes are reduced to half their number for some days before they cease to coo entirely. At this period they discontinue those graceful risings and sinkings in the air, in which they appear to so much advantage during the whole of the breeding season.

Thus we have a bird which, during the course of the year, at one time approaches the haunts of man with wonderful assurance, and at another shuns them with a timidity equally astonishing. I speak 
only of its diurnal movements; for, at the close of day, both in winter and in summer, when not molested, this bird will come near to our out-buildings, and seek a roosting-place in the trees which surround them. This peculiarity of the ringdove in approaching so near to our mansions during the day in the breeding season, and then losing all confidence in us, as soon as incubation ceases, is not a mere accidental trait of one or two particular birds, whose usual habits may have been changed, either by want of food, or by protection offered; but it is inherent in the whole species, when the bird is allowed by man to follow Nature's unerring mandates.

I know of no British bird which has the colour of its plumage so constant as is that of the ringdove. I have never yet seen it vary; and the white spot or segment of a circle on the back of its neck, from which it takes its name, is always of the same size.

Ringdoves are exceedingly numerous here during summer; and when winter sets in, many thousands come every evening to take up their quarters for the night. They retire early to roost, and never leave the trees till all the other birds are on the stir.

As yet, all attempts to reclaim this pigeon have been of no avail. I should suppose that it is not in the power of man to make it breed within the walls of a dovecot. For my own part, I am not exactly aware that its reduction to domestication would be productive of much advantage to us. Let others offer it the same protection it enjoys with me, and there would always be an ample supply of ringdoves 
to fill their groves with softest murmurs, and furnish their tables with a delicious repast. Connoisseurs tell us that the flesh of the ringdove, in winter, has the flavour of moor game: I have fed on pigeons in many countries, but cannot say that I ever found them vary in taste from the pigeon which inhabits our common dovecots. Much, perhaps, depends upon the cooking. The culinary art, no doubt, with other important sciences, has derived great benefit from the march of intellect. In London they will serve you up a ram cat for a Martlemas rabbit : and we are told that in Paris a pair of old hunting boots can be stewed down to a very excellent and wholesome soup.

" Nil equidem durare diu sub imagine eâdem

Crediderim."

These cooks will suffer nothing to remain

In pristine flavour, or its shape retain.

NOTES OF A VISIT TO THE HAUNTS OF THE GUILLEMOT, AND FACTS ON ITS HABITS.

The immense range of perpendicular rocks, lashed by old ocean's briny surge, offers a choice and favourable retreat to myriads of wildfowl, from far-famed Flamborough Head to Bempton, and thence to Buckton and Speaton, and onwards to the Bay of Filey.

He who wishes to examine the nidification of these birds ought to be at this part of the sea-coast 
early in the month of May. About five miles from Bridlington Quay is the village of Flamborough, chiefly inhabited by fishermen; and a little farther on is a country inn, called the North Star, which has good accommodation for man and horse; but a lady would feel herself ill at ease in it, on account of the daily visits of the fishermen, those hardy sons of Neptune, who stop at it on their way to the ocean, and again on their return. Here they rendezvous, to fortify their interior with a pint or two of comfort, and to smoke a pipe, by way of compensation for the many buffets which they ever and anon receive in the exercise of their stormy and nocturnal calling.

On the bare ledges of these stupendous cliffs the guillemot lays its egg, which is exposed to the face of heaven, without any nest whatever; but the razorbills and puffins lay theirs in crannies, deep and difficult of access. Here, too, the peregrine falcon breeds, and here the raven rears its young; while the rock pigeon and the starling enter the fissures of the precipice, and proceed with their nidification, far removed from the prying eye of man. The kittiwake makes her nest of dried grass wherever she can find a lodgement, and lays two spotted eggs, very rarely three. The cormorant and shag inhabit that part of the rocks which is opposite to Buckton Hall. You are told that the cormorants had their nests, in former times, near to the Flamborough lighthouse; but now these birds totally abandon the place during the breeding season. The jackdaw is found throughout the whole of this bold and craggy shore; he associates with the seafowl, as though he were quite at home amongst his own inland conge- 
ners. Towards the top of the cliffs, both rabbits and foxes have descended from the table land above them, and managed to find a shelter among the crevices, in places where you would suppose that no four-footed animal would ever dare to venture. A low mound, half earth, half stone, thrown up by the farmers for the protection of their flocks, skirts the winding summit of the precipice. Cattle have been known to surmount this artificial boundary, and lose their lives in the roaring surge below.

This extensive range of rocks, as far as appertains to birds, is not considered private property. Any person who can climb it may carry away what number of eggs he chooses. Still there is a kind of honourable understanding betwixt the different sets of climbers, that they will not trespass over the boundaries which have been marked by mutual consent.

The eggs of the guillemot and razorbills form a considerable article of traffic from old May-day till about the middle of June. Though the eggs of the kittiwake and puffin are of fully as good a flavour, still they are not in such request, on account of their tender shells, which are easily broken in packing, and in transporting from place to place.

The usual process of seeking for the eggs is generally carried on by three men, though two will suffice in case of necessity. Having provided themselves with two ropes of sufficient length and strength, they drive an iron bar into the ground, about 6 in. deep, on the table land at the top of the precipice. To this bar is fastened the thickest of the two ropes, and then it is thrown down the rocks. 
He who is to descend now puts his legs through a pair of hempen braces, which meet round his middle, and there form a waistband. At each end of this waistband is a loophole, through which they reeve the smaller rope. Sometimes an iron hook and eye are used in lieu of this loop. A man now holds the rope firmly in his hand, and gradually lowers his comrade down the precipice. While he is descending he has hold of the other rope, which was fastened to the iron bar; and, with this assistance, he passes from ledge to ledge, and from rock to rock, picking up the eggs of the guillemot, and putting them into two bags, which he had slung across his shoulder ere he commenced his arduous undertaking. When he has filled these bags with eggs, he jerks the rope, and the motion informs his friend at the top that it is now time to draw him up. On coming up again to the place from whence he first set out, all the eggs are taken from the bags, and put into a large basket, prior to their being packed in hampers and carried off in a cart by wholesale dealers, who purchase them from the climbers for sixpence the score. At Bridlington and the neighbouring places the eggs are retailed at a halfpenny a piece.

The rocks are searched for eggs every third day, provided the weather be fair. It requires considerable address on the part of the descending climber to save himself from being hit by fragments of the rock, which are broken off by the rope coming in contact with them. He avoids the danger by moving sidewise when the stone is falling, and by taking care, as he goes down, to clear away with his foot any portion of the rock that seems ready 
to give way. One of the climbers, while he was imparting to me instructions how to act, grinned purposely, and showed his upper jaw. I learned by his story, that, last year, a falling stone had driven two of his front teeth down his throat; while the poor climber, with all his dexterity, was unable to fend off the blow.

As I was lowered down, the grandeur and sublimity of the scene beggared all description, and amply repaid any little unpleasant sensations which arose on the score of danger. The sea was roaring at the base of this stupendous wall of rocks; thousands and tens of thousands of wildfowl were in an instant on the wing: the kittiwakes and jackdaws rose in circling flight; while most of the guillemots, razorbills, and puffins, left the ledges of the rocks, in a straight and downward line, with a peculiarly quick motion of the pinions, till they plunged into the ocean. It was easy to distinguish the puffins from the razorbills in their descent: these, presented a back of a uniformly dark colour : those, had a faint white diagonal line running across the wings. The nests of the kittiwakes were close to each other, on every part of the rocks which was capable of holding them; and they were so numerous, as totally to defy any attempt to count them. On the bare and level ledge of the rocks, often not more than six inches wide, lay the eggs of the guillemots: some were placed parallel with the range of the shelf, others nearly so, and others with their blunt and sharp ends indiscriminately pointing to the sea. By no glutinous matter, nor any foreign body whatever, were they affixed to the rock: bare 
they lay, and unattached, as on the palm of your outstretched hand. You might see nine or ten, or sometimes twelve, old guillemots in a line, so near to each other that their wings seemed to touch those of their neighbours; and when they flew off at your approach, you would see as many eggs as you had counted birds sitting on the ledge.

The eggs vary in size and shape and colour beyond all belief. Some are large, others small some exceedingly sharp at one end, and others nearly rotund. Where one is green, streaked and blotched with black, another has a milk-white ground, blotched and streaked with light brown. Others, again, present a very pale green colour, without any markings at all; while others are of a somewhat darker green, with streaks and blotches of a remarkably faded brown. In a word, nature seems to have introduced such an endless intermixture of white, brown, green, yellow, and black into the shells of the eggs of the guillemots, that it absolutely requires the aid of the well-set pallet of a painter to give an adequate idea of their beautifully blended variety of colouring. The pen has no cliance of success in attempting the description.

The rock-climbers assure you that the guillemot, when undisturbed, never lays more than one egg; but that, if it be taken away, she will lay another; and, if she be plundered of that, she will then produce a third; and so on. If you dissect a guillemot, you will find a knot of eggs within her. The rockclimbers affirm that the bird can retain these eggs, or produce them, according to circumstances. Thus, 
if she be allowed to hatch her first egg, she lays no more for the season; if that egg be lost or taken away, another is laid to supply its place.

The men also assure you that, when the young guillemot gets to a certain size, it manages to climb upon the back of the old bird, which conveys it down to the ocean. Having carried a good telescope with me, through it I saw numbers of young guillemots, diving and sporting on the sea, quite unable to fly; and I observed others on the ledges of the rocks, as I went down among them, in such situations that, had they attempted to fall into the waves beneath, they would have been killed by striking against the projecting points of the intervening sharp and rugged rocks: wherefore I concluded that the information of the rock-climbers was to be depended upon; and I more easily gave credit to it, because I myself have seen an old swan sailing on the water with her young ones upon her back, about a week after they were hatched.

He who rejoices when he sees all nature smiling around him, and who takes an interest in contemplating the birds of heaven as they wing their way before him, will feel sad at heart on learning the unmerited persecution to which these harmless seafowl are exposed. Parties of sportsmen, from all quarters of the kingdom, visit Flamborough and its vicinity during the summer months, and spread sad devastation all around them. No profit attends the carnage; the poor unfortunate birds serve merely as marks to aim at, and they are generally left where they fall. Did these heartless gunmen reflect, 
but for one moment, how many innocent birds their shot destroys; how many fall disabled on the wave, there to linger for hours, perhaps for days, in torture and in anguish; did they but consider how many helpless young ones will never see again their parents coming to the rock with food; they would, methinks, adopt some other plan to try their skill, or cheat the lingering hour.

NOTES OF A VISIT TO THE HAUNTS OF THE CORMORANT, AND FACTS ON ITS HABITS.

THE fabulous story concerning the cormorant made a great impression upon me in early youth; and I well remember with what avidity I first read his true history in the pages of Buffon.

The old fable tells us that the cormorant was once a wool-merchant. He entered into partnership with the bramble and the bat, and they freighted a large vessel with wool. She struck on some rocks, and went to the bottom. This loss caused the firm to become bankrupt. Since that disaster, the bat sculks in his hiding-hole until twilight, in order that he may avoid his creditors: the bramble seizes hold of every passing sheep, to make up his loss by retaining part of its wool; while the cormorant is for ever diving into the waters of the deep, in hopes of discovering whereabouts his foundered vessel lies. So far for the fable, which will always bring 
pleasing recollections into the minds of those who are fond of rural pursuits.

The cormorants often pay me a visit in the winter season; and, could they but perceive that there is safety for them here, and great danger elsewhere, they would remain with me while the water is unfrozen. But they wander, unfortunately, through parts where protection is not afforded them; and, being outlandish birds in the eyes of the neighbouring gamekeepers, they are immediately shot at. Those which find their way here are so unconscious of danger, that, after they have spent a considerable portion of time in diving for fish, they will come and preen their feathers on the terrace which rises from the water, within ten yards of the drawingroom windows.

The cormorant may be justly styled the feathered terror of the finny tribe. His skill in diving is most admirable, and his success beyond belief. You may know him at a distance, among a thousand waterfowl, by his upright neck, by his body being apparently half immersed in the water, and by his being perpetually in motion when not on land. While the ducks and teal and wigeons are stationary on the pool, the cormorant is seen swimming to and fro, "as if in quest of something." First raising his body nearly perpendicular, down he plunges into the deep; and after staying there a considerable time, he is sure to bring up a fish, which he invariably swallows head foremost. Sometimes half an hour elapses before he can manage to accommodate a large eel quietly in his stomach. You see him 
straining violently, with repeated efforts to gulp it ; and when you fancy that the slippery mouthful is successfully disposed of, all on a sudden the eel retrogrades upwards from its dismal sepulchre, struggling violently to escape. The cormorant swallows it again; and up again it comes, and shows its tail a foot or more out of its destroyer's mouth. At length, worn out with ineffectual writhings and slidings, the eel is gulped down into the cormorant's stomach for the last time, there to meet its dreaded and inevitable fate. This gormandising exhibition was witnessed here by several individuals, both ladies and gentlemen, on Nov. 26. 1832, through an excellent eight and twenty guinea telescope; the cormorant being, at that time, not more than a hundred yards distant from the observers. I was of the party.

When I visited Flamborough Head in the first week in June, I was disappointed in not seeing the cormorant there; but I was informed in Bridlington Quay, that this bird was not to be found nearer than the rocks at Buckton; and that it had eggs very late in the season. In consequence of this information, I made a second expedition to the sea coast, and arrived at Bridlington Quay on July 14. 1834 .

About three quarters of a mile from the sea, betwixt Flamborough Head and Filey Bay, stands the once hospitable mansion of Buckton Hall. I say hospitable, because its carved ornaments in stone, its stately appearance, and the excellent manner in which its out-buildings have been constructed, plainly indicate that mirth and revelry must once 
have cheered its walls. But the tide of prosperity has ceased to flow. Something or other seems to have intervened, and turned it down another channel : for now the once well-known Buckton Hall is a neglected mansion; and the stranger, as he passes near it, sees at one glance that it is no longer a place of rendezvous for the great. The present tenant kindly allowed the horse and gig, which I had hired in Bridlington Quay, to be put under cover till I returned from the cliff.

My guide, whose name was Mellor, and who possesses a very accurate knowledge of all the birds in this district, having mustered men and ropes in the village of Buckton, we proceeded across the table land to the Raincliff, which forms a perpendicular wall to the ocean, 140 yards high. Whilst I was descending this precipice, thousands of guillemots and razorbills enlivened the interesting scene. Some were going down to the water, others were ascending from it; while every ledge of the rock, as far as my eye could reach, was literally covered with birds of the same species. The cormorants stayed not to witness my unwelcome descent into their ancient and almost inaccessible settlement. They all took wing, as soon as we reached the edge of the cliff, and went far away to sea. It was a difficult matter to procure their eggs; for the nests were built in places where the rocks overhung them; and it was only by my giving the rope a swinging motion, and then taking advantage of it, as it brought me to the face of the cliff, that $I_{4}$ was enabled to get a footing on the ledges which con- 
tained them. These nests were composed of thick sticks, plants from the rocks, grass, ketlocks which had gone to seed, and a little wool. There were four young birds in one, three eggs in another, two in a third, and one newly laid in a fourth. The shell of the cormorant's eggs is incrusted with a white chalky substance, which is easily scraped off with your penknife, and then you get at the true colour of the shell; the outside of which is of a whitish green, and the inside of a green extremely delicate and beautiful. The egg is oblong in shape, and you find it small for the size of the bird. The four young cormorants were unfledged, and covered with a black down. Their long necks, and long wing-bones, gave them a grotesque, and an almost hideous appearance. They would have been of service to the renowned Callot, when he was making his celebrated sketch of the Temptations of St. Anthony. There came from the nests a fetid smell, so intolerable, that you might have fancied you had got among Virgil's Harpies; or that you were inhaling exhalations from the den of Cacus. Nothing could have been more distressing to your nasal sensibilities.

It is remarkable that on the Raincliff not a kittiwake is seen to alight; and scarcely ever observed to fly close past it. I saw no signs that this bird had ever made its nest here. An attentive naturalist, who would take up his quarters in this neighbourhood, and visit the coast every day during the breeding season, might possibly be able to discover the cause why the kittiwake, which is seen in such 
countless thousands from Flamborough Head to Bempton, should shun the Raincliff, which, apparently, differs in nothing but height from the other parts of this bold and rocky shore.

I am positive that we have not two species of cormorant in Great Britain. The crested cormorant, with a white spot on each thigh, is merely the common cormorant in his nuptial dress. This is not the only bird which becomes highly ornamented during the breeding season. On some future day, when the storms of winter forbid all access to the fields, and condemn me to the dull monotony of life within doors, I may possibly take up the pen, and write down a few remarks upon the change of plumage in birds.

The flesh of the cormorant possesses no flavour that would suit the palate of our modern epicures. Hence it is despised by aldermen, and, of course, never served up at a Lord Mayor of London's feast. On the sea coast, this poor bird is shot at by marksmen through mere wanton pastime; and when he takes a flight inland, he runs great risk of never getting back again to sea; for nobody will befriend him, on account of his well-known inclination to make too free with the contents of well-stored fishponds. Still, for my own part, I love to see him come this way. Stay here, poor wandering mariner, as long as it pleases thee to do so. The sight of thee puts me in mind of the happy hours I spent in reading the Metamorphoses at the Jesuits' College. Well do I remember how beautifully the poet tells thy affecting story, before thou wert reduced to the 
necessity of diving for a livelihood. I do not care if thou takest all the eels in the lake. Thou art welcome to them. I arn well aware that thy stomach requires a frequent-and a large supply. So, pr'ythee, help thyself.

\section{NOTES ON THE HABITS OF THE KING- FISHER.}

"Perque dies placidos hiberno tempore septem
Incubat Halcyone pendentibus aquore nidis."

Ovid. Met., lib. xi.

WHEN the delicious season of spring sets in, I often get up into the topmost branches of a wide-spreading oak; and there, taking the Metamorphoses out of my pocket, I read the sorrows of poor Halcyone. A brook runs close by the tree, and on its bank I have fixed a stump for a resting-place to the kingfisher. On it, this pretty bird will tarry for a while in passing up and down, and then plunge into the stream, and bring out a fish. My elevated station on the oak gives me a fine opportunity of admiring its back, as it darts along beneath me. When the sunbeam is upon it, no words can do justice to the beauty of the glowing azure which attracts the eye.

Modern ornithologists have thought fit to remove the kingfisher from the land birds, and assign it a place amongst the water-fowl. To me the change appears a bad one; and I could wish to see it brought back again to the original situation in which 
our ancestors had placed it; for there seems to be nothing in its external formation which can warrant this arbitrary transposition. The plumage of the kingfisher is precisely that of the land bird, and, of course, some parts of the skin are bare of feathers ; while the whole body is deprived of that thick coat of down so remarkable in those birds which are classed under the denomination of water-fowl. Its feet are not webbed; its breast-bone is formed like that of land birds; and its legs are ill calculated to enable it to walk into the water. Thus we see that it can neither swim with the duck, nor dive with the merganser, nor wade with the heron. Its act of immersion in the water is quite momentary, and bears no similarity to the immersion of those water-fowl which can pursue their prey under the surface, and persevere for a certain length of time, till they lay hold of it. Still the mode of taking its food is similar to that of the gulls, which first see the fish, and then plunge into the deep to obtain it; but this bird differs from the gull in every other habit.

You observe the kingfisher sitting on a rock, or upon the branch of a tree, or hovering over the water; and the moment a fish is seen in the stream below, it drops down upon it like a falling stone. If it miss the mark, which is rarely the case, it comes up again immediately, without further exertion in the water, and then flies off, or occasionally regains its former station in order to make another plunge. As this process of immersion is of very short duration, the bird is enabled to escape with 
impunity from the deep, in which, or on which, were it to remain for a very little time, death would inevitably be its fate.

These undeniable circumstances have induced me to wish for the restoration of the kingfisher to its former situation amongst the land birds; for I feel reluctant to admit that the single act of procuring its food from the water should be thought a sufficient reason for removing it from its old associates, and placing it amongst strangers, with whom it can neither dive nor swim, nor even float with any chance of safety. If the kingfisher is to be considered a water bird merely because it draws its sustenance from the water, then our modern innovators ought to consider the osprey in the same light: and even the barn owl might give them a hint that she feels inclined to seek a new acquaintance; for I myself have seen her plunge into the water, bring out a fish, and convey it to her nest. Indeed, the swallow, with a still better grace, might ask permission to form a new division, distant both from land and water birds, and call it ethereal; because it procures the whole of its sustenance from insects in the circumambient air.

When I remarked above, that the feet of the kingfisher are not webbed, I did not wish it to be understood, that I consider the webbed foot essentially necessary to the act of swimming. The water hen is an expert swimmer, without having the feet webbed; but then, its form and plumage, so different from the form and plumage of land birds, enable it 
to move with swiftness and with safety, either on the water, or under its surface.

There is not much difference in appearance betwixt the adult male and female kingfisher; and their young have the fine azure feathers on the back before they leave the nest. This early metallic brilliancy of plumage seems only to be found in birds of the pie tribe. It obtains in the magpie, the jay, and, most probably, in all the rollers. Whereever it is observed in the young birds, we may be certain that the adult male and female will be nearly alike in colour. We are in great ignorance, and I fear we shall long remain so, concerning colour in the plumage of birds. The adult male and female kingfisher have a very splendid display of fine tints; so have the adult male and female starling; but, though the young of the kingfisher have their bright colours in the first plumage, we find the first plumage of the young starlings pale and dull. I have had an eye to this circumstance for above thirty years, and still I am sorely in want of the schoolmaster.

The old story, that the kingfisher hovers over the water, in order to attract the fish by the brightness of its plumage, is an idle surmise. In the first place, fishes cannot see an object directly above them; and, secondly, if they could see it, there would be nothing brilliant for them to look at in the kingfisher, as all the splendid feathers are upon its upper parts.

A brook runs through this park, and alongside of 
it grows a small oak, part of the roots of which are bare; the earth and gravel having gradually left them, and fallen into the stream below. In the bank where these roots are seen, about six feet from the surface of the water, is a hole in which a pair of kingfishers have had their nest time out of mind. They have afforded me the best possible opportunities of examining their economy; and, from what I have seen, I am perfectly satisfied that this pair of birds, at least, lives entirely upon fish: I have never been able to detect these kingfishers feeding either upon snails, or worms, or insects. They bring up a fish from the water, crosswise in their bills, and then chuck it down their throats head foremost. I do not think that they ever eat a fish piecemeal: and these birds, with me, never utter their ordinary shrill piping succession of notes, except when they are on the wing.

I love to take my stand behind a large tree, and watch the kingfisher as he hovers over the water, and at last plunges into it, with a velocity like that of an arrow from a bow. How we are lost in astonishment when we reflect that instinct forces this little bird to seek its sustenance underneath the water; and that it can emerge from it in perfect safety; though it possesses none of the faculties (save that of plunging) which have been so liberally granted to most other birds which frequent the deep! I sometimes fancy that it is all over with it, when I see it plunge into a pond, which I know to be well stocked with ravenous pike: still it in. 
variably returns uninjured, and prepares to take another dip.

There are people who imagine that the brilliancy of the plumage of birds has some connection with a tropical sun. Here, however, in our own native bird, we have an instance that the glowing sun of the tropics is not required to produce a splendid plumage. The hottest parts of Asia and of Africa do not present us with an azure more rich and lovely than that which adorns the back of this charming little bird; while throughout the whole of America, from Hudson's Bay to Tierra del Fuego, there has not been discovered a kingfisher with colours half so rich or beautiful. Asia, Africa, and America offer to the naturalist a vast abundance of different species of the kingfisher. Europe presents only one; but that one is like a gem of the finest lustre.

I feel sorry to add that our kingfisher is becoming scarcer every year in this part of Yorkshire. The proprietors of museums are always anxious to add it to their collections, and offer a tempting price for it. On the canals, too, it undergoes a continual persecution: not a waterman steers his boat along them, but who has his gun ready to procure the kingfisher. If I may judge from the disappearance of the kite, the raven, and the buzzard from this part of the country, I should say that the day is at no great distance when the kingfisher will be seen no more in this neighbourhood, where once it was so plentiful and its appearance so grateful to every lover of animated nature. Where, in fine, its sin- 
gular mode of procuring food, contrasted with its anatomy, causes astonishment in the beholder, and cannot fail to convince him that modern ornithologists were ignorant of the true nature of the kingfisher when they rashly removed it from its old associates, and assigned it a place amongst strangers, whose formation differs so widely from its own.

\section{NOTES ON THE HABITS OF THE TAWNY OWL.}

OF all our British owls, this is by far the greatest favourite with me, and I take great interest in its preservation.

Whilst temperance societies are rising up in all directions to warn the thirsty sinner that gin and godliness are not in unison, I could wish that some benevolent person would instruct the ignorant on the true nature and habits of many poor dumb animals, which undergo a perpetual persecution, under the erroneous idea that they are inimical to the interests of man. I would willingly go twenty miles on foot, over the flintiest road, to hear some patroness of infant schools tell her little pupils that, nowadays, there are no old women who ride through the air on broomsticks, with a black cat in their laps; that ravens, owls, and magpies have long since dropped all dealing with people in the other world; and that hedgehogs are clearly proved never to have sucked a cow ; though our silly farmers, almost to a man, would fain persuade us that these little harm- 
less creatures are guilty of the preposterous act. Notwithstanding the apprehensions of the dairymaid, I now and then venture to purchase a captive hedgehog, and turn it into the park; there to live and die in peace.

It was but the other day that a neighbouring young lady complained to me of an owl which had been hooting, for three or four successive nights, far too near her bedroom windows; and she wished indeed that it were shot. I startled as she uttered this, for it instantly occurred to me that the bird of which she complained might possibly be one which was bred here last summer; and that its propensity to night-errantry, had brought it into a scrape. So, I tried to persuade her that nothing but sheer curiosity could have induced the owl to take the undue liberty of peeping in at her window; and I was sure that it could have seen nothing there to displease it.

I have never heard an owl, either in Europe or in America, that utters sounds so nearly resembling the human voice as those which our tawny owl sends forth. Here, where all is still, and every thing to be found that is inviting to the feathered race, this bird will hoot at intervals throughout the day, both in cloudy and in sunny weather. Were you to pronounce the letter $\mathrm{O}$ in a loud and very clear tone of voice, and then, after a short pause, repeat the same letter in a drawling, tremulous accent, you would have a tolerably just idea of the hooting of the tawny owl. It will sometimes produce a sharp cry, which sounds not unlike the word quo-ah : both male and female utter this cry. 
Though the tawny owl generally takes up its abode in dark and gloomy woods, still it occasionally settles very near the habitation of man. In a hollow sycamore, within a dozen yards of this house, there had been the nest of a tawny owl, time out of mind. Here the birds would have remained to this day, had not a colony of jackdaws, which I had encouraged, by hanging up wooden boxes for them in the next tree, actually driven the owls away, in order that they might get possession of the hole. Before this misfortune befel them, a servant once robbed their nest, and placed the young ones in a willow cage, not far from the hollow tree. The parent birds brought food for their captive offspring; but, not being able to get it through the bars of the cage, they left it on the ground on the outside. This food consisted of mice, rats, small birds, and fish, which I myself saw and examined. At the present time, I have a tawny owl, sitting on four eggs, in a large ash tree, close to a much-frequented summer-house. The male stays in a spruce fir tree, and hoots occasionally throughout the day. I have found, by dissecting the ejected bolus of this species, that is feeds copiously upon different sorts of beetles.

Were I just now requested to find a hollow tree in the woods of the neighbourhood, I should say that it were useless to go in quest of one; so eager have the proprietors been to put into their pockets the value of every tree which was not "making money," according to the cant phrase of modern wood-valuers. No bird has felt this felling of ancient 
timber more than the tawny owl. To the extreme scarcity of breeding-holes, and to the destructive measures of the gamekeepers, I attribute the great rarity of this bird in our own immediate neighbourhood: add to this, that it sometimes rests on the ground, under covert of a bush, where it is flushed and killed by sportsmen while in pursuit of woodcocks. Were it not for my park, I believe that the tawny owl would be extinct in this part of Yorkshire. Some ten years ago, it was so scarce, that I seldom heard its voice. Once or so, in the winter, I could catch the hooting of a solitary owl as I was after the midnight poachers; but that was all: and, then, whole weeks would elapse before I could hear the pleasing notes again. At present, however, this favourite warbler is on the increase.

He who befriends the tawny owl, and loves to have it near his mansion, may easily make a habitation for it, provided there be a wood at hand, with full-grown ash trees in it. But, no wood, no tawny owl; Point d'argent, point de Suisse, as the saying has it. On examining his ash timber, he will occasionally find a tree with a particular fungus on it; yellow when growing, and black when ripe. But more of this, perhaps, another time, should I ever offer to the public a short paper on the cause and prevention of dry rot: a misnomer, by the way. When this fungus falls to the ground, after the rains of winter have set in, the bark on which it has grown shows such faint traces of a change, that an eye not accustomed to look for these things would scarcely notice the distempered part. By means, 
however, of a hammer and a chisel applied to the spot, you are soon let into the secret: and you find the wood, in the quarter where the fungus appeared, of a texture soft and altered, and somewhat approaching to that of cork. Here, then, you can readily form an excavation large enough to contain a pair of tawny owls.

In the year 1831, I pointed out to Mr. Ord (the elegant and scientific biographer of poor Wilson) just such an ash tree as that which I have described. It was above $2 \mathrm{ft}$. in diameter, and there was a fungus on the western side of it. After I had excavated nearly half way through the tree, I found a portion of the wood more tainted than the rest: so, putting a longer handle into the socket of the chisel, I worked in the direction which it took; until, most unexpectedly, I came to the nest of a titmouse. The bird, like the Portuguese at Mindanao, liad evidently taken possession of the tenement through an aperture from the eastward, now closed up with living bark; while I, like the Spaniards, had arrived at the same place, by pursuing a course from the westward. If I might juclge by the solid appearance of the bark, I should say that, some fifty or sixty years ago, a branch must have been blown off from this eastern side of the bole; and there the rain had found an entrance, and had gradually formed a cavity. The titmouse, judging it a convenient place, had chosen it for her nidification; and, probably, had resorted to it every year, until the growing wood at the mouth of the orifice had contracted the entrance, and, at last, closed it up for ever : leaving 
the nest hermetically sealed in the bole of the tree. A thousand people might gaze on this tree, in passing by, and still not see a blemish. I myself can just perceive it, by means of a few concentrated lines still visible on the bark; but, had not the discovery of the nest drawn my attention to the place, I should never have perceived that the eastern part of the tree had formerly received an injury. Mr. Ord was enraptured at the exposition of the ornithological treasure; and noted down in his pocketbook every thing worthy of record. The tree still stands: and long may it stand, to gratify the curiosity of naturalists. Last year, a pair of barn owls reared their young in it: and, just now, there are eggs in the same place. I made another excavation, in an ash tree about two hundred yards from this; and, last summer, it gave me an increase of three tawny owls. Throughout the winter, I could, at any time, find them reposing in some neighbouring fir trees.

The tawny owl generally lays four snow-white eggs in the same hole which it had chosen for its winter quarters. I am satisfied in my own mind, that no owl in the world ever gathers materials to form the lining of its nest. Indeed, there is no necessity whatever for it to take that trouble; nature makes a sufficient provision for the lining of the hole to which the owl resorts, long before the breeding-time sets in. Every species of this bird ejects from the stomach all the indigestible parts of their food, in the shape of a dark-coloured oblong bolus; which, when dried, is soon reduced to frag- 
ments by the superincumbent body of the bird. On this the female lays her eggs; nor could she well procure a better or a softer substance for them.

Trifling as an attention to the featliered tribe may seem, still it has its sweets for those who love to lead a rural life. I generally observe that visiters who come here are always anxious to have a sight of the birds which take up their abode in this sequestered valley; and they listen with evident signs of pleasure to the cries of the nocturnal wanderers of the air. It is not above a week ago that I heard the heron screaming, the wigeon whistling, the barn owl screeching, and the tawny owl hooting, in rapid succession. The moon was playing on the water at the time, and the air was nearly as warm as summer. I thought of times long past and gone, when I was enjoying nature's richest scenery in the interminable forests of Guiana.

NOTES ON THE HABITS OF THE WIGEON.

From the month of May to that of October, we know nothing of the haunts and economy of this cheerful and familiar stranger; for he always takes his leave of us in spring; at which time he is supposed to proceed to distant regions of the north, where ornithologists have never yet dared to venture. 
I am satisfied in my own mind, that the wigeon does not stay here to breed. All my endeavours to find its nest have hitherto been ineffectual; nor can I recollect to have met with one well authenticated account of the wigeon's eggs having ever been found in England.

Formerly, I used to consider the wigeon as one of those migratory birds of which little could ever be known, as it merely came here to spend the winter months amongst us, in order to avoid the dismal tempests which were raging in its own native land. Under this erroneous impression, I always availed myself of every opportunity to get a shot at the wigeons. Of course, this made them exceedingly shy and wary; for persecution soon shows to birds the danger of placing themselves within the reach of man. Hence their visits here were few and transitory; and sometimes weeks elapsed without my seeing a single wigeon on the water.

Since I have shut the temple of Janus, and proclaimed undisturbed repose to those of the feathered race which come to seek for shelter here, the wigeons are in great abundance; and, from the time of their arrival to the period of their departure, they may be found here every day, whether in a frosty, a snowy, or an open season. A stranger, on observing them, would hardly suppose that they are wild fowl; for he will often see nearly one hundred of them congregating with the tame ducks, not sixty yards from the kitchen windows. Protection has restored to them their innate familiarity; and now 
I am enabled to say something on certain parts of their economy, which our ornithological writers seem never to have noticed.

The wigeon is a much more familiar bird than either the pochard or the teal. While these congregate on the water, beyond the reach of man, the wigeon appears to have divested itself of the timidity observable in all other species of wild fowl, and approaches very near to our habitations. A considerable time elapsed before I was enabled to account satisfactorily for the wigeon's remaining here during the night; a circumstance directly at variance with the habits of its congeners, which, to a bird, pass the night away from the place where they have been staying during the day. But, upon paying a much closer attention to it than I had formerly been accustomed to do, I observed that it differed from them all, both in the nature of its food, and in the time of procuring it. The mallard, the pochard, and the teal obtain nearly the whole of their nourishment during the night. On the contrary, the wigeon procures its food in the day time, and that food is grass. He who has an opportunity of watching the wigeon when it is undisturbed, and allowed to follow the bent of its own inclinations, will find that, while the mallard, the pochard, and the teal are sporting on the water, or reposing on the bank at their ease, it is devouring with avidity that same kind of short grass, on which the goose is known to feed. Hence, though many flocks of wigeons accompany the other water-fowl in their nocturnal wanderings, still numbers of them pass the whole of the night here; and 
this I know to be a fact, by their singular whistling noise, which is heard at all hours.

On January 26. 1832, for the first time, I satisfied myself beyond all doubt of what I had long suspected, namely, that wigeons feed upon grass, exactly after the manner of geese. A flock of them was then feeding opposite the windows. I took the large telescope, and distinctly saw them feeding voraciously on the green short blades of grass. Whilst I am writing this (January 12. 1835) the ground is covered with snow, except under some large elm trees; and at the root of these there are, just now, above one hundred wigeons and thirty coots, all feeding on the grass which is not concealed by the snow.

In other places, where persecution is the wigeon's lot, no doubt it will be very shy in frequenting pastures during the day; and, of course, it will be compelled, contrary to its natural habits, to seek for food throughout the night, in company with its congeners.

As the ordinary food of the wigeons is evidently grass, perhaps there may not be a sufficient supply of it in those high northern regions, whither the water-fowl are supposed to repair when they leave us in spring. Should this conjecture prove well founded, we can account for the wigeon remaining with us till the beginning of May, at which period all the migratory water birds (saving a few teal, which are known to breed in England) must be busily employed, far away from us, in the essential work of incubation. 
Though we are quite ignorant of the manner and place in which the wigeon makes its nest, and of the number and colour of its eggs, still we are in possession of a clew to lead us to the fact, that it hatches its young long after its congeners the mallards have hatched theirs. The mallards return here, in full plumage, early in the month of October; but the wigeons are observed to be in their mottled plumage as late as the end of November. Again, as the old male wigeon returns to these latitudes in mottled plumage, we may safely infer that he undergoes the same process of a double moulting as the mallard; on which, perhaps, a paper hereafter.

I offer to ornithologists, these few observations and speculations on the economy of the wigeon, to be approved of, or reproved, or improved, just as they may think fit. Every disquisition, be it ever so short, will help a little to put the science of ornithology upon a somewhat better footing than that on which it stands at present. From reviews, which I have lately read with more than ordinary attention; and from representations of birds, which I have lately examined very closely, I pronounce ornithology to be at least half a century behind the other sciences. I say nothing of the stuffing of birds for cabinets of natural history. Were I to touch upon the mode now in general use, I should prove it to be a total failure, devoid of every scientific principle; a mode that can never, by any chance, restore the true form and features of birds.

But to return to the wigeon. I will just add, in 
conclusion, that I penned down the remarks on its habits, after many very close and often repeated inspections of the bird, during its winter residence amongst us. I fear, however, that we must be contented to remain in absolute ignorance of many important parts of its history, until some bold and hardy naturalist shall penetrate into those distant regions of the north, where this pretty bird, in company with myriads of other wild fowl, is supposed to pass the summer months in undisturbed security.

\section{NOTES ON THE HABITS OF THE HERON.}

OF all the large wild birds which formerly were so common in this part of Yorkshire, the heron alone can now be seen. The kite, the buzzard, and the raven have been exterminated long ago by our merciless gamekeepers. Ignorant of the real habits of birds, and ever bent on slaughter, these men exercise their baneful calling with a severity almost past belief. No sooner have they received from government their shooting license, than out they go with the gun, and, under one pretext or other, they kill almost every bird which comes in their way. Our game laws are at the bottom of all this mischief.

_ "Illis, non sævior ulla

Pestis, et ira Deûm, Stygiis sese extulit undis." 
Than these, a greater pest our statesmen never

Sent from their old burnt house near London river.

Kites were frequent here in the days of my father; but I, myself, have never seen one near the place. In 1813, I had my last sight of the buzzard. It used to repair to the storm-blasted top of an ancient oak which grows near the water's edge; and many and many a time again have I gone that way, on purpose to get a view of it. In the spring of that year, it went away to return no more; and, about the same period, our last raven was shot on its nest by a neighbouring gentleman.

In vain I now look for any of these interesting birds in our surrounding woods. They have been declared great destroyers of game; they have, in consequence, suffered persecution; and like the family of poor Charley Stuart (God rest his soul!), they no longer appear on their own native land, in this district, where once they graced our rural scenery.

The heron, however, notwithstanding this hostile feeling, has managed to survive its less fortunate neighbours. Always on the look-out, it sees in time the threatened danger, and generally contrives to avoid it; for persecution has rendered it fully as shy and wary as the pie itself. Formerly, in this country, the heron was a protected bird, in order that it might afford pastime to the great; but, nowadays (as little or nothing remains of falconry, except a title which introduces the finger and thumb of the bearer into the public purse), the heron is abandoned to its fate ; and the fishpond owners may way lay it with impunity, whenever an opportunity offers. 
I attribute the bad character which the heron has with us, for destroying fish, more to erroneous ideas, than to any well authenticated proofs that it commits extensive depredations on our store-ponds. Under this impression, which certainly has not hitherto been to my disadvantage, I encourage this poor persecuted wader to come and take shelter here ; and I am glad to see it build its nest in the trees which overhang the water, though carp, and tench, and many other sorts of fish, are there in abundance. Close attention to its habits has convinced me that I have not done wrongly. Let us bear in mind that the heron can neither swim nor dive; wherefore the range of its depredations on the finny tribe must necessarily be very circumscribed. In the shallow water only can it surprise the fish; and, even there, when we see it standing motionless, and suppose it to be intent on struking some delicious perch or passing tench, it is just as likely that it has waded into the pond to have a better opportunity of transfixing a water-rat lurking at the mouth of its hole, or of gobbling down some unfortunate frog which has taken refuge on the rush-grown margin of the pool. The water-rat may appear a large morsel to be swallowed whole; but so great are the expansive powers of the heron's throat, that it can gulp down one of these animals without much apparent difficulty. As the ordinary food of this bird consists of reptiles, quadrupeds, and fish, and as the herons can only catch the fish when they come into shallow water, I think we may fairly consider this wader as not very 
injurious to our property; especially when we reflect for a moment on the prodigious fecundity of fish. Take the roach for example. It swarms here in multitudes sufficient to satisfy the cravings of every heron and every cormorant in Europe.

Should the lords of the adjacent fishponds ever read the contents of this paper, I would fain hope that their animosity against the heron will be diminished, and that they will order their gamekeepers to spare in future a bird which every body loves to see. Indeed, what can be more interesting to the ornithologist than to have it in his power to watch a dozen of these birds standing motionless on one leg, for hours together, upon some leafless branch of a tree ; or to see them flapping their way over his head, on wings much more arched than those of any other bird that cleaves the liquid void.

The heron is gregarious during the breeding season; though sometimes a solitary nest may be found miles away from the place of general rendezvous. At other times of the year, the society seems to be dissolved; and the bird is seldom seen in this part of the country in parties of more than ten or twelve together. The nest appears like that of the rook, only often much larger; and it may be found on the willow, the oak, the fir, and the sycamore, and probably on many other kinds of trees, when they are in a place which affords security, and invites the heron to incubation. By the time that the young are ready to fly, the outside of the nest, and part of the tree which bears it, appear to the observer below as 
though they had been completely whitewashed: but the rains of winter cleanse the nest anew, and restore the branches to their former colour.

There is an old and vulgar notion, still current here, that, when the heron is sitting on her eggs, her legs appear hanging down on the outside of the nest. Probably the length of the heron's legs has given rise to this absurdity. A very slight inspection of the formation of the bird would suffice to convince the observer of his error. The thighs of all known birds are of a length exactly proportioned to that of the legs; wherefore, when a bird wishes to place itself in a sitting position, the bending of the knee causes the leg to recede sufficiently towards the tail to allow the feet to come to the centre of the body. This being the case, the heron places its legs in the nest with as much facility and ease as all other birds place theirs. Indeed, it cannot possibly perform its incubation with its legs outside of the nest; and the admirable provision of nature, in always giving to birds a due proportional length in their legs and thighs, saves the heron from the necessity of attempting to place itself in such an unsightly posture. In fact, the formation of the parts would not admit of it; and were a bird, by any chance, to put itself in a position by which the legs would appear on the outside of the nest, we may rest assured that both great pain and great inconvenience would ensue, and soon force it to resume the common process of incubation. The thighs, by being stretched asunder, would be thrown out of their ordinary bearings ; and 
the feathers, by coming in contact with the outer materials of which the nest is formed, would be forced into a direction quite opposite to that which they have received from the hand of nature. Hence we may safely conclude that neither the herons, nor any other birds of the creation, ever perform their incubation with their legs on the outside of the nest.

In the day-time this bird seldom exhibits any very extraordinary activity. Altheugh it will fly from place to place at intervals, still it seems to pass the greater part of the time betwixt sunrise and sunset quietly on the bank of a stream, or on the branch of a tree, often with one leg drawn up under the body in a most picturesque manner. But, as soon as the shades of night set in, the heron becomes as anxious and impatient as a London alderman half an hour before the Lord Mayor's festive dinner. It walks up and down the bank, or moves from branch to branch with extraordinary activity, every now and then stretching out its wings, and giving us to understand, by various gesticulations, that it is about to commence its nocturnal peregrinations in quest of food. One loud and harsh cry, often repeated, now informs you that the heron is on wing, wending its way to some distant river, swamp, or creek. I suspect that this cry is never uttered but when the bird is flying.

Formerly we had a range of fishponds here, one above the other, covering a space of about three acres of ground. Close by them ran a brook, from 
which the water-rats made regular passages through the intervening bank into the ponds. These vermin were engaged in never-ceasing mischief. No sooner was one hole repaired, than another was made; so that we had the mortification to see the ponds generally eight or ten inches below water-mark. This encouraged the growth of weeds to a most incommodious extent, which at last put an end to all pleasure in fishing. Finding that "the green mantle from the standing pool" was neither useful nor pleasant, I ordered the ponds to be drained, and a plantation to be made in the space of ground which they had occupied. Had I known as much then as I know now of the valuable services of the heron, and had there been a good heronry near the place, I should not have made the change. The draining of the ponds did not seem to lessen the number of rats in the brook; but, soon after the herons had settled here to breed, the rats became extremely scarce; and now I rarely see one in the place where formerly I could observe numbers sitting on the stones at the mouth of their holes, as soon as the sun had gone down below the horizon. I often watch the herons on the banks of some other storeponds with feelings of delight; and nothing would grieve me more than to see the lives of these valuable and ornamental birds sacrificed to the whims and caprice of man.

I know, and freely avow, that the herons will catch fish (especially eels), whenever those fish frequent the shallow water; still these birds make 
ample amends for their little depredations, by preventing the increase of rats and frogs. Little, indeed, must be those depredations: for fishermen are allowed to come here, during the summer, in unrestricted numbers, and the herons have their nests in the trees which hang over the water; still there is always a most plentiful supply of fish.

If country gentlemen would grant protection to the heron, it would be to us, in some sort, what the stork formerly was, and now is, to our Continental neighbours; namely, an ornamental and a useful bird. Though it certainly would not be so domestic as the stork, still the protection afforded it would tend considerably to change its present habits. Nothing but the roar of guns, the prejudices of pond-owners, and the barbarity of gamekeepers, has rendered the heron a shy, degraded, and devoted bird.

\section{THE DIPPER.}

"Mr. Waterton will not, I believe, allow that birds ever oil their feathers; but I would wish to ask of him, how he accounts for the fact that, while the feathers of a thrush or robin, if they have only fallen into the water for a few minutes, become totally spoiled, as far as the purposes of stuffing are concerned, those of the dipper may remain half an hour or more in the water without receiving any damage?" (Rev. F. O. Morris, in Mag. Nat. Hist., vol. viii. p. 375.)

I cannot account for the fact stated by the Rev. Mr. Morris. If he infers that birds oil their plumage 
from the fact that the feathers of the dipper " may remain half an hour or more in the water without receiving damage," he nullifies his inference, by adducing a subsequent fact, that the feathers of a robin or a thrush, "if they have only fallen into the water for a few minutes, become totally spoiled, as far as the purposes of stuffing are concerned " for the robin and the thrush have the oil-gland as completely developed, and as perfect in every point of view, as that of the dipper. If, then, the feathers of the dipper are preserved from injury in the water by the contents of the oil-gland, surely, by a parity of reasoning, those of the robin and the thrush ought to be equally preserved. But the Rev. Mr. Morris informs us that the feathers of the robin and the thrush become totally spoiled, as far as the purposes of stuffing are concerned, if they have only fallen into the water for a few minutes. This I consider tantamount to an avowal, on the part of the reverend ornithologist, that the robin and the thrush do not lubricate their feathers. So much for the oil-gland, and its supposed uses.

I will now take the liberty of assuring the Rev. Mr. Morris, that the feathers of the robin and the thrush do not become totally spoiled, as far as the purposes of stuffing are concerned, by immersion in the water; on the contrary, their plumage is improved by it. Merses profundo, pulchrior evenit. I will engage to steep a robin and a thrush for a whole day in a basin of water, and make better specimens of them than if I had stuffed them before they had undergone the immersion. 
A concluding word on the remark, that "the habit of the dipper walking underneath the water, is too well known and authenticated to need any additional information from me" [that is, from Mr. Morris]. I am not a convert to the doctrine of a subaquatic promenade: first, because I know that the bodies of all birds float on the surface of the water; secondly, because I am convinced that birds are obliged to make great exertions with their wings; and feet in order to be able to reach the bottom thirdly, because I am satisfied that, as soon as they have arrived at the bottom of the water, the force which enabled them to descend to it ceases to act. Hence I infer that the body of a bird, impelled to the bottom by the aid of the feet and wings, must rise again when deprived of that aid. I can easily conceive, however, that the dipper, by the use of its legs and wings, may manage to keep sufficiently near the bottom to be enabled to turn over the pebbles with its bill in quest of food; because, in this position, the legs and wings would have power to act, and they would tend to counteract the rising motion of the body. I maintain positively, that a bird cannot, by any chance, walk on the ground under water. The moment it attempted to do so, the legs and wings, by the altered position of the body, would be deprived of all depressing power; and the body itself would be raised up towards the surface by the fluid in which it is immersed. This would put an effectual stop to all proposed perambulations at the bottom of the stream. This is only theory, and theory may err. I often used to watch 
the dipper, when in Northumberland; but I own that I never had courage to follow it to the realms below, in order to have a clear and distinct view of its proceedings. I wish that old Nicolas Pescé were alive in these days. I would engage him to put this very important ornithological question at rest for ever. Old Nicolas was quite at home under water. His toes and fingers (credat Judaus) were said to be webbed; and he could take in at one gulp as much breath as would serve him for a whole day. They tell us, he would often spend five days together in the midst of the waves, and live on the fish which he caught. The roaring gulfs among the Lipari Islands were a kind of Hyde Park promenade to him. Nick would resort to them whenever he felt inclined to take an airing, either for his amusement, or for the benefit of his health.

ON THE HABITS OF THE WATER OUZEL, WITH A FEW REMARKS ON THE OIL GLANDS IN BIRDS.

THE water ouzel is sometimes known by the name of the dipper in England, and by that of merle d'eau in France, and is pronounced to be a water-fowl by Buffon. Indeed, as the count affected to believe the strange story of Monsieur Herbert, he might have called it the water bird par excellence; it being 
supposed to possess a subaquatic faculty, not granted to any other bird in the creation.

The water ouzel is found in hilly countries, where rapid rivulets wind their way through an abrupt and rocky bed. Here, it is never seen; but I have had opportunities of paying attention to its habits in the county of Northumberland, where it frequents the borders of transparent streams, which meander through the moors. There, you will find its nest, in favoured localities, overhanging the brook; while, ever and anon, you see the bird itself go under water, in quest of its wonted food.

This is the bird which has given rise to so much controversy. This is the bird whose supposed subaquatic pranks have set the laws of gravity at defiance, by breaking through the general mandate which has ordained that things lighter than water shall rise towards its surface, and that things which are heavier shall sink beneath it. If the water ouzel can walk on the ground at the bottom of the water, then, indeed, we may exclaim with the poet,

" Omnia Naturæ præpostera legibus ibunt,

Parsque suum mundi nulla tenebit iter."

All Nature's laws will tumble in decay, And e'en the world itself will lose its way.

How comes it that writers concede to the dipper alone the privilege of turning nature's mandates topsyturvy? Why do not they tell us, that the grebes, the coots, and the water hens (which last have cloven feet) can walk at the bottom of streams? The question is easily answered. The birds just 
enumerated frequent waters which are generally either too deep, or too muddy, to allow the eye of man to follow them to any great distance in their descent. Add to this, that these birds are much more shy and wary than the water ouzel, and they contrive to keep out of the reach of observation; thus depriving naturalists of the opportunity of a close investigation of their subaquatic habits. But here, where the grebe, the coot, and the water hen come close to the terrace which rises from the lake, I can steal upon them, and see them dive whilst I am standing above them; and I can affirm that they never do walk on the bottom. Now, the rivulets frequented by the water ouzel afford numberless opportunities to the observer who wishes to watch the motions of this bird. He has only to conceal himself behind some rock which rises from the stream, or to show himself suddenly on the bank of the brook where the water ouzel is found, and he will see the little bird go under water, and he will be able to trace its downward process. He then fancies that he sees it walk on the ground, when, in fact, it does no such thing; the observer's own eyes, in this instance, giving him false information.

Monsieur Herbert was the first man on record, according to Buffon, who persuaded himself that the water ouzel actually performed the impossible feat of walking on the ground at the bottom of streams; and he communicated his supposed discovery to the count. The water ouzel appeared, says Monsieur Herbert, "enveloped with air, which gave it a bril- 
liant surface." Now, we all know that this garment of air would have added considerably to the natural levity of the bird. It ought to have had a roquelaure of lead, not of air. "It seemed to quiver," continues Monsieur Herbert. There would have appeared no quivering, had the bird been really walking on terra firma.

If the water ouzel, which is specifically lighter than water, can manage, by some inherent power, to walk on the ground at the bottom of a rivulet; then there is great reason to hope that we, who are heavier than air, may, any day, rise up into it, unassisted by artificial apparatus, such as wings, gas, steam, or broom-staff.

\section{NOTES ON THE HABITS OF THE MALLARD.}

Thrs bird yields to none of our wild water-fowl in loveliness of plumage, while it far surpasses most of them in the excellent flavour of its flesh. Having been completely subjugated by man, it can now be obtained either in its enlarged dimensions, acquired by superabundance of food picked up at the barndoor of its owner, or in its original small and compact form, on which a precarious subsistence in the field of freedom has hitherto worked no visible change.

There cannot be a doubt that the wild duck and the domestic duck have had one and the same origin. They are still intimate; for they breed together, 
and flock together, and are both subject to the double annual moulting; of which more anon. The domesticated duck only loses its inclination for flying, when it is bred and reared far from any large sheet of water; but where an extent of water is at hand, this bird will be observed to assume more brisk and active habits. It will indulge in long and lofty flights, and frequently take off with the congregated wild-fowl in their nocturnal excursions.

I have the finest possible opportunity of looking into the habits of the mallard at any hour of the day, from the rising to the setting sun; for here this bird, and large flocks of its congeners, are perpetual visitors during the winter months. They fear no danger; and they seem to know that in this populous neighbourhood there is one retreat left to which they can retire, and in which they can find a shelter from the persecutions which are poured down so thick upon them in other places, by man, their ever watchful and insatiate pursuer.

Some six years ago, I put a number of wild ducks' eggs to be hatched by a domestic duck. The produce of these eggs having intermixed with the common barn-door breed of ducks, there has been produced by this union such an endless variety of colouring, that it is now impossible to trace the identical origin of the birds with any degree of certainty. Half wild, half tame, they will come to the windows to be fed; but still they have a wariness about them quite remarkable; and they will often startle and take wing at very trivial causes of alarm. In this group the naturalist may see the milk-white 
duck, and the duck in the real wild plumage; and others of every intermediate colour; now sporting and diving before him, now retiring to the stranger flocks at a distance, and now rising with them in the air at the close of day, to pursue in congregated numbers their journey through the heavens, to those favourite places which afford them a regular supply of food.

In 1827, two males and three females made their appearance here, and took up their permanent quarters with the domestic ducks. They resembled the original wild breed in every thing except in size. You could barely perceive that they were a trifle larger, and that was all. Hence I conclude that there must have been a shade of the reclaimed duck in their parentage. Though shy at first, in time they became surprisingly tame. One of the ducks singled out the cook as an object worthy of its attention, and would steal into the kitchen whenever an opportunity offered. The number is now reduced to one, the other four having disappeared at intervals. Fearing that this last remaining bird might give me " the slip for ever," I have taken the precaution to pinion him. The curtailing of his flight will probably be the means of prolonging his existence; for I always conjectured that his companions had been surprised and killed in their aberrations down the neighbouring brooks, where protection was not extended to them.

The wild ducks which frequent this place may be observed to catch insects on the water in the daytime : but they do not, in general, rove on land in 
quest of food, though once or twice, in moist and heavy weather, I have seen them waddle through the pasture; but I marked the fact down, as one of rare occurrence. When undisturbed, they are seen to pass much of their time asleep on the ground. At intervals they will take to the water; and while some float on it, with the head reclined on the shoulder, others will sport and dive into the deep, and then return to land, and there arrange and preen their feathers, though not with oil from the gland on the rump, as is generally supposed. At the close of day they become exceedingly vociferous, the voice of the female being much louder and more frequent than that of the male; a circumstance too notorious in the human species. After this uproar of tongues has continued for a certain time, they rise on rapid wing in detached flocks, and, to a bird, they go away for the night. At early dawn they return in companies, consisting of fifteen or twenty birds, and stay here, to pass the day in peace and quiet. When the water is frozen over, they sometimes huddle together on the ice, and at other times collect in one large flock in the adjacent pasture. Every now and then a peregrine falcon makes his appearance, and perches on a neighbouring sycamore tree. We know of his approach by the singular agitation which takes place amongst the ducks ; they shake their wings with a tremulous noise, and get into a compact group. After this they all rise in the air; and then you may see the falcon dash at an outside duck with an almost inconceivable velocity.

o 4 
"Ocior cervis, et agente nimbos

Ocior Euro."

One morning he was observed to pursue a teal, which only just escaped destruction by alighting on a pond, within a few yards of the place where some labourers were at work.

I should think that the old birds remain in pairs through the entire year; and that the young ones, which have been hatched in the preceding spring, choose their mates long before they depart for the arctic regions in the following year. I have a favourite hollow oak tree on a steep hill, into which I can retire to watch the movements of the pretty visitors. From this I can often see a male and female on the water beneath me, nodding and bowing to each other with as much ceremony as though they were swimming a minuet, if I may use the expression. Hence I conclude that there is mutual love in the exhibition, and that a union is formed.

When these large flocks of wildfowl take their departure in spring for the distant regions of the north, about a dozen pairs of mallards remain here to breed. Sometimes you may find a solitary nest of these birds near the water's edge, or a few yards from it, on a sloping bank thickly clothed with underwood: but, in general, they seem to prefer the recesses of a distant wood for the purposes of their incubation; though we have had an instance of one building its nest in a tree, and of another which hatched its young on an old ruin. Last year a domesticated wild duck had a brood of ten young ones in the month of May; and on the 27 th day of 
October the same bird brought out a second brood of eleven. In an evil hour they strayed too far from the water. A tame raven met them on their travels, and killed every bird.

At the close of the breeding season, the drake undergoes a very remarkable change of plumage: on viewing it, all speculation on the part of the ornithologist is utterly confounded; for there is not the smallest clue afforded him, by which he may be enabled to trace out the cause of the strange phenomenon. To Him alone, who has ordered the ostrich to remain on the earth, and allowed the bat to range through the ethereal vault of heaven, is known why the drake, for a very short period of the year, should be so completely clothed in the raiment of the female, that it requires a keen and penetrating eye to distinguish the one from the other. About the 24th of May, the breast and back of the drake exhibit the first appearance of a change of colour. In a few days after this, the curled feathers above the tail drop out, and gray feathers begin to appear amongst the lovely green plumage which surrounds the eyes. Every succeeding day now brings marks of rapid change. By the $23 \mathrm{~d}$ of June scarcely one single green feather is to be seen on the head and neck of the bird. By the 6th of July every feather of the former brilliant plumage has made its disappearance, and the male has received a garb like that of the female, though of a somewhat darker tint. In the early part of August this new plumage begins to change gradually, and by the 10th of October the drake will appear again in all his rich magnifi- 
cence of dress; than which scarcely any thing throughout the whole wild field of nature can be seen more lovely, or better arranged to charm the eye of man. This description of the change of plumage in the mallard has been penned down with great care. I enclosed two male birds in a coop, from the middle of May to the middle of October, and saw them every day during the whole of their captivity. Perhaps the moulting in other individuals may vary a trifle with regard to time. Thus we may say that once every year, for a very short period, the drake goes, as it were, into an eclipse, so that, from the early part of the month of July, to about the first week in August, neither in the poultry-yards of civilised man, nor through the vast expanse of Nature's wildest range, can there be found a drake in that plumage which, at all other seasons of the year, is so remarkably splendid and diversified.

Though I dislike the cold and dreary months of winter as much as any man can well dislike them, still I always feel sorry when the returning sun prepares the way for the wildfowl to commence their annual migratory journey into the unknown regions of the north. Their flights through the heavens, and their sportings on the pool, never fail to impart both pleasure and instruction to me. When the time of their departure comes, I bid my charming harmless company farewell, and from my heart I wish them a safe return. 
ON SNAKES, THEIR FANGS, AND THEIR MODE OF PROCURING FOOD.

Mr. TAYLoR, in his paper which appeared in The Magazine of Natural History, vol. viii. p. 529-541., says : - "I have repeatedly endeavoured to verify Mr. Audubon's account of the rattlesnake ascending trees, which has been confirmed." Now, a great part of that account by Audubon consists of the description of a rattlesnake chasing a squirrel up and down a tree. Does Mr. Taylor wish us to understand that this part of the account has been confirmed by him? I ask this necessary question, because I cannot suppose that Mr. Taylor would spend his time in repeatedly endeavouring to verify the simple fact that rattlesnakes ascend trees. The fact is already as well established as is the existence of the rattlesnake itself. The merest novice in zoology must know that the muscular power in the bodies of snakes enables them to ascend trees. I anxiously wait for Mr. Taylor's reply. If he has actually seen a rattlesnake chasing its prey up and down a tree, then I will own that I have hitherto been completely in the dark with regard to snakes; and that all the time which I have spent in studying their habits, while I was in the forests of Guiana, has been unprofitable and of no avail. If, on the contrary, Mr. Taylor informs us that his experience goes no farther than to verify the fact that snakes 
do get up into trees, then I take the liberty to remark that he has told us nothing new.

I have been in the midst of snakes for many years : I have observed them on the ground, on trees, in bushes, on bedsteads, and upon old mouldering walls; but never in my life have I seen a snake pursue a retreating prey. I am fully satisfied, in my own mind, that it is not in a snake's nature to do so. A snake would follow its retreating prey in a tree with just about as much success as a greyhound would follow a hare through the mazes of a thick wood. Snakes are always in a quiescent state just before they seize their prey; and their mode of capturing it is by an instantaneous spring, consisting of a bound which never exceeds two thirds of the length of the reptile's body.

As we are now on snakes, and as Mr. Taylor informs us that the names of lis birds and animals " are corrected from the splendid work of Audubon," I beg leave to draw his particular attention to plate 21. of that work. It represents a rattlesnake attacking a mocking-bird's nest. Mr. Swainson, in his critique upon it in the Magazine of Natural History, i. 48, 49., seems lost in admiration at its excellence. He says (after lauding plate 17.), "The same poetic sentiment and masterly execution characterises this picture." "Pictoribus atque poetis," \&c. The mouth of the rattlesnake is wide open, and the fangs are the first things to attract the inspector's notice, being by far the most conspicuous feature in it. There they are on elephant [folio] with their points curved upwards! The artist, in his notes on the 
rattlesnake, addressed to Thomas Stuart Traill, M.D., and inserted in Jameson's Journal, says, that he confined a rattlesnake for three years in a cage. Did he never once get a sight of the fangs all that time? I will allow any body the range of the whole world; and if he can produce one single solitary fang of any snake, great or small, with the point turned upwards, I will submit to be sent to the treadmill for three years. All fangs of snakes are curved somewhat in the shape of a scythe, with their points downwards; and we see clearly that their position in the mouth, and the manner in which they convey the poison, require that their points should be curved downwards.

Mr. Taylor further informs us that " black snakes are called racers, from their occasionally chasing men with great ferocity." Chase argues pursuit and retreat: now, $\mathbf{I}$ affirm that snakes never chase men, nor, indeed, any other animals.

If often happens that a man turns round and runs away when he has come suddenly upon a snake, "retroque pedem cum voce repressit;" while the disturbed snake itself is obliged through necessity (as I shall show by and by), to glide in the same path which the man has taken. The man, seeing this, runs away at double speed, fancying that he is pursued by the snake. If he would only have the courage to stand still, and would step sideways on the snąke's coming up to him, he might rest secure that it would not attack him, provided that he, on his part, abstained from provoking it. I once laid hold of a serpent's tail as it was crossing the path 
before me; and then, as might be expected, it immediately raised itself and came at me, and I had to fight it for my pains; but, until I had seized its tail, it showed no inclination whatever either to chase me or to attack me. Had I been ignorant of the habits of snakes, I should certainly have taken myself off as soon as I perceived that it was approaching the place where I was standing; and then I should have told everybody that I had been pursued by a serpent, and had had to run for my life. This snake was ten feet long.

In 1820, on my way to the interior of Guiana, I accompanied Mr. President Rough to the hospitable house of Archibald Edmonstone, Esq., in Hobbabba Creek, which falls into the river Demerara. We had just sat down to breakfast. I was in the act of apologising for appearing barefoot, and in a check shirt, alleging, by way of excuse, that we were now in the forest, when a negro came running up from the swamp, and informed us that a large snake had just seized a tame Muscovy duck. My lance, which was an old bayonet on the end of a long stick, being luckily in a corner of the room, I laid hold of it in passing, and immediately ran down to the morass. The president and his son followed; and I think that Mr. Edmonstone and his late lamented brother joined them. As the scene of action was within a few yards of the ground on which they stood, they had a full view of all that passed, from the commencement of the fray up to its final close. A number of trees had been felled in the swamp, and the snake had retreated among them. I walked on 
their boles, and stepped from branch to branch, every now and then getting an imperfect sight of the snake. Sometimes I headed him, and sometimes I was behind him, as he rose and sank, and lurked in the muddy water. During all this time, he never once attempted to spring at me, because I took care to manœuvre in a way not to alarm him. At last, having observed a favourable opportunity, I made a thrust at him with the lance; but I did it in a bungling manner, for I only gave him a slight wound. I had no sooner done this, than he instantly sprang at my left buttock, seized the Russia sheeting trousers with his teeth, and coiled his tail round my right arm. All this was the work of a moment. Thus accoutred, I made my way out of the swamp, while the serpent kept his hold of my arm and trousers with the tenacity of a bulldog.

As many travellers are now going up and down the world in quest of zoological adventures, I could wish to persuade them that they run no manner of risk in being seized ferociously by an American racer snake, provided they be not the aggressors: neither need they fear of being called to an account for intruding upon the amours of the rattlesnake (see Jameson's Journal for June, 1827); which amours, by the way, are never consummated in the manner there described. The racer's exploits must evidently have been invented long ago, by some anxious old grandmother, in the back woods of the United States, to deter her grandchildren from straying into the wilds. The account of the rattlesnake's amours is an idle fabrication as old as 
the hills. When I was a lad, it was said, how that, in the plains of Cayenne, quantities of snakes were to be seen knotted together, and how that, on the approach of man, they would immediately dissolve company, and make the rash intruder pay for his curiosity far more severely than Diana of old made Actæon pay for an ill-timed peep. She merely changed the hunter into a stag: they chased the man, and barbarously stung him to death.

When a man is ranging the forest, and sees a serpent gliding towards him (which is a very rare occurrence), he has only to take off in a side direction, and he may be perfectly assured that it will not follow him. Should the man, however, stand still, and should the snake be one of those overgrown monsters capable of making a meal of a man, in these cases, the snake would pursue its course; and, when it got sufficiently near to the place where the man was standing, would raise the fore part of its body in a retiring attitude, and then dart at him and seize him. A man may pass within a yard of rattlesnakes with safety, provided he goes quietly; but, should he irritate a rattlesnake, or tread in cautiously upon it, he would infallibly receive a wound from its fang; though, by the by, with the point of that fang curved downwards, not upwards. Should I ever be chased by a snake, I should really be inclined to suspect that it was some slippery emissary of Beelzebub : for, I will forfeit my ears, if any of old Dame Nature's snakes are ever seen to chase either man or beast. They know better 
than to play pranks, which the dame has peremptorily forbidden.

In the village of Walton there is a cross road known by the name of Blind Lane. One summer's evening, as an old woman, named Molly Mokeson, was passing up the causeway in this lane, a man, by name Wilson, saw a snake gliding onwards in the same direction. "Molly," said he, "look! there's a snake running after you." She turned her head to see what was the matter; and, on observing the snake approaching, fear "seized her withered veins." After getting some twenty yards further up the causeway, she took refuge in a neighbour's house, and sat down in silent apprehension, not having breath enough to tell her troubles. In the mean time, Wilson had followed up the snake, and, being without a stick, he had tried repeatedly to kick it, but had always missed his mark. All of a sudden, the snake totally disappeared. Now, the true solution of this chase is nothing more or less than that the snake had been disturbed by the old woman, and had taken its departure for some other place, but, on seeing a man coming up from behind, it had glided harmlessly along the path which the old woman had taken; and then, to save its life, it had slipped into the weeds in the hedge-bottom.

Nothing was talked of in the village, but how that Molly Mokeson had been chased by the devil; for the good people of Walton, wiser in their generation than the sages of Philadelphia, never dreamed of taking this animal for a real snake; knowing full 
well that snakes are not in the habit of chasing men or women. I was consulted on the important affair; and I remarked, with great gravity, that there was something very strange and awful in it. "If," said I, "Molly has unfortunately been interfering with any other woman's witchcraft; or if she has been writing words with her own blood; or, above all, if there was a strong smell of brimstone in the lane at the time of the chase, then, and in that case, therc is too much reason to fear that the thing which Wilson took for a snake was an imp from the bot. tomless pit, sent up here, no doubt, by the king of sulphur, on some wicked and mischievous errand." Poor old Molly is still alive, but nature is almost done within her; and she is now rarely seen on the cold side of the threshold. Many a time have I bantered old Molly on this serpentine apparition; but she would only shake her head and say, she wished she had been at home that evening, instead of going up Blind Lane.

NOTES ON THE HISTORY AND HABITS OF THE BROWN, OR GREY, RAT.

Some few years after the fatal period of 1688 , when our aristocracy, in defence of its ill-gotten goods, took upon itself to dispose of hereditary monarchy in a way which, if attempted nowadays, would cause a considerable rise in the price of 
hemp, there arrived on the coast of England a ship from Germany, freighted with a cargo of no ordinary importance. In it was a sovereign remedy for all manner of national grievances. Royal expenditure was to be mere moonshine, taxation as light as Camilla's footsteps, and the soul of man was to fly up to heaven its own way. But the poet says, "dicique beatus

Ante obitum nemo, supremaque funera debet ;"

that is, we must not expect supreme happiness on our side of the grave. As a counterpoise to the promised felicity to be derived from this superexcellent German cargo, there was introduced, either by accident or by design, an article destined, at no far distant period, to put the sons of Mr. Bull in mind of the verses which I have just quoted.

This was no other than a little grey-coloured short-legged animal, too insignificant, at the time that the cargo was landed, to attract the slightest notice. It is known to naturalists, sometimes by the name of the Norwegian, sometimes by that of the Hanoverian, rat. Though I am not aware that there are any minutes, in the zoological archives of this country, which point out to us the precise time at which this insatiate and mischievous little brute first appeared among us; still, there is a tradition current in this part of the country, that it actually came over in the same ship which conveyed the new dynasty to these shores. My father, who was of the first order of field naturalists, was always positive on this point; and he maintained 
firmly, that it did accompany the House of Hanover in its emigration from Germany to England. Be this as it may, it is certain that the stranger rat has now punished us severely for more than a century and a quarter. Its rapacity knows no bounds, while its increase is prodigious beyond all belief. But the most singular part of its history is, that it has nearly worried every individual of the original rat of Great Britain. So scarce have these last-mentioned animals become, that in all my life I have never seen but one single solitary specimen: it was sent, some few years ago, to Nostell Priory, in a cage, from Bristol; and I received an invitation from Mr. Arthur Strickland, who was on a visit there, to go and see it. Whilst I was looking at the little native prisoner in its cage, I could not help exclaiming,_- Poor injured Briton! hard, indeed, has been the fate of thy family! in another generation, at farthest, it will probably sink down to the dust for ever!"

Vain would be an attempt to trace the progress of the stranger rat through England's wide domain, as the old people now alive can tell nothing of its coming amongst them. No part of the country is free from its baneful presence : the fold and the field, the street and the stable, the ground and the garret, all bear undoubted testimony to its ubiquity and to its forbidding habits. After dining on carrion in the filthiest sink, it will often manage to sup on the choicest dainties of the larder, where, like Celæno of old, "vestigia fœeda relinquit." We may now consider it saddled upon us for ever. 
Hercules himself, could he return to earth, would have his hands full, were he to attempt to drive this harpy back again to Stymphalus. It were loss of time to dwell on its fecundity. Let any body trace its movements in the cellar, the dairy, the outhouse, and the barn, and he will be able to form some notion of the number of hungry mouths which we have to fill. Nine or ten young ones at a time, twice or thrice during the year, are an enormous increase, and must naturally recall to our minds one of the many plagues which formerly desolated the fertile land of Egypt. In the summer months it will take off to the fields, and rear its young amongst the weeds which grow in the hedgerows; plundering, for their support, the birds' nests with a ferocity scarcely conceivable in so small an animal.

Man has invented various instruments for its destruction; and what with these, and with poison, added to the occasional assistance which he receives from his auxiliaries, the cat, the dog, the owl, the weasel, the ferret, and the foumart, he is enabled, in some degree, to thin its numbers, and to check its depredations.

There are some localities, however, from which it may be effectually ousted, provided you go the right way to work. My own house, than which none in Great Britain can have suffered more from the plundering propensities of the Hanoverian rats, is now completely free from their unwelcome presence. On my return to it in 1813, they absolutely seemed to consider it their own property. They 
had gnawed through thirty-two doors; and many of the oaken window frames were irreparably injured by them. While I was in Guiana, a Dutch lady, named Vandenheuvil, had given me a young tiger-cat, which one of her negroes had taken that day in a coffee field. It was the marjay, which, by the by, Buffon considers untameable. I raised it with great care; and it grew so fond of me, that it would follow my steps like a dog. Nothing could surpass the dexterity with which this little feline favourite destroyed the rats on our reaching home. Towards the close of day it would ascend the staircase; and no sooner did a rat make its appearance from the casements, than it would spring at it with the velocity of an arrow, and never fail to seize it. In 1828, having got, by long experience, a tolerably good insight into the habits of this tormenting quadruped, and having found that it spoiled or pilfered every thing within its reach, I finally resolved that it should look out for another place of residence. Wherefore I carefully searched for all its various entrance holes. These I effectually closed with stone and mortar. I then filled up all useless sewers, and paid great attention to the paving and renewing of those which were absolutely required; fixing, at the same time, in either end of them, a cast-iron grate, movable at pleasure. The bottoms of all the outer doors were done with hoop iron; and the pavement which goes round the house was relaid with particular care. By these precautions, I barred all access to these greedy intruders; and, as no rubbish or lumber 
is now allowed to remain in the different nooks and crannies commonly found near ancient dwellings, there is no place of shelter left to conceal any stray individual whose bowels may chance to yearn for one more repast on cheese or bacon. In the mean time, the cat and the owl meet with no obstructions, while prowling for those which may still linger in the environs. The mice, too, seem to have taken the alarm. In a word, not a single mouse or rat is to be found in any part of the house, from the cellars to the attic stories.

In case it were not convenient or practicable to adopt similar precautions to those already enumerated, I would suggest what follows:-Take a quantity of oatmeal that would fill a common-sized wash-hand basin; add to this two pounds of coarse brown sugar, and one dessert spoonful of arsenic. Mix these ingredients very well together, and then put the composition into an earthen jar. From time to time place a table-spoonful of this in the runs which the rats frequent, taking care that it is out of the reach of innocuous animals. They will partake of it freely; and it will soon put an end to all their depredations.

Rats are fond of frequenting places where there. are good doings; while their natural sagacity teaches them to retire in time from a falling house. This knack at taking care of self seems common both to man and brute. Hence the poet:-

"Donec eris felix, multos numerabis amicos;

Tempora si fuerint nubila, solus eris." 
When Fortune smiles, thy friends are many; But, if she frowns, thou hast not any.

Whilst the rats had all their own way here, they annoyed me beyond measure; and many a time have I wished the ship at Jericho, which first brought their ancestors to these shores. They had formed a run behind the plinth in my favourite sitting-room, and their clatter was unceasing. Having caught one of them in a box trap, I dipped its hinder parts into warm tar, and then turned it loose behind the hollow plinth. The others, seeing it in this condition, and smelling the tar all along the run through which it had gone, thought it most prudent to take themselves off; and thus, for some months after this experiment, I could sit and read in peace, free from the hated noise of rats. On removing the plinth at a subsequent period, we found that they had actually gnawed away the corner of a peculiarly hard-burnt brick, which had obstructed their thoroughfare.

The grey rats are said to destroy each other, in places where they become too numerous for their food; but, bad as they are, I will not add this to the catalogue of their misdemeanours. They can never be in such want of alimerit as to do this; because instinct would teach them that where there is ingress to a place, there is also egress from it; and thus, when they began to be pinched for food, they would take off in a body, or disperse amongst the fields, and live upon the tender bark of trees, and upon birds, beetles, and 
other things which the adjacent ground would afford.

That they move from place to place, in large bodies, cannot well be disputed. A respectable farmer, by name John Mathewman, now living in this neighbourhood, has informed me that, as he was returning home one moonlight night, about eleven o'clock, he suddenly came upon a large drove of rats, near Sandal Three-houses. They were coming up a lane which opened upon the high road; and, as soon as they discovered him, they gave mouth in a general squeal. Those nearest to him rose on their hind legs; and then the whole body separated, and scampered off in all directions. Probably these adventurers were on the look out that night for better quarters.

Rats will occasionally attempt to feed on individuals of the human species when they are asleep. In 1824, I went with that excellent American naturalist, Mr. Titian Peale, down the Delaware, to the neighbourhood of Salem, in order to make researches in ornithology; and we procured good lodgings at a farmer's house. During the night I was disturbed by a movement in the straw mattress on which I lay, of a somewhat suspicious nature; but, being exceedingly tired with our day's exertion, I fell asleep again till about halfpast four, my usual hour of rising. At breakfast, "Madam," said I to the farmer's wife, "I could almost have fancied that there were rats in my mattress last night." " Very likely, Sir," said she, with the greatest composure; and then she told 
me that the year before, whilst she was fast asleep in the bed which I had occupied, a rat began to eat into her shoulder. On saying this, she bared the place to let me have a view of it; and I distinctly saw the marks which the hungry rat had left. "Upon my word, Madam," said I, " though I am not prone to make wry faces at a fair allowance of fleas or bugs, still I must own to you that I have not yet quite made up my mind to be devoured alive by rats; wherefore, if you have no objections, when our breakfast is finished, we will go and take a peep into the interior of the mattress." On ripping it up, no rats were found ; but out bounced seven or eight full-grown mice. The old lady smiled as they ran across the floor; and I thought I could read in her face that she considered I had raised a false alarm.

When I reflect on the numbers and the appetite of the Hanoverian rat, and put down to its account the many depredations which it is perpetually committing, I cannot bring my mind to show it the same good feeling which is extended in this park to the rest of animated nature. In truth, I consider its arrival in our country an event productive of much annoyance to the community at large; and, had I the power, I would send its whole stock, root and branch, back again to the country whence it came; seeing that we have gained nothing by letting it exterminate the original English rat. 
REMARKS ON TREES, WITH REFERENCE TO THEIR BEING PERFORATED BY THE TITMOUSE AND THE WOODPECKER.

The tree, that noble and gigantic son of earth, is the favourite resort of most birds ; and so intimately is it connected with the charming science of ornithology, that he who has neglected to pay attention to it will often find himself at a loss to give correct information, in his description of the habits of the feathered tribes.

The bloom, the fruit, the health and vigour of a tree, are interwoven with the economy of birds. Do you wish to have a view of seven or eight different species of Colibri, collected at one tree? Wait, in patience, till the month of July; when a vast profusion of red flowers on the bois immortel (a tree well known to every planter in Guiana) invites those lovely creatures to a choice repast. Are you anxious to procure the pompadour, the purplebreasted and the purple-throated cotingas? Then, mark the time when the wild guava tree ripens its fruit; and on it you will find these brilliant ornaments of the forest. Is the toucan your object? You have only to place yourself, before the close of day, at the shaded root of some towering mora whose topmost branches have been dried by age, or blasted by the thunderstorm, and to this tree the bird will come, and make the surrounding wilds re-echo to its evening call. Would you inspect the 
nest of the carrion crow? Brittle are the living branches of the ash and sycamore; while, on the contrary, those which are dead on the Scotch pine are tough, and will support your weight. The arms of the oak may safely be relied on ; but, I pray you, trust with extreme caution those of the quickgrowing alder. Neither press heavily on the linden tree; though you may ascend the beech and the elm, without any fear of danger. But let us stop here for the present. On some future day, should $I$ be in a right frame for it, I may pen down a few remarks, which will possibly be useful to the naturalist, when roving in quest of ornithological knowledge. I will now confine myself to the misfortunes and diseases of trees; and I will show, that neither the titmouse nor the woodpecker ever bore into the hard and live wood.

Trees, in general, are exposed to decay by two different processes, independent of old age.

The first is that of a broken branch, which, when neglected, or not cut off close to the parent stem, will, in the course of time, bring utter ruin on the tree. The new wood, which is annually formed, cannot grow over the jutting and fractured part, into which the rain enters, and gradually eats deeper and deeper, till at last it reaches the trunk itself. There it makes sad havoc; and the tree, no longer able to resist the fury of the tempest, is split asunder, and falls in ponderous ruins. But ere it comes to this, the titmouse will enter the cavity in a dry spring, and rear its young ones there. Now, if the diseased or fractured branches were carefully cut 
off close to the bole, you would see the new accession of wood gradually rolling over the flat surface, which, in time, would be entirely covered by it; and then the tree would be freed for ever from all danger in that quarter.

The second process towards decay is exceedingly curious, and cannot well be accounted for. If it takes place to a serious extent, no art of -man can possibly save the tree; and sooner or later, according to the magnitude of the disease with which it has been tainted, it will fall before the force of the raging winds. Should this disease be slight, the timely prevention of rain from penetrating the injured part, will secure the tree from further mischief.

I must here observe that, in animated nature, the vital functions are internal; so that, if the part within be mortally wounded, death is the inevitable consequence. With most trees, and with all those of Britain, it is otherwise. Their vitality is at the periphery, connected with the bark, under which an annual increase of wood takes place, so long as the tree is alive. Should, however, the bark be cut away, the tree will die upwards from the place where all the bark has been destroyed. Not so with its internal parts. You may entirely excavate the interior of a tree; and, provided you leave a sufficient strength of wood, by way of wall, in order that it may be able to resist the fury of the tempest without, taking care at the same time to exclude the rain, your tree will remain in vigour from generation to generation. The internal texture of a tree will perish, without any notice by which we may 
be forewarned of the coming ruin. The disease which causes the destruction takes place in the oak; but more frequently in the sycamore; and most commonly of all in the ash. We will select this last tree by way of elucidation.

Often, when arrayed in all the bloom of vegetable beauty, the ash tree is seen to send forth from its bole, or from some principal branch, a small fungus, which, during the summer, increases to a considerable size. It ripens in the autumn, and falls to the ground when winter's rains set in. The bark through which this fungus sprouted is now completely dead, thougl it still retains its colour; and that part of the wood from which it proceeded is entirely changed in its nature, the whole of its vitiated juices having been expended in forming and nourishing the fungus. Nothing remains of its once firm and vigorous texture. It is become what is commonly called touchwood, as soft and frangible as a piece of cork, which, when set on fire, will burn like tinder. In the mean time, the tree shows no sign of sickness; and its annual increase goes on as usual ; till, at last, the new swelling wood closes over the part from which the fungus had grown, and all appears to go on right again. But, ere the slow process arrives at this state, the titmouse or the woodpecker will have found an entrance, and a place of safety for their incubation. They quickly perforate the distempered bark; and then, the tainted wood beneath it yields to their pointed bills, with which they soon effect a spacious cavity.

Here then we have the whole mystery unfolded. 
These birds, which never perforate the live wood, find in this diseased part of the tree, or of the branch, a place suitable to their wants. They make a circular hole, large enough to admit their bodies; and then they form a cavity within, sufficiently spacious to contain their young. Thus does Nature kindly smooth the way, in order that all her creatures may prosper and be happy. Whenever I see these sylvan carpenters thus employed, I say to them, "Work on ye pretty birds; you do no harm in excavating there: I am your friend, and I will tell the owner of the tree that you are not to blame." But his woodman deserves a severe reprimand. He ought to have cut down the tree, in the autumn after the appearance of the fungus.

On the island where this house stands, two stately sycamores have afforded ample proof of what I have advanced.

One of these, some forty years ago, began to put on a sickly appearance; and I heard my father say that he expected to see it blown down in a heavy gale of wind. In the summer of 1800 , I climbed up to the place where the brown owl formerly used to breed. The hole was full of water, in a branch leading from the bole, at about 20 feet from the ground. Presuming from appearances that the damage was extensive, I took a wimble, and bored into the tree, at the height of 5 feet; then at 3 feet; and lastly, I got a chisel, and cut into it at 3 inches from the walk. Twenty-four gallons of water, having the appearance of strong coffee, were procured from these apertures in the course of the day. After 
this, I put a cap of lead over the hole on the high branch above, leaving an entrance for the owl, should she ever come again; and I drove two long pieces of iron into the bole below the aperture, sufficiently low to form a floor for the owl's apartment, which I made with scraps of stone covered with sawdust. In the summer of the present year, 1835, thirtyfive years from the first operation, I enlarged the lowest hole next the walk 4 inches; and, by the lielp of a little iron shovel, I took from the interior of the tree four large wheelbarrows full of decomposed wood, not unlike coffee grounds in appearance. With this substance, there came out some of the small scraps of stone, which I had used in making the floor for the owl's residence: proof incontestable, that the rain water had gradually destroyed the internal texture of the sycamore, from the broken branch at the height of 20 feet. The tree, though hollow as a drum, "or lovers' vows," is now perfectly healthy.

At a little distance from this, is another sycamore, once a towering and majestic tree. Some fifteen years ago, it put out a fungus, about 25 feet from the ground. I saw, by the enormous size of the fungus, that the tree must give way ere long. In 1826, during a heavy gale of wind, it broke in two at the diseased part; leaving one huge branch, which continued to be clothed with rich foliage every succeeding season. I built a stonework on the remaining part of the trunk, by way of covering; and I made sixteen apartments in it for the jackdaws, planting an ivy root at the bottom. In 
the summer of 1831, another large fungus made its appearance at 8 feet from the ground. One Sunday morning, during a raging tempest, the trunk gave way at the fungus, carrying the remaining branch, the stonework, and the jackdaws' nests, with a tremendous crash, into the lake below. I roofed the remainder of the stump again, leaving an entrance for the owl. It is now quite covered with ivy, and has sent forth a partial vegetation annually from its last misfortune. In June of the present year, another huge fungus came out at 4 feet from the ground. I understand the warning; and I clearly foresee that the final doom of this "statio malefida" volucri is close at hand.

Thus have two sycamores, within a few feet of each other, been a prey to distinct diseases, and both of them afforded an inward retreat to birds. The first, having entirely lost its inside, by the slow-consuming process of wet entering at a broken branch, still flourishes by the art of man. The second, for centuries the ornament of the rock upon which it grew, struck at last by the hand of nature with an inward distemper which nothing could arrest, broke down at intervals in partial ruins; and probably will disappear for ever during the next fierce wintry blast.

There is still another process by which an entrance is prepared for birds in the boles of trees. Frequently a large branch fails without any apparent cause; and it remains dead on the tree for many years. At last, down it comes, having given way close to the stem. On inspection you will find 
that decay has entered deeply into the tree itself, without any aid from rain water. The surrounding live wood, which kept swelling gradually while the dead branch remained on the tree, now that the obstruction is removed, begins to advance over the newly exposed and distempered part. In the mean time, the birds find no difficulty in excavating this part, and there forming a place for incubation, or for a nocturnal residence. Mice and rats will also find their way into these diseased parts of trees. I know of a crab tree in which a mouse lives. Its hole is about 5 feet from the ground.

I have written this paper, first, to show the true habits of the titmouse and the woodpecker relative to their choice of a place for their incubation; and, secondly, to catch the eye of the proprietor of the American Quarterly Review, who, I am informed, has thought fit to heap anonymous abuse upon me, with an unsparing hand. Let this sage discerner of ornithological merit turn to pages 200. and 343 . of the Biography of Birds, and then blush for American ignorance.

NOTES ON THE HABITS OF THE JAY.

OUR peas and ripe cherries have attractions which this well-known bird cannot resist. To these it unfortunately resorts, and loses its life by the gun of the watchful gardener, who never fails to magnify 
a petty act of plunder into a downright commission of felony. Forgetful of the caution which is its peculiar characteristic at other seasons of the year, the jay becomes remarkably daring and adventurous in pea and cherry time. To this unlucky yearning for the good things of the garden, I attribute the general scarcity of this truly British bird. Even here the jay is never abundant, though a safe retreat is always open to it; so that, whilst the magpie is very numerous, it is comparatively a scarce bird. Two or three nests, at most, are all I can annually produce. These, by the way, I find are much more compact, and better put together, than those which naturalists have hitherto described.

The nest of the jay is never seen near the tops of trees, like those of the magpie and the crow. He who feels inclined to study the nidification of this bird must search the lower branches of the oak, or inspect the woodbine mantling round the hazel. In such situations he will find the nest, which mostly contains six eggs; and, if he advances with "cautious step and slow," he may approach within a yard of it before the sitting bird will take its flight.

There seems to be an erroneous opinion current concerning some birds, which are supposed to forsake their eggs if they are handled, be it ever in so slight a manner. This requires some explanation. If you rush up abruptly to a nest, so as to terrify the old bird, you will find, with very few exceptions, that it will forsake the place. If, on the contrary, you approach the nest of any bird in gentleness and silence, and allow the owner to slip off without being 
fluttered, you may take the eggs out of the nest, and blow upon them, and put them in your mouth if you choose, or change their original position when you replace them in the nest, notwithstanding which the bird will come back to them (even though it be a ringdove), and continue to sit on them as attentively as before.

The jay being one of those birds which have their brilliant colours prior to their first moulting, you will find the male and female so much alike, that it will be no easy matter to distinguish the one from the other.

The young of this bird are born blind: of course, the parent bird never covers the eggs with any part of the materials which form the nest, when she has occasion to be absent.

Here let me remark the immense difference that exists betwixt a newly hatched bird with its eyes open, and one newly hatched with its eyes closed. The first can walk and find its food in a very short time; the second is helpless in the extreme for many days, and cannot support its own weight. A scientific friend in the United States of North America has asked my opinion of our English account concerning a young cuckoo, which, on the very day that it was hatched, was actually seen retrograding up the side of a liedge sparrow's nest with a young hedge sparrow on its back. After reaching the top, it rested for a moment, and then, with a jerk, threw off its load quite clear of the nest. No bird in the creation could perform such an astounding feat under such embarrassing circum- 
stances. The young cuckoo cannot, by any means, support its own weight during the first day of its existence. Of course, then, it is utterly incapable of clambering, rump foremost, up the steep side of a bedge sparrow's nest with the additional weight of a young hedge sparrow on its back. Add to this, that an old bird, the young of which are born blind, always remains on the nest during the whole of the day on which the chick is excluded from the shell, in order to protect it. Now, the old hedge sparrow, in the case just mentioned, must have been forced from her nest by the accidental presence of an intruder. Her absence, then, at this important crisis, was quite contrary to her usual economy, for she ought to have been upon the nest. It follows, then, that instinct could not have directed the newly hatched and blind cuckoo to oust the hedge sparrow, even though it had strength to do so, because the old bird would have been sitting close on the nest, but for the circumstance which forced her from it, namely, the accidental presence of an intruder The account carries its own condemnation, no matter by whom related or by whom received. I had much rather believe the story of baby Hercules throttling. two snakes in his cradle.

"Parvus erat, manibusque suis Tirynthius angues

Pressit, et in cunis jam Jove dignus erat."

When naturalists affixed the epithet glandarius to the name of the jay, they ought also to have accorded it to the jackdaw, the rook, the carrion crow, and the magpie, not forgetting the pheasant and the 
ringdove. All these birds feed voraciously on the acorn ; and, with the exception of the two last mentioned, they bury it in the ground, not in hoarded heaps, but separately, here and there, as fancy may direct them.

When the snows of winter have fairly set in, and thus prevented the jay from finding a supply of acorns amongst the fallen leaves in the woods, it is then seen flitting from hedge to hedge in the vicinity of pea and bean stacks, where it may be observed clinging to the sides of these in quest of uncovered pods; and thus it acquires part of its scanty provender, "till the vernal suns and showers" have dissolved the accumulated snow, and cleared its former haunts. To these it returns once more, and consumes myriads of insects in comparative safety. But when the fatal season of peas and ripe cherries arrives, scarcely any thing short of death can deter this unfortunate bird from participating in the proffered feast. The gardener, in discharging his gun at it, is sure to make bad worse by his officious interference; for, in his eagerness to kill the poor bird, he never once reflects that the contents of his piece do ten times more harm to the fruit and to the tender shoots of the cherry tree, than the dreaded presence of half a dozen jays, all with empty stomachs.

Towards the end of April, when nature smiles around, and the woods begin to expand their opening bloom, he who loves to wander through them, in quest of ornithological adventures, will sometimes hear a profusion of imitative tones not far from the 
place where he is straying, now hoarse and sonorous, now lowered and subdued, and composed of modulations almost approaching to those of song: they are produced by ten or a dozen sprightly jays, assembled in merry mimicry and glee, ere they depart in pairs to select a place for approaching incubation. This is the only period of the year in which the jay shows a disposition to be social ; for, at other times, it is a wandering solitary bird, and does not allow its young to associate with it, after they have arrived at a state to be able to provide for themselves. Here, where the jay is encouraged and protected, this part of its economy may be easily verified.

This bird would probably not be noticed as having anything remarkable either in shape or plumage, were it not for the loveliness of its bastard wing and greater covert feathers. The blue, the black, and the white in them are so exquisitely blended, that the eye is never tired with gazing on the colours. Nothing can possibly be conceived more charming. No other known bird in the creation possesses such a rich exhibition of colouring in the bastard wing and greater coverts. It belongs exclusively to this one species of bird: it is the indubitable and never-failing mark of the jay of Europe; a bird which will ever have a friend in me, notwithstanding its acknowledged depredations in gardens and in orchards. Its pilferings are of short duration: they are too trivial to cause uneasiness, and of far too light a nature to demand the forfeiture of life. 


\section{NOTES ON THE HABITS OF THE MAGPIE.}

THIs beautiful frequenter of our woods and plains was notorious, two thousand years ago, for pertness of character and volubility of tongue. Ovid, who knew more of birds than any man of his time, gives us an account of a family of young ladies in Macedonia, who were all changed into magpies; and he expressly tells us, that they retained their inordinate fondness for gabble long after they had lost the lovely form of woman.

"Nunc quoque in alitibus, facundia prisca remansit, Rauca garrulitas, studiumque immane loquendi." And still their tongues went on, though changed to birds, In endless clack, and vast desire of words.

If similar transformations were to take place nowadays, I suspect that many a father here in England would have to look for his lost daughter, chattering amongst the lofty branches of the trees in his park.

I protect the magpie with greater care than, perhaps, any other bird, on account of its having nobody to stand up for it. Both rich and poor seem to entertain so great an antipathy to this gay and lively bird in its wild state, that I often wonder how the breed has managed to escape utter extirpation in this populous district. The country gentlemen all agree in signing the death warrant of this friendless bird, because it is known to suck 
eggs, and to strangle young game; whilst, in general, the lower orders have an insurmountable prejudice against it, on the score of its supposed knowledge of their future destiny. They tell you that, when four of these ominous birds are seen together, it is a sure sign, that, ere long, there will be a funeral in the village; and that nine are quite a horrible sight. I have often heard countrymen say that they had rather see any bird than a magpie; but, upon my asking them the cause of their antipathy to the bird, all the answer that I could get was, that they knew it to be unlucky, and that it always contrived to know what was going to take place. My keeper both hates and fears a magpie; but self-interest forces upon the fellow the unpleasant task of encouraging the breed, in order to keep well with me. He was once in conversation with the keeper of a neighbouring gentleman, at the door of a little alehouse in the village of Heath, when a magpie flew into a tree hard by. "I must have thee killed," said the gentleman's keeper, "otherwise there will be a blow up betwixt me and my master." "Ah !" rejoined my keeper, "were I to kill a magpie, my master would soon blow me out of his service." The keeper thought this too good to be lost, and I had it from his own mouth.

I love in my heart to see a magpie, for it always puts me in mind of the tropics. There is such a rich glow of colour, and such a metallic splendour of plumage, in this bird, that one would almost be 
apt to imagine it must have found its way here from the blazing latitudes of the south.

I am fully aware that it has propensities of a sufficiently predatory nature to bring it into general disrepute with civilised man; but let us remember that, like the carrion crow, it only exercises them to any serious extent for about two months in the spring of the year. At that season, it certainly commences operations with surprising assiduity. Cacus himself, that ancient thief, when he was about to steal the cows of Hercules, never exhibited greater cunning than that which this bird puts in practice after it has discovered a hen's nest in the yard, or a place of sitting game in the field. Both the magpie and the carrion crow transfix the eggs with their beaks, and then convey them through the air.

After the season of incubation is over, the magpie becomes a harmless bird (unless the pilfering of a little unprotected fruit be considered a crime), and spends the remainder of the year in works of great utility to man, by destroying millions of insects, and by preventing the air from being infected with the noxious effluvium arising from the scourings of slaughter-houses. The cattle, too, are in some degree benefited by the prying researches of this sprightly bird. At a certain time of the year, it is often seen on the backs of sheep and oxen, freeing them from vermin, which must be exceedingly troublesome to them. In Demerara, where the magpie does not exist, this friendly office is performed by a hawk. Widely different 
is the object of the jackdaw's visit to the backs of sheep and oxen: it goes there for fleece; the magpie for filth.

I cannot suppose, with some naturalists, that the dome of the magpie's nest is intended for a defence; because the hole at which the bird enters is always open to an enemy, while the contents of the nest are quite visible through the dome itself.

The young of the magpie being hatched blind, the eggs are never covered when the parent bird leaves the nest. I am satisfied in my own mind, that neither the magpie, nor any other bird, can have the least idea that their nests will be robbed, up to the very moment when their eggs, or their young, are taken away. Did they apprehend such a disaster, we may be assured that their first object would be to build their nests in a place out of harm's way. Now, the magpie generally chooses the site for its intended incubation in a spot the most exposed that can possibly be imagined. It will continue to work at the structure of its nest, although we visit the nest two or three times a day; and it will return to the nest, and sit upon its eggs, after those eggs have been handled times out of number. Nay, more; you may take away its own eggs, and substitute those of some other bird, and it will hatch them, and rear the produce.

The magpie (and we may include all other birds) shows not that intensity of feeling for its eggs which it is known to have for its young. Thus, if you take the eggs from the nest and place them on the ground, the magpie will abandon them for 
ever; but if you remove the young to a place to which the parent bird can have access, she will regularly bring them a supply of food.

When there is an addle egg, it is allowed to remain in the nest during the entire process of rearing the young. Birds which make their nests in walls, or in the holes of trees (the starling to wit), bring out the addle egg, which has remained from the last year's incubation, and drop it on the ground, when they begin to renew the nest.

The magpie builds its nest in any tree, no matter of what kind; and it is very partial even to the lowly thorn bush in the hedgerow. The apple tree in the garden; the lonely ash in the meadow; the alder in the swamp; and the oak in the heart of the forest, far from the abode of man; all have their attractions for the magpie; and in these it will form its nest, which is invariably composed of sticks, and clay or earth, and lined with fibrous roots. When I am informed that magpies line their nest with wool, I suspect that there is either an error in the statement, or that the modern magpie has conformed to the times, and has brought to her nest a kind of furniture wholly unknown to her ancestors.

The magpie lays from three to nine eggs; but seven seems to be the average number, varying in size, and shape, and colour, as much as those of the carrion crow.

The female magpie has so near a resemblance to the male, that you can scarcely distinguish the one from the other. This is the case with all 
birds, where the brilliant plumage obtains before the first moulting.

The sight of a magpie always gives me pleasure ; its long tail, and its distinct markings of white and black, having a beautiful effect as it darts through the air. You may know this bird at a very great distance, either on the ground, or in a tree, by the frequent and brisk movement of its tail ; always up and down, never sideways.

The magpie seems to have found out that it has at least one friend left in our part of the country. Last year I had thirty-four nests, all of which ushered their young into the world at large; making, on an average of five to the nest, including the parent birds, 238 individuals ; an increase quite sufficient, one would think, to supply all the wise men of the county witl any quantity of omens. The name of wise man, in Yorkshire, is always given to one who professes to deal in the black art. Even well-educated people of the nineteenth century go to him, in order to recover things lost ; or to be put on the right scent, if a cow, or horse, or pig, or relative, be missing.

Magpies are social, though not gregarious in the strictest sense of the word. In places where they are beyond the reach of molestation, you may see them in little parties of fifteen or twenty together, flitting from tree to tree in noisy conversation. Sometimes they will rise to a great height in the air, passing through it with a velocity which seems hitherto to have escaped the notice of naturalists.

Like all other birds in a wild state, magpies 
become vociferous at the approach of night; and he who loves to watch the movements of animated nature, may observe them, in small detached companies, proceeding to their wonted roostingplaces, in some wood of spruce, pine, or larch, which they seem to prefer to any other. There they become valuable watchmen for the night. Whoever enters the grove is sure to attract their special notice; and then their chattering is incessant. Whenever I hear it during the night, or even during the day (except towards nightfall), I know that there is mischief on the stir. Three years ago, at eleven o'clock in broad day, I was at the capture of one of the most expert and desperate marauders that ever scourged this part of the country. He had annoyed me for a length of time; and was so exceedingly cunning, that, when we went in pursuit of him, he always contrived to escape, either by squatting down in the thick cover of the woods, or by taking himself off in time, when he saw us approach. At last, he owed his capture to the magpies. We were directed to the place of his depredations by the incessant chatterings of these birds in the tops of the trees, just over the spot where he was working in his vocation. He had hanged fourteen hares; and the ground was so covered with brambles and brushwood, that, when we surprised him, he told us that we never should have found him, had it not been for the cursed magpies. His name was Kirk. In the course of the following summer, he set out on his 
travels towards New South Wales, at the king's expense; having been convicted, at the York assizes, of an overweening inclination for his neighbour's mutton, to which he had helped himself most abundantly.

NOTES ON THE HABITS OF THE CHEGOE OF GUIANA, BETTER KNOWN BY THE NAME OF IJIGGER; AND INSTANCES OF ITS EFFECTS ON MAN AND DOGS.

\section{—_ "Priore relictâ}

Sede, novis domibus habitant, vivuntque receptæ." Ovid. Met.

Leaving their former haunts, beneath the skin

They form new settlements, and thrive within.

THis apparently insignificant insect far outdoes the bug in the exercise of its noxious qualities. The bug attacks you in an open manner, makes a hearty meal, and then retires to enjoy it: but the chegoe commences its operations upon you so gently, that they are scarcely felt; and it terminates them in a way that calls for your most serious attention. In a word, it approaches you with such insinuating address, that you absolutely feel a kind of gratification at the very time that it is adopting measures which will infallibly end in your certain torment.

Soon after the chegoe has entered your skin, you experience a pleasant itching kind of sensation, by which you begin to suspect that all is not right; 
and, on taking a nearer view of the part, you perceive that the skin is somewhat discoloured.

I know it is supposed by some people, that the accounts concerning the chegoe have been much exaggerated. I am not of this way of thinking, for I myself have smarted under its attacks; and I have minutely inspected the foot of a negro, which was a mass of ulcers, formed entirely by the neglected ravages of the chegoe.

Guiana is the native country of this insect. In that hot and humid region, which is replete with every thing that can please our imagination, or administer to our wants, we must not be surprised to find here and there some little drawback; some few obstructions in our way; some thorny plants to impede our journey as we wander on.

The chegoe resembles a flea : and, had you just come out of a dovecot, on seeing it upon your skin, you might easily mistake it for a small pigeon flea; although, upon a closer inspection, you would surmise that it is not capable of taking those amazingly elastic bounds, so notorious in the flea of Europe.

Not content with merely paying you a visit, and then taking itself off again, as is the custom of most insects, this insidious miner contrives to work its way quite under your skin, and there remains to rear a numerous progeny. I once had the curiosity to watch the movements of a chegoe on the back of my hand, a part not usually selected by it to form a settlement. It worked its way pretty rapidly for so small an insect. In half an hour it had bored quite through the skin, and was completely out of 
sight. Not wishful to encourage its intended colony, "Avast, there! my good little fellow," said I; "we must part company without loss of time. I cannot afford to keep you, and a numerous family, for nothing: you would soon eat me out of house and home." On saying this, I applied the point of my penknife to the place where the chegoe had entered, and turned it loose upon the world again.

In the plantations of Guiana, there is generally an old negress, known by the name of Granny, a kind of "Junonis anus," who loiters about the negro yard, and is supposed to take charge of tlie little negroes who are too young to work. Towards the close of day, you will sometimes hear the most dismal cries of woe coming from that quarter. Old Granny is then at work, grubbing the chegoe nests out of the feet of the sable urchins, and filling the holes with lime juice and Cayenne pepper. This searching compound has two duties to perform: first, it causes death to any remaining chegoe in the hole; and, secondly, it acts as a kind of birch-rod to the unruly brats, by which they are warned, to their cost, not to conceal their chegoes in future: for, afraid of encountering old Granny's tomalawk, many of them prefer to let the chegoes riot in their flesh, rather than come under her dissecting hand.

A knowing eye may always perceive when the feet of negroes are the abode of the chegoe. They dare not place their feet firmly on the ground, on account of the pain which such a position would give them; but they hobble along with their toes turned up: and by this you know that they are not 
suffering from tubboes (a remnant of the yaws), but from the actual depredations of the chegoes, which have penetrated under the nails of the toes, and there formed sores, which, if not attended to, would, ere long, become foul and corroding ulcers. As I seldom had a shoe or stocking on my foot from the time that I finally left the sea coast in 1812, the chegoe was a source of perpetual disquietude to me. I found it necessary to examine my feet every evening, in order to counteract the career of this extraordinary insect. Occasionally, at one overhauling, I have broken up no less than four of its establishments under the toe nails.

In 1825, a day or two before I left Guiana, wishful to try how this puny creature and myself would agree during a sea voyage, I purposely went to a place where it abounded, not doubting but that some needy individual of its tribe would attempt to better its condition. Ere long, a pleasant and agreeable kind of itching under the bend of the great toe informed me that a chegoe had bored for a settlement. In about three days after we had sailed, a change of colour took place in the skin, just at the spot where the chegoe had entered, appearing somewhat like a blue pea. By the time we were in the latitude of Antigua, my guest had become insupportable; and I saw there was an immediate necessity for his discharge. Wherefore, I turned him and his numerous family adrift, and poured spirits of turpentine into the cavity which they had occupied, in order to prevent the remotest chance of a regeneration. 
The Indian and negro wenches perform the operation of extracting chegoes with surprising skill. They take a pin, and, by a very slow process, they lay the part bare, and contrive to work quite round the bag which contains the chegoe and its offspring. As soon as this has been effected, they turn the bag out, whole and uninjured; by which means none are left in the hole to form a new colony.

For my own part, I never troubled these gentle operators; although I have looked on many a time, and admired their exquisite skill, whilst they were fingering the toes of my acquaintance. Once, however, I had it not in my power to be my own surgeon, and, on that occasion, a faithful old negro performed the friendly office.

I was descending the Demerara, with an inveterate tertian ague; and I was so much exhausted by sitting upright in the canoe, that I no sooner got ashore at an Indian's hut, than I lay down on the ground at full length. Sickness had pressed so heavily on me, that I was callous to the well-known feeling which the chegoe causes. I was quite unconscious that there were nine thriving nests of chegoes in my back, until one was accidentally observed by the old negro; and this led to the discovery of the rest. I handed him my penknife, and told him to start the intruders. Sick as I was, I wished an artist were present at the operation. The Indian's hut, with its scanty furniture, and bows and arrows hanging round; the deep verdure of the adjoining forest; the river flowing rapidly by ; myself wasted to a shadow; and the negro grinning 
with exultation, as he showed me the chegoes' nests which he had grubbed out; would have formed a scene of no ordinary variety.

Dogs are often sorely tormented by the chegoe; and they get rid of them by an extremely painful operation. They gradually gnaw into their own toes, whining piteously as they do it, until they get at the chegoe's nest. Were it not for this singular mode of freeing themselves from the latent enemy, dogs would absolutely be cripples in Guiana.

But it is time to stop. I have penned down enough to give the reader a tolerably correct idea of one of the smallest, and, at the same time, one of the most annoying, insects, which attack both man and beast in the interminable region of Guiana.

NOTES ON THE HABITS OF THE DOVECOT PIGEON.

"Aspicis ut veniant ad candida tecta columba, Accipiat nullas, sordida turris aves."

Ovid. Tris.

See, to the whitewash'd cot what doves have flown:

While, that unwhitewash'd, not a bird will own.

Bx this it appears, that the old Romans paid considerable attention to the raising of pigeons.

Our common dovecot pigeon is only a halfreclaimed bird; not being sufficiently domesticated to be deemed private property in the strictest sense of the word. Thus, I may raise any quantity of these pigeons; but, if they should forsake my 
dovecot, and retire to that of my neighbour, I cannot claim them. However, in order that dovecot pigeons may not fall into the hands of those who contribute nothing to their support, the legislature has enacted a fine of forty shillings, to be paid by him who has been convicted of having shot a dovecot pigeon.

This act, till of late years, was of great use to the farmer; for it enabled him to raise this useful bird in vast abundance: but now the times are changed. The owners of dovecots have to complain, not only of bargemen, who shoot their pigeons along the whole line of the canals whenever an opportunity offers, but also of a plundering set of land vagabonds, who attack the dovecots in the dead of the night, and sometimes actually rob them of their last remaining bird. The origin of this novel species of depredation can be clearly traced to the modern amusement, known by the name of a pigeon-shooting match. A purveyor is usually engaged by the members. He offers a tempting price to poachers and other loose characters, and they agree to supply him with any quantity of dovecot pigeons, to be ready for the day on which the cruel exhibition is to take place. Generally, under the covert of a dark night, these hired thieves go to the place where they have previously seen a ladder, and carry it off to the devoted dovecot, upon the outside of which they mount, and with great caution fix a net to the glover, or aperture, on the top of the building. After they have effected this, they descend from the roof, and im- 
mediately force the door to get at the pigeons. Should, however, their original survey of the dovecot, prior to their mounting on it, have shown them that the door is strong enough to resist their attempts to break it open, they take the precaution to leave a man on the roof, where he seizes the pigeons as soon as they become entangled in the net. In the mean time, his associates below tap sufficiently loud at the door of the dovecot to cause the pigeons to start from their roost and try to escape. Thus the hopes of the farmer are utterly destroyed, and a supply of birds is procured for the shooting matches in a manner not over and above creditable to civilised society. It remains with the members of the club to decide, whether it be honourable or just in them to encourage these midnight depredators. They must be aware that all the pigeons which they buy are old ones; and that old ones are never offered for sale by the owners of dovecots. The dovecots in this neighbourhood have been robbed repeatedly; and it is well known that the plgeons which have been stolen from them have fallen at shooting matches near forty miles distant.

No farm-yard can be considered complete without a well-stocked dovecot, the contents of which make the owner a most ample return, and repay him abundantly for the depredations which the pigeons are wont to make upon his ripening corn. $\mathrm{He}$ commands a supply of delicious young birds for his table; and he has the tillage from the dovecot, which is of vast advantage to his barley 
land. Moreover, the pigeons render him an essential service, by consuming millions of seeds which fall in the autumn, and which, if allowed to remain on the ground, would rise up the following year, in all the rank exuberance of weed, and choke the wholesome plant.

A dovecot ought to be well lighted; and it should be white-washed once every year. The tillage which it produces may be removed early in November, and again at the end of February. The young of the dovecot pigeon, like all others of the columbine order, are reared in a nest lined by their own dung; which, if left in the hole after the birds are gone, is apt to harbour vermin. Wherefore, cleanliness dictates its early removal.

No dovecot can possibly thrive if rats have found an entrance into it. These cruel and audacious plunderers will destroy every young pigeon within their reach. Oust them you must, and preclude their return, be the cost ever so great; otherwise, diappointment will most assuredly be your lot.

The barn-owl and the starling are harmless unoffending visitors to the dovecot: they repair to it merely for shelter, or for a breeding-place; so that I always like to see them enter mine. It is a lofty and a spacious building; and last season it furnished seventy-three dozens of young pigeons. The walls were made with flues, by the judicious use of which we had a very early supply for the table; but, through some neglect on the part of the attendort, a fire took place, which threatened destruction to the surrounding buildings. In con- 
sequence of this, the flues were no longer heated, and they have continued in disuse since that time. Though owls, and hawks, and crows, and magpies, are allowed an unmolested range in the vicinity of this dovecot, still it is acknowledged to be one of the most productive in the county.

There is a peculiarity in the habits of the dovecot pigeon which ought not to pass unnoticed. 'Though this bird will often perch on trees in the daytime, it has never been known to roost on them during the night. Neither will it pass the night in the open air, except in cases of the greatest emergency. I have an aged elm here, of gigantic size, to which both the dovecot pigeon and the wild ring-pigeon will frequently resort. It is anusing to watch the peculiar habits of these two different species of birds. They seem to come to the tree solely for their own convenience, and not with any intention to enjoy each other's company ; and they appear to be as devoid of mutual signs of courtesy, as are our own countrymen when seated in a foreign diligence. I am positive that there will never be a union betwixt the dovecot pigeon and the ringdove. A long series of observations, which I have been enabled to make, tends to convince me more and more of the impossibility.

The dovecot pigeons, like the rest of the genus, are remarkable for retiring to their roost at an early hour, and for leaving it late in the morning : thus fulfilling only half of Poor Richard's maxim of,

" Early to bed, and early to rise,

Makes a man healthy, wealthy, and wise." 
These pigeons never lay more than two eggs at one sitting. Indeed, I should be most surprised were it satisfactorily proved that any pigeon ever sits on three eggs.

Nothing can surpass the attachment of these birds to the cot of their choice. Provided you do not absolutely molest them by the repeated discharge of fire-arms, they can scarcely be driven from it. You may unroof their habitation; and, though you leave it in that dismantled state for weeks together, still the pigeons will not forsake it. At their early hour of roosting, they will approach within three or four yards of the workmen, and then take shelter in the holes of the roofless walls, where they remain for the night.

Much might be written by the ornithologist on the intimacy which would exist betwixt man and the feathered tribes, if man would condescend to cultivate it. Were I " close pent up in the social chimney corner," on some dismal winter's evening, with an attentive "Eugenius" by my side, I would show him the cause of shyness which exists betwixt the birds and us; and, amongst other things, I would prove to him that no bird ever anticipates the return of man to the vicinity of its nest, by the supposed act of removing its "young to new quarters." The pretended discovery of this reasoning quality in birds may be just the thing to raise the writer in the estimation of the editor of the American Quarterly; but it won't go down here in England.

Our ancestors generally built their dovecots in 
an open field, apart from the farm-yard; fearing, probably, that the noise and bustle occasioned by the rustic votaries of good Mother Eleusina might interrupt the process of incubation, were the dovecots placed in the midst of the buildings dedicated to husbandry.

Birds very soon get accustomed to the sounds of civilised life, be they ever so loud, except those which proceed from the discharge of a gun; and even those, in some few cases of extreme hunger, will not deter a famished wild bird from approaching the place where nutriment can be found. How unconcernedly the daw sits on the lofty steeple, while the merry chimes are going! and with what confidence the rooks will attend their nests on trees in the heart of a town, even on the busy market day! The report of fire-arms is terrible to birds; and, indeed, it ought never to be heard in places in which you wish to encourage the presence of animated nature. Where the discharge of fire-arms is strictly prohibited, you will find that the shyest species of birds will soon forget their wariness, and assume habits which persecution prevents them from putting in practice. Thus, the cautious heron will take up its abode in the immediate vicinity of your mansion; the barn-owl will hunt for mice under the blazing sun of noon, even in the very meadow where the hay-makers are at work; and the wigeons will mix, in conscious security, with the geese, as they pluck the sweet herbage on your verdant lawn; where the hares may be seen all day long, now lying on their sides 
to enjoy the warmth of the sun, and now engaged in sportive chase, unbroken-in-upon by enemies, whose sole endeavour is to take their lives.

NOTES ON THE HABITS OF THE STORMCOCK, OR MISTLETOE THRUSH.

\footnotetext{
"Te, dulcis conjux, te solo in littore secum,

$\mathrm{Te}$, veniente die, te, decedente, canebat."

For thee, sweet mate, for thee he pour'd his lay, At early dawn, and at the close of day.
}

IT is a pleasing and ingenious way to account for the song in birds, by supposing that it is given to them by Nature, in order that they may enliven the female during the lonely task of incubation. At that interesting season of the year, one might really imagine that the song of the male is absolutely uxorious; and, in truth, it may be, for aught I know to the contrary. No cow ever chewed her cud more deliberately than I have weighed this matter in my own mind; and, after all, I am not one jot the wiser. My speculations in April have all been shivered to atoms in November, and I am left in the midst of uncertainty. To-day, I hear a male bird singing close to the bush where his female is on her nest; and, five months hence, I shall hear a male bird sing, in apparent ecstasy, when the chilling season of the year peremptorily forbids the female to make any preparations for the nursery. Baffled 
at every point, I sometimes peevishly ask myself, Why should nature have made a provision in the male blackbird, in order that he may soothe his incubating female, and have denied that provision to my favourite, the carrion crow? And then I answer my own question, by whispering to myself, that the she carrion may possibly experience wonderful delight in listening to the hoarse croaking of her partner; just as the old Scotchwoman did, when she used to gaze at the carbuncle on her husband's nose. In a word, I know nothing, absolutely nothing, about the song in birds. The raven will whistle you a tune so true and pleasing that you feel quite enchanted with his performance; whilst his congener, the carrion crow, notwithstanding all your pains to instruct him, will remain as unmusical as Paddy's fiddle, which was dumb for want of catgut. We listen with delight to the many species of male birds which make the groves resound with their melody; and we cannot imagine why the females so seldom venture an attempt at song; for we know that with us both ladies and gentlemen are full of fine sounds. Wherever a Braham is heard, there is sure to be a Billington not far off.

However, should it be the case, in ornithology, that Nature has ordered the male to sing his female to repose, there are some exceptions to the supposed general rule. I may adduce the stormcock by way of example; for he warbles nearly the year throughout. I have often heard him pour forth his wild and plaintive notes in the months of August, October, November, and December, and in every following 
month, until the sun has entered into cancer, at which period he seems to unstring his lyre for a few weeks. Towards the close of December his song is particularly charming; and it becomes more frequent as the new year advances. I remember well (indeed, I noted down the circumstance,) that, on December 21. 1827, his carol was remarkably attractive. He warbled incessantly from the top of a lofty elm, just as the poor from a neighbouring village were receiving corn under it, in memory of St. Thomás the apostle. In the olden time, it was a common practice throughout the land to distribute corn to the needy, on the day in which the festival of this glorious saint is kept. At present the good dole seems fast approaching to its latter end. Probably in a few years more it will fall a victim to the times, and be trodden under foot in the modern march of intellect.

This bird, though usually known by the name of the mistletoe thrush in many parts of England, is invariably called the stormcock by all the lower orders in our neighbourhood; not that it delights in storms more than in fine weather, but that Nature has taught it to pour forth its melody at a time of the year when the bleak winds of winter roar through the leafless trees. Should, however, a few days of calm and warmth succeed to the chilling blast, then the stormcock is heard to sing, if anything, more sweetly than before.

The stormcock is a decided inhabitant of trees, except sometimes when in quest of food; for at that . time he may be seen on the ground, and in berry- 
bearing shrubs. But in shrubs I have never been able to find his nest, which is generally placed either in the forked branches of the forest trees, or in those of the larger fruit trees, sometimes very high up, and sometimes within $5 \mathrm{ft}$. of the ground. The outside of the nest is composed of dried grass, to which is added a little green moss; whilst the inside contains a lining of dried grass alone, on which the female commonly lays five eggs, speckled over with chocolate-coloured spots, of a lighter and a darker shade, on a greyish-green ground.

During the period of the breeding season, the habits of the stormcock undergo a noted change. At other times of the year, except in cherry-time, and when the seeds of the different species of the service tree are ripe, this bird carefully avoids the haunts of man; but no sooner does the time arrive in which it has to make its nest, than it draws near to our habitations with the utmost confidence, and forms its nest in places the most exposed to our view. There both male and female protect their charge with matchless courage. On the approach of an enemy you immediately hear their singular cry, which somewhat resembles the sound produced by striking the teeth of a comb smartly with your finger; and you see the parent birds dashing incessantly at the crow, the cat, or the magpie, until they clear the coast. This year there is a stormcock's nest within fifteen yards of the place where the masons are at work. Our tame magpie, which is allowed its freedom, and the use of its wings, seized the female, some days ago, and brought her 
close to the masons. The male bird instantly came up, and rescued his mate, by fighting the magpie, until he made it let go its hold. "Causa viæ conjux." It was to save his female that he advanced so undauntedly into the midst of his mortal enemies : nothing else could have induced him to face the danger. I fancy that I hear him say-

" Si fata negant veniam pro conjuge, certum est,

Nolle redire mihi: letho gaudete duorum:"

"If you won't give my poor dear up to me, here I stay: you may kill us both." This loving couple retired triumphant to their nest; but the female lost half of her tail in the fray.

The stormcock surpasses all other thrushes in size, and is decidedly the largest songster of the European birds. He remains with us the whole of the year; and he is one of three birds which charm us with their melody during the dreary months of winter, when the throstle and the lark are silent, and all the migratory birds have left us, to sojourn in warmer climates. On this account I prize him doubly. He appears to be gregarious in the months of August and September. I have occasionally counted from forty to fifty of these birds in a flock; and I suspect that they are sometimes mistaken for an early arrival of fieldfares, by those who pay attention to the migration of birds.

The stormcock is remarkably fond of the berries of the mountain-ash. He who loves to see this pretty songster near his dwelling would do well to . plant a number of mountain-ashes in the midst of 
his pleasure-grounds: they are of quick growth, and they soon produce an abundance of berries.

Whilst the fruit of these trees affords a delicious autumnal repast to the stormcock, the branches which bear the berries are well known to be an effectual preservative against the derilish spells of witchcraft. In the rillage of Walton I have two small tenants: the name of one is James Simpson, that of the other Sally Holloway; and Sally's house stands a little betore the house of Simpson. Some three months ago I overtouk Simpson on the turapike road, and I asked him if his cow were getting better, for his son had told me she had fallen sick. "She"s coming on surprisingly, Sir," quoth he. "The last time that the cow-doctor came to see her, 'Jem,' said he to me, looking earnestly at old Sally's house, 'Jem,' said he, 'mind and keep your cow-house door shut before the sun goes down, otherwise I won't answer what may happen to the cow:" 'Ay, ay, my lad," said I, "I understand your meaning; but I am up to the old slut, and I defy her to do me any harm now:" "And what has old Sally been doing to you, James :" said I. "Why, Sir," replied he, "we all know, too well, what she can do. She has long owed me a grudge; and my cor, which was in very good health, fell sick immediately after Sally had been seen to look in at the door of the cow-house, just as night was coming on. The cow grew worse and worse; and so I went and cut a bundle of wiggin (mountain-ash), and I nailed the branches all up and down the cow-house; and, Sir, jou may see them there if you will take the 
trouble to step in. I am a match for old Sally now, and she ca'nt do me any more harm, so long as the wiggin branches hang in the place where I have nailed them. My poor cow will get well in spite of her." Alas ! thought I to myself, as the deluded man was finishing his story, how much there is yet to be done in our part of the country by the schoolmaster of the nineteenth century!

NOTES ON THE HABITS OF THE WINDHOVER HAWK.

Nothisg can be more unfortunate for a man, than to bear a strong resemblance to another who is notorious for his evil deeds. The public eye marks him as he passes on, and tacitly condemns him for misdemeanors of which he is, probably, as innocent as the lamb which gambols on the lawn. This may be applied with great truth to the windhover hawk. He is perpetually confounded with the sparrowhawk, and too often doomed to suffer for the predatory attacks of that bird on the property of man. But, when your gun has brought the poor windhover to the ground, look, I pray you, into the contents of his stomach; you will find nothing there to show that his life ought to have been forfeited. On the contrary, the remnants of the beetle and the field mouse which will attract your notice, prove indisputably, that his visits to your farm have been of real service to it. 
This hawk has received the name of windhover on account of his custom of hovering in the air. By the way, he is not the only bird which performs this curious evolution. The sparrowhawk, the barnowl, the gull, and the kingfisher are often seen in a similar position.

A little attention on the part of the beholder would soon enable him to distinguish the windhover from the sparrowhawk. The windhover, when in quest of food, glides softly through the air, at a moderate height, now poised in the breeze on fluttering pinion, now resting in the void, apparently without motion; till, at last, down he comes, like a falling stone, upon the unconscious prey below. But, should he be disappointed in his purpose, he rises again in elegant ascent, to seek for food elsewhere. The sparrowhawk, on the contrary, though he will sometimes hover in the air, still he usuall secures his prey by means of a very quick pursuit. Both at early dawn and at the fall of night, he will dart past you with inconceivable velocity; and then woe betide the luckless victim that attracts his eagle eye. This bird often makes his appearance at a tower which I have built for the starlings, and to which above fifty pairs of these birds resort during the spring of the year. His unwelcome visit causes a tremendous uproar. A universal shriek of horror announces his detested presence; and scarcely have I time to fix my eyes upon the tower, ere the intruder is off with a starling in his talons.

Did the nurseryman, the farmer, and the country gentleman know the value of the windhover's ser- 
vices, they would vie with each other in offering him a safe retreat. He may be said to live almost entirely on mice; and mice, you know, are not the friends of man; for they bring desolation to the bee-hive, destruction to the pea-bed, and spoliation to the corn-stack. Add to this, they are extremely injurious to the planter of trees. The year 1815 was memorable, in this part of the county of York, for swarms of field-mice exceeding all belief. Some eight years before this, I had planted two acres of ground with oaks and larches in alternate rows. Scarcely any of the oaks put forth their buds in the spring of 1816; and, on my examining them, in order to learn the cause of their failure, I found the bark entirely gnawed away under the grass, quite close to the earth, whilst the grass itself, in all directions, was literally honeycombed with holes, which the mice had made. In addition to the bark of young oaks, mice are extremely fond of that of the holly tree: I have hollies which yet bear the marks of having been materially injured by the mice in winter. Apple trees, when placed in hedgerows, are often attacked by mice, and, in many cases, are much injured by them. I prize the services of the windhover hawk, which are manifest by the quantity of mice which he destroys; and I do all in my power to put this pretty bird on a good footing with the gamekeepers and sportsmen of our neighbourhood. Were this bird properly protected, it would repay our kindness with interest; and we should then have the windhover by day, and the 
owls by night, to thin the swarms of mice which overrun the land.

As the windhovers make no nest, they are reduced to the necessity of occupying, at second hand, that of another bird. I once made the experiment to try if a windhover would take possession of a nest newly built; and, in order to prepare the way, I singled out the nest of a carrion crow. As soon as the crow had laid lier third egg, I ascended the tree, and robbed the nest. In less than a week after this, a pair of windhovers took to it; and they reared a brood of young in its soft and woolly hollow.

The windhover is a social bird, and, unlike most other hawks, it seems fond of taking up its abode near the haunts of men. What heartfelt pleasure I often experience in watching the evolutions of this handsome little falcon! and with what content I see the crow and the magpie forming their own nests, as I know that, on the return of another spring, these very nests will afford shelter to the windhover. Were I to allow the crow and the magpie to be persecuted, there would be no chance for the windhover to rear its progeny here; for Nature has not taught this bird the art of making its nest in a tree. How astonishing, and how diversified, are the habits of birds! The windhover is never known to make use of a nest until it has been abandoned for good and all by the rightful owner; whilst, on the contrary, the cuckoo lays her egg in one of which the original framer still retains pessession.

The windhover usually lays five eggs, and one of 
them sometimes proves addle. This bird is seen to the greatest advantage during the time that it is occupied in rearing its young; at that period; nothing throughout the whole range of ornithological economy can surpass the elegance of its aërial evolutions.

Perhaps it is not generally known, that the windhover is a migratory bird; but, whether the greater part of these hawks leave England in the autumn, or merely retire from their breeding-place to some other part of our country, more congenial to their habits, is a problem which remains yet to be solved. For my own part I am of opinion, that a very large proportion of those which are bred in England leave it in the autumn, to join the vast flights of hawks which are seen to pass periodically over the Mediterranean Sea, on their way to Africa.

Last summer I visited twenty-four nests in my park, all with the windhover's eggs in then. The old birds and their young tarried here till the departure of the swallow, and then they disappeared. During the winter, there is scarcely a windhover to be found. Sometimes a pair or so, makes its appearance, but does not remain long. When February has set in, more of the windhovers are seen; and about the middle of the month their numbers have much increased. They may be then heard at all hours of the day; and he who loves to study nature in the fields may observe them, now on soaring wing, high above in the blue expanse of heaven; now hovering near the earth, ready to 
pounce upon the luckless mouse; and now inspecting the deserted nests of crows and magpies, in order to secure a commodious retreat, wherein to perform their approaching incubation. Allowing, on an average, four young ones to the nest, there must have been bred here ninety-six windhover hawks last summer: add the parent birds, and we shall have, in all, one hundred and forty-four. Scarcely five of these birds were seen here from Michaelmas to the latter end of January.

The periodical disappearance of the windhover from its breeding-place might give. rise to much ornithological enquiry; but I suspect that, when every circumstance shall have been duly weighed, we shall still be in the dark with regard to the true cause of its departure. The want of food cannot be supposed to force it away; for food the most congenial to its appetite is found here in great abundance at the very time when it deserts us. Neither can supposed inclemency of weatlier be alleged in support of its migration, as the temperature of England is remarkably mild long after the sun has descended into the southern hemisphere.

THE RUMPLESS FOWL.

$$
\text { Pauca meo gallo. Virgil. }
$$

Some time ago, I introduced this bird to the readers of Mr. Loudon's Magazine, in order to show them, that the feathers of birds are just as brilliant, and 
in as good condition, on the body of one which has no oil-gland, as on the body of one which is furnished with it. This being really the case, I drew the conclusion, that birds are not in the habit of anointing their plumage with the contents of their oil-gland.

The history of the rumpless fowl seems to be involved in much obscurity. Buffon tells us, that most of the hens and cocks of Virginia have no rump; and the inhabitants, he adds, affirm that, when these birds are imported, they soon lose the rump. Surely the inhabitants must mean that the progeny of the imported birds lose the rump. Monsieur Fournier assured the Count, that, when the rumpless fowl couples with the ordinary kind, a half-rumped sort is produced, with six feathers in the tail instead of twelve. Buffon tells us, that this bird is sometimes called the Persian fowl. Perhaps it may be more common in that eastern country than in France; still, after all, I find, upon investigation, that it is nothing more or less than a variety of the common barn-door fowl; and that it can be produced by a male and female, both of which are furnished with a rump, and of course with a tail.

Two years ago, in the village of Walton, a common barn-door hen, with a rump, laid eighteen eggs under a hedge which separates a little meadow from the highway. There was not a rumpless male fowl in all the village, or in the adjacent country. The mowers were cutting the grass just as the old hen was hatching her young. She was 
killed by a stroke of the scythe; and two chickens were all that could be saved from the wreck. One of the mowers conveyed the two young birds in his hat to the villager who had owned the hen, and whose house was hard by. She brought them up at the fire-side. They were male and female. The male was rumpless, and without a tail, whilst the female had a rump, and a tail of ordinary size.

When the former had become a full-grown fowl, I introduced to it a rumpless hen, by way of companion. She laid fourteen eggs, and sat upon them with great perseverance; but every egg proved addle. After this, she produced a dozen more in the course of the summer; and she sat upon them, but with no better success. I then substituted a male fowl with a tail, in lieu of her rumpless paramour; and they soon became a loving couple. She laid well the summer following, and sat twice; but her repeated efforts to produce a family were of no avail. During her last sitting, a Malay hen, of prying habits, took the opportunity of her momentary absence from the nest, and laid an egg in it. This produced a chicken, which the rumpless stepmother reared with maternal care.

It would appear, from these experiments, that the rumpless fowl is not prolific. But Cervantes tells us, that one swallow does not make summer. " Una golondrina, no hace verano." Wherefore further investigation is absolutely necessary, before the affair in question can be set at rest. However, the testimony which follows tends to prove that the rumpless fowl is fully capable of producing its race. 
There lives, in the village of Walton, an old woman notorious for rearing poultry. Her name is Nanny Ackroyd. Some few years ago, I had seen a pair of rumpless fowls feeding at her door. I called on Nanny the other day, and I asked her where she had procured the fowls; and if they had ever had a brood. She told me, that she had got them from the Isle of Wight; and that they had produced seven rumpless chickens, which she sold at the Market-cross, in Wakefield; but that she could not get the full price for them, as her customers did not fancy them, on account of their want of tail. On asking her what had become of the parent fowls, she said, that they both suddenly disappeared, a few weeks after she had sold the young ones, at the Market-cross, in Wakefield. Two or three unknown mendicants had been lurking in the outskirts of the village; and she was sure the vagabonds had nipped up her poor fowls.

My own rumpless fowl, mentioned above, came to an untimely end. He was at the keeper's house; and as the keeper had got a tame fox, I foresaw that some day or other, my bird would fall into its clutches. To prevent the impending catastrophe, I sent up one morning to the keeper, and desired that the fowl might be brought down to the hall in the evening. A giant Malay fowl espied it as soon as it had left its roost the next day; and, indignant at the appearance of such a rival-stranger on the island, he drove it headlong into the water, where it perished before assistance could be procured. 
But though its vital spark has fled for ever, still its outer form will remain here, probably for ages yet to come. I dissected it; and then I restored its form and features in a manner that may cause it to be taken for a living bird. This fowl now stands along-side of a common barn-door hen, which had assumed the plumage of a male, and whose fate has already been recounted in Mr. Loudon's $M a$ gazine of Natural History. She has been furnished by nature with an oil-gland, and a handsome tail; he has been deprived by nature of both these appendages. Still, his feathers are as glossy, and in as high condition, as those of his companion. I consider this fact as conclusive evidence against the received opinion, that birds make use of the contents of the oil-gland, in order to lubricate their feathers. If they really did make use of it, the state of the plumage on one of these birds ought to bear marks of its application.

Before I can be convinced that birds lubricate their feathers, I must require him, who inspects these two fowls (with a magnifying glass, if he chooses), to point out to me a difference in the plumage of the bird with an oil-gland, from that of the bird without one. When he shall have done this, I will yield, and willingly confess, that a close attention to this subject, for a very long time, has availed me nothing, and has only been the means of leading me into an evident error. 


\section{THE RAVEN.}

Sæpe sinistra cavâ prædixit ab ilice cornix.

Virg.

IT is now about three and twenty years since the last raven which frequented this neighbourhood either lost its life for supposed offences against the game-laws, or found it expedient to retire to some distant part, where it could live unmolested, and rear its brood in safety. Not far from hence, in the middle of a wood, there was a large oak tree, the bole of which, by its thickness and its towering height, had set every idling boy at defiance, time out of mind. On a huge limb of this giant son of earth, a pair of ravens annually renewed their nest, and reared a brood of young. At last, in evil hour, a restless village cobbler got a scheme into his head to plunder the establishment; and he forthwith engaged the blacksmith to make him some iron spikes, which were to be affixed to his feet, in order to facilitate his ascent into the tree. With this provision, one Sunday morning, of all other days in the week, the ragged rascal bent his unhallowed steps towards the tree which contained the raven's nest. By means of the spikes, he was enabled to overcome the difficulties hitherto deemed insurmountable, by every passing vagabond, who had cast a longing eye upon the treasure which was lodged in the tree. He mounted aloft, and robbed the nest of its young. From that unlucky day, the ravens were never seen to alight again upon their once favourite tree. But they still lingered in the neigl-- 
bourhood; and as they approached the eastern hill, which forms one side of this valley, I could hear their hoarse and hollow croaking long before I could see the birds themselves.

How different are the habits of the rooks, with regard to their place of incubation! You may plunder their nest annually, and annually they will return to it, and perform their incubation in it. So will the starling, and the jackdaw. But the carrion crow abandons her nest for ever, after the breeding season; no matter whether it has been plundered or not. It may here be remarked, that the rook, the starling, and the jackdaw, are always gregarious ; the raven and the carrion crow solitary birds most parts of the year.

Some few years after the ravens had been plundered by the cobbler, either the same couple, or a stranger pair, built their nest in an oak of moderate size, within a few yards of an ornamental sheet of water, and about two miles distant from the wood to which they had resorted in better times. The gentleman's gamekeeper, like all others of that sanguinary set, was on the look-out; and on seeing the nest, he fancied that he had discovered a den of thieves, who had settled there to pilfer poultry, and to worry his master's hares and pheasants by the dozen. The poor female was shot down dead to the ground; but, fortunately, the male escaped assassination. He tarried for a day or two in the environs, and then deserted us for ever. From the day of his disappearance, I have never seen or heard a wild raven in this part of the country; and times 
are now so changed for the worse, that I despair of ever seeing again this fine British bird in any of our woods.

He who wishes to study the habits of the raven in its own native haunts, must not look for him here. He must bend his steps to those parts of Yorkshire where the bird is still allowed to exist.

There is a brood of ravens every season on the rocks near Flamborough Head; and, no doubt, others are to be found, at certain intervals, along the vast extent of that bold and rock-bound shore. The nest is chiefly made of the same materials as that of the carrion crow, with the addition of a few dried weeds which grow on the coast. I have never. taken the eggs, but if I may judge from one in my possession, the egg is remarkably small for the size of the bird; and in colour, it bears a close resemblance to the egg of the carrion crow. The young, like those of all the pie tribe, are hatched blind. On leaving the nest, their feathers have a brownish cast; but after the first moulting, the birds acquire that glossy richness of plumage which is so conspicuous in the raven.

Though the naturalist will feel but little interest in the habits of a bird which is brought up as a pet, under the immediate inspection of man ; still I cannot help remarking here, that of all known birds (the grey red-tailed parrot of Africa not excepted), there is none to be found so docile, so clever, and so amusing as the raven. I bought a young one, about three years ago, at the well-known village of Flamborough, and I called it Marco. Marco could do 
every thing. He was as playful as a kitten; he showed vast aptitude in learning to talk; and he was so correct an imitator of sounds, that I had every hope of teaching him the tune, which Goldsmith informs us he heard a raven sing, with "great distinctness, truth, and humour." Marco was fond of seeing a carriage approach the house. He would attend company on their arrival at the bridge, and wait near the gate until their return; and then he would go part of the way back with them. He was an universal favourite, notwithstanding that at times his evil genius prompted him to commit almost unpardonable excesses; so much so, that I often said to him in the words of the poet,-

“Difficilis,_ facilis, jucundus acerbus es idem."

" In all thy humours, whether grave or mellow, Thou art such a touchy, testy, pleasant fellow; Hast so much wit, and mirth, and glee about thee, There is no living with thee, nor without thee."

One day, he took a sudden dislike to an old duck, with which, till then, he had been upon the best of terms; and he killed her in an instant. The coachman and Marco were inseparable companions; but at last they had a serious and a fatal quarrel. Marco bit him severely in the thumb; upon which, this ferocious son of the whip seized the bird by the throat, and deliberately strangled it. I learned from poor Marco, that birds will occasionally do that which I had always supposed to be solely confined to quadrupeds. When Marco could find a heap of sand, or when there was snow upon the 
ground, he would throw himself on his back, and rub himself on the sand or snow, just as dogs are wont to do, when they fall in with carrion.

No bird in the creation exhibits finer symmetry than the raven. His beautiful proportions, and his glossy plumage, are calculated to strike the eye of every beholder with admiration. He is by far the largest of all the pie tribe in Europe ; and, according to our notion of things, no bird can be better provided with the means of making his way through the world; for his armour is solid, his spirit unconquerable, and his strength surprising.

Necromancers of old were noted for their attention to the movements of the raven; and they are said to have counted no less than sixty-five different inflexions of his voice. His sable robe and hollow croaking seem to have rendered him of vast importance in those days; when old women were known to travel through the air on broom-staffs, and when the destiny of man was frequently foretold by the flight of birds. Nay, in our own times, the raven has not quite lost all claim to the knowledge of things to come; for good farmer Muckdrag's wife, whilst jogging on with eggs to market, knew that there was mischief brewing as soon as she had heard a raven croak on the unlucky side of the road.

"'That raven on the left hand oak,

Curse on his ill betiding croak,

Bodes me no good."

She had scarcely uttered this, when down came her 
old stumbling mare to the ground. Her every egg was smashed to atoms; and whilst she lay sprawling on the ruins of her oological speculation, she was perfectly convinced, in her own mind, that the raven had clearly foreseen her irreparable misadventure.

Our royal sovereign, good King Arthur of ancient days, was known to have passed into the body of a raven. Cervantes tells us of a tradition, current through the whole of Great Britain, that this muchbeloved monarch was changed into a raven by the art of witchcraft; and that, in the due course of time, he would be again in possession of his crown and sceptre. I don't care how soon. Cervantes adds, that from the day on which the change took place, no Englishman has ever been known to kill a raven, and that the whole British nation is momently expecting its king's return. I should like to see King Arthur's face, when his loving subjects tell him of our national debt, and show him the civil list. Methinks his long-lost Majesty will groan in spirit, when he learns that the first was a present from Dutch William, and the second a donation to the country by the cormorant-traitors who had driven away our last Catholic king, because he had proclaimed universal liberty of conscience, and had begun to question their right to the stolen property.

The ancients were of opinion that the raven lived to an extreme old age. I do not exactly see how the longevity can be proved, whilst the bird roves at liberty from place to place, far beyond the reach of man; and, indeed, the difficulty of proof is noways diminished when the raven is brought up tame 
in civilised society, for its perpetual bickerings with stranger dogs, and its incautious approach to the heels of vicious horses, seldom fail, sooner or later, to bring it to an untimely end. Still, I should be the last man in the world to question the veracity of remote antiquity, upon the mere strength of hasty surmise. Those who are gone before us, may possibly have had better opportunities of ascertaining the longevity of birds, than any which we now possess.

I never tire with reading the old fables in which birds are introduced. Notwithstanding the impossibilities and absurdities which are manifest in those rich effusions of ancient wit and humour; still I can always find much in them to convince me, that the writers of the olden times were no strangers to the real habits of birds. Ovid, who flourished some two thousand years ago, tells of a remarkably old raven. It might indeed have been a companion for Methusalem himself. When Medea, that wicked, wanton, wandering witch, had made up her mind to restore her aged father to the bloom of youtl, (which was contrary to the order of the Fates,) she boiled a pot of herbs, and threw into it the bones and carcass of an owl, together with a few slices of wolf's flesh, and the shell and inside of a fresh water-turtle. To these she added the beak and head of a raven, above nine hundred years old.

"Quibus insuper addit

Ora, caputque, novem cornicis sæcula passæ."

Thrice she soused her father over head in water, 
and thrice she held him to the fire, and thrice she rubbed him well with brimstone.

"Terque senem flammâ, ter aquâ, ter sulphure lustrat."

She then applied her lancet to his jugular, and having let out all the old man's blood, slie replaced it with broth made from the ingredients which she had stewed down for the operation. This did the job, and up jumped her father Eson a spruce dashing young fellow in the prime of life, with a fine black beard in lieu of a white one. N.B. From this operation we might surmise, that transfusion of blood in surgery is no modern invention.

Pity it is that the raven, a bird of such note and consequence in times gone by, should be exposed to unrelenting persecution, in our own days of professed philanthropy. His noble aspect, his aerial evolutions, and his wonderful modulations of voice, all contribute to render him an ornament to any gentleman's park. He can scarcely be styled a bird of rapine, in the strict sense of the word; for, in the few inland parts of this country where he is still protected, we hear of no very alarming acts of depredation on his part. A stray chicken or so, during the time that he is obliged to feed his young, - a rickety lamb which would never make mutton, - a leveret started from her seat by the village mole-catcher, make up nearly the whole amount of the raven's plunder. For my own part I would freely give him these; ay, and a dozen pheasants annually to boot, if he would but visit us again, and once more attempt to take up a permanent abode amongst us. 
APPLE TREES.

"Inutilesque falce ramos amputans Feliciores inserit."

Horace.

Maxy a time have I helped to cut away the branches of decaying apple trees, and to insert healthy grafts in their places; hoping to restore the tree to the sound and fertile state in which it once had been. Revolving seasons did but tend to show that I had completely lost my time; for the American bug, supposed to have been unknown formerly, in this country, attacked my labours in such formidable array, that nothing could withstand its fury.

Every lover of the orchard must have observed this white pestilence in the enclosures sacred to Pomona. It is seen on the branches and on the bole of the apple tree in the month of June, when it gives them the appearance of being dotted over with little patches of a downy white.

Long ago I turned my thoughts to the extermination of the spoliator, which had nearly rendered the choicest parts of the orchard a sickly, sad, unprofitable waste.

I began by trying to make the branches, upon which these diminutive harpies had settled, as disagreeable to them as it were possible, hoping by this manœuvre to starve them out of house and home. With this in view, I applied unctuous preparations to the injured parts of the trees; but finding, in the long run, that this availed me nothing, I made a decoction from walnut leaves, and washed the branches well 
with it, calculating that the bitterness of the decoction would render the favourite food of the insects unpalatable to them. But I was deceived: the bugs continued their depredations as though no pains had been taken to dislodge them.

The application of spirit of turpentine killed them at once, and for a few days after it had been applied I was in hopes that their extermination had been effected; but others soon appeared.

Despairing of success, I was on the point of quitting the field, and leaving the bugs in undisturbed possession of it; when I began to conjecture that I had not gone the right way to work. I reflected, that none of my applications could have penetrated sufficiently deep into the curved and knotty sinuosities of the diseased parts; and that, on this account, there would be a sufficient force of the enemy left alive to recommence its depredations at the first favourable opportunity. Wherefore I concluded, that nothing short of the entire destruction of the eggs, the young, and the adult, could save the trees from ultimate ruin. Knowing that the bug could not exist if totally deprived of air, I resolved to bury it alive; and this I effected by an application at once the most easy and simple that can be imagined. It costs nothing.

I mixed clay with water, till it was of a consistency that it could be put on to the injured parts of the tree, either with a mason's trowel, or with a painter's brush. I then applied it to the diseased places of the tree, and it soon smothered every bug. A second coat upon the first filled up every crack 
which showed itself when the clay had become dry: and this resisted for a sufficient length of time the effects both of sun and rain. The sickly parts, now effectually freed from the enemy which had been preying on their vitals, were placed in a state to be cured by the healing process of nature; and that nature has done her duty, my apple trees amply testify.

Probably this nostrum is too simple, and not sufficiently costly, for me to expect that it will attract much notice. Still I think there is no harm in committing it to paper. It may yet prove the best friend to the cultivator of apples, when all his more scientific and expensive resources shall have failed in their effect. I may say of it, what was said of a certain book of medicine in the olden time :-

- "Venena

Enecat, morbos fugat, atque sanos

Protegit artus."

\section{THE CHAFFINCH.}

" The thrushes chatter'd with affright, The nightingales abhorr'd his sight; And every beast before him ran, To shun the hateful sight of man."

Gay.

TIME was when the pretty denizens of air had no friend to encourage them to settle in this part of 
the country. They were slain without pity, or were chased away by every intruding gunner who took pleasure in pursuing them; and whose heart never throbbed at the sight of the poor bleeding bird which lay dead at his feet.

Thus the melody cf the vernal thrush, and the plaintive notes of the ring-dove, scarcely ever announced to us the arrival of that interesting time of the year when Nature awakes from her long and dreary sleep of winter. These sweet choristers of the grove were said to do mischief in the orchard, and in the kitchen garden; and this was a sufficient pretext to place them in no other light than that of common outlaws, to be punished with death whenever an opportunity should offer.

The little chaffinch, too, was to have no favour shown to him. He was known to haunt the beds of early radishes: and he would have done a deal of damage there, forsooth, had not our gardener luckily been allowed the use of a gun, with which lıe managed to kill, or to drive away, every chaffinch, thrush, and blackbird, that arrived within the precinct of his horticultural domain.

But this promiscuous slaughter has ceased at last. Every bird, be his qualities bad or good, is now welcome here; and still nothing seems to go wrong, either in the orchard, or in the garden. Neither does the protection afforded to them appear to act to my disadvantage in other quarters. The dovecot is most productive, notwithstanding that a colony of starlings (those pests to all dovecots in the eyes of farmers) exists within a stone's throw of it. The 
pheasants are crowing in every wood around; nor do the hoarse croakings of the carrion crows, or the frequent chatterings of the magpies, cause me any apprehensions that there will be a deficiency in the usual supply of game.

The chief way to encourage birds is to forbid the use of fire-arms in the place of their resort. I have done so here; and to this precaution I chiefly owe my unparalleled success. We have a tame magpie in the stable yard. It is the same bird that is mentioned in the paper on the stormcock, p. 254. Being one of the tribe whose plumage in the nest has the colours of that in after life, you cannot decide whether it is a male or a female. However, it has paired with a wild one; and although the wariness of the magpie is proverbial, nevertheless this strange bird will actually come and feed within a few yards of us, without betraying any symptoms of fear.

For these two years, a Canada goose and gander, attracted hither by the quiet which this place affords, have made their nest on a little island of alder trees. Although the female has laid five eggs each year, still there has been no brood. The gander seems to have been aware that something was going on wrong in his establishment, for this spring the old gentleman has taken care to introduce an extra female. Were Ovid, that excellent ornithologist, now on earth, he would tell us that this he-goose, dissatisfied with our law of monogamy, has been as far as Constantinople to buy a licence for a plurality of wives.

Amongst all the pretty warblers which flit from T 4 
bush to bush before me, as I wander through the flowery fields, next to poor cock robin, the cliaffinch is my favourite bird. I see him almost at every step. He is in the fruit and forest trees, and in the lowly hawthorn : he is on the housetop, and on the ground close to your feet. You may observe him on the stack-bar, and on the dunghill; on the king's highway, in the fallow field, in the meadow, in the pasture, and by the margin of the stream.

If his little pilferings on the beds of early radishes alarm you for the return of the kitchen garden, think, I pray you, how many thousands of seeds he consumes, which otherwise would be carried by the wind into your choicest quarters of cultivation, and would spring up there, most sadly to your cost. Think again of his continual services at your barn door, where he lives throughout the winter, chiefly on the unprofitable seeds, which would cause you endless trouble were they allowed to lie in the straw, and to be carried out with it into the land, on the approach of spring.

His nest is a paragon of perfection. He attaches lichen to the outside of it, by means of the spider's slender web. In the year 1805, when I was on a plantation in Guiana, I saw the humming bird making use of the spider's web in its nidification; and then the thought struck me that our chaffinch might probably make use of it too. On my return to Europe, I watched a chaffinch busy at its nest : it left it, and flew to an old wall, took a cobweb from it, then conveyed it to its nest, and interwove it. with the lichen on the outside of it. Four or five 
eggs, are the usual number which the chaffinch's nest contains : and sometimes only three. The thorn, and most of the evergreen shrubs, the sprouts on the boles of forest trees, the woodbine, the whin, the wild rose, and occasionally the bramble, are this bird's favourite places for nidification. Like all its congeners, it never covers its eggs on retiring from the nest, for its young are hatched blind.

There is something peculiarly pleasing to me in the song of this bird. Perhaps association of ideas may add a trifle to the value of its melody; for when I hear the first note of the chaffinch, I know that winter is on the eve of his departure, and that sunshine and fine weather are not far off. His first song tells me, that in a day or two more we shall hear the cooing of the ring-dove, and see it rise and fall in the air, as it flies from grove to grove, and that this pretty pigeon, so shy and wary during the winter, will in a day or two more allow me to approach within ten paces of it, as it feeds on the new springing verdure of the lawn.

Say, ye learned in ornithology, say, what is it that causes this astonishing change in the habits of the ring-dove; and forces it, I may say, to come close to our dwellings, and to coo incessantly from early February into late October; and then to shun our society abruptly, as though we had never befriended it at all?

The chaffinch never sings when on the wing; but it warbles incessantly on the trees, and on the hedge rows, from the early part of February to the second week in July; and then (if the bird be in a state of 
freedom) its song entirely ceases. You may hear the thrush, the lark, the robin, and the wren, sing from time to time in the dreary months of winter; but you will never, by any chance, have one single note of melody from the chaffinch. Its powers of song have surk into a deep and long lasting trance, not to be roused by any casualty whatever. All that remains of its voice, lately so sweet and so exhilirating, is the shrill and well-known monotonous call, which becomes remarkably distinct and frequent whenever the cat, the owl, the weasel, or the fox, are seen to be on the move.

We are told that in the winter season, the female chaffinches separate from the males, and migrate into distant countries. I have not been able to ascertain that so ungallant a divorce takes place in this part of the country. The chaffinclies assemble here with their congeners during the period of frost and snow, and you may count amongst them as many females as males.

Sad and mournful is the fate which awaits this harmless songster in Belgium and in Holland, and and in other kingdoms of the continent. In your visit to the towns in these countries, you see it outside the window, a lonely prisoner in a wooden cage, which is scarcely large enough to allow it to turn round upon its perch. It no longer enjoys the light of day. Its eyes have been seared with a redhot iron, in order to increase its powers of song, which, unfortunately for the cause of humanity, are supposed to be heightened and prolonged far beyond their ordinary duration by this barbarous process. 
Poor chaffinches, poor choristers, poor little sufferers! My heart aches as I pass along the streets, and listen to your plaintive notes. At all hours of the day we may hear these hapless captives singing (as far as we can judge) in apparent ecstasy. I would fain hope that these pretty prisoners, so woebegone, and so steeped in sorrow, to the eye of him who knows their sad story, may have no recollection of those days when they poured forth their wild notes in the woods, fiee as air, "the happiest of the happy." Did they remember the hour when the hand of man so cruelly deprived them both of liberty and eyesight, we should say that they would pine in anguish, and sink down at last, a certain prey to grief and melancholy. At Aix la Chapelle may be seen a dozen or fourteen of these blind songsters, hung out in cages at a public house, not far from the cathedral. They sing incessantly, for months after those in liberty have ceased to warble; and they seem to vie with each other, which can carol in the loudest strain. There is something in song so closely connected with the overflowings of a joyous heart, that when we hear it, we immediately fancy we can see both mirth and pleasure joining in the party. Would, indeed, that both of these were the constant attendants on this much to be pitied group of captive choristers! How the song of birds is involved in mystery! mystery probably never to be explained. Whilst sauntering up and down the Continent in the blooming month of May, we hear the frequent warbling of the chaffinch; and then we fancy that he is singing solely to be- 
guile the incubation of his female, sitting on her nest in a bush close at hand. But on returning to the town, we notice another little chaffinch, often in some wretched alley, a prisoner with the loss of both its eyes, and singing nevertheless as though its little throat would burst. Does this blind captive pour forth its melody in order to soothe its sorrows? Has Omnipotence kindly endowed the chaffinch with vocal faculties, which at one time may be employed to support it in distress, and at another time to add to its social enjoyments? What answer shall we make? We know not what to say. But be it as it will, I would not put out the eyes of the poor chaffinch, though by doing so I might render its melody ten times sweeter than that of the sweet nightingale itself. $\mathrm{O}$ that the Potentate, in whose dominions this little bird is doomed to such a cruel fate, would pass an edict to forbid the perpetration of the barbarous deed! Then would I exclaim, $O$ king of men, thy act is worthy of a royal heart. "That kind Being, who is a friend to the friendless, shall recompense thee for this."

\section{A SHORT REMARK OR TWO ON WHAT IS COMMONLY CALLED DRY ROT.}

Dry Rot is a misnomer. This disease in timber ought to be designated, a decomposition of wood by its own internal juices, which have become vitiated for want of a free circulation of air. 
If you rear a piece of timber, newly cut down, in an upright position in the open air, it will last for ages. Put another piece of the same tree into a ship, or into a house, where there is no access to the fresh air, and ere long it will be decomposed.

But, should you have painted the piece of wood which you placed in an upright position, it will not last long; because, the paint having stopped up its pores, the incarcerated juices have become vitiated, and have caused the wood to rot. Nine times in ten, wood is painted too soon. The upright unpainted posts, in the houses of our ancestors, though exposed to the heats of summer, and the blasts of winter, have lasted for centuries; because the pores of the wood were not closed by any external application of tar or paint : and thus the juices had an opportunity of drying up gradually.

In 1827, on making some alterations in a passage, I put down and painted a new plinth, made of the best, and, apparently, well.seasoned, foreign deal. The stone wall was faced with wood and laths; and the plaster was so well worked in the plinth, that it might be said to have been air-tight. In about four months, a yellow fungus was perceived to ooze out betwixt the bottom of the plinth and the flags; and on taking up the plinth, both it, and the laths, and the ends of the upright pieces of wood to which the laths had been nailed, were found in as complete a state of decomposition as though they had been buried in a hotbed. Part of these materials exhibited the appearance of what is usually called dry rot; and part was still moist, with fungus on it, 
sending forth a very disagreeable odour. A new plinth was immediately put down; and holes $1 \frac{1}{2}$ in. in diameter, at every yard, were bored through it. This admitted a free circulation of air; and to this day the wood is as sound and good as the day on which it was first put down. The same year, I reared up, in the end of a neglected and notoriously damp barn, a lot of newly felled larch poles; and I placed another lot of larch poles against the wall on the outside of the same barn. These are now good and well seasoned: those within became tainted, the first year, with what is called dry rot, and were used for firewood.

If, then, you admit a free circulation of air to the timber which is used in a house (no difficult matter), and abstain from painting that timber till it be perfectly seasoned, you will never suffer from what is called dry rot. And if the naval architect, by means of air-holes in the gunwale of a vessel (which might be closed in bad weather), could admit a free circulation of air to the timbers; and if he could, also, abstain from painting, or doing with turpentine, \&c., the outer parts of the vessel, till the wood had become sufficiently seasoned, he would not have to complain of dry rot. I am of opinion, that, if a vessel were to make three or four voyages before it is painted, or done with turpentine, $\&$ c., its outer wood would suffer much less from the influence of the weather than it usually suffers from its own internal juices, which cannot get vent, on account of artificial applications to the pores. But still the timber would be subject to the depredation 
of the insect. To prevent this effectually, Mr. Kyan's process must absolutely be adopted; and it must also be adopted to secure wood from what is called dry rot, in places where a free circulation of air cannot be introduced. I consider Mr. Kyan's process perfectly unexceptionable. The long arrows which the Indians use in Guiana are very subject to be eaten by the worm. In 1812, I applied the solution of corrosive sublimate to a large quantity of these arrows. At this hour they are perfectly sound, and show no appearance that the worm has ever tried to feed upon them.

I have penned down these transient remarks by way of preface to others, which I may possibly write, at some future time, on decay in living trees.

\section{HINTS TO ORNITHOLOGISTS.}

Most men have some favourite pursuit - some well-trained hobby, which they have ridden from the days of their youth. Mine is ornithology; and when the vexations of the world have broken in upon me, I mount it, and go away for an hour or two, amongst the birds of the valley; and I seldom fail to return with better feelings than when $I$ first set out. He who has made it his study to become acquainted with the habits of the feathered tribes, will be able to understand their various movements almost as well as though they had actually related their own adventures to him. 
Thus, when I see the windhover hawk, hanging in the air on fluttering wing, although it be at broad noon-day, I am quite certain that there is a mouse below, just on the point of leaving its hole for a short excursion: and then I thank him kindly, for his many services to the gardener and the husbandman; and I tell him, that he shall always have a firiend and a protector in me. Again, when I observe the carrion crow, in the month of May, sailing over the meadows with the sagacity of a spaniel; I know at once, that, somewhere or other, she has a nest of hungry little ones to provide for ; and that she is on the look-out for eggs, or for young birds, to supply their wants: and then I tell her I feel sorry from my heart, that the pressing duty of providing for a large and ravenous family should expose her to the eternal enmity of man; knowing full well that, at other seasons of the year, she is a real benefactress to him, by clearing his fields of a world of insects, which feed upon their produce.

For reasons unknown to us, the birds are particularly vociferous, both at early dawn, and at the fall of night. But when $I$ hear the partridge uttering its well-known call in the middle of the day, I comprehend at once, that it either sees bad company close at hand, in the shape of cats or weasels, or that its brood has been surprised and dispersed by some intruder; and that the individuals of the covey are then calling to each other, from the place of their retreat, in order that they may all meet again in some more secure and more sheltered quarter. 
This knowledge of the habits of birds, which at once lets you into their little secrets, is only to be obtained by a constant attention to the notes and the habits of the feathered tribes in the open air. It can never be learned in the solitude of the closet. Those naturalists who pass nearly the whole of their time in their study have it not in their power to produce a work of real merit. On the contrary, it too often happens that they do (most unintentionally, no doubt) a great deal of harm to science. Travellers, and now and then a foreigner, come to them, and desire that they will revise, or concoct, or prepare a work for the press. They comply with the request. But, having little or no knowledge themselves of the real habits of birds, they do not perceive the numberless faults in the pages which they are requested to prepare for the public eye. Hence it is that errors innumerable stare us in the face, when we open books which profess to treat on the nature and the habits of birds.

What a world we live in I say I, when I read t'rat turkey-cocks will break all the eggs of the females, for the purpose of protracting their future frolics; and that another species of bird flies away from the nest, when the egg is hatched, in order to procure food for the young one.

I tremble for the welfare of ornithology, when I am informed that the ornithologist, now-a-days, is not expected to climb lofty trees and precipices, in order to ascertain whether the birds which fre- 
quent them are in the habit of fabricating their own nests, or of using a natural cavity.

We are gravely told it cannot be expected that field ornithologists should risk life and limb, in order to ascertain such points. This is melancholy doctrine, and he who is determined to follow it must be content to remain in ignorance.

I cannot admit that the mere art of preserving the skin of a bird is sufficient to answer every scientific purpose; and I disagree with him who will not allow the study of internal anatomy to be the basis of the zoological system.

We may measure the feet of preserved bird-skins with rule and compasses, and then draw the conclusion, from external appearances, that this foot, forsooth, is gifted by Nature for grasping, and that, for perching: but it will not do. Internal anatomy must be consulted. It alone can let us into the real secret, why all birds which frequent the trees can grasp a branch with the utmost facility, and sit securely there, without any fear of falling from it.

See the barn-door fowl walking before us! No sooner does it lift its foot from the ground, than the toes immediately bend inwards. From this natural tendency to contract we draw the conclusion, that a bird is in absolute security when it perches upon a branch. By means of this admirable provision of Nature, the little delicate golden-crested wren can brave the raging tempest, on the top of the loftiest tree, in as perfect safety as the largest. bird of the creation.

Nothing can be more illusory than an attempt 
to judge of a bird's powers of perching by an external admeasurement of its feet and claws. Our speculation is unprofitable, and our judgment is of no avail whatever; for, after we have laid our rule and compasses down upon the table, and have left the house to take a walk into the fields, with a full conviction that we have learned our lesson from the dried skin of a bird, we find that the habits of one bird are utterly at variance with those of another, although the proportional anatomy of their feet and claws be exactly the same. Thus, we observe the ring-dove sitting up aloft on the slender branches of the towering elm : but the dovecot pigeon is never to be seen in so elevated a situation. Still, the feet of these two birds are alike. Our pheasant will sleep both upon the ground, and upon the branch of a tree. But the partridge of England is never known to resort to the trees, although its toes differ in nothing but in size from the toes of the pheasant. It requires an effort in birds to keep their toes straight; and an effort in man to keep his fingers closed.

Thus, from the study of internal anatomy, we learn that man can never be safe upon the branch of a tree, except when he is awake; and that a bird is perfectly secure upon it, even in the profoundest. sleep.

The barn owl has been singled out as a specimen of pre-eminence in perching; and we are informed that, as it represents the insessorial or perching order, its powers of grasping ought to be more than ordinary. We consequently find, continues 
our informant, that one of the claws is serrated, to give the bird a firmer grasp than it would otherwise have.

Now, this serrated part of the claw happens to be so high upon the claw itself, that it cannot, by any chance, come in contact with the branch to which the bird has resorted; and, as for this owl's pre-eminent powers of grasping, I may remark, that it is seldom or ever seen upon a small branch. Nine times out of ten it will alight upon the thick parts of the tree, where it remains in a standing position; and it will fall asleep in that position, if not disturbed.

We shall never know why some birds prefer to sleep on the ground, and why others select the branch of a tree whereon to take their repose for the night. That the formation of the feet and toes has nothing to do with their choice appears evident from the different habits of the ring-dove and the common pigeon, the partridge and the pheasant.

By the way, though the pheasant will unite with our barn-door fowl, and produce a progeny, still there is a wonderful difference in the habits of these two birds. The pheasant crows before it shakes or claps its wings; the barn-door fowl, after. The pheasant never claps or shakes its wings except in the breeding season, and when it is on the ground; but the barn-door fowl will clap its wings, either on the ground or on the roost, at all times of the year.

Should our grave doctors of zoology decide that, by the study of external anatomy alıne, we can be 
enabled to point out those birds which are supposed to be pre-eminently gifted with the powers of perching and of grasping; and should these our masters recommend that this novel study be applied to quadrupeds, and to bipeds, as well as to birds; I respectfully beg leave to inform them that I have been gifted by Nature with vast powers of leg and toe: I can spread all my five toes; and, when I am barefoot in the forest, I can make use of them in picking up sundry small articles from the ground. Having an uncommon liking for high situations, I often mount to the top of a lofty tree, there to enjoy the surrounding scenery: nor can I be persuaded that I risk "life and limb " in gaining the elevated situation. These, no doubt, are qualities and propensities aberrant from the true human type; and, according to the new theory, will at once account for my inordinate love of arboreal celsitude.

There is a bird in Guiana named Kamichi. We call it the horned screamer. On its head grows a long, slender, and blunt kind of horn; if horn it can be called. We are informed, in a late publication, that the bird uses this horn as a means of selfdefence against its enemies.

La Mancha's knight, in his wildest mood for pike and helmet, never hit upon any thing so extravagant as this. No bird ever makes use of the crown of its head, or of anything that grows thereon, as a means of self-defence. Even if the horn on the head of the Kamichi were of a texture sufficiently strong to form a weapon of defence, still this bird 
would not want it; for it has tremendous spurs or its pinions, well adapted, and rightly placed, to punish an opponeut.

Were we to estimate the powers of walking in the coots by the outward appearance of their feet, we might inform the public that "they are such bad walkers that they appear to stagger in their gait, and that they walk with difficulty and unsteadiness." But when we see them on land, every day throughout the winter, feeding on grass with the wigeons, except in a great fall of snow, we have proof positive, by their aptitude at walking, and by their velocity in running, that our judgment has been rash, and that our theory is unsound.

We are informed that jays live more amongst trees than upon the ground; and the arboreal propensity of this bird is inferred from the shape of its toes. Now, let it be remembered, that, with the exception of the short periods when garden fruits and acorns are ripe, this bird must be upon the ground to procure a maintenance. Here, where he is protected, lie may be seen upon the ground at all hours of the day.

The common wagtail, too, is pronounced to be a " truly terrestrial bird," on account of the formation of his toes. Come hither, and you shall see the conmon wagtail in the daily habit of resorting to the trees.

Those who derive their knowledge of birds from the inspection of their external anatomy alone, may write on the use of bristles at the mouths of birds; and they may tell us that, in proportion as 
birds partake of a vegetable and an insect diet, so are these bristles more or less developed. But the fallacy of this theory is manifest in the ordinary habits of the barn-door fowl, the wigeon, and many other birds. During the summer months, the barndoor fowl, whilst cropping the grass and herbs, will capture, with the utmost facility and avidity, every insect, great or small, or soft or hard, which is unfortunate enough to be within its reach. The diet of the wigeon is grass. Still, neither the wigeon, nor the barn-door fowl, have bristles at the beak.

The claws of rapacious birds are pronounced to be "retractile." If they are so, then the knowledge of internal anatomy would force us to pronounce the claws of other tribes of birds, such as the robins, the doves, the barn-door fowls, and a thousand others, to be retractile.

The soldier must spend many a day amid the roar of hostile cannon, before he becomes qualified to command an army; the carpenter ought to work for years in the dock-yard, ere he attempts to build a line-of-battle ship; and the schoolmaster has to pore over many a scientific volume, in order to prepare himself to teach the matliematics.

But, somehow or other, it happens, now-a-days, that practical knowledge does not seem to be considered essentially necessary for those who undertake to write on certain parts of Natural History. Thus, some there are who will offer their history of birds to the public, although it can be ascertained that they have never been in the country which those birds inhabit. Others again, not 
having resided a sufficient length of time amongst the foreign birds which they undertake to describe, are perpetually giving statements at variance with the real habits of the birds. Thus the account which is given us of the habits of the Toucan is wrong at all points; to say nothing of its tongue, \&c. No man who has paid sufficient attention to the woodpeckers whilst in quest of food, will allow himself to be led away with the idea that these birds "break through and demolish the hardest wood."

Give me the man who, after minute examination, has written his account of birds in the country where the birds themselves are found. Give me the man, I don't care of what nation, who has published his ornithological investigations without having first placed them in the scientific hands of those men, who would fain persuade him that no work on ornithology can pass safely through the fiery ordeal of modern criticism, unless it has previously received the polish of their own incomparable varnish.

Thus, in days of yore, old Apollo advised his son Phaethon to let his face be well smeared with celestial ointment, in order to make it fireproof, ere he mounted on the box of the solar chariot.

" Tum pater ora sui, sacro medicamine, nati

Contigit, et rapidæ fecit patientia flammæ."

But, notwithstanding this precaution, the lad got himself into a sad broil; and we know not what disasters his folly might have brought upon the world, had not mother Earth bestirred herself, and persuaded Jupiter to stop his wild career. At her 
urgent entreaties, Jupiter felled him with a thunderbolt into the river $\mathrm{Po}$, where, I understand, he got pretty well cooled.

Would that we had a Jupiter here in England, with a birch rod in his hand, to tickle some of our zoological Phaethons! I would willingly act the part of mother Earth; and I would undertake to show, by sundry documents, which have reached me through the medium of the press, that, if they be allowed to drive their new-fashioned vehicles on our good old zodiac much longer, they will disfigure it in such a manner that, at last, we shall not be able to distinguish the Bull from the Ram, or the beautifully tapering fingers on the hand of the Virgin, from the rough and crooked claws which arm the shell-bound body of the Crab.

\section{ON MUSEUMS.}

These are the times for scientific discoveries. Till lately, we went fastest on a race-horse; but now we go faster still upon a rail. In our days, an Italian has put many thousand pounds of English money into his pocket, for imparting to Mr. Bull the important secret that we can have as good music with one fiddle-string as we formerly had with four. Witches can now go through the air without the aid of broom-staffs, by applying to Mrs. Graham, the aeronautess. A piece of stamped paper from Thread. needle Street is as eagerly sought after as the: 
purest gold of Peru. Vessels are now made to go both against wind and tide; a thing deemed utterly impossible in brave Commodore Trunnion's day. It was once indispensably necessary for Englishmen to wear tails (either club or pig) on the nape of the neck. Billy Pitt's discovery of the powder-tax has proved that we can do without them.

Amidst all these extraordinary movements and inventions, our museums alone seem to have stood stock still, with the most invincible pertinacity. I allude not to the mere buildings themselves: they, indeed, are ever on the change. Scarcely a year passes over our heads, but some new structure is raised by the votaries of natural history, with an outside of beautiful architecture, but with inner apartments destined to receive articles of old and execrable workmanship.

When I visit these magnificent buildings, in the different countries through which I pass, I can scarcely refrain from quoting the old verses:-

"The walls are thick, the servants thin, The Gods without, the devils within."

In every apartment dedicated to the arts and sciences, saving that of natural history, we find the materials in the inner places quite upon a par, and often vastly superior, to the outer workmanship of the building itself. Thus, he who dedicates a gallery to painting always takes care to have a show of pictures which will adorn the walls; and he who builds an ornamental library seldom fails to fill it with books far more costly and important than any- 
thing in the composition of the structure which he has raised for their reception. But, when a committee of gentlemen is chosen to form a museum, their attention to the outer parts of the building seems to know no bounds; whilst the ornamenting of the interior (which, by the way, ought to be considered as the very marrow and essence of the establishment) is left to pure chance. Thus, the members tell the public that they will be thankful for private donations. They often deposit specimens of their own in the museum; and authorise their curator to pick up what he can, at different public sales. The lavish expenditure on the outside of the temple, and parsimony with regard to the internal decorations, is giving, as it were, too much to the body, and too little to the soul.

Still, the directors do not ${ }^{\circ}$ see the thing in this light. They go jogging on in the old beaten path ; and I don't know whether it be very prudent in me to hint that it is high time for them both to digress, and to mend their pace. I am much more cautious now, than I used formerly to be in giving my opinion when I enter a museum. The burnt child generally dreads the fire.

Some years ago, curiosity led me to stray into a very spacious museum. As I passed through a kind of antechamber, I observed a huge mass of outstretched skin, which once had evidently been an elephant. I turned round to gaze at the "monstrum horrendum informe," when a person came up, and asked me what I thought of their elephant. "If," said I, "you will give me two cow-skins, with that 
of a calf in addition to them, I will engage to make you a better elephant." This unlucky and off-hand proposal was within an ace of getting me into trouble. The sages of the establishment took cognisance of it at one of their meetings; and somebody proposed that a written reprimand should be sent to me. However, a prudent voice in the assembly caused their wrath to subside, and smiles played once more over their hitherto benign countenances.

I have occasionally noticed the defective manner in which birds are stuffed for museums. At present, I will confine myself solely to quadrupeds; and, in my remarks on the very inferior way in which they are preserved, I beg to declare that I make no allusions whatever to any one museum in particular.

It may be said with great truth that, from Rome to Russia, and from Orkney to Africa, there is not to be found, in any cabinet of natural history, one single quadruped which has been stuffed, or prepared, or mounted (as the French term it), upon scientific principles. Hence, every specimen throughout the whole of them must be wrong at every point.

Horace, in giving instructions to poets, tells them how he would have different personages represented. Let Medea, says he, be savage and unconquerable; let Ino be in tears; let Ixion be perfidious ; let Io be vagrant; and let Orestes be in sorrow:-

"Sit Medea ferox invictaque, flebilis Ino, Perfidus Ixion, Io vaga, tristis Orestes."

Now, should I call upon any one of those, who have given to the public a mode of preserving specimens for museums, to step forward and show me how to 
restore majesty to the face of a lion's skin, ferocity to the tiger's countenance, innocence to that of the lamb, or sulkiness to that of the bull, he would not know which way to set to work : he would have no resources at hand to help him in the operation; he could not call to mind one idea which would enable him to restore the protuberance which is seen over the eye, or to give boldness to the front, or expression to the lips, or beauty to the cheeks, or, in fine, symmetry to the whole. He could produce nothing beyond a mere dried specimen, shrunk too much in this part, or too bloated in that; a mummy, a distortion, an hideous spectacle, a failure in every sense of the word.

But how comes it, that such clever and enterprising men, as those generally are who have the appointment of working-curators to museums, should never yet have discovered the true cause which has occasioned all their errors and mistakes? The answer is brief and easy. They have not gone the right way to work in their attempts to overcome the difficulties which stared them in the face. They seem not to have reflected sufficiently that the quadruped, before they skinned it, was of beautiful form, and of just proportions, and had that in its outward appearance which pleased the eye of every beholder; but that no sooner had they taken the skin off, than it had lost its beauty, and these fine proportions; and that the parts which still in some measure retained the appearance which they had in life would, in the course of a short time, contract and dry in, and put on a very shriveled and mummy- 
like appearance. Add to this that, in stuffing their animals, they have tried to effect by despatch what could only be done by a very slow process.

Thus, in order to prevent the skins from becoming putrid, especially in hot climates, it has always been a main object with these operators to get the skins dried as soon as possible. Again, finding the ${ }^{2}$ the skins wanted support, they have placed insidt of them a hard body of straw, or of tow, or some. times of wood, by way of a solid foundation, into which they might fix their wires. Such a process must effectually destroy every chance of success. The nose, and lips, and ears, \&c., of the specimen may look well for a few days after the operation; but, in the course of time, they will become so hideous, that every connoisseur will turn from them in disgust.

These remarks are just. Let us go and examine a stuffed monkey, for example, in any museum we choose. See! its once pouting lips are shrunk to parchment; its artificial eyes are starting from the sockets; its ears seem like the withered leaf of autumn; and its paws are quite gone to skin and bone. It is what it ought not to be : it is the product of a bad system, which ought to be exploded in these days of research and improvement. But how is this defective system to be improved, so that 2 specimen may be produced, which shall be right in all its parts, durable as the table on which it is placed, safe from the depredations of the moth, and not liable to injury when exposed to damp? To effect this, two things are indispensably necessary. The 
first is, to put the skin of the quadruped upon which you are going to operate in a state to resist putrefaction, and the attacks of the moth, without the use of that dangerous, and at the same time inefficient, composition, known by the name of arsenetical soap. The second is, to keep the skin moist during the time in which you are imparting to it the form and features which it is ultimately to retain.

These most necessary points are gained by immersing the skin in a solution of corrosive sublimate in alcohol; and afterwards, when you are in the act of restoring it to the proper form, by touching certain parts of it, such as the nose, lips, and orbits, with a mixture, one portion of which is salad oil, and the other three are spirit of turpentine.

Those who preserve quadrupeds for cabinets of natural history seem not to be aware that, after the skin of the animal has been taken off, there is a necessity for some parts of it to be pared down from within. These parts are chiefly the nose, the lips, and the soles of the feet. Unless they be rendered thin by the operation of the knife, there will be no possibility of restoring to them that natural appearance which they were seen to possess in life. The inner skin of the ears, too, must be separated from the outer one, until you come close to the extreme edges. Nothing short of this operation can save the ear from becoming a deformity.

Every bone in the skin, to the last joint of the toe, next the claw, must be taken out, in order to allow the operator an opportunity of restoring the skin to its former just proportions. 
The mouth must be sewed up from the inside (the skin being inside out when you sew it), beginning exactly in the front, and continuing the operation each way to the end of the gape. When the skin is taken out of the solution, it must be filled quite full of chaff or sawdust (but I prefer chaff), not minding whether the fur be wet or dry. When this has been done, the skin has almost the appearance of an inflated bag, quite deficient in feature and in muscular appearance. 'Rudis, indigestaque moles." It now depends upon the skill and anatomical knowledge of the operator (perhaps I ought to call him artist in this stage of the business), to do such complete justice to the skin before him, that, when a visiter shall gaze upon it afterwards, he will exclaim, " That animal is alive!" "Stare loco nescit, micat auribus, et tremit artus!"

There are now no obstacles, either from without or from within, to impede the artist's progress. The skin is perfectly free from all chance of putrefaction, is quite supple, and will remain so as long as required. There is no hard body inside to obstruct the transit of a working-iron ; there is not anything in the shape of wires to prevent him from lengthening or shortening the neck, body, thighs, and legs, according to his own judgment.

Now we proceed to support the skin in any attitude the artist may wish to place it in.

Join two pieces of wood in the shape of a carpenter's gimlet, and of size corresponding to the size of the animal. When you have nearly filled the abdomen with chaff, introduce this machine, and let 
the shank hang down outside of the skin, just as though it were a fifth leg in the centre of the body, equidistant from the fore and hind legs. This fifth leg, or what may be called the shank of the gimlet, is of any sufficient length, and is passed through a hole in the table before you, and then fastened with a couple of wedges. By this contrivance you can raise the animal as high as you wish, or you can lower it at your pleasure; and the feet will just touch the table, without requiring any wire inside to support them. I used formerly to put a stick into the skin by way of back-bone, with pieces of string tied to it at short intervals. These pieces of string were passed through the skin, just where the back-bone had been; and then they were attached to a gallows above, which gave an excellent support to the skin. But I now prefer the other process, as I find it more convenient.

Every thing is now ready for the artist to exer. cise his abilities.

With a piece of iron, from the size of a large darning-needle to that of a ramrod (or larger and thicker still if the bulk of the animal require it), and shaped at one end like a carpenter's pricker, he will push out every part of the skin which ought to be pushed out, and then reduce with the end of his finger any part that may be too prominent; having already made divers small holes in the skin with his penknife, in order to afford entrance to the workingiron. Thus, a small hole on the top of the head will enable him to reach the nose, upper lip, and cheeks ; another behind the root of each ear; another under 
the jaws; others, again, on the back, that he may reach the legs and remaining parts of the body. Under each foot there will also be a liole, to give him the opportunity of getting at the toes. The lips are by far the most difficult part to manage. The operator must have a working-iron in both hands. One of these will do the work within the head, and the other that without: for the lips require to be re-formed with a beautiful rotundity; and this can only be effected by means of the inner and the outer irons working in opposite directions. During the actual operation, the animal need not be kept in its original position. A smaller animal may be placed on the operator's lap: the larger may be thrown on the ground, or on the table. Every day the nose, and lips, and orbits ought to be touched with the oil and turpentine, in order to keep them moist. At first, after you have used the workingiron in every quarter where it is required, there will be no appearance of a re-formation of the features. Nevertheless, in the due course of time, as the skin stiffens, the artist will see the features gradually appear; and every day he will be more and more content with his work. At last, the skin will retain the slightest impression communicated to it by the touch of the working-iron. Thus the artist will have it fully in his power to reproduce wrinkles, or warts, or hollows, or a smooth surface, just as occasion may require.

The fur will be equally under his command. He will raise it, or depress it, according to circumstances, and it will retain the position ever after. Thus, a 
stuffed cat in anger will exhibit a tail of the same extraordinary bulk which it does when a dog threatens its existence.

All animals ought to be well washed in soap and water, with a hard brush, before they are skinned. This will have a surprising effect in beautifying the fur.

As there are parts of a quadruped's skin which are bound down, as it were, to the bone (at the eyes, for example), it will be necessary to pass a thread, with a sufficient knot at one end, through these parts, and to let the end without a knot hang loose after it has been drawn out at the opposite quarter. Thus, there must be a thread in the extremities at the gape of the mouth, and one at the corners of the eyes; and others in different parts of the body, according to the operator's judgment. By pulling these at the end which hangs out, he will be enabled to depress the parts into their natural shape.

The artificial eyes must be put in on the first day of the operation, and taken out and put back again every time the head of the specimen is modelled.

When all is completed, and the skin has become perfectly dry, the artist takes out the chaff or sawdust; and he finds that the specimen is quite firm enough to stand without any support from wires. He cuts three sides of a square hole under the feet, to let out the chaff; and when this is done he returns the skin to its place.

A slit must be made in the crown of the head, or under the jaws, to allow him to fix the artificial 
eyes with a little putty or wax. The slit, if properly done, will leave no mark on the fur.

If the quadruped be stuffed in distant countries, with an intention to be sent home, it may be cut up, when finished, into three or four separate pieces, and this will facilitate the carriage. When dividing it, the operator must take care to hold his knife so as to humour the angle which the fur forms with the skin. Thus, were $I$ to cut a preserved skin in two parts, the blade of my knife would point to the head, and the haft to the tail of the animal. By attention to this, not a liair of the fur will be cut during the operation.

I will just add here (although it be a digression), that there is no difficulty in making the legs and feet of eagles, turkeys, and other large birds, retain their natural size. You may go through every known museum, and you will find that the legs of these, and of all large birds, are dried and shrivelled, as though they belonged to the mummies of ancient days. In order to give the legs of birds a natural appearance, and a natural "size, the skin, from the very claws to the top of the leg, must be separated from the bone by running a working-iron betwixt it and the bone, and then modelling the skin with the working-iron.

The wattles of fowls, the caruncles of turkeys, and the combs of cocks, by the simple process of internal modelling, may be made to retain their natural size.

I have now given an outline of the mode of preserving quadrupeds upon scientific principles. Here, 
tnen, I stop; for I can go on no farther. I can no more explain, by the agency of my pen, how to make the thousand and one little touches which are necessary to insure success, than a fiddler can convey instructions by letter to one who has never used the bow. He may tell him, forsooth, to draw the horse-hair at right angles over the catgut ; and and he may add directions how the learner is to stop and shift, and stop and shift again, until he shall produce delightful music. But this will avail him nothing. The lad will scrape and scrape again, for want of personal instructions, till at last the man who is doomed to be punished by his grating will cry out, -

"Old Orpheus play'd so well, he moved Old Nick; But thou movest nothing but thy fiddle-stick."

I have turned this new discovery ten thousand times over in my mind, and I invariably come to the same conclusion; viz., that I cannot give sufficient instruction by means of the pen alone. I am placed in a situation somewhat like that of the French cook, who was ordered by his king to make a dish out of that which put his culinary powers utterly at defiance. "I have turned it every way, an't please your Majesty," said he; " and I have tried it with every kind of sauce ; but, positively, I cannot make a dish of it." Neither can I effect, through the medium of the pen, that which I could wish to do in this case. Wherefore, I beg to inform the reader that it requires the dissecting hand of the instructor, and from two to three weeks of actual work 
upon a specimen, to render the novice an adept in this new mode of preserving quadrupeds for cabinets of natural history. But, as I have neither leisure nor inclination to assemble pupils around me, I must request him who approves of the plan to be satisfied with the outline which I have just given him. I have no doubt but that his own abilities and industry will eventually crown his efforts with success.

Upon this new principle I have prepared the large ant-bear, a land tortoise, an armadillo, a dog's head (now in the possession of the Duke of Northumberland), a hedgehog, a polecat, and the nondescript.

These specimens will be amply sufficient to prove that animals with a rough coat of hair, others with a smooth one, others with a shell, others with a scaly armour, others with a soft fur, and others, in fine, with a skin studded over with spikes, can have their form and features restored; and that the skin, prepared after the manner which I have described, will always retain its shape and brilliancy, and be quite free from the ravages of the moth, or from any detriment by being exposed to damp.

Museums ought to be encouraged by every means possible. The buildings themselves are, in general, an ornament to the towns in which they have been built; whilst the zoological specimens which they contain, although prepared upon wrong principles, are, nevertheless, of great interest ; since they afford to thousands, who have not the means of leaving their own country, a frequent opportunity of seeing 
the rare and valuable productions which are found in far distant parts of the globe.

When I visit Leeds, I generally spend an hour in Calvert's Museum, where I never fail to be highly gratified. Mr. Calvert is a gun-maker of the first order. I am always lost in admiration when I cast my eyes on the vast collection of treasure which this lover of the arts has brought into the spacious and well-proportioned apartment, built at his own expense, and arranged after his own plan. In conversing with him on the habits of those animals which have come under his own immediate notice, I perceive something so true, so pertinent, and so straightforward in his observations, that I always feel regret when I see by my watch it is time for me to depart.

It has been remarked by some, who have conversed with me on this new process of preparing specimens for museums, that it would take up too much time. I am not aware that this would be the case; for he who is solely occupied in preparing specimens would always contrive to have several on hand at one and the same time. But, even granting that a great portion of his time were spent upon a single animal; is not one good specimen worth twenty bad ones? Who would fill his gallery full of Holland toys, when he has it in his power to place there statues of the first workmanship?

Indifferent specimens are admitted into museums only because better cannot be procured: and better will never be procured, until a radical change be 
made in that mode of preparation which is now in universal use.

I often think that the directors of public museums commit an error in not giving more encouragement, in a pecuniary point of view, to those whom they engage to prepare the specimens. The very moderate salary which these meritorious men receive is not a sufficient requital for their services. Moreover, the quantity of work which is required at their hands too often prevents them from trying experiments, which might probably prove of vast utility to the establishments under their inspection. Should this paper find its way across the water, and attract the notice of our Gallic neighbours, who are full of genius, and are remarkable for their perseverance, I do not despair to see a great alteration for the better at their magnificent establishment for natural history in the Jardin des Plantes, on my next visit to the French capital.

THE END. 





\section{University of Californla}

\section{SOUTHERN REGIONAL LIBRARY FACILITY}

305 De Neve Drive - Parking Lot 17 - Box 951388

LOS ANGELES, CALIFORNIA 90095-1388

Return this material to the library from which it was borrowed. 
A $001295387^{3}$ 


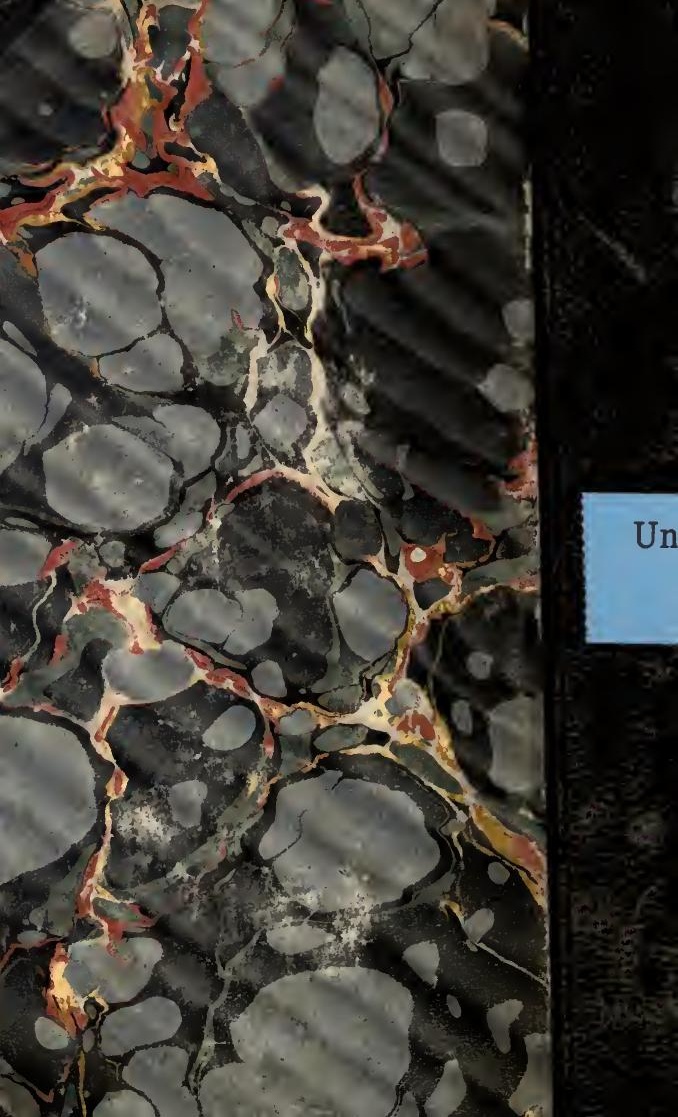

